Reference Publi-

cations

A 1101 777325

NBSIR 81-2445

\begin{tabular}{l} 
| $\begin{array}{l}\text { Brittle Materials At High } \\
\text { Temperatures }\end{array}$ \\
\hline
\end{tabular}

U.S. DEPARTMENT OF COMMERCE

National Bureau of Standards

National Measurement Laboratory

Center for Materials Science

Fracture and Deformation Division

Washington, DC 20234

December 1981

Final Report

NBS-DOE Interagency Agreement EA-77-A-01-6010

Prepared for

- зpartment of Energy

$-Q C \longrightarrow$ ssil Fuel Utilization Division

100 ashington, DC

.456

31-2445

1981 



\section{APPLICATION OF PROOF TESTING TO \\ BRITTLE MATERIALS AT HIGH \\ TEMPERATURES}

N. J. Tighe and S. M. Wiederhorn

U.S. DEPARTMENT OF COMMERCE

National Bureau of Standards

National Measurement Laboratory

Center for Materials Science

Fracture and Deformation Division

Washington, DC 20234

December 1981

Final Report

NBS-DOE Interagency Agreement EA-77-A-01-6010

Prepared for

Department of Energy

Fossil Fuel Utilization Division

Washington, DC

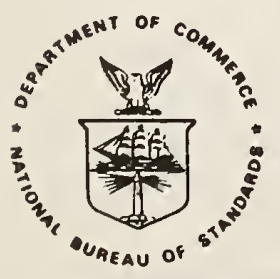

U.S. DEPARTMENT OF COMMERCE, Malcolm Baldrige, Secretary NATIONAL BUREAU OF STANDARDS, Ernest Ambler, Director 


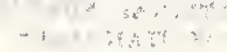

b. 


\section{Table of Contents}

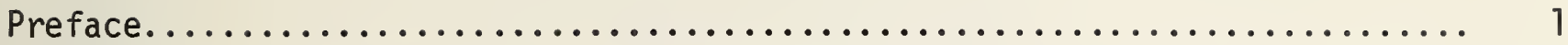

Proof Testing of Ceramics: I Experiment.......................... 2

Proof Testing of Ceramics: II Theory............................. 25

Application of Fracture Mechanics in Assuring

Against Fatigue Failure of Ceramic Components..................... 62

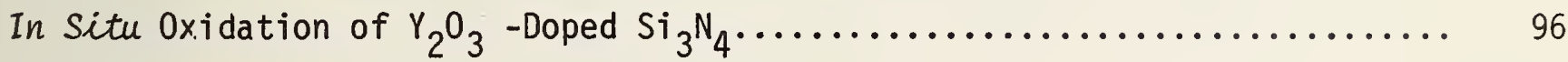

Effect of Strain Rate on the Fracture Toughness

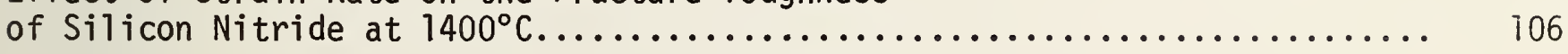

Fracture Strength and Weibuli Distribution of

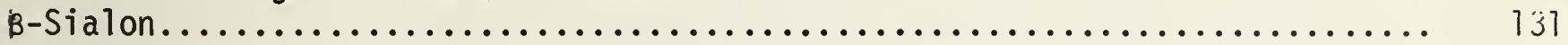

A Probabilistic Framework for Structural Design..................... 138

Effects of Exposure on the Reliability of Silicon Nitride............... 171

Effects of Oxidation on the Surface and Near-Surface

Structure of Silicon Nitride...................................... 195 



\section{Preface}

Papers pubiished or submitted for publication during the contract period of 0ctober 1978 to September 1981, are reproduced in this report. This is the final report on NBS-DOE, EA-77-A01-6010. The principal investigators were Sheldon M. Wiederhorn and Nancy J. Tighe. 
NBSIR 79-1934

PROOF TESTING OF CERAMICS:

I. EXPERIMENT

J.E. Ritter, Jr. and P.B. Oates

Mechanical Engineering Department University of Massachusetts

Amherst, MA 01003

E.R. Fuller, Jr. and S.M. Wiederhorn

National Bureau of Standards

Fracture and Deformation Division

National Measurement Laboratory

Center for Materials Science

National Bureau of Standards

Published in:

Journal of Materials Science

15, $2275-2281$ (1980) 


\section{PROOF TESTING OF CERAMICS: I. EXPERIMENT}

J.E. Ritter, Jr. and P.B. Oates Mechanical Engineering Department

University of Massachusetts

Amherst, MA. 01003

E.R. Futler, Jr. and S.M. Wiederhorn National Bureau of Standards

Washington, D.C. 20234

\section{ABSTRACT}

The effectiveness of proof testing as a method of improving component reliability was studied by comparing the inert strength distributions of soda-lime-silicate glass before and after proof testing. The effects of unloading rate from the proof stress, hold time at the proof stress, and proof-test environment were examined. The results indicate that the proof test must be conducted with rapid unloading rates and good environmental control to be effective. The theoretical implications of these results are discussed. 


\section{INTRODUCTION}

Proof testing is one means used to assure the mechanical reliability of structural ceramics. In proof testing, ceramic components are subjected to stresses that are greater than those expected in service in order to break the weak components and thus truncate the low end of the strength distribution. In this manner, weak components are eliminated before they can be placed in service. Proof testing has been applied to spacecraft windows, ${ }^{1,2}$ electrical porcelain insulators, ${ }^{3}$ and vitrified grinding wheers. 4

Wiederhorn, Evans, and Fuller ${ }^{5-7}$ have provided a mathematical foundation for the selection of the proof-test stress and the establishment of proof-test conditions. Their analys is is based on the assumption that failure of ceramics occurs from the growth of preexisting flaws. By characterizing this crack growth and coupling crack growth parameters with proof testing, they derived the strength after proof testing assuming flaw growth during the proof-stress, load-unload cycle. The resulting theory indicates that crack growth must be minimized to have effective proof testing. This can be achieved by having rapid unloading from the proof stress and good environmental control during the proof test.

In support of the proof-test theory, Ritter ${ }^{8}$ has shown recently for soda-lime silicate glass after proof testing that the inert strength distribution and failure time under static stress agree with that predicted from theory. Aside from this study, there has been no extensive experimental confirmation of proof-test theory. The purpose of the present study, therefore, was to conduct a detailed study of the proof-test technique and to assess the 
validity of the theory in predicting the strength after proof testing. In particular, the effectiveness of proof testing and the applicability of proof-test theory was determined by comparing the inert strength distributions of soda-lime silicate glass before and after proof testing over a range of proof-test conditions. The major proof test variables were unloading rate from the proof stress and the proof-test environment. Soda-lime-silicate glass was chosen as the model material for this study because it is readily available and because its subcritical crack behavior is well characterized.

\section{EXPERIMENTAL PROCEDURE}

All specimens used in this study were soda-lime-silicate glass, microscope stides $^{+}(7.62 \times 2.54 \times 0.10 \mathrm{~cm})$. The slides were annealed at $500^{\circ} \mathrm{C}$ for $1 \mathrm{~h}$, furnaced cooled, and then abraded in the center with a standard blast of No. 240 SiC grit. After abrasion, the samples were aged for $24 \mathrm{~h}$ in distilled water to normalize their strength and then stored in a desiccator prior to testing. Over 2000 samples were prepared in this manner and they were randomly selected for testing.

The inert strength measurements before and after proof testing were made in liquid nitrogen using four point bending. The bending apparatus had inner and outer supports of 2.54 and $5.08 \mathrm{~cm}$., respectively. A11 strength testing was done on a universal testing machine ${ }^{\dagger}$ using a constant crosshead speed of $0.2 \mathrm{~cm} / \mathrm{min}$, corresponding to a stressing rate of $5.29 \mathrm{MPa} / \mathrm{s}$. The initial inert strength distribution was determined from 79 samples while the after-proof, strength distributions were determined from about 30 samples.

\footnotetext{
${ }^{+}$Corning No. 2947

†Instron Corp., Canton, MA.
} 
The bend apparatus was also used for proof testing. The samples were loaded up to the proof stress at a stressing rate of $5.29 \mathrm{MPa} / \mathrm{s}$ and then unloaded at various rates $(132.33,5.29$, and $1.32 \mathrm{MPa} / \mathrm{s})$. The time at the proof stress varied from momentary (1ess. than $0.5 \mathrm{~s}$ ) to $60 \mathrm{~s}$. The proof test environments were liquid nitrogen, dry nitrogen gas (about $5 \%$ Relative Humidity), ambient air (55-65\% Relative Humidity) and water. The last three test environments were at room temperature, about $23^{\circ} \mathrm{C}$. Groups of 50 samples were proof tested for each proof-test condition and proof-test stresses were chosen to break approximately $40 \%$ of a set of test specimens, leaving about 30 samples for the determination of the inert strength distribution after proof testing.

\section{RESULTS AND DISCUSSION}

The strength after proof testing has been derived for 3 conditions: ${ }^{5-7}$ no flaw growth during proof testing, flaw growth up to unloading, and flaw growth during the entire proof-stress cycle. If no flaw growth occurs during the proof test, then the inert strength for a given specimen before and after proof testing are equal; however because the weak samples have been el iminated from the initial distribution, the cumulative failure probability after proof testing $\left(F_{a}\right)$ will have changed: ${ }^{5}$

$$
F_{a}=\frac{F-F_{p}}{1-F_{p}}
$$

where $F$ is the cumulative failure probability before proof testing and $F_{p}$ is the cumulative failure probability of the proof test. ${ }^{*}$

Assuming that a single power law relationship exists between subcritical crack velocity and the stress intensity factor,

${ }^{*} \mathrm{~F}$ is obtained by ordering a set of strength data. $\mathrm{F}$ is given by $r /(N+1)$ where $N$ is the total number of datum points and $r$ is the position of each point in the ordered set. $r=1$ for the lowest strength, $r=2$ for the second lowest and so forth. 


$$
V=A K_{I}^{n}
$$

where $A$ and $n$ are constants for a given material and test environment, the inert strength after proof testing $\left(S_{f}\right)$ can be derived accounting for crack growth during the proof-stress cycle. Considering crack growth up to unloading but not during unloading, the $S_{f}$ distribution is given by: 5,6

$\left(\frac{S_{f}}{S_{0}}\right)^{n-2}=\left(\ln \frac{1}{1-F_{a}}+\ln \frac{1}{1-F_{p}}\right)^{\frac{n-2}{m}}-\left(\ln \frac{1}{1-F_{p}}\right)^{\frac{n-2}{m}}+\left(\frac{\sigma_{p}}{S_{0}}\right)^{n-2}$

where $n$ is the crack propagation parameter appropriate for the proof-test environment, $\sigma_{p}$ is the proof stress, and $m$ and $S_{0}$ are the Weibull shape and scale parameters, respectively, of the initial inert strength distribution. If flaw growth occurs during the entire proof stress cycle, the $S_{f}$ distribution is now: ${ }^{6}$

$$
\left(\frac{S_{f}}{S_{0}}\right)^{n-2}=\left(\ln \frac{1}{1-F_{a}}+\ln \frac{1}{1-F_{p}}\right)^{\frac{n-2}{m}}-\left(\ln \frac{1}{1-F_{p}}\right)^{\frac{n-2}{m}}
$$

For purposes of identification in the following discussion, the various predicted $S_{f}$ distributions will be labelled:

Type I, based on Eq. (1) for no flaw growth.

Type II, based on Eq. (3) for no flaw growth on unloading.

Type III, based on Eq. (4) for flaw growth during entire proof stress cycle.

For all three types of distributions it can be shown that $S_{f}$ is greater than the initial strength at all levels of failure probability, provided $m<n-2$. For Type I and II distributions, the $S_{f}$ distribution is truncated at $\sigma_{p}$; hence, $\sigma_{p}$ represents the minimum inert strength after proof testing. When flaw growth occurs on unloading (Type III distribution), the strength distribution is not truncated and no assurances of a minimum strength can be given. 
The experimental inert strength distributions after-proof testing could be divided generally into one of four distributions depending on the proof test conditions. First, under inert proof-test conditions (liquid nitrogen) the strength distributions after proof testing agreed with that predicted from either a Type I, II, or III distribution (Fig. 1). In this case the Type II and III distributions were determined by assuming an $n=120.6$ As can be seen in Fig. $I$ there was no significant difference between the three predicted distributions within the range of the after-proof data. This observation just reflects. the fact that for an inert environment such as liquid nitrogen little or no. crack growth can occur because of the high $n$ value appropriate for this environment.

Second, with rapid unloading rates in the dry nitogen and air environments, the strength distributions after proof testing agreed with that predicted from either a. Type II or III distribution where $n=18.4^{8,9}$ (Fig. 2). Since the strength distributions after proof testing are shifted significantiy to the left of the Type I distribution, it is evident that crack growth occurs during proof testing in these "moist" environments; however, it could not be determined if the after-proof strength distributions were truncated at $\sigma_{p}$. To conclusively show truncation, much larger sample size after proof testing would have to be used (about 10000 samples).

Final1y, when good proof-test controls were not used, i.e. relatively slow unloading rates and/or moist proof-test environments, the strength distributions after proof testing either were not different significantiy from the initial distribution (Fig. 3) or were weaker than the initial distribution (Fig. 4). In these cases none of the theoretical distributions could explain the observed distributions after proof testing since the strengths were much weaker than predicted from theory. 
Table I summarizes ail the proof-test results. It is evident that for effective proof testing crack growth must be minimized through use of good proof test conditions, namely, rapid unloading rates and good environmental control. In addition, under experimental conditions where proof testing was not effective, ${ }^{+}$none of the theoretical, after-proof distributions agreed with the data. There was only one exception to these trends and that was for the proof test conducted in water at an unloading rate of $5.29 \mathrm{MPa} / \mathrm{s}$. It is not known why this one set of results did not fit into the general pattern.

To provide additional support to the general conclusions made above regarding the effectiveness of proof testing, a large group of asreceived microscope siides were proof tested in very dry nitrogen (less than $0.1 \%$ R.H.) and in moist nitrogen ( $50 \%$ R.H.) using an unloading rate of about $13.2 \mathrm{MPa} / \mathrm{s}$. Because the dry nitrogen gas was a relatively inert environment, it was used as the test environment for the strength measurements before and after proof testing. Figure 5 and 6 shows that these results are in agreement with the trends shown in Table I. When good proof-test controls are used, proof testing is effective and the strength distribution after proof testing can be characterized theoreticaliy (Fig. 5). On the other hand, when a relative slow unloading rate is used in a moist environment, proof testing is not effective in truncating the distribution and the after-proof strength distribution does not agree well with the theoretical distributions (Fig. 6).

+The reader is cautioned not to jump to the conclusion that when good proof test controls are not used, proof testing will not be beneficial. It must be remembered that our conclusion is based on a group of uniformly abraded samples that could statisticaliy be characterized by a single strength, i.e. flaw, distribution. If in a set of samples to be proof tested, some samples contain gross flaws, perhaps due to incorrect manufacturing, then proof testing even without ideal conditions, would undoubtedly eliminate these weak samples from the population, thereby, improving the reliability of the remaining samples. 
Based on the above proof test results, the question of why strengths after-proof testing under non-ideal conditions are significantly weaker than that predicted must be addressed. The use of Eq. (2) is a key assumption in deriving the strength after-proof testing. Experiments have characterized the dependence of crack velocity on stress intensity factor by three principal regions of behavior (Fig. 7). 10

Regions. I and II result from a stress corrosion reaction between the glass and water in the environment. The rate of the reaction between water and the glass controls crack motion in Region I, whereas diffusion of water to the crack tip controls crack motion in Region II, where the crack velocity is essentially constant. In Region III the stress intensity factor is close to $K_{I C}$ and crack velocity does not depend on water in the environment. Since Eq. (2) represents Region I crack growth, the equations derived for the strength after-proof testing are based on the assumption that the strength is controlled exclusively by subcritical crack growth in Region I. If the behavior shown in figure 7 is important, then Eq. (2) would overestimate crack velocity when the stress intensity factor of the crack was in the range that characterizes region II, and the theory would predict failure when in fact, the samples may just pass the proof test. The samples that just survive the proof test would then be weak, and the distribution after the proof test would not be predicted from equation 3 or 4 . Therefore, an analysis that takes into account Region II crack growth is necessary to account for the observed strength distributions after proof testing under non-ideal conditions. An analysis of this sort is presented in Part II of this paper. 


\section{ACKNOWLEDGEMENTS}

Two of the authors (JER and PBO) are grateful for the support of the National Science Foundation Grant No. DMR 77-05647 for this research; the other (E..R. Fuller, Jr. and S. M. Wiederhorn) are greatful for the support of the Department of Energy, Fossil Fuel Utilization Division. 


\section{REFERENCES}

1. S.M. Wiederhorn, A.G. Evans and D.E. Roberts, "A Fracture Mechanics Study of the Skylab Windows," pp. 829-41 in Fracture Mechanics of Ceramics, Vol. 2, Edited by R.C. Bradt, D.P.H. Hasselman and F. F. Lange, P1enum Press, New York (1974).

2. S.M. Wiederhorn, A.G. Evans, E.R. Fuller and H. Johnson, "Application of Fracture Mechanics to Space-Shuttle Windows", J. Am. Ceram. Soc., 57, $319-23$ (1974).

3. A.G. Evans, S.M. Wiederhorn, Melvin Linzer and E.R. Fuller, Jr., "Proof Testing of Procelain Insulators and Application of Acoustic Emission", Am. Ceram. Soc. Bu11., 54, 576-81 (1975).

4. J.E. Ritter, Jr. and S.A. Wulf, "An Evaluation of Proof Testing to ASsure Against Delayed Failure", to be published Am. Ceram. Soc. Bull. (1978).

5. A.G. Evans and S.M. Wiederhorn, "Proof Testing of Ceramic Materials An Analytical Basis for Failure Predictions", Int. J. Frac. Mech., 10, 379-92 (1974).

6. A.G. Evans and E.R. Fuller, "Proof Testing - The Effects of Slow Crack Growth", Mat. Sci. and Engr., 19, 69-77 (1975).

T. S.M. Wiederhorn, "Reliability, Life Prediction, and Proof Testing of Ceramics", pp 635-65 in Ceramics for High Performance Applications, Ed. by J. J. Burke, A.E. Gorum and R.N. Katz, Brook Hill Publishing Co., Chestnut Hil1, MA. (1974).

8. J.E. Ritter, Jr., "Engineering Design and Fatigue Failure of Brittle Materials", pp 667-686 in Fracture Mechanics of Ceramics, Vol. 4, Edited by R.C. Bradt, D.P.H. Hasselman, and F.F. Lange, Plenum Publishing Co., New York (1978).

9. P.B. Oates, "A Detailed Study of the Proof-Test Technique for Assuring the Mechanical Reliability of Glass", M.S. Thesis in Mechanical Engineering, University of Massachusetts (1976).

10. S.M. Wiederhorn, "Influence of Water Vapor on Crack Propagation in Soda-Lime Glass", J. Am. Cera. Soc., 50, 407-14 (1967). 
Table I. Summary of the Proof-Test Data for Soda-Lime Silica Glass.

Proof-Test Proof-Stress Hold Time at After-Proof Inert Environment Unload Rate (MPä/s) "Proof Stress (s) Strength Distribution

Liquid Nitrogen

Liquid Nitrogen

Dry Nitrogen Gas

Dry Nitrogen Gas

Dry Nitrogen Gas

Dry Nitrogen Gas

Air

Air

Air

Air

Water

Water

Water
132.22

5.29

132.33

5.29

1.32

5.29

$132.33^{\circ}$

5.29

1.32

5.29

132.33

5.29 .

5.29
$<0.5$

$<0.5$

$<0.5$

$<0.5$

$<0.5$

60

$<0.5$

$<0.5$

$<0.5$

5

$<0.5$

$<.0 .5$

5
I, II, III

I, II, III

II, III

Same as Initial

Same as Initial

Same as Initial

II, III

Weaker than Initial

Weaker than Initial

Same as Initial

Same as Initial

II, III

Same as Initial

Type theoretical distributions that agreed with after-proof data. 
FIGURES

Fig. 1. Inert strength distributions of soda-lime-silicate glass before and after proof testing compared to the theoretical, after-proof distributions. Proof testing was in liquid nitrogen at unload rate of $5.29 \mathrm{MPa} / \mathrm{s}$ and $\sigma_{p}=127.5 \mathrm{MPa}, F_{p}=0.36, n=120$, $m=8.19, S_{0}=137.4 \mathrm{MPa}$.

Fig. 2. Inert strength distributions of soda-lime-silicate glass before and after proof testing compared to the theoretical, after-proof distributions. Proof testing was in air at unload rate of 132.3 $\mathrm{MPa} / \mathrm{s}$ and $\sigma_{p}=79.3 \mathrm{MPa}, F_{p}=0.33, n=18.4, \mathrm{~m}=8.19$, $S_{0}=137.4 \mathrm{MPa}$.

Fig. 3.. Inert strength diștributions of soda-lime silicate glass before and after proof testing compared to the theoretical, after-proof distributions. Proof testing was in water at unload rate of 132.3 $\mathrm{MPa} / \mathrm{s}$ and $\sigma_{p}=68.6 \mathrm{MPa}, F_{p}=0.37, n=18.4, \mathrm{~m}=8.19, \mathrm{~S}_{0}=137.4 \mathrm{MPa}$.

Fig. 4. Inert strength distributions of soda-lime silicate glass before and after proof testing compared to the theoretical, after-proof distributions. Proof testing was in air at unload rate of $5.29 \mathrm{MPa} / \mathrm{s}$ and $\sigma_{p}=79.3 \mathrm{MPa}, F_{p}=0.47, n=18.4, m=8.19, S_{0}=137.4 \mathrm{MPa}$.

Fig. 5. Strength distributions for soda-lime-silicate glass in very dry nitrogen gas before and after proof testing compared to the theoretical, after-proof distributions. Proof testing was in very dry nitrogen gas at unload rate of $13.2 \mathrm{MPa} / \mathrm{s}$ and $\sigma_{p}=103.9 \mathrm{MPa}$, $F_{p}=0.30$, and $n=120$. 
Fig. 6. Strength distributions for soda-lime-silicate glass in very dry nitrogen gas before and after proof testing compared to the theoretical, after-proof distributions. Proof testing was in $50 \%$ R.H. nitrogen gas at unload rate of $13.2 \mathrm{MPa} / \mathrm{s}$ and $\sigma_{p}=103.9 \mathrm{MPa}$, $F_{p}=0.58$, and $n=18.4$.

Fig. 7. Crack propagation behavior of soda-lime-silicate glass in moist nitrogen gas environments. Percent relative humidity is given on the right hand side of diagram (after Wiederhorn, reference 10). 


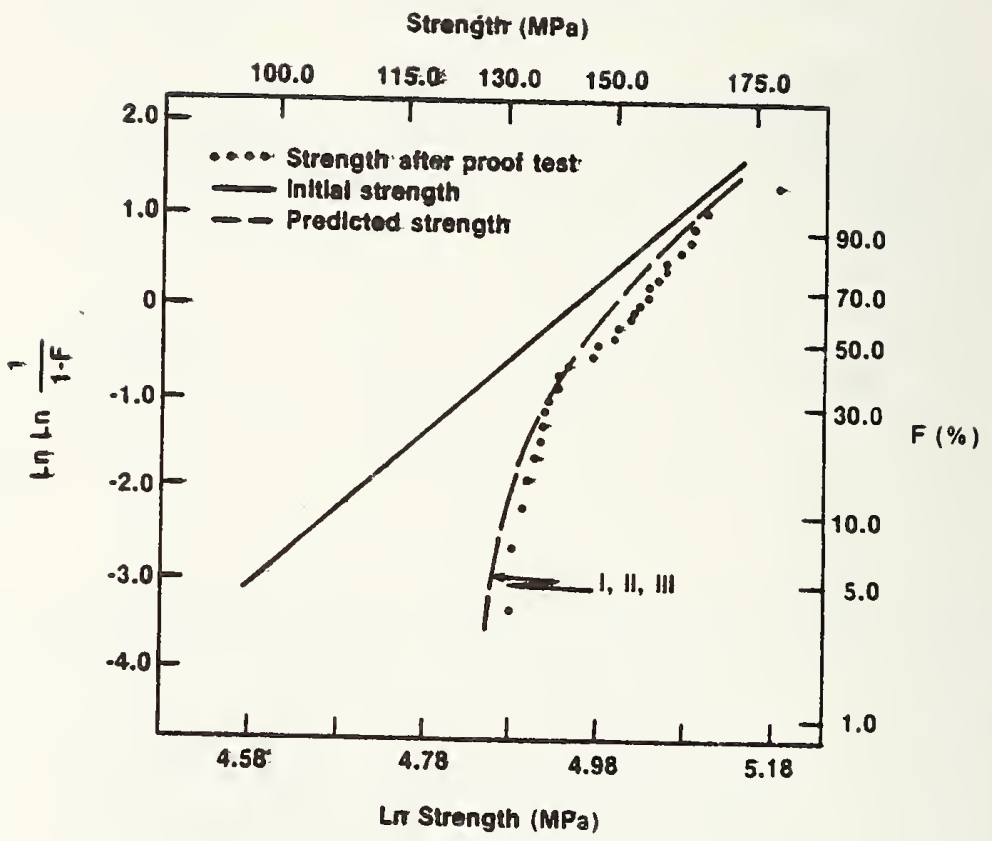

Fig. 1. Inert strength distributions of soda-lime-silicate glass before and after proof testing compared to the theoretical, after-proof distributions. Proof testing was in liquid nitrogen at unload rate of $5.29 \mathrm{MPa} / \mathrm{s}$ and $\sigma_{p}=127.5 \mathrm{MPa}, F_{p}=0.36, n=120$, $m=8.19, \mathrm{~S}_{0}=137.4 \mathrm{MPa}$. 


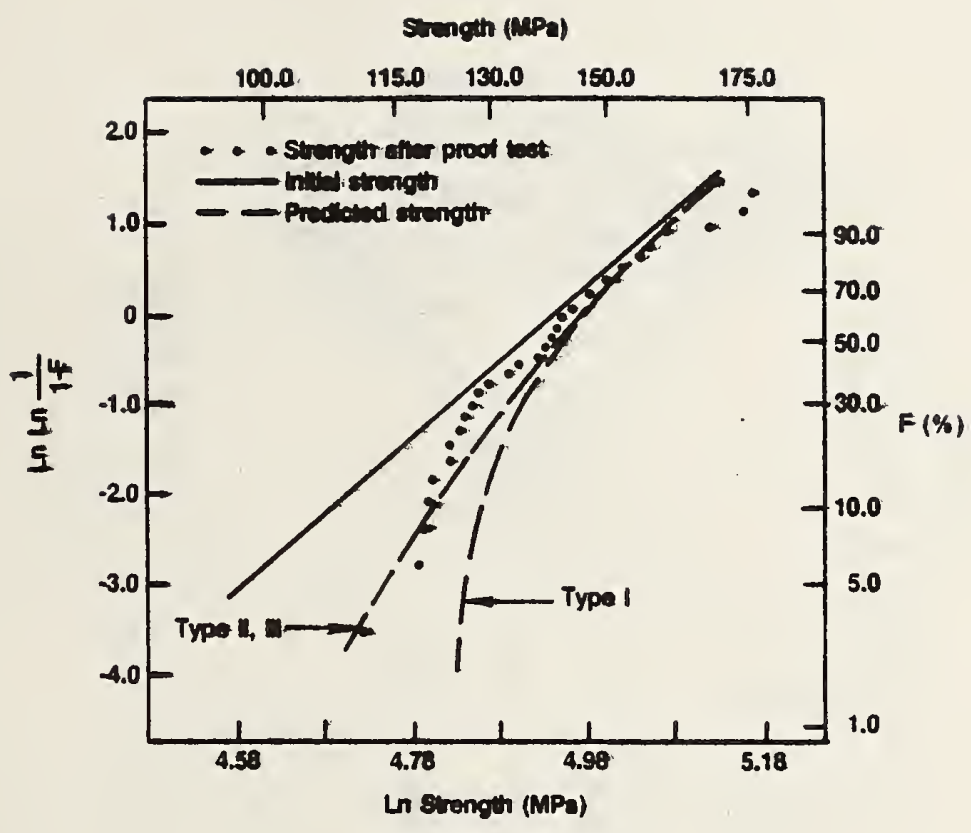

Fig. 2. Inert strength distributions of soda-lime-silicate glass before and after proof testing compared to the theoretical, after-proof distributions. Proof testing was in air at unload rate of 132.3 $\mathrm{MPa} / \mathrm{s}$ and $\sigma_{\mathrm{p}}=79.3 \mathrm{MPa}, \mathrm{F}_{\mathrm{p}}=0.33, n=18.4, \mathrm{~m}=8.19$, $S_{0}=137.4 \mathrm{MPa}$. 


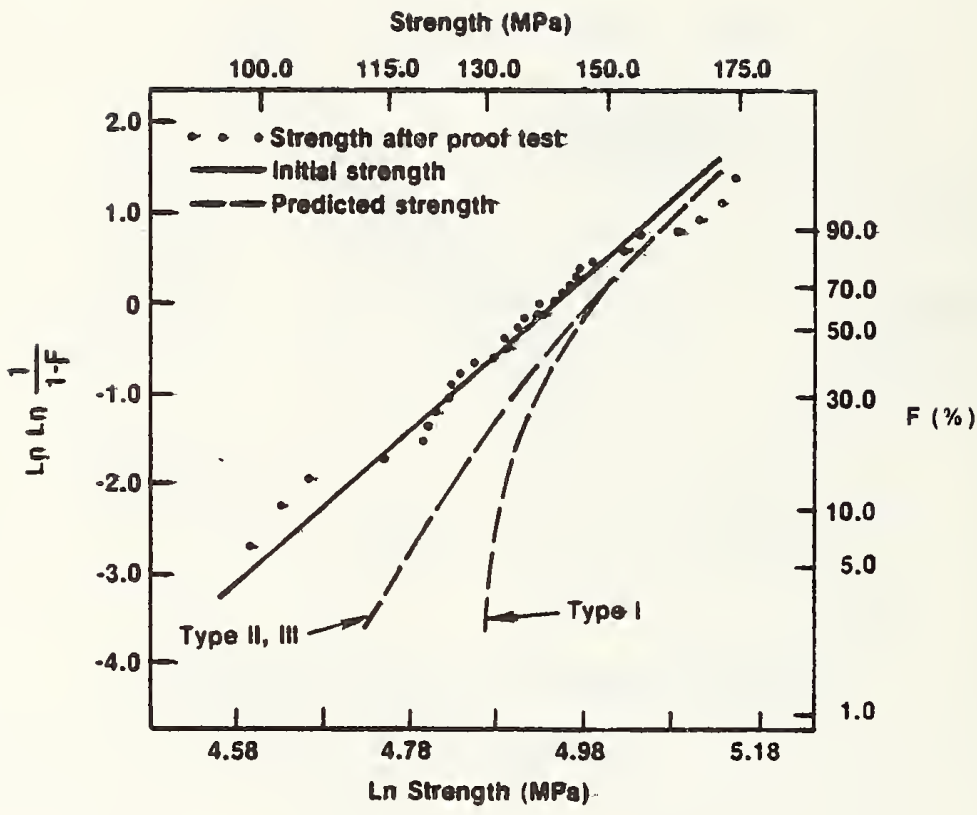

Fig. 3. Inert strength distributions of soda-lime silicate glass before and after proof testing compared to the theoretical, after-proof distributions. Proof testing was in water at unload rate of 132.3 $\mathrm{MPa} / \mathrm{s}$ and $\sigma_{p}=68.6 \mathrm{MPa}, F_{p}=0.37, n=18.4, m=8.19, \mathrm{~S}_{0}=137.4 \mathrm{MPa}$. 


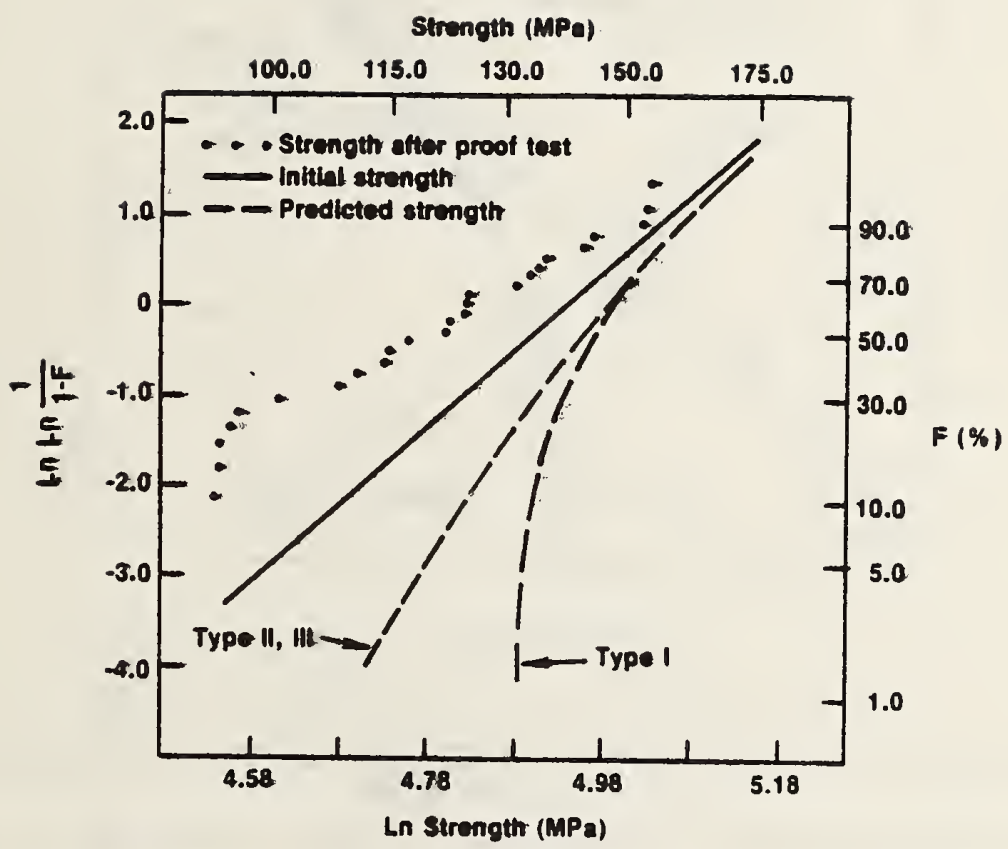

Fig. 4. Inert strength distributions of soda-lime silicate glass before and after proof testing compared to the theoretical, after-proof distributions. Proof testing was in air at unload rate of $5.29 \mathrm{MPa} / \mathrm{s}$ and $\sigma_{p}=79.3 \mathrm{MPa}, F_{p}=0.47, n=18.4, m=8.19, S_{0}=137.4 \mathrm{MPa}$. 


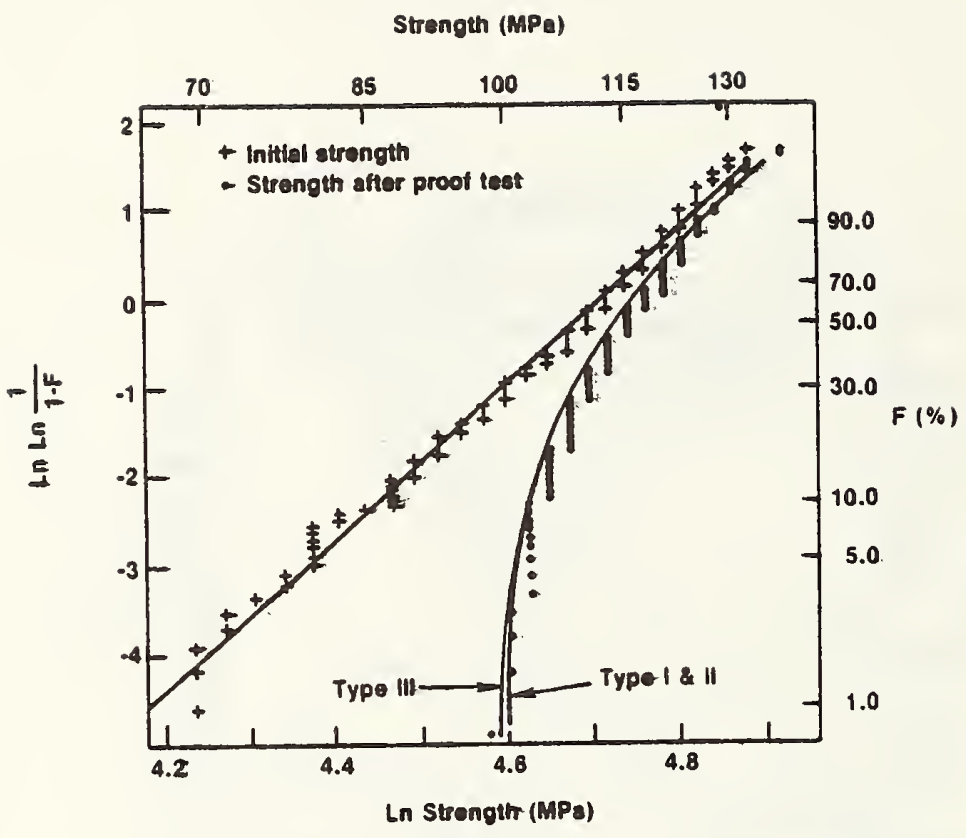

Fig. 5. Strength distributions for soda-lime-siticate glass in very dry nitrogen gas before and after proof testing compared to the theoretical, after-proof distributions. Proof testing was in very dry nitrogen gas at unload rate of $13.2 \mathrm{MPa} / \mathrm{s}$ and $\sigma_{p}=103.9 \mathrm{MPa}$, $F_{p}=0.30$, and $n=120$. 


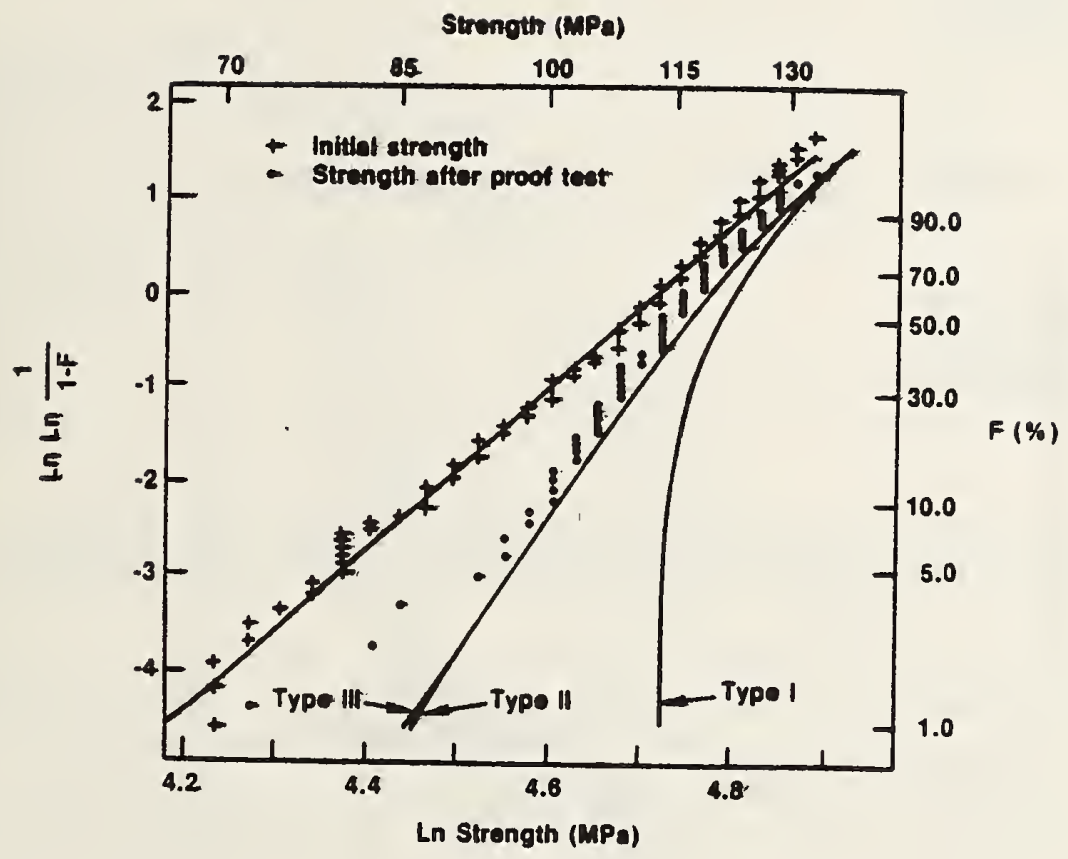

Fig. 6. Strength distributions for soda-lime-silicate glass in very dry nitrogen gas before and after proof testing compared to the theoretical, after-proof distributions. Proof testing was in $50 \%$ R.H. nitrogen gas at unload rate of $13.2 \mathrm{MPa} / \mathrm{s}$ and $\sigma_{p}=103.9 \mathrm{MPa}$, $F_{p}=0.58$, and $n=18.4$. 


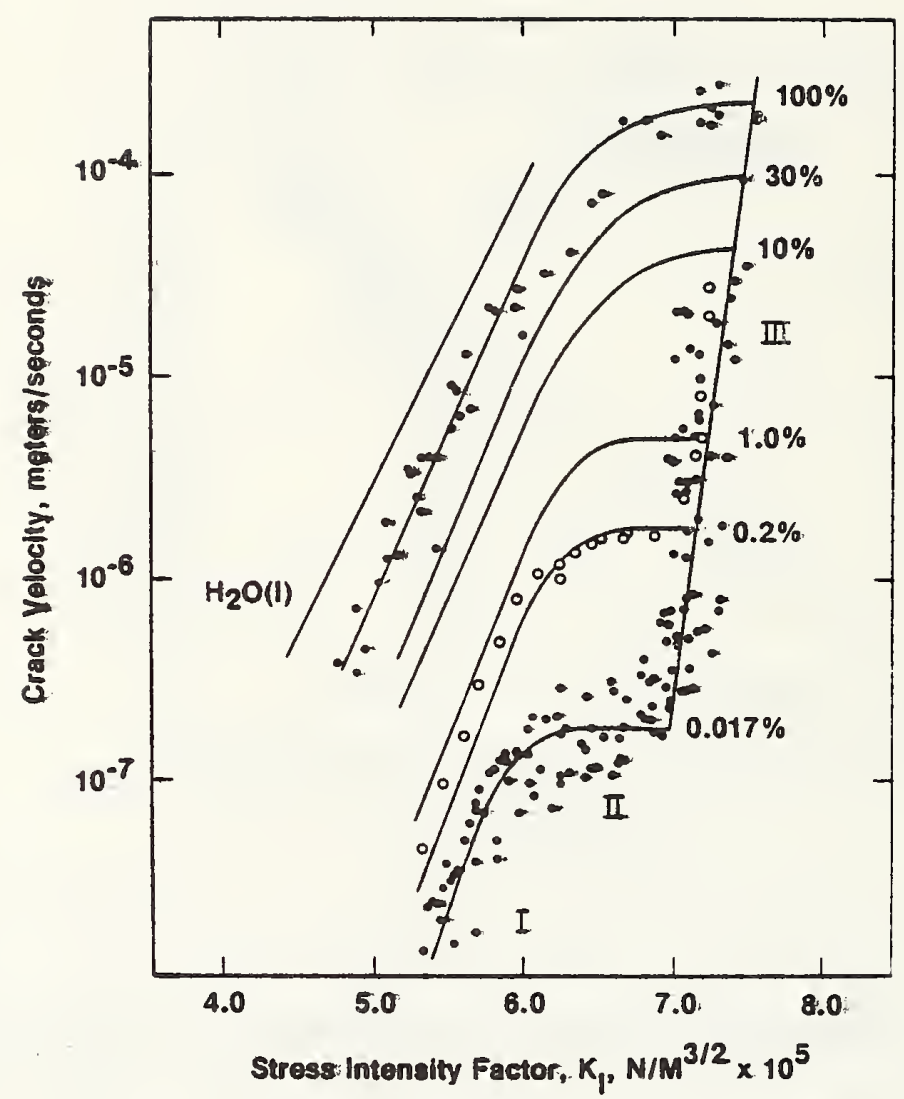

Fig. 7. Crack propagation behavior of soda-lime-silicate glass in moist nitrogen gas environments. Percent relative humidity is given on the right hand side of diagram (after Wiederhorn, reference 10). 
U.S. DEPT. OF COMM.

BIBLIOGRAPHIC DATA SHEET

4. TITLE AND SUBTITLE

Proof Testing of Ceramics: I. Experiment
1. PUBLICATION OR REPORT NO.
$79-1934$

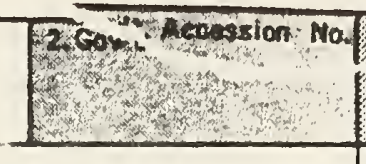

5. Publication Date

\section{wו}

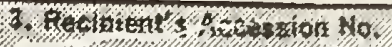

G. Ferforming Organization Code

8. Performing Organ. Report No.

7. AUTHOR(S) J. E. Ritter, Jr., P. B. Oates, E. R. Fuller, Jr. nd S. M. Wiederhorn

9. PERFORMING ORGANIZATION NAME AND AODRESS

10. Projectrask/Nork Únit No.

NATIONAL BUREAU OF STANDARDS

DEPARTMENT OF COMMERCE

WASHINGTON, DC 20234

12. SPONSORING ORGANIZATION NAME AND COMPLETE ADDRESS (Stroot, Clty, State, ZIP)

Department of Energy

Fossil Fuel Utilization Division

Washington, D. C.

11. Contract/Grant No.

13. Type of Report \& Period Covered

14. Sponsoring Agancy Code

15. SUPPLEMENTARY NOTES

Document describes a computer program; SF-185, FIPS Software Summary, is attached.

16. ABSTRACT (A 200-word or less factual summary of most significant information. If document includes a signlficant bibliography or literature survey, mention it here.)

The effectiveness of proof testing as a method of improving component reliability was studied by comparing the inert strength distributions of soda-lime-silicate glass before and after proof testing. The effects of unloading rate from the proof stress, hold time at the proof stress, and proof-test environment were examined. The results indicate that the proof test must be conducted with rapid unloading rates and good environmental control to be effective. The theoretical implications of these results are discussed.

17. KEY WOROS (six to twolve ontries; alphabetical order; capitalize only the first letter of the first key word unless a proper name; soparated by amicolons)

Ceramics; crack growth; fracture; glass; proof testing; strength

\begin{tabular}{|l|c|}
\hline $\begin{array}{l}\text { 19. SECURITY CLASS } \\
\text { (THIS REPORT) }\end{array}$ & $\begin{array}{c}\text { 21. NO. OF } \\
\text { PRINTED PAGES } \\
\text { UNCLASSIFIED }\end{array}$ \\
\hline $\begin{array}{l}\text { 20. SECURITY CLASS } \\
\text { (THIS PAGE) }\end{array}$ \\
$\begin{array}{l}\text { UNCLASSIFIED } \\
\text { UNICE }\end{array}$ \\
\hline
\end{tabular}



NBSIR $79-1944$

PROOF TESTING OF CERAMICS:

II. THEORY

E.R. Fuller, Jr. and S.M. Wiederhorn

Fracture and Deformation Division

National Measurement Laboratory

Center for Materials Science

National Bureau of Standards

J.E. Ritter, Jr. and P.B. Oates

Mechanical Engineering Department

University of Massachusetts

Amherst, MA 01003

Published in:

Journal of Materials Science

$15,2282-2295(1980$ 

Proof Testing of Ceramics: II. Theory

E. R. Fuller, Jr. and S. M. Wiederhorn National Bureau of Standards Washington, D. C. 20234

and

J. E. Ritter, Jr. and P. B. Oates Mechanical Engineering Department University of Massachusetts

Amherst, Mass. 01003 


\section{ABSTRACT}

Theoretical estimates are made of strength distributions after proof testing. Assuming that the crack velocity can be expressed as a power function of the stress intensity factor, $V=A K_{I}{ }^{n}$, an analysis of the amount of strength loss during a load cycle is presented for singleregion crack propagation. For multi-region crack propagation, a numerical analysis is used to describe strength loss. In both analyses, the effects of environment and loading rate are studied. For single region crack propagation, the strength after proof testing can be represented by two Weibull curves: one with a slope of $m$ at high cumulative failure probability levels; the other with a slope of $n-2$ at low failure probability levels. Truncation of the strength distribution always occurs as the result of proof testing; the truncation strength depends on the rate of unloading. Multi-region crack propagation results in a more complicated strength distribution after proof testing. Bimodal strength distributions occur as a consequence of region II type crack growth (i.e. $n=0$ ). Theoretical results confirm experimental findings that proof tests must be conducted at rapid unloading rates and with good environmental control to be effective. 
Proof Testing of Ceramics: II. Theory

1. Introduction

The first part of this two part study presented the results of an experimental investigation of the effect of proof testing on the strength of a set of soda-lime silicate glass microscopic slides. Effects of stress cycle and test environment were investigated. Agreement between experimental results and theoretical predictions of strength distributions after proof testing were obtained when proof tests were conducted in inert environments, or when rapid rates of loading and short hold times were used in the proof tests. By contrast, when water was present in the environment and when slow rates of loading were used, strength distributions were obtained after proof testing that were not consistent with simple theoretical predictions. At the conclusion of Part I of this study, we noted that the lack of agreement between theory and experiment may be a consequence of the complex crack growth behavior associated with crack motion in moist gaseous environments. We also suggested that additional theoretical work be conducted to explore the possibility of complex crack growth effects on strength distributions. The second part of this study explores this possibility.

In part II of this paper the effect of complex crack growth behavior on the strength distribution after proof testing is explored by the use of a modified fracture mechanics approach. Although fracture mechanics is used as an basis for understanding proof testing, strength degradation is discussed in terms of component strength and applied stress, a modification which permits the process of strength degradation to be illustrated graphically in a relatively simple manner. Because this approach is new, a review of the earlier literature is presented to achieve a uniform and comprehensive picture of the subject. Strength degradation resulting from simple crack growth behavior (i.e., one region 
of crack growth) is treated analytically, while complex crack growth behavior is treated numerically. This study illustrates the types of strength distribution curves to be expected from a population of test specimens after they have been proof tested. The complex stress distributions reported in Part I of this paper for soda lime silicate glass are supported by the results obtained in this part of the paper. The importance of environmental control and rapid unloading during a proof test is also confirmed.

2. Strength and Crack Growth Behavior

The strength of ceramics is determined by the presence of small, so-called Griffith cracks in the surface. When stresses reach a critical value, crack propagation occurs and ceramics fail by brittle fracture. The level of stress required for crack propagation depends on the test environment, crack growth usually occurring more easily in the presence of water. The effect of water on crack growth has been used to explain the well-known phenomenon of static fatigue, or delayed failure, which is a stress enhanced reaction in which water in the environment behaves as the stress corrosion agent. '

The advent of fracture mechanirs provided a method of developing deeper insight into crack growth processes in ceramic materials. ${ }^{2}$ Fracture mechanics also offers the possibility of relating fundamental crack-growth data to strength data, so that techniques of assuring the reliability of structural materials can be developed. ${ }^{3}$ Data obtained on ceramic materials by fracture mechanics techniques provide a relation between the crack growth velocity, $v$, and the driving force for fracture, the stress intensity factor, $K_{I}$. In soda lime silicate glass, the crack velocity is dependent on both the applied stress intensity factor, $K_{I}$, and on the amount of water in the environment. The three regions of crack growth (shown schematically in figure 1) depend on the amount of water in the environment and the, stress intensity level at the crack 
tip. Regions I and II result from a stress corrosion reaction between glass and water: Region I represents reaction rate limited stresscorrosion cracking; Region II represents transport rate limited stresscorrosion cracking. Region III represents environment independent fracture that depends only on the structure of the glass, and is not observed for all glass compositions. The scientific significance of this type of data has been discussed at length elsewhere, and will not be repeated here. ${ }^{4}$ For purposes of the present paper, this type of data can be used to calculate the fracture strength of glass or other ceramic materials after they have been subjected to a proof test.

Crack propagation data can be used to estimate the amount of crack growth occurring in a component that is subjected to an applied stress. Given an initial measure of the crack length, the change in crack length can be estimated from the applied load, and a functional relation between the crack velocity, $v$, and the stress intensity factor, $K_{I}$, (i.e. $v=v\left(K_{I}\right)$ ). For a uniform applied stress, $\sigma$, and a crack length $\underline{a}, K_{I}$ is given by

$$
K_{I}=\sigma Y \sqrt{\underline{a}}
$$

where $Y$ is a geometric constant. If the relation between $v$ and $K_{I}$ has the form $v=A K_{I}{ }^{n}$, then crack growth during a stress cycle can be determined analytically and the strength of a component after a random stress cycle can be obtained. If the relation between $v$ and $K_{I}$ does not have a simple form (eq. fig. 1) then the strength of a component after a random stress cycle can be obtained numerically. In either case, failure occurs during the stress cycle when the stress intensity factor reaches a critical value, $K_{I C}$, for rapid fracture.

Quantitative estimates of the amount of crack growth during a stress cycle can be used to evaluate the strength of a component at any point in the cycle. The fracture. strength, $S$, at any time during the cycle 
can be defined in terms of the crack length, $\underline{a}$, and the critical stress intensity factor $K_{I C}$, from $E q .(1): *$

$$
S=K_{I C} / Y \sqrt{\underline{a}}
$$

If the stress, $\sigma$, equals the strength, $S$, at any point in the cycle, then $K_{I}=K_{I C}$, and failure occurs. By evaluating the effect of a stress cycle on strength, it is possible to calculate theoretical Weibull probability curves, which can then be compared with experimental ones obtained from proof-test studies. Furthermore, by using a numerical procedure to evaluate the strength after a load cycle, the effect of multi-region crack propagation can be taken into account.

The strength degradation that occurs during a stress cycle can be represented by a relatively simple diagram on which are plotted simultaneously the strength of a component and the applied stress at any time during a stress cycle. Figure $2 a$ gives a schematic representation of a strength degradation diagram which is based on the assumption that onty one region of crack growth contributes to reduction of component strength. The diagram represents a typical proof test cycle. The applied stress on the diagram is represented by the curve labelled $\sigma$ which consists of three straight lines: one line representing a constant rate of stress increase during the stress cycle; the second, horizontal line representing a hold time during the proof test; the third line representing the stress reduction as the proof test cycle is completed. Although the diagram shown in figure $2 \mathrm{a}$ is for a simple proof test cycle, any stress cycle can be represented in a similar way.

*As defined in equation 2, the strength is simply related to the length of the critical flaw that causes failure. In operational terms, $S$ is the inert strength at any point of the stress cycle. It is the breaking stress that would be measured if the component could be loaded to failure in such a way that subcritical crack growth did not occur at all during the strength test. 
The strength of components during a stress cycle is illustrated in figure $2 a$ by curves labelled, $S_{1}, S_{2}$ and $S_{3}$. Each of these curves represents components having different initial strengths (i.e. strengths before the start of the proof test). As the stress level in figure $2 a$ is increased (curve $\sigma$ ), cracks present in specimens increase in size, resulting in a gradual decrease in strength. Strength degradations occurs most rapidly as the stress, $\sigma$, approaches the strength of the specimen. For specimens with initial strengths, $S_{j}$, much greater than the maximum applied stress, little strength degradation occurs during the load cycle. However, when the initial strength, $\mathrm{S}_{2}$, is less than or approximately equal to the maximum applied stress, the specimen breaks during the test, and the breaking stress is less than that which would have been measured in the absence of crack growth. Breakage during the proof test can also occur when the initial strength, $S_{3}$, is greater than the maximum applied stress provided sufficient crack growth occurs during the stress cycle.

The effect of multi-region crack propagation can also be represented on this type of diagram. The lines, labelled $\Sigma_{0}, \Sigma_{1}$ and $\Sigma_{2}$ in figure $2 b$, represent the strength of components at the boundaries that separate the different regions of crack propagation (fig. 1). For a given applied stress, these boundaries define the range of strengths that lie within each region of crack growth. The position of the boundary lines in figure $2 \mathrm{~b}$ can be evaluated from the values of $K_{I}$ in figure 1 that define the limits of each region of crack growth (i.e. $k_{0}, k_{1}, k_{2}$ ). For example, the curve $\Sigma_{\eta}$, that corresponds to the boundary between regions I and II in Fig. $1, K_{I}=K_{1}$, is given in fig. $2 b$ by $\Sigma_{1}=\sigma\left(K_{I C} / K_{1}\right)$, which is obtained from equations 1 and 2 by setting $K_{I}=K_{1}$ and $S=\Sigma_{\eta}$. Thus, the boundary 1 ines in figure $2 b$ are proportional to $\sigma$, and since the proportionality constant, 
$\mathrm{K}_{\mathrm{IC}} / \mathrm{K}_{1}$, is greater than $1, \Sigma_{1}$ is greater than the applied stress, $\sigma$. In a similar way, the boundary lines for $K_{0}$ is given by $\Sigma_{0}=\sigma\left(K_{I C} / K_{0}\right)$ and that for $K_{2}$ is given by $\Sigma_{2}=\sigma\left(K_{I C} / K_{2}\right)$.

During a proof test cycle, the value of the stress intensity factor at the most severe flaw crosses from one region of crack propagation to the next in figure 1 as the crack gets longer. At the same time the strength goes from one region of crack growth to the next each time the curve in figure $2 \mathrm{~b}$ marked $\mathrm{S}$ crosses the boundary lines. At each boundary, both the slope and value of the strength curve are continuous.* Again, fracture occurs spontaneously when the strength curve touches the stress cycle boundary (i.e. when $\sigma=S$ ). In later sections of the paper, specific examples of these diagrams will be given.

3. Single Region Crack Propagation

To understand the types of curves obtained on strength degradation maps, it is worth exploring single-region srack propagation. An exploration of this simple case is also useful for quantifying the basic types of curves that are to be expected in failure distributions and strength histograms. Some of the subject matter presented here has been discussed earlier, ${ }^{5-11}$ but the treatment presented here is somewhat simplified and the results are more complete. As will be shown, this simplification is the result of considering subcritical crack growth from the point of view of strength degradation rather than crack length. New insight into the strength degradation process is attained by this approach.

\footnotetext{
As is shown in equation 3 , the slope of the strength curve depends on both the crack length and the crack velocity. Since both of these are continuous throughout the test region, the slope must be continuous.
} 
For single-region crack propagation, an analytical solution can be obtained and used to plot strength degradat, on diagrams, Weibull diagrams and strength histograms. In later sections of the paper, examples of such diagrams will be presented for a variety of crack propagation environments. These diagrams will be used both as a means of evaluating the effect of stressing rate and stress cycle on strength and as a basis for comparison with more complex multi-region crack propagation behavior.

The rate of strength degradation can be obtained by differentiating equation 2 with respect to time,

$$
d S / d t=-\left(K_{I C} / 2 Y\right) \underline{a}^{-3 / 2}(\underline{d a} / d t)=-\left(Y^{2} / 2 K_{I C}{ }^{2}\right) S^{3} v(K)
$$

Thus, the rate of strength degradation depends only on the strength, the crack velocity and the materials parameter $K_{I C}$. Expressing the crack velocity as a simple power function of the stress intensity factor

$$
V=A K_{I}{ }^{n}=A K_{I C}{ }^{n}(\sigma / S)^{n}
$$

the rate of strength decrease becomes:

$$
d S / d t=-\left(A Y^{2} K_{I C}{ }^{n-2} / 2\right)(\sigma / S)^{n} S^{3}
$$

This equation gives the slope of the strength degradation curve at any point on the strength degradation diagram (figure 2). Provided appropriate values of $A$ and $n$ are used, equation 5 is applicable to each region of behavior in multi-region crack growth exposure. As will be shown below this finding has important implications in determining the minimum strength of a set of components that have been proof-tested. For a given value of $\sigma / S$, the rate of strength degradation, $-d S / d t$, increases as $n$ increases. Note that when $n=0$ (region 2 crack growth) $d S / d t$ decreases in absolute magnitude as the strength decreases, equaling zero as $\mathrm{S}$ approaches zero. Consequently, dS/dt exhibits positive curvature when $n=0$. For region I $(n \geq 15)$ or for region III $(n \geq 100)$ crack growth, however, dS/dt exhibits strong negative curvature. 
For any load cycle, equation (5) can be integrated analytically to provide a relation between the initial strength, $S_{i}$ (i.e. before proof testing), and the strength, $S$ at any time, $t$, during the proof test cycle.

$$
s^{n-2}-s_{i}^{n-2}=-(1 / B) \int_{0}^{t} \sigma(t)^{n} d t
$$

where $(I / B)=(n-2) A Y^{2} K_{I C}{ }^{n-2} / 2$. The amount of strength degradation during a stress cycle depends only on the integral given on the right hand side of the equation, so that the strength degradation can be determined for any stress cycle provided the applied stress, $\sigma$, is known as a function of time. 6

For a typical proof test, a component is loaded at a constant loading rate, $\sigma_{j}$, held at the proof load, $\sigma_{p}$, for a time $t_{p}$, and then unloaded at a constant rate, $\dot{\sigma}_{u}$. The times for loading, $t_{1}$, and unloading, $t_{u}$, the specimens are given by: $t_{1}=\sigma_{p} / \dot{\sigma}_{1} ; t_{u}=\sigma_{p} / \dot{\sigma}_{u}$. Integrating equation (6) for a typical load cycle then gives the following equation for the final strength, $S_{f}:^{\top}$

$$
S_{f}^{n-2}=S_{i}^{n-2}-(1 / B)\left[\sigma_{p}{ }^{n} t_{p}+\sigma_{p}^{n+1}\left(1 / \dot{\sigma}_{1}+1 / \dot{\sigma}_{u}\right) /(n+1)\right]
$$

for any component that does not break during the proof test.

The development of adequate proof testing procedures for ceramic materials requires the strength distribution after proof testing to be well characterized, especially in the low strength regime. This characterization is especialty necessary when fracture and/or crack propagation occurs during the unloading cycle of the proof test. To characterize fully the strength distribution after proof testing it is necessary not only to know $S_{f}(e q .7)$, but also to know the breaking stress of those specimens that fail during the proof test. This step is needed for the determination of the minimum survival strength after the proof test. 
The breaking stress, $\sigma_{*}$, of those that fail during the unloading portion of the proof test can be obtained from equation 6 by setting $S=\sigma_{*}$. The upper limit of integration of equation 6 is then equal to $t=\sigma_{p} / \dot{\sigma}_{1}+t_{p}+\left(\sigma_{p}-\sigma_{*}\right) / \dot{\sigma}_{u}$, which is the total time to failure during the proof test. The equation so obtained is given by

$$
\begin{aligned}
\sigma_{*}{ }^{n-2}-(1 / B) \sigma_{*}{ }^{n+1} /(n+1) \dot{\sigma}_{u} & = \\
& s_{i}{ }^{n-2}-(1 / B)\left[\sigma_{p}{ }^{n} t_{p}+\sigma_{p}{ }^{n+1}\left(1 / \dot{\sigma}_{1}+1 / \dot{\sigma}_{u}\right) /(n+1)\right]
\end{aligned}
$$

We now have two equations, 7 and 8 , that describe specimen behavior during a proof test. Equation 7 gives the strength, $S_{f}$, of components that pass the proof test cycle, whereas equation 8 gives the breaking stress, $\sigma_{*}$, of components that do not pass the proof test cycle. Both equations are expressed in terms of the load cycle parameters $\left(\sigma_{p}, \dot{\sigma}_{j}, \dot{\sigma}_{u}, t_{p}\right)$, the crack propagation parameters ( $B$ and $n$ ) and the initial component strength, Si, before the start of the proof test cycle. If the initial strength, $\mathrm{Si}$, is relatively high, the component will pass the proof test; whereas if the initial strength is low, the component will break during the proof test cycle (figure 3a). There is a critical initial strength, $\mathrm{Si}^{*}$, that will separate components that break, $\mathrm{Si}<\mathrm{Si}^{*}$, from those that survive, Si>Si* , the proof test cycle. The component that has an initial strength that is infinitesimally greater than $S i^{*}$ will have a final strength, $S_{\text {fmin }}$, that forms a lower bound for the strengths of components that pass the proof test (figure 3a). $S_{\text {fmin }}$ is important because it represents the lowest possible strength of components that have been subjected to a proof test cycle. $S_{\text {fmin }}$ is in effect the truncation strength for the strength distribution after the completion of the proof test. By similar reasoning, the component that has an initial strength that is infinitesimally less than $5 i^{*}$ will break at a stress, $\sigma_{*_{\min }}$, that forms a lower bound to the breaking stresses of components that fait during the unloading cycle (figure $3 a$ ). 
A relationship between the minimum strength, $S_{\text {fmin }}$, after the proof test cycle, and the minimum breaking stress, $\sigma_{\text {mmin }_{n}}$, can be obtained by setting $\mathrm{Si}=\mathrm{Si}{ }^{*}$ in equations 7 and 8 and equating the left hand sides of these equations:

$$
s_{\text {fmin }}^{n-2}=\sigma_{x_{\min }}^{n-2}\left[1-(1 / B(n+1))\left(\sigma_{x_{\min }}^{3} / \dot{\sigma}_{u}\right)\right]
$$

Equation 9 can be simplified by expressing $\sigma_{\pi_{m}}$ in in terms of the unloading rate. During unloading, the strength degradation curve that characterizes $S_{\text {fmin }}$ will approach within an infinitesimal distance of the stress curve, but will fail to touch it. At the point of closest approach of the two curves, the slope, dS/dt, of the strength curve will be equal to the slope, $-\dot{\sigma}_{u}$, of the stress curve. By letting $d S / d t=-\dot{\sigma}_{u}$ and $\sigma=S=\sigma_{x_{m} \text { in }}$ in equation 5 , the following equation is obtained:

$$
\sigma_{\star_{\min }}=\left[B(n-2) \dot{\sigma}_{u}\right]^{1 / 3}
$$

By substituting this relation for $\dot{\sigma}_{u}$ in equation (9) a simple equation is obtained for the minimum strength after proof-testing:

$$
S_{\text {fmin }}=\sigma_{\min }[3 /(n+1)]^{1 /(n-2)}
$$

One concludes from this equation that the strength, $S_{f m i n}$, of a component that just survives the proof test is aiways less than the breaking stress, $\sigma_{* m i n}$, of a one that just breaks during the proof test. Because $n$ for most ceramic materials is large, $>10, \mathrm{~S}_{\text {fmin }} / \sigma_{\text {min }}$ is normally greater than 0.85 .

Equation 10 can be written in an alternative form that is useful when relating the truncation strength, $S_{f m i n}$, to parameters that describe crack growth. By expressing $B$ in terms of the crack growth parameters $A$ and $n$, and by defining a limit crack velocity (fig $I b$ ), $V_{I C}=A K_{I C}{ }^{n}$, the following alternative representation of equation 10 is obtained:

$$
\sigma_{* \min }=\left[\left(2 \dot{\sigma}_{U} K_{I C}{ }^{2}\right) /\left(V_{I C} Y^{2}\right)\right]^{1 / 3}
$$

From equations 11 and 12 we note that the truncation strength, $S_{\text {fmin }}$, depends only on the unloading rate, $\dot{\sigma}_{u}$, the critical stress intensity 
factor, and the 1 imit crack velocity, $V_{I C}$, which is determined by the crack propagation parameters, $A$ and $n$. Th refore, the truncation strength does not depend on the proof-test level, the time at load, or the loading rate. If $\dot{\sigma}_{u}>0$, equations 11 and 12 imply that proof testing always truncates the strength distribution. The higher the unloading rate, $\dot{\sigma}_{u}$, the greater is the strength level, $\mathrm{S}_{\text {fmin }}$, at which strength truncation occurs. Fracture during the unloading part of the cycle can be avoided provided the unloading rate is sufficiently great that $\sigma_{x_{\min }}$ calculated from equations 10 or 12 is greater than the proof test load, $\sigma_{p}$. This condition for truncation was noted earlier by Evans and Fuller ${ }^{7}$ from other considerations. However even if $\sigma_{*_{\min }} \geq \sigma_{m}$, strength degradation will still occur during unloading so that $S_{\text {fmin }}$ will be lass than $\sigma_{p}$ (eq. 11). Finally, since the only crack growth parameters that influence $\sigma_{*_{m}}$ are those that occur when $V=V_{I C}$, equation 12 should also apply to multi-region crack growth, for which the intersection of the region III curve with $K_{\text {IC }}$ (fig. Ib) normally determines $V_{I C}$.

4. Single Region Crack Propagation: Statistical Parameters

Since proof testing modifies the initial strength distribution, a discussion of the shape of the distribution curve that results from proof testing is important. The treatment of strength degradation given above provides all of the necessary information to determine the effect of a stress cycle on the strength distribution. The change in strength during the proof test can be determined from equation 7 , while the change in probability can be determined from simple probability theory. Therefore, if the initial strength, Si, is known as a function of the initial cumulative failure probability, Fi, the strength after proof testing, $S_{f}$, can be evaluated in terms of the cumulative failure probability, $F_{f}$, of the components that pass the proof test by the use of simple transformations of both strength (equation 7) and failure probability. This approach to estimating the effect of proof testing on the strength 
distribution is illustrated below for a two-parameter Weibull distribution.

Although the approach is not limited to Weibull statistics, this form of extreme-val statistics is easy to use and provides a relatively accurate description of the strength distribution for brittle materials. Two-parameter

Weibull statistics can be easily incorporated into the present treatment of proof-testing, so that strength distributions after proof-testing can be expressed in terms of statistical parameters. $3,7,10,11$

Weibull statistics relate the cumulative fallure probability, $F$, to the strength, $S$, by the following standard equation ${ }^{*}:{ }^{12}$

$$
\ln \left(\ln (T-F)^{-1}\right)=\min \left(S / S_{0}\right)
$$

where $m$ and $S_{0}$ are parameters that are determined from experimental data by a least squares fit or by other methods of estimation. ${ }^{13}$. For simplicity in succeeding calculations let $\ln (1-F)^{-1} \equiv Q$. Note that for small values of the failure probability $Q=F(F<0.07)$. If $Q_{j}$ is determined by the initial strength distribution before proof testing, then equation (13) can be simply expressed as:

$$
Q_{i}=\left(S_{i} / S_{0}\right)^{m}
$$

From probability theory the initial failure probability (as characterized by $Q_{j}$ ) can be related to the failure probability after proof testing (as characterized by $Q_{f}$ ) and the failure probability of the component that just fails during the proof test (characterized by $Q_{p}$ ).

$$
Q_{i}=Q_{f}+Q_{p}
$$

* $F$ is obtained by ordering a set of strength data. $F$ is given by $r /(N+7)$ where $\mathbb{N}$ is the total number of datum points and $r$ is the position of each point in the ordered set. $r=1$ for the lowest strength value, $r=2$ for the second lowest and so forth.

t. Equation 15 follows from the probability relation $F_{f}=\left(F_{f}-F_{p}\right) /\left(1-F_{p}\right)$ where $F_{f}$ is the failure probability after proof-testing, $F_{j}$ is the initial failure probability evaluated from eqn. 13 and $F_{p}$ is the proof test failure probability. ${ }^{10}$ 
By substituting equation (14) and (15) into equation (7), the strength $S_{f}$, after a proof test can be expressed in terms of the cumulative failure probability (represented by $Q_{f}$ ):

$\left(S_{f} / S_{0}\right)^{n-2}=\left(Q_{f}+Q_{p}\right)^{\frac{n-2}{m}}-(1 / B) S_{0}{ }^{-(n-2)}\left[\sigma_{p}{ }^{n_{t}}{ }_{p}+\sigma_{p}{ }^{n+1}\left(1 / \dot{\sigma}_{1}+1 / \dot{\sigma}_{u}\right) /(n+1)\right]$

Equation 16 can be simplified considerably by noting that for the specimen that just survives the proof test cycle $S_{f} \rightarrow S_{\text {fmin }}$ and $Q_{f} \rightarrow 0$. Substituting for $S_{f}$ and $Q_{f}$ in equation 16, the following expression is obtained for the last term on the right of equation 16:

$(1 / B) S o^{-(n-2)}\left[\sigma_{p} n_{t}+\sigma_{p}^{n+1}\left(1 / \dot{\sigma}_{1}+1 / \dot{\sigma}_{u}\right) /(n+1)\right]$

$$
=Q_{p} \frac{n-2}{m}-\left(S_{\text {fmin }} / \text { So }\right)^{n-2}
$$

Substituting this expression into equation 16 eliminates the term containing the square bracket so that:

$$
\left(S_{f} / S_{0}\right)^{n-2}=\left(Q_{f}+Q_{p}\right)^{\frac{n-2}{m}}-Q_{p}^{\frac{n-2}{m}}+\left(S_{f m i n} / S_{0}\right)^{n-2}
$$

Equation 18 illustrates the important conclusion that once $S_{f m i n}, S_{0}, m$ and $n$ are determined the strength distribution after a proof-test can be determined simply by counting the number of specimens that break during the proof test.

For single region crack growth, equation 18 gives a complete description of the type of probability curve expected for the strength distribution after proof testing. It is straightforward to show that the strength distribution after proof testing is given by a trimodal curve, each part of which corresponds to a

${ }^{*} S_{\text {fmin }}$ approaches zero as the unloading rate becomes vanishingly small (type III distribution ${ }^{7}$ discussed in part $T$ of this paper), and has an upper limit when $S_{\text {fmin }}=\sigma_{p}$ (i.e. infinite unloading rate, for which no crack growth occurs during the proof test, type II distribution ${ }^{7}, 10$ discussed in part 1 of this paper.) 
different range of initial strengths and corresponding failure probability (figure $3 b$ ). When strengths before testing are high, little crack growth occurs during the proof test, and as a consequence, strength degradation resulting from the proof test is slight (fig. 2). In quantitative terms, the strength after the proof test will be much greater than the proof test stress $\left(S_{f} \gg \sigma_{p}\right)$, so that $Q_{f} \gg Q_{p}$. If the final strength is also much larger than the truncation strength $\left(S_{f}>>S_{f m i n}\right)$, then the strength distribution after the proof test (calculated from eq. 18) is given by $\left(S_{f} / S_{0}\right)^{m}=Q_{f}$, which is identical to the initial distribution (eq. 14). This portion of the strength distribution curve is indicated by a slope of $m$ in figure $3 b$.

For an intermediate range of initial cummulative failure probabilities, strength degradation resulting from crack growth significantly alters the strength distribution after proof testing. If the final strength is significantly greater than the truncation strength $\left(S_{f}>>S_{f m i n}\right)$, and if the failure probability after proof testing, $Q_{f}$, is less than the failure probability, $Q_{p}$, calculated from $Q_{p}=\left(\sigma_{p} / S_{0}\right)^{m}$ (i.e. $\left.Q_{f} \ll Q_{p}\right)$, then the strength distribution given by equation 18 can be simplified by expanding $\left(Q_{f}+Q_{p}\right)^{(n-2) / m}$ as a Taylor series. The final distribution for the intermediate probability range is then given by:

$$
\left.Q_{f}=[m / n-2)\right] Q_{p}(m+2-n) / m\left(s_{f} / s_{o}\right)^{(n-2)},
$$

which implies that the strength distribution after proof testing can be represented by a straight line with a slope $m^{\prime}=n-2$ (figure $3 b$ ). Finally, in the lowest probability range, the strength distribution must be truncated so that $S_{f}=S_{f m i n}$, where $S_{f m i n}$ is given by equation (11). 
In summary, the strength distribution after proof testing can be described by two Weibull curves (Figure $3 b$ ): one at higher probabilities having a slope of $\mathrm{m}$; the other at lower probabilities having a slope of $n-2$. As indicated in figure $3 b$, the low probability curve is truncated at a strength given by $S_{\text {fmin }}$.

5. Single Region Crack Propagation: Examples of Strength Degradation Maps and Weibul1 Diagrams

The equations presented in the previous sections will now be illustrated for the special case of single-region crack propagation in soda-1imesilicate glass. Experimentally determined values of $A$ and $n$ were selected to represent crack propagation in air $(50 \% \mathrm{rh})$ and dry nitrogen gas $(20 \% \mathrm{rh})$. To illustrate the effect of unloading rate on strength, two values $(1 \mathrm{MPa} / \mathrm{s}$ and $1000 \mathrm{MPa} / \mathrm{s})$ were used for each environment, the loading rate was conveniently set equal to the unloading rate and the hold time was set equal to zero. The strength/stress axes of the resulting strength degradation maps shown in figures 4 and 5 are represented in terms of the reduced variables $S / S_{0}$ and $\sigma / S_{0}$, where $S$ is the strength, $\sigma$ is the stress and $S_{0}$ is the Weibull strength measured in an inert environment. The time axes in these figures are plotted in terms of the reduced variable $t / T$ where $T$ is the total time of the proof test cycle.

Figure $4 a$ and $b$ illustrate the predicted effect of moist air $\left(50 \% r_{0} h_{0}\right)$ on the strength of soda-lime-silicate glass specimens for the loading conditions just specified. The strength degradation map for a loading rate of $1 \mathrm{MPa} / \mathrm{s}$ (figure 4a) illustrates a number of features discussed in the previous sections: at high initial strengths relatively little strength degradation occurs during the stress cycle; at low initial strengths, the strength decreases relatively rapidly once the stress reaches a sizable fraction of the initial strength. Over a relatively narrow range of initial strengths that separate those specimens that fail from those that survive the proof test, a dramatic 
change in the shape of the strength degradation curve is observed. The strength curve bends over as the unloading cycle begins, and the strength appears to decrease at a relatively constant rate as the stress is decreased further. Specimens with injtial strengths that are just above the critical value survive the proof cycle; initial strengths that are just below critical fail the proof cycle. Note that significant strength degradation occurs for specimens that just pass the proof test and that a significant number of failures can occur during the unloading portion of the proof test cycle. The truncation strength for conditions given for figure $4 a$ was $S_{\text {fmin }}=0.035 \mathrm{~S}_{0}$.

The effect of higher loading rates on strength is shown in figure 4b. As can be seen from this figure increasing the loading rate to $1000 \mathrm{MPa} / \mathrm{s}$ decreases the value of $S_{j}$ that just survives fracture. Also, the value of the truncation stress $S_{\text {fmin }}=0.35 S_{0}$ is increased by one order of magnitude as the loading rate is increased by three orders of magnitude. For tests dry nitrogen (figures $4 c$ and $4 d$ ) strength degradation curves are similar to those just discussed, however because water is not present, strength degradation is less for all levels of initial strength, and far fewer components break during the proof test.

Figure 5 illustrates the effect of environment and loading rate on the strength distribution after proof testing. For all test conditions, the curves obtained for specimens that survive the proof test approaches the curve that represents the initial strength distribution (the straight lines in figure 5). At low probability levels the curves for the proof test survivors approach a slope of $n-2$, as expected. For the test conditions selected, the truncation strength occurs at a value too low to be represented on figure 5 . The effect of loading rate on the strength distribution after proofing can be discerned by comparing figures $5 \mathrm{a}$ and $5 \mathrm{~b}$ for the moist environment. Because far fewer specimens break at the high loading in the moist environment, ( 7 percent for $1000 \mathrm{MPa} / \mathrm{s} \mathrm{Vs}$. 
278 percent for $1 \mathrm{MPa} / \mathrm{s}$ ), the low probability portion of the survival curve shown in figure $5 b$ has shifted to lower strength values relative to the curve in figure 5a. This effect of loading rate on the survival curve is greatly suppressed in dry environments, as can be discerned by the fact that virtually the same survival curve is obtained at low and high loading rates (figure $5 c$ and $5 d$ ). For the same loading conditions, proof testing in dry environments greatly reduces the number of failures during the proof test $(\sim 2.9$ percent at $1000 \mathrm{MPa} / \mathrm{s}$ and 4.5 percent at $1 \mathrm{MPa} / \mathrm{s}$ ). Furthermore since the slope of the survival curve increases at low failure probabilities, the probability of failure at a given strength after proof testing is greatly reduced by using a dry environment for the proof test, thus confirming the importance of environmental control during proof testing.

6. Multi-region Behavior: Examples of Strength Degradation Maps and Weibull Diagrams

Multi-region crack propagation can, in principle, be handled by the same mathematical techniques discussed in Sections 2 and 3 . Equation 7 would be applicable within each region of crack growth, with appropriate values of $A$ and $n$ being used to describe crack growth behavior. As the strength degradation curves passes between two regions of crack growth, boundary conditions require that both the strength and the slope of the strength degradation curve (dS/dt) be continuous. Given the initial strength, equation 6 can be used to estimate either the final strength (if the strength curve does not intersect the boundary line between region $I$ and II), or the strength at intersection of the boundary. Determination of the strength at the intersection with the boundary requires an iterative procedure to be applied to equation 6 , because both the limits of integration of equation 6 and the strength depend on the point of intersection of the strength curve with the boundary. Once the strength at the boundary is determined, 
this same procedure can be repeated to estimate the strength at other boundaries of the strength degradation map. It is worth emphasizing that, depending on the initial strength, a strength degradation curve can either exit from a region of crack growth by going to the next region (i.e., region II to region III), or by going back to the previous region of crack growth, (i.e., region II to region I). Because of these complexities, strength degradation maps are obtained more easily by direct numerical integration of crack propagation data.

The computer routine used here to investigate multiregion crack propagation is based on a direct integration of equation 3, assuming that the rate of crack growth is controlled by equation 4 . Given an initial strength, the crack length can be determined from equation 2 . The stress for crack growth determined from the stress cycle is then used to calculate the crack velocity from equation 4 . For a time increment, $d t$, the change in crack length, da, during dt is determined from the crack velocity, da=vdt. Finally a new length, atda, is used to calculate a new strength, which completes one iteration of the computer cycle. By repeating the calculation many times, the rate of change of strength with time can be determined. At the end of each cycle, a comparison is made between the calculated strength and boundary-value conditions (see figure $2 b)$ to determine the appropriate crack growth parameters that are applicable (i.e., the correct region of crack growth). If the condition $S=\sigma$, is attained fracture is assumed to occur. This numerical method was used as a subroutine in a larger program to obtain strength degradation maps, Weibull diagrams, and strength histograms. These diagrams demonstrate the effects of multi-region crack propagation on the strength of materials. As will be shown in a comparison of multi-region maps with their counterparts described in figure (4), region II crack growth behavior has a significant effect on the appearance of these diagrams. 
The main features of strength degradation in a moist environment (air, 50 percent $r . h_{.}$) are shown in fiqures 6-8. When specimens are loaded and unloaded relatively slowly $(1 \mathrm{MPa} / \mathrm{s})$, both the strength degradation map (figure 6a) and the Weibull plot (figure 6b) look similar to those obtained for single mode propagation in moist nitrogen gas, (50 percent $r . h$. , figures $4 a$ and $5 a$ ). By contrast, at high loading rates $(1000 \mathrm{MPa} / \mathrm{s})$, the strength degradation map (figure $7 \mathrm{a}$ ) and the Weibull diagram (figure 7b) are nearly identical to those obtained for single mode propagation in dry nitrogen. Thus, the distribution after proof testing seems to be determined mainiy by region I crack growth when the rate of loading is slow, and by region III crack growth when the rate of loading is high.

At intermediate loading rates, region II crack growth behavior dominates the shape of the strength distribution curves of specimens that survive the proof-test cycle. As illustrated in figure $8 \mathrm{a}$, the effect is most pronounced when the slope of the strength degradation curve is slightly greater than the slope of the line that represents the boundary between region I and region II crack propagation. From equation 5 , we see that once the strength curve enters region II, its curvature changes from negative (large $n$ ) to positive $(n=0)$, so that the slope decreases as $S$ decreases, with the consequence that components with a range of initial strengths that normally would have failed during the load cycle (for single region crack growth) now survive, but with a greatly reduced strength. Because of this behavior, the Weibull curves (figure 8b) are severely distorted. Instead of consisting of two straight lines with a truncation stress at low probabilities (fig. $3 b$ ), the Weibull curve exhibits a large plateau which indicates a constant cumulative failure probability for a fairly wide range of final strengths, $S_{f}$. Therefore, the probability of finding specimens with strengths that 1 ie 
within the strength range of the plateau is ssmall. This plateau in the Weibull curve suggests a bimodal strength distribution with a small peak in the distribution at low levels of strength. This type of distribution is potentially dangerous for materials that are intended for structural applications.

The shape and position of the plateau shown in figure $8 b$, is effected by both the stress cycle parameters and the crack propagation parameters. Although the probability level of the plateau is found to vary as $\sigma_{p}$ is changed, the truncation strength is unaffected by $\sigma_{p}$, provided the stressing rate remains constant (figure 9). This result is consistent with the discussion in section 2 and with equations 10 and 12, which are also applicable to multi-region crack growth. Increasing the stressing rate almost completely eliminates the effect of region II crack propagation (figure $7 b$ ). Conversely, decreasing the stressing rate suppresses the plateau to low probability levels (so that it does not appear in the diagram). The effect of region II crack propagation on the strength distribution is enhanced as the width of region II is increased. Here, the main effect of Region II crack growth on the Weibull curve is to increase the range of stresses over which the plateau occurs.

With regard to proof testing as a method of assuring component reliability, a disturbing aspect of region II crack propagation is that, for equivalent failure probabilities, portions of the strength distribution after proof testing lie at lower strength levels than those given by the initial distribution, resulting in significant probabilities of failure at low stresses after proof testing. This effect occurs for both dry test environments (fig. 10) and moist test environments (fig. 8b). The effect can result in either a significant strength degradation or an apparently unchanged strength distribution as a result of the proof test (high probability region of figure $8 b)$. Effects such as these have been 
reported in Part I of this study and have a plausable explanation in terms of region II crack propagation. For practical purposes, elimination of these effects can be accomplished most easily by increasing the rate of unloading during a proof test. Thus, even for a relatively moist environment, rapid unloading (figure $7 \mathrm{~b}$ ) leads to a distribution after proof testing that is sharply truncated and is better than the initial distribution at all probability levels. Equation $(10)$, with $\sigma_{\text {imin }}=\sigma_{p}$, provides a quantitative estimate of the unloading rate needed for effective truncation of the strength distribution curve in a moist environment such as air. ${ }^{7}$

As a final comment, we refer to the discussion at the end of Part I of this paper, and note that the theory presented in this part provides the basis for understanding strength degradation of ceramic materials. The theory has been used in Part I to explain the general shape of strength distribution resulting from proof testing. The fact that detailed agreement between theory and some experiments was not obtained suggests that our understanding of subcritical crack growth in specimens that contain small cracks (e.g. $<10 \mu \mathrm{m})$ is not complete, and requires further research. The discussions presented in this part of the paper should help in interpreting any new data. Acknowledgements

Two of the authors (E. R. Fuller, Jr. and S. M. Wiederhorn) are grateful for the support of the Department of Energy, Fossil Fuel Utilization Division; the other two (J. E. Ritter, Jr. and P. B. Oates) are grateful for the support of the National Science Foundation, contract DMR-77-05647. 
1. S. M. Wiederhorn, "Mechanisms of Subcritical Crack Growth in Glass," pp 549-580 in Fracture Mechanics of Ceramics, Vol. 4, Edited by $R$. C. Bradt, D. P. H. Hasselman, and F. F. Lange, Plenum Publishing Co., New York (1978).

2. S. M. Wiederhorn, "Subcritical Crack Growth in Ceramics," pp. 613-646 in Fracture Mechanics of Ceramics, Vol. 2, Edited by R. C. Bradt, D. P. H. Hasselman and F. F. Lange, Plenum Publishing Co., New York (1974).

3. John E. Ritter, Jr., "Engineering Design and Fatigue Failure of Brittle Materials," pp 667-686 in ref. 1 .

4. S. H. Wiederhorn, "Influence of Water Vapor on Crack Propagation in Soda-Lime Glass," J. Am. Ceram. Soc. 50, 407-414 (1967).

5. A. G. Evans, "Analysis of Strength Degradation after Sustained Loading," J. Am. Ceram. Soc., 57, 410-411 (1974).

6. A. G. Evans and E. R. Fuller, "Crack Propagation in Ceramic Materials under Cyclic Loading Conditions," Met. Trans. 5, 27-33 (1974).

7. A. G. Evans and E. R. Fuller, "Proof Testing - The Effects of Slow Crack Growth," Mat. Sci. and Engr., 19, 69-77 (1975).

8. A. G. Evans and H. Johnson, "The Fracture Stress and Its Dependence on Slow Crack Growth," J. Mat. Sci. 10, 214-222 (1975).

9. A. G. Evans, "Slow Crack Growth in Brittle Materials under Dynamic Loading Conditions," Inst. J. Fract., 10, 251-59 (1974).

10. A. G. Evans and S. M. Wiederhorn, "Proof Testing of Ceramic Materials - An Analytical Basis for Failure Prediction," Int. J. Fract. Mech., 10, 379-92 (1974).

11. S. M. Wiederhorn, "Reliability, Life Prediction and Proof Testing of Ceramics," High-Performance Applications, J. J. Burke, A. E. Gorum, and R. N. Katz editors, Brook Hill Publishing Co., Chestnut Hill, Mass. (1974).

12. W. Weibul1, "A Statistical Distribution Function of Wide Applicability," J. App1. Mech., 19, 293-97 (1951).

13. N. R. Mann, R. E. Shafer and N. D. Singpurwallee, Methods for Statistical Analysis of Reliability and Life Data, John Wiley \& Sons, New York (1974). 


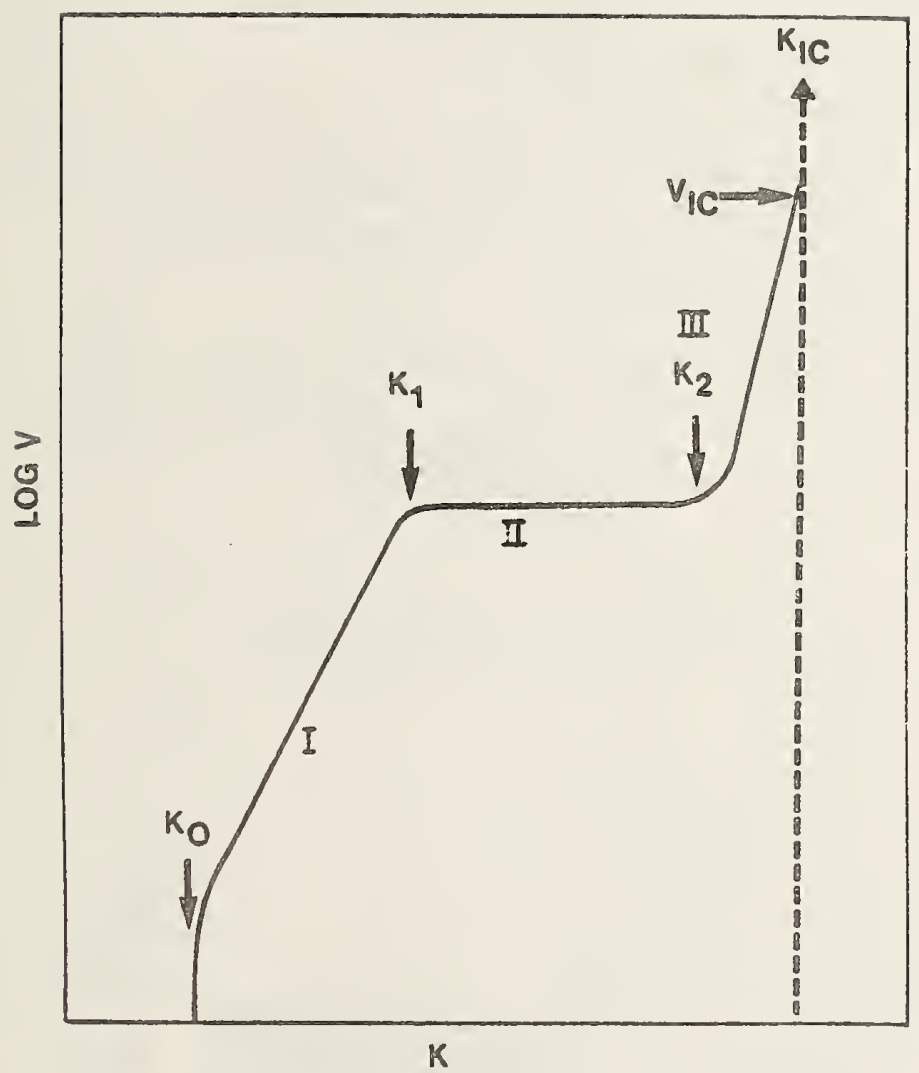

1. Dependence of crack velocity on applied stress intensity factor. Schematic diagram of crack velocily data indicating three regions of crack growth. Boundaries of these three reglons are given by specific values of $\mathrm{K}_{I}\left(\mathrm{~K}_{0}, \mathrm{~K}_{1}, \mathrm{~K}_{2}, \mathrm{~K}_{I C}\right)$ and by a critical value of the crack velocity $\left(\mathrm{V}_{\mathrm{IC}}\right)$. 

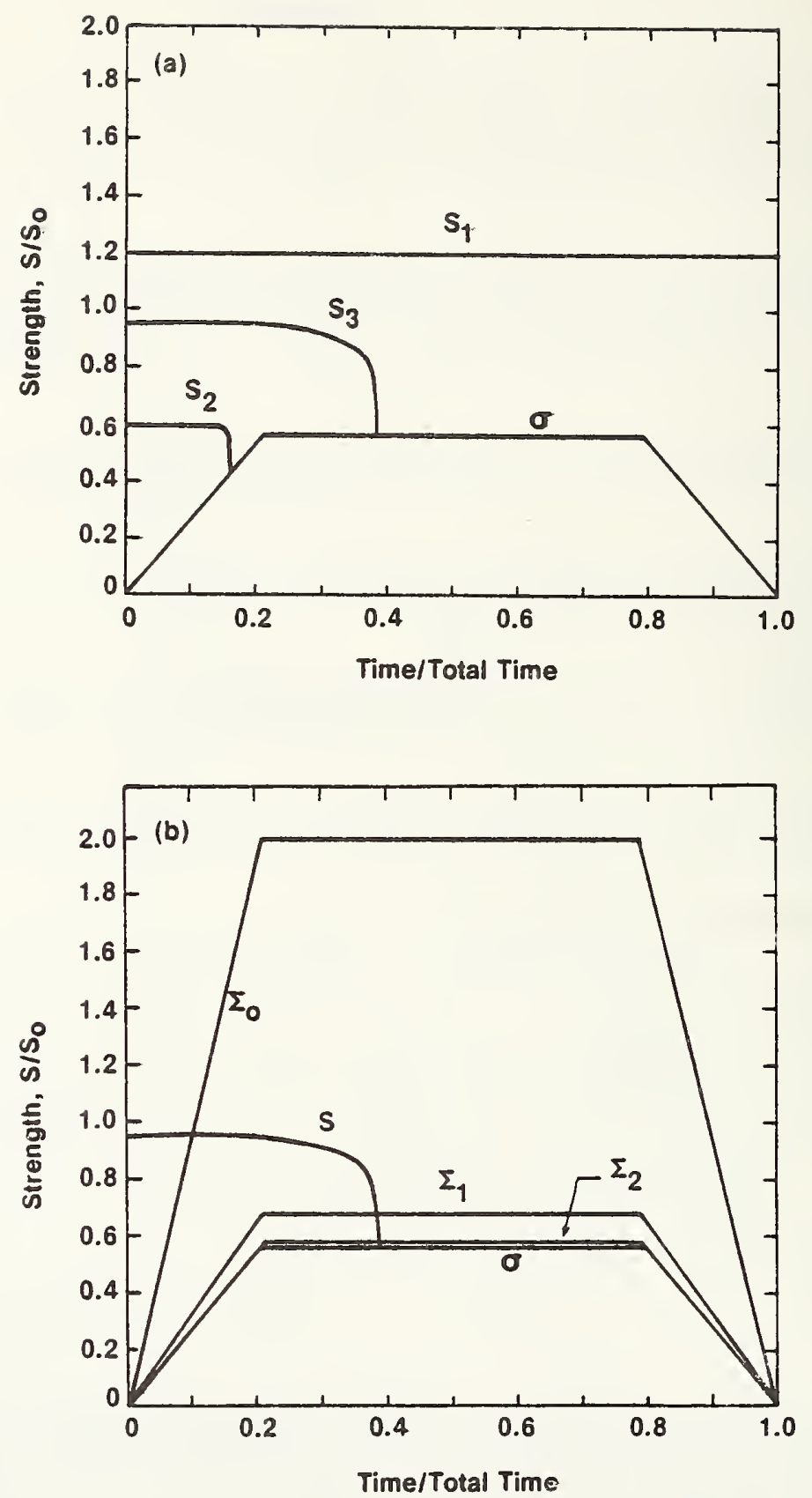

2. Schematic diagram of strength degradation maps for soda-lime-silicate glass. (a) Single region crack growth. Curve labeled $\sigma$ gives the applied stress as a function of time. Curves labeled $\mathrm{S}_{1}, \mathrm{~S}_{2}, \mathrm{~S}_{3}$ give the strength as a function of time starting at different initial strength levels. (b) Three regions of crack growth (as in figure 1). Curves labeled $\Sigma_{0}, \Sigma_{1}, \Sigma_{2}$ and $\sigma$ in this figure correspond to $\mathrm{K}_{0}, \mathrm{~K}_{1}, \mathrm{~K}_{2}$, and $\mathrm{K}_{\mathrm{IC}}$ of figure 1 . The curve labeled $\mathrm{S}$ gives the strength degradation as a function of time. 


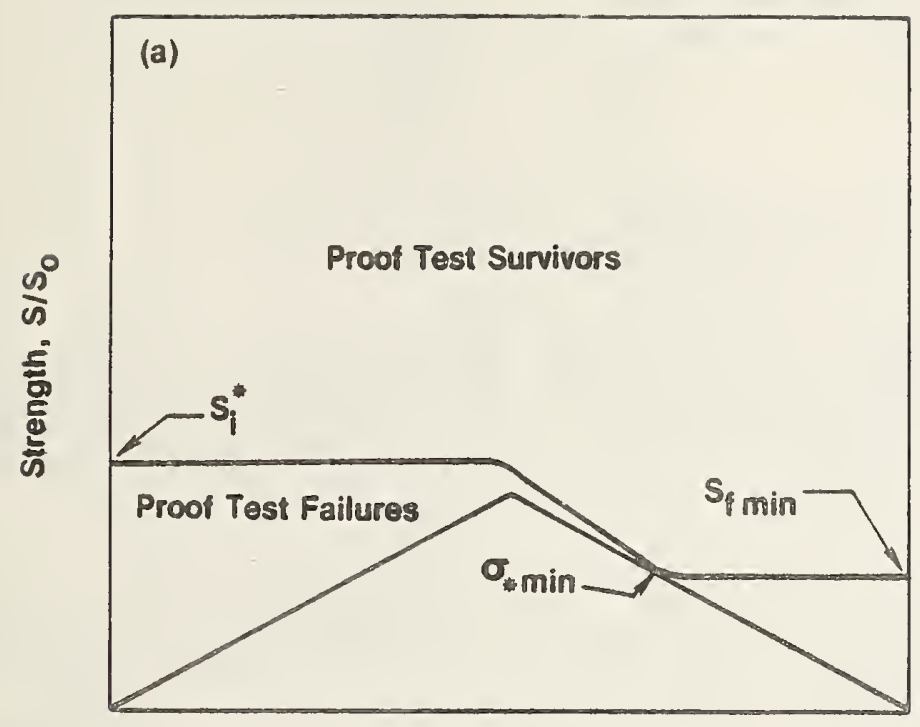

Time/Total Time

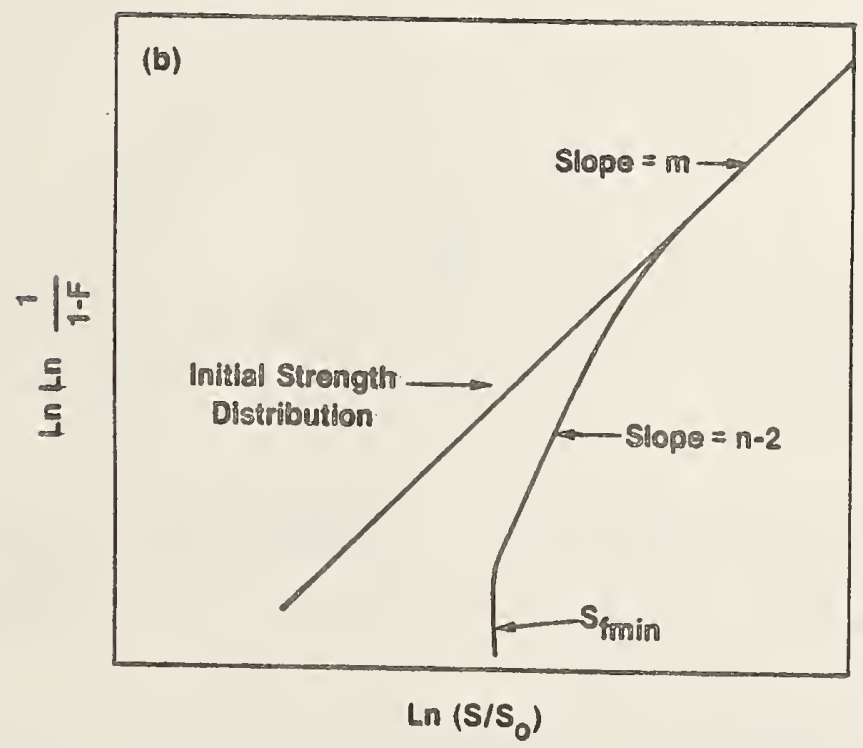

3. Single region crack propagation. (a) Definition of critical initial strength, St, minimum failure stress, $\sigma_{* \min }$, and minimun strength, $\mathrm{S}_{\mathrm{fmin}}$, after the proof test. Specimens with initial strengths greater than $\mathrm{S}_{1}$ will survive, while those with strengths less than Sil will fail. Equal loading and unloading rates during the proof test are assumed in this diagram. (b) Theoretical strength distribution after proof testing. The curve is a graphical representation of equation 18. As discussed in the text, the truncation strength depends only on the rate of unloading, $\dot{\sigma}_{u}$, the critical stress intensity factor, $\mathrm{K}_{\mathrm{IC}}$ and the crack propagation parameters, $\mathrm{n}$ and $\mathrm{A}$. 

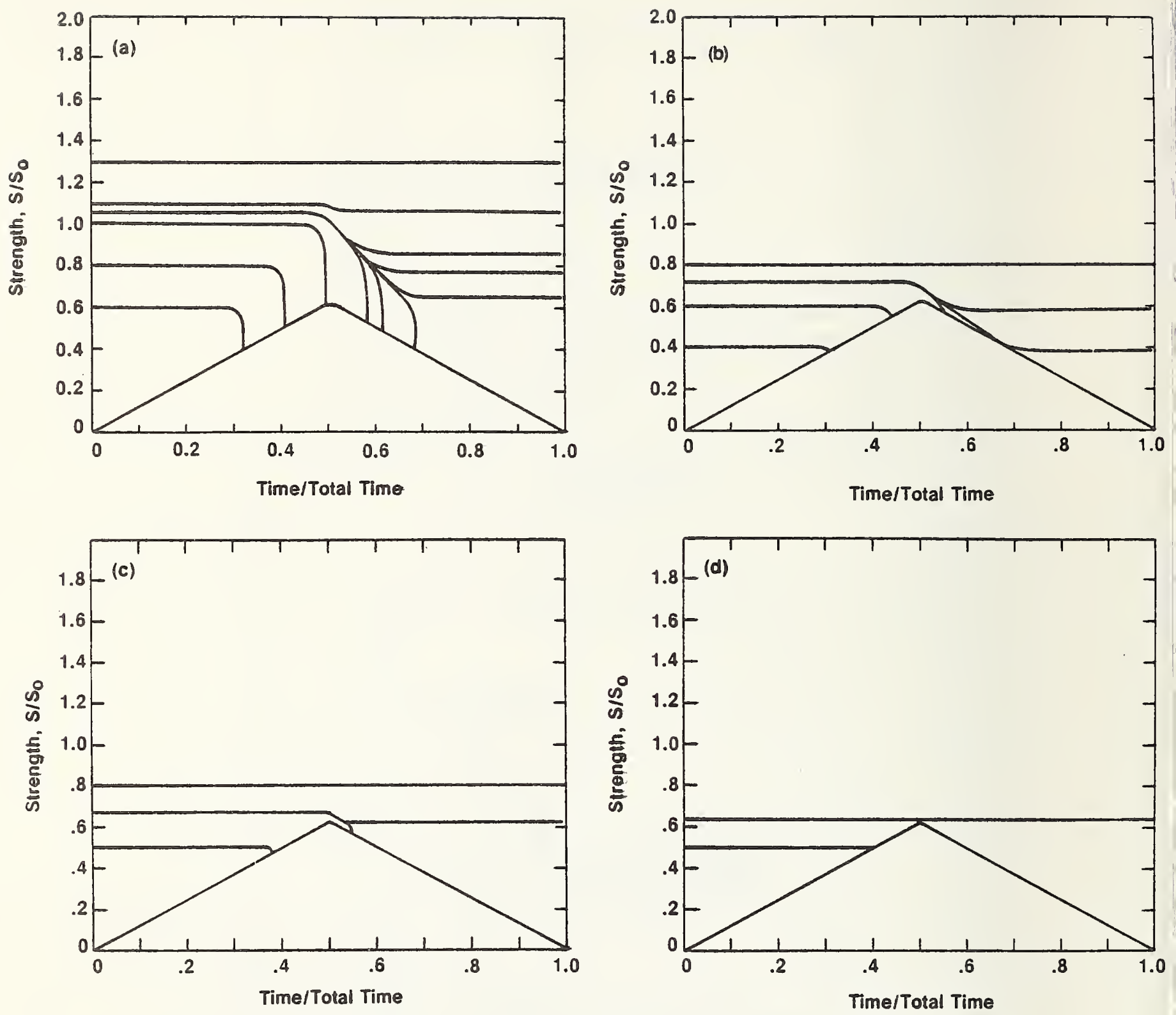

4. Region 1 crack growth: schematic diagrams of strength degradation maps for soda-lime-silicate glass. (a) loading rate: $1 \mathrm{MPa} / \mathrm{s}$. Test in air; $50 \%$ r.h. $(\mathrm{n}=19.7, \ln \mathrm{A}=-271.9)$ (b) Loading rate: $1000 \mathrm{MPa} / \mathrm{s}$. Test in air, $50 \% \mathrm{r.h}$. (c) loading rate: $1 \mathrm{MPa} / \mathrm{s}$. Test in dry air, $0.01 \% \mathrm{r.h} . \quad(\mathrm{n}=120.9$, $\ln A=-1641.4)$ (d) laading rate: $1000 \mathrm{MPa} / \mathrm{s}_{\text {, }}$ dry air, $0.01 \%$ $\mathrm{r} . \mathrm{h} . \mathrm{I}_{1 / 2} \mathrm{~m}=7.7$; So $=126.9 \mathrm{MPa} ; \mathrm{K}_{0}=0 \mathrm{MPa}-\mathrm{m}^{\frac{1}{2}} ; \mathrm{K}_{\mathrm{IC}}=0.75$ $\mathrm{MPa}-\mathrm{m}^{\frac{1}{2}}, \sigma_{p}=0.65 \mathrm{So}$. 

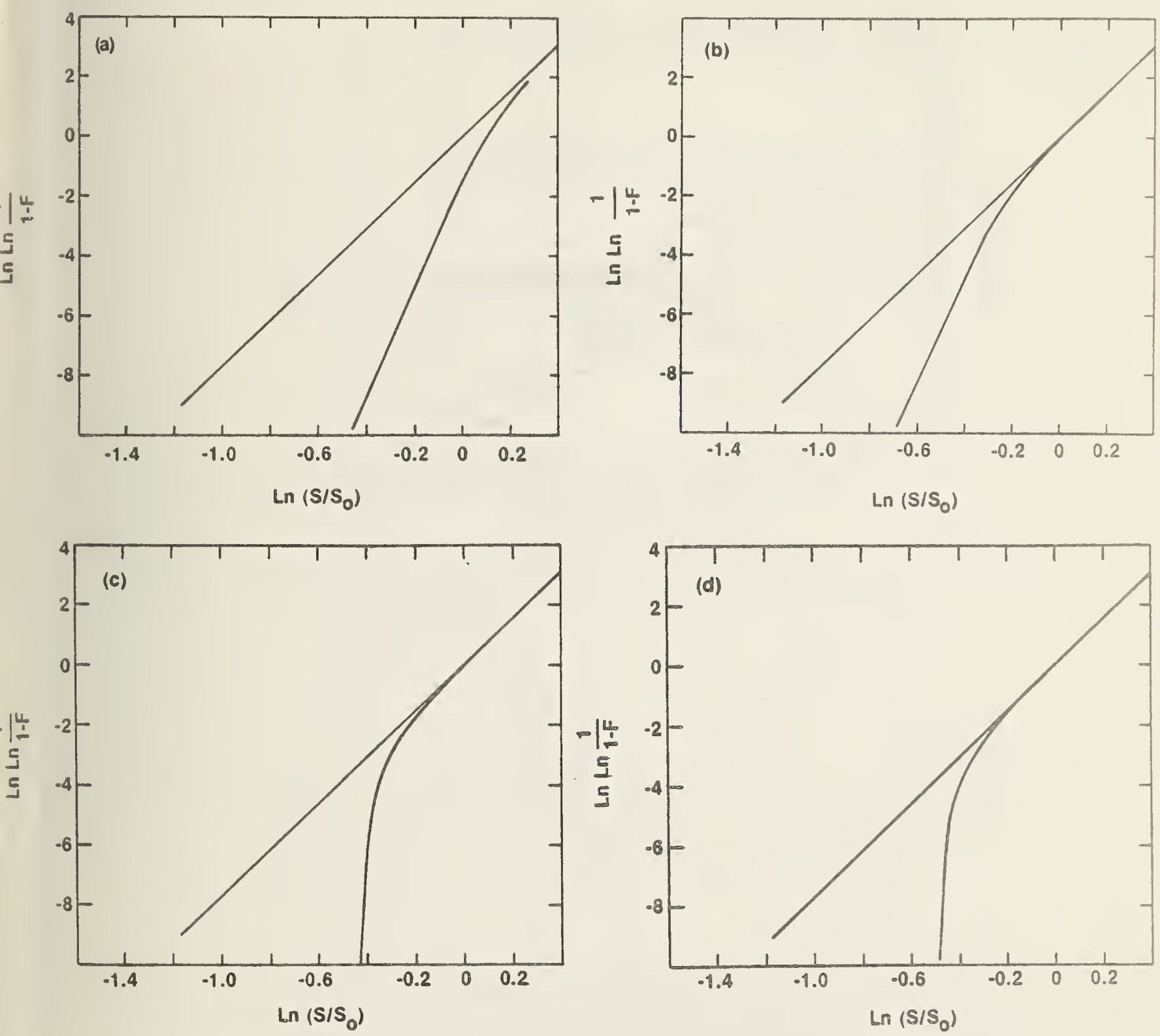

5. Region 1 crack growth: schematic diagram of strength distribution after proof testing for soda-lime-silicate glass. (a) loading rate $1 \mathrm{MPa} / \mathrm{s}$. Test in air, $50 \% \mathrm{r} . \mathrm{h}$. (b) loading
rate $1000 \mathrm{MPa} / \mathrm{s}$. Test in air $50 \% \mathrm{r} . \mathrm{h}$. (c) loading rate $1 \mathrm{MPa} / \mathrm{s}$. Test in air $0.01 \% \mathrm{r.h}$. (d) loading rate $1000 \mathrm{MPa} / \mathrm{s}$. Test in air $0.01 \%$ r.h. Experimental constants used for this figure are given in figure 4. 

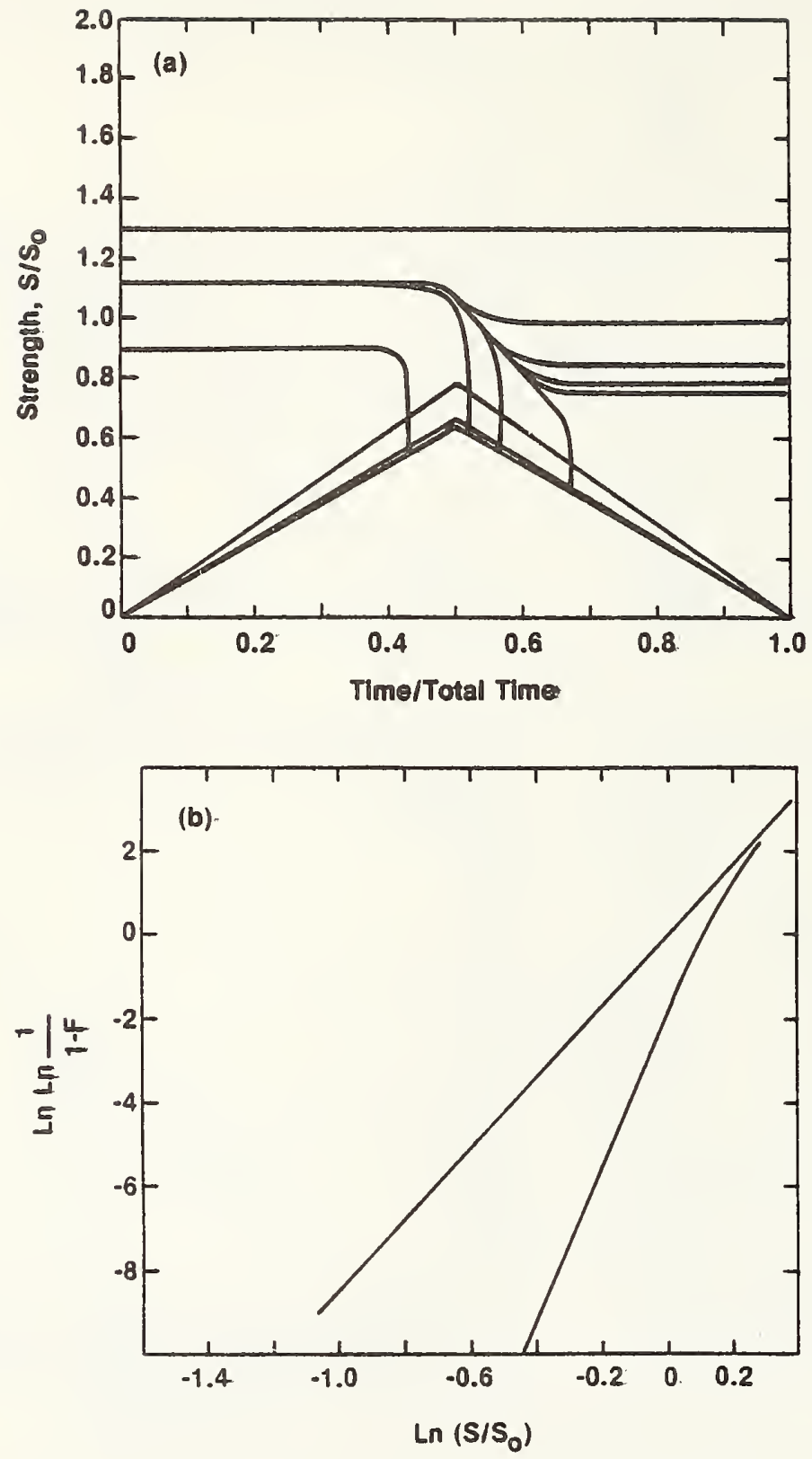

6. Multiregion crack growth: Atr 50\% r.h., loading rate: $1 \mathrm{MPa} / \mathrm{s}$. (a) strength degradation map. (b) Strength distribution after proof test. Crack growth parameters for figures 6 through 9: region $1, \mathrm{n}=19.7, \ln \mathrm{A}=-271.9$; region $2, \mathrm{v}=1 \times 10^{-4}$ $\mathrm{m} / \mathrm{s}$; region $3, \mathrm{n}=120.9$, In $\mathrm{A}=-1641.4$. Weibull parameters for figures 6 through $9: \mathrm{S}_{0}=137.9 \mathrm{MPa}, \mathrm{m}=8.4$. pther constants for figures 6 through $9: \mathrm{K}_{\mathrm{IC}}=0.75 \mathrm{MPa}-\mathrm{m}^{\frac{1}{2}} ; \mathrm{K}_{\mathrm{O}}=$ $0 \mathrm{MPa}-\mathrm{m}^{2} ; \sigma_{\mathrm{p}}=0.65 \mathrm{~S}_{\mathrm{o}}$. 

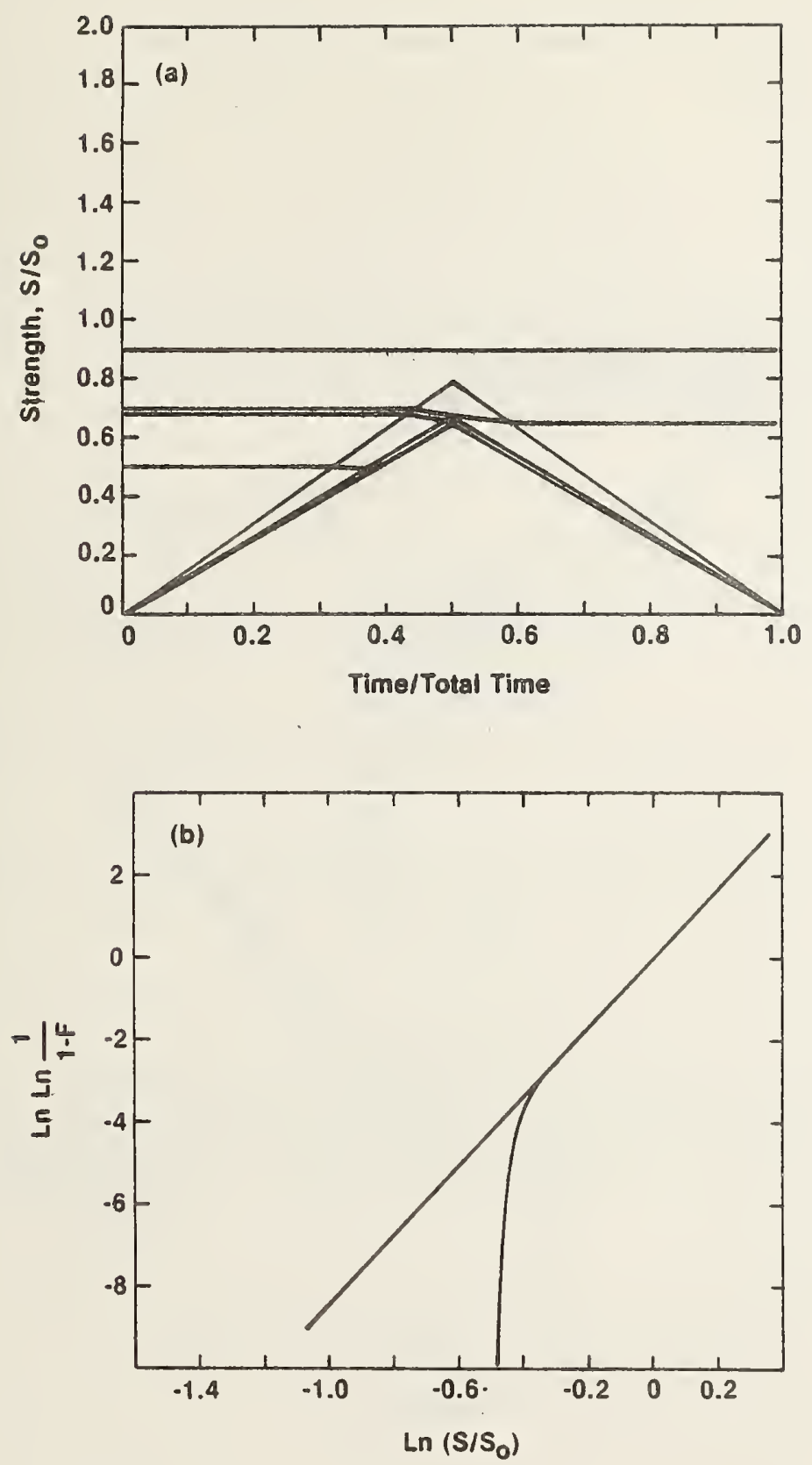

7. Multiregion crack growth: Air 50\% r.h., loading rate: $1000 \mathrm{MPa} / \mathrm{s}$. (a) Strength degradation map, (b) Strength distribution after proof testing. 

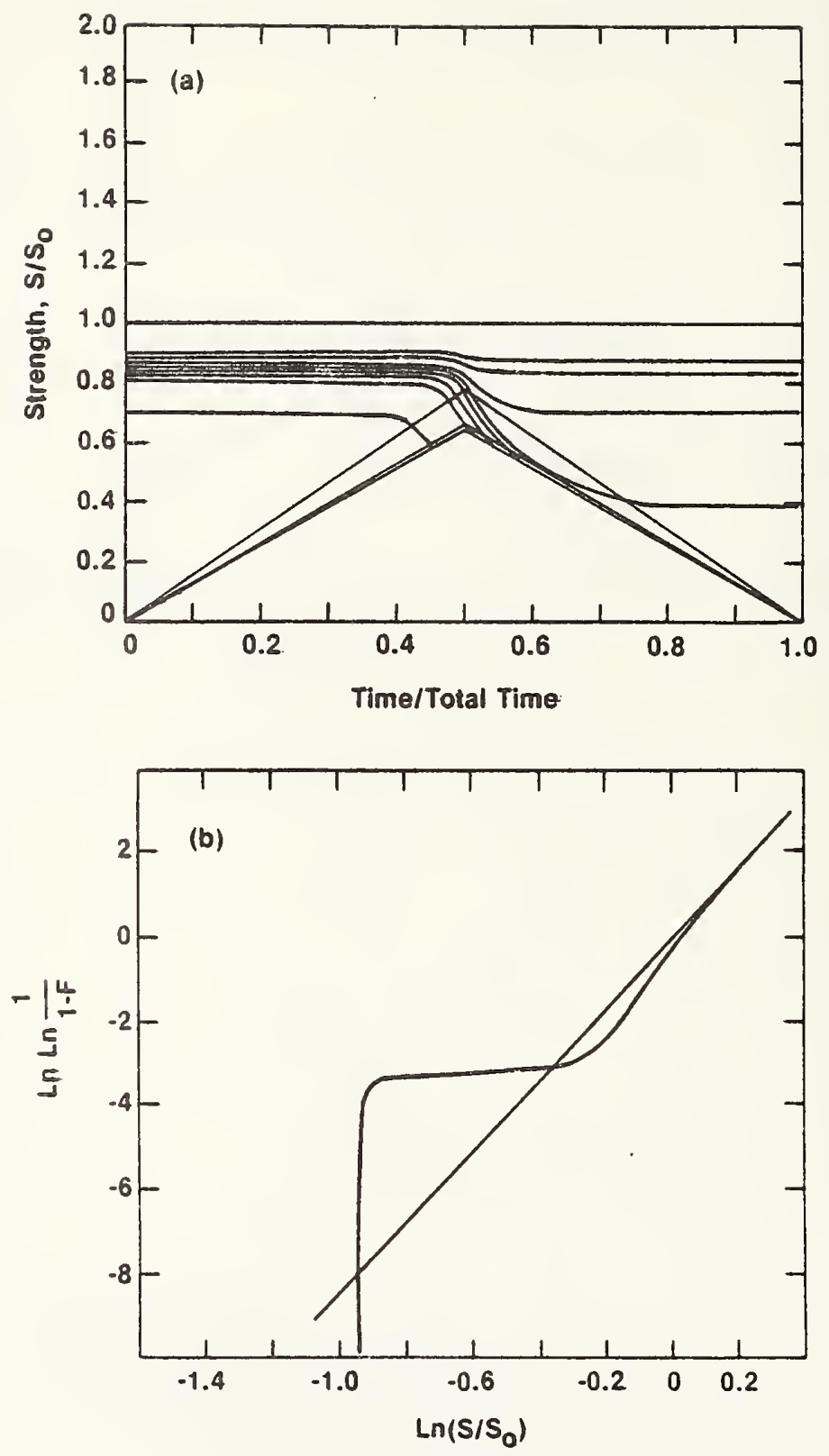

8. Multiregion crack growth: Air 50\% r.h., loading rate: $100 \mathrm{MPa} / \mathrm{s}$. (a) strength degradation map; (b) strength distribution after proof testing. 


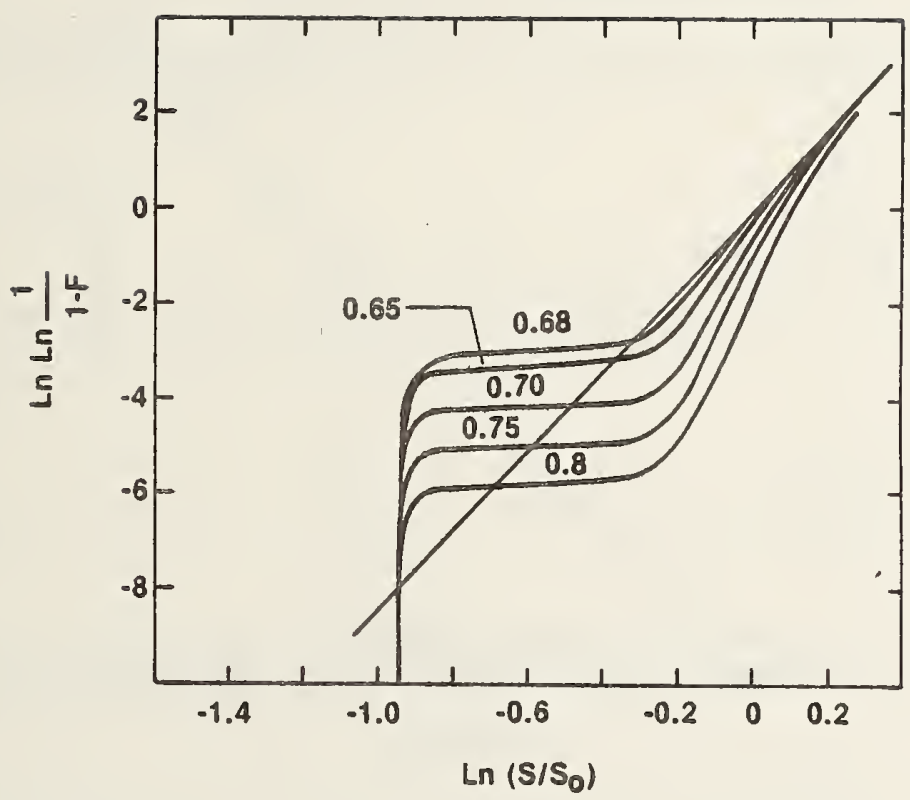

9. Dependence of strength distribution after proof test on proof test stress, $\sigma_{p}$, indicated by the numbers associated with each curve. Loading rate: $100 \mathrm{MPa} / \mathrm{s}$. Air, 50\% r.h. 


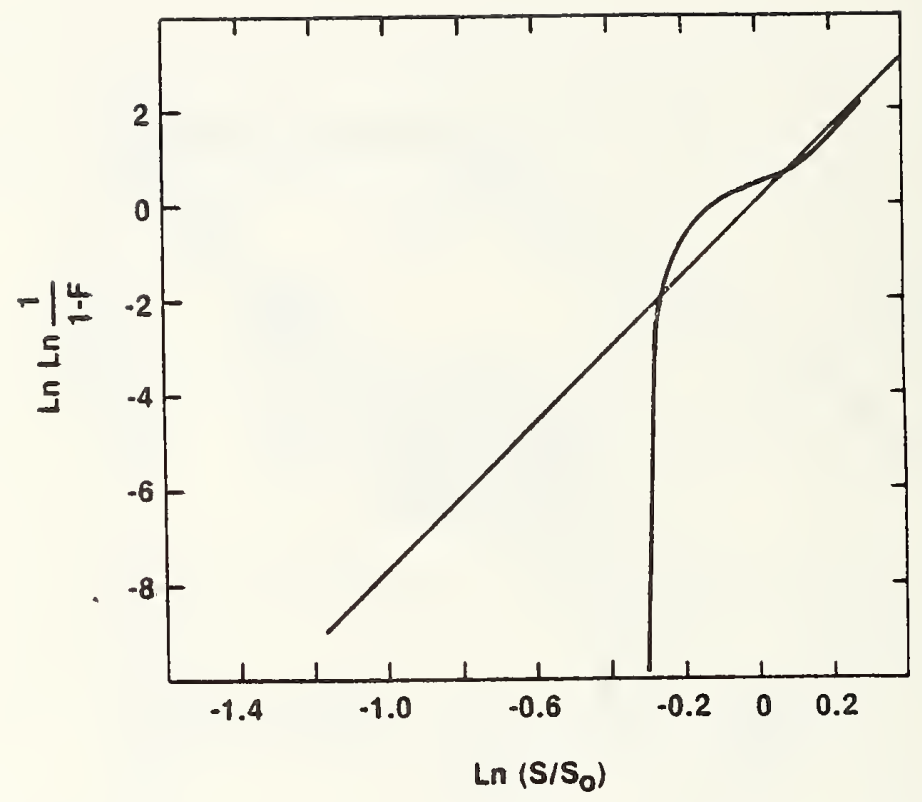

10. Strength distribution after proof test: air $0.01 \%$ r.h.; loading rate, $1 \mathrm{MPa} / \mathrm{s} ; \sigma_{\mathrm{p}}=0.82 \mathrm{~S}$. Crack growth parameters: region $1, n=19.7$, InA $=-296.5$; region 2 , $\mathrm{v}=1.5 \times 10^{-7} \mathrm{~m} / \mathrm{s}$; region $3, \mathrm{n}=120.9,1 \mathrm{nA}=-1641.4$. Weibull parameters: $\mathrm{S}_{0}=126.9 \mathrm{MPa} / \mathrm{s} ; \mathrm{m}=7.7$. 


\begin{tabular}{|c|c|}
\hline $\begin{array}{c}\text { U.S. OEPT. OF COMM. } \\
\text { BIBLIOGRAPHIC DATA } \\
\text { SHEET }\end{array}$ & $\begin{array}{c}\text { 1. PUBLICATION OR REPORT NO. } \\
79-1944\end{array}$ \\
\hline
\end{tabular}

4. TITLE AND SUBTITLE

Proof Testing of Ceramics: II. Theory

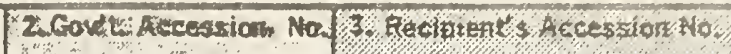

P. B. Oates
6. Pertorning Organization: Code

5. Publication Date

8. Performing Organ. Report No.

\section{AUTHOR(S)}

S. M. Wiederhorn, J. E. Ritter, Jr. and

$\frac{\text { 2. R. FuIler, Jr., S. M. Wiederhorn }}{\text { 9. PERFORMING ORGANIZATION NAME AND ADDRESS }}$

NATIONAL BUREAU OF STANDARDS

DEPARTMENT OF COMMERCE

WASHINGTON, DC 20234

12. SPONSORING ORGANIZATION NAME AND COMPLETE ADDRESS (Street, City, State, ZIP)

Department of Energy

Washington, D. C.

14. Spansoring Agency Codis

\section{SUPPLEMENTARY NOTES}

- Document describes a computer program; SF-185, FIPS Software Summary, is attached.

16. ABSTRACT (A 200-word or less tactual sumerery of most significant information. If document includes a significant bibliography of literature survey, mention it here.)

Theoretical estimates are made of strength distributions after proof testing. Assuming that the crack velocity can be expressed as a power function of the stress intensity factor, $\mathrm{v}=\mathrm{A} \mathrm{K}^{\mathrm{n}}$, an analysis of the amount of strength loss during a load cycle is presented for single-region crack propagation. For multi-region crack propagation, a numerical analysis is used to describe strength loss. In both analyses, the effects of environment and loading rate are studied. For single-region crack propagation, the strength after proof testing can be represented by two Weibull curves, one with a slope of $m$ at high cumulative failure probability levels, the other with a slope of $n-2$ at low failure probability levels. Truncation of the strength distribution always occurs as the result of proof testing; the truncation strength depends on the rate of unloading. Multi-region crack propagation results in a more complicated strength distribution after proof testing. Bimodal strength distributions occur as a consequence of region II type crack growth ( $i . e . n=0$ ). Theoretical results confirm experimental findings that proof tests must be conducted at rapid unloading rates and with good environmental control to be effective.

17. KEY WORDS (six to twelve entrieo; alphabotical order; capitalize only the first letrer of the first key word unless a proper namo: soparated by semicolons)

Crack growth; fracture; fracture mechanics; proof testing; statistics; strength.

Unlimited

— For Official Distribution. Do ivot Release to NTIS

- Order From Sup. of Doc., U.S. Government Printing Office, Wasinington, DC 20402, SO Stock No. SNOOO3-003-

X Order From National Technical Information Service (NTIS), Springfield, VA. 22161

\begin{tabular}{|l|c|}
\hline $\begin{array}{l}\text { 19. SECURITY CLASS } \\
\text { ITHIS REPORTI } \\
\text { UNCLASSIFIED }\end{array}$ & $\begin{array}{c}\text { 21. NO. OF } \\
\text { PRINTED PAGES }\end{array}$ \\
\hline $\begin{array}{l}\text { 20. JECURITY CLASS } \\
\text { (THIS PAGE) }\end{array}$ & $\begin{array}{c}\text { 22. PIICE } \\
\text { UNCLASSIFIED }\end{array}$ \\
\hline
\end{tabular}



NBSIR $80-2047$

APPLICATION OF FRACTURE

MECHANICS IN ASSURING AGAINST

FATIGUE FAILURE OF CERAMIC

COMPONENTS

J.E. Ritter

Mechanical Engineering Department

University of Massachusetts

Amherst, MA 01003

S.M. Wiederhorn, N.J. Tighe, and E.R. Fuller, Jr.

National Bureau of Standards

Fracture and Deformation Division

National Measurement Laboratory

Center for Materials Science

U.S. Department of Commerce

Washington, DC 20234

Published in:

Ceramics for High Performance Applications - III Reliability

E.M. Lenor, R.N. Katz, and J.J. Barke, ed.

Plenum Pubi. Corp., 1981

Army Materials Technology Conference Series

Vol. 6 

APPLICATION OF FRACTURE MECHANICS IN ASSURING AGAINST FATIGUE

FAILURE OF CERAMIC COMPONENTS

J. E. Ritter, Jr。

University of Massachusetts

Amherst, MA. 01003

S. M. Wiederhorn, N. J. Tighe and E. R. Fuller, Jr.

Fracture and Deformation Division

National Bureau of Standards

Washington, D. C. 20234

\section{INTRODUCTION}

The use of ceramics in high performance applications offers a challenge to scientists and engineers: the challenge of designing structural components with brittle materials. Design problems arise for two reasons when brittle materials are used as structural components: 1. The strength of brittle materials is not a well defined quantity, but can vary widely depending on the material; 2 . The strength of brittle materials is time dependent so that these materials often exhibit a time delay to failure. This time dependence and scatter of strength so typical of most ceramic materials occurs because of the presence of defects such as cracks or crack-like flaws in these materials. When subjected to an applied tensile stress, these defects act as stress concentrators and fracture occurs when the applied stress intensity factor reaches a critical value. Scatter in the strength of ceramic materials is a consequence of the scatter in the size of the most critical defect in the ceramic. The time dependence of strength results from subcritical crack growth which gradually lengthens the crack until it reaches critical dimensions, at which time failure occurs. The time delay to failure is the time required for the crack to go from a subcritical to a critical size. 
Methods of dealing with design problems involving fatigue of ceramic materials have been developed over the past 10 years through the application of the techniques and concepts of fracture mechanics $(1-3)$. Since fracture mechanics techniques can be used to characterize both the conditions for subcritical crack growth and the conditions for crack instability, they can be used for purposes of design to estimate the allowable applied stress and the expected lifetime for a given component. This is accomplished by estimating the initial crack size in a ceramic component and the time required for the crack to grow from its Initial size to a final critical size. Several mutually independent techniques have been developed recently to provide these types of estimates. Since these techniques promise to revolutionize the way in which structural components made of ceramic materials are designed, a complete understanding of these techniques, their application, and their limitations will be necessary to use them correctly.

This paper will review the application of fracture mechanics theory to the prevention of delayed failure of ceramics. Three successful applications of this theory of assuring the mechanical reliability of ceramics are discussed in order to demonstrate the viability of the theory for purposes of engineering design. Finally, a description is presented of practical limitations of the theory with regard to heat engine application. Methods of overcoming these limitations through modification of test procedures, and application of statistical theory are then presented.

\section{THEORY}

Since fracture mechanics concepts can be used to characterize both the conditions for subcritical crack growth and the conditions for crack instability, they can be used to predict the failure of ceramic materials under given service conditions. This is accomplished by estimating the initial crack size in a ceramic component and the time for the crack to grow from its initial size to a final critical size: As the crack grows to its critical size, the crack velocity (V) is assumed to be dependent on the applied stress intensity factor $\left(K_{I}\right)$ by $(1)$ :

$$
V=A K_{I}^{N}
$$

where $\mathrm{A}$ and $\mathrm{N}$ are crack growth constants that depend on the environment and material composition. From Equation ( 1 ) and the relation $\sigma=K_{I C} / Y \sqrt{a}$, it can be shown that the time to failure $\left(t_{f}\right)$ under constant applied tensile stress $\left(\sigma_{a}\right)$ is (3):

$$
t_{f}=B s^{N-2} \sigma_{a}^{-N}
$$


where $B=2 /\left(\mathrm{AY}^{2}(n-2) K_{I C}{ }^{N-2}\right), K_{I C}=$ critical stress intensity factor, and $S=$ fracture strength in an inert environment where no subcritical crack growth occurs prior to fracture. From its definition, $B$ is a crack propagation constant that depends on the environment and material composition.

In Equation (2), $t_{f}$ represents the time required for a flaw to grow from an initial, subcritical size, to dimensions critical for catastrophic propagation; $B$ and $N$ are the constants that characterize this subcritical crack growth. The initial flaw size is characterized in Equation (2) by the fracture strength in an inert environment*. From Equation (2) it is seen that the time to failure decreases with increasing stress, i.e. fatigue under a static stress.

Also from Eq. (1), a relationship can be derived between the fracture strength $\sigma_{f}$ and stressing rate $\dot{\sigma}$. In this case flaws grow from subcritical to critical size under constantly increasing stress. The results of this analysis is $(1-3)$ :

$$
\sigma_{f}^{N+1}=B(N+1) s^{N-2} \circ
$$

where $B$ and $N$ are the same fatigue constants as in Eq. (2). From Equation (3) it is seen that fracture strength decreases with decreasing stressing rate since the flaws have more time to grow. This behavior is known as dynamic fatigue, i.e. fatigue under constant stressing rate conditions.

The probability of failure (F) for a given lifetime and applied stress can be obtained from Equation (2) by expressing the inert strength in terms of its failure probability distribution. Generally, the inert strength distribution of ceramics can be approximated by the Weibull relationship (3):

$$
\text { In } \ln \frac{1}{I-F}=m \ln \frac{s}{S_{0}}
$$

where $m$ and $S$ are empirical constants evaluated by a fit of the strength data. Likewise, the strength distribution at a fixed stressing rate can be obtained by substituting Equation (4) into Equation (3).

Because ceramics exhibit a wide spread in strength values (m is typically $4-8$ ), the allowable stress in service is quite

*The initial crack size, $a$, can be calculated, if desired, frgm
the well known fracture mechanics relationship: $a=k / \mathrm{r}^{2}$, the well known fracture mechanics relationship: $a=K I C / Y^{2} S^{2}$,
where $Y$ is a constant that is determined by the geometry of the specimen and the crack. In subsequent discussion, a is assumed to be small relative to component dimensions so that $Y$ is a single valued constant. 
low if low failure probabilities are required. Proof testing offers one means of increasing the design stress for ceramics (1-3). The value of proof testing is that it characterizes the largest effective flaw possible in a tested component, since any larger flaws would have caused failure during the proof test.

Assuming that flaw growth during the proof test cycle is given by Equation (1) (i.e. one region of crack growth) and that the initial inert strength distribution can be characterized by Equation (4), the inert strength after proof testing $\left(\mathrm{S}_{a}\right)$ is given by (4):

$$
\begin{aligned}
\left(S_{a} / S_{0}\right)^{N_{p}-2} & =\left(-\ln \left(1-F_{a}\right)-\ln \left(1-F_{p}\right)\right)^{\left(N_{p}-2\right) / m} \\
& -\left(-\ln \left(1-F_{p}\right)\right)^{\left(N_{p}-2\right) / m}+\left(S_{\min } / S_{0}\right)^{N_{p}-2}
\end{aligned}
$$

where $N$ is the crack propagation constant appropriate for the proof test environment, $F$ is the failure probability after proof testing, $F$ is the lailure probability of the proof test and $S_{\min }$ is the finimum inert strength of a sample that just passes the proof test cycle, i.e. the truncation strength. It is significant to note that the inert strength after proof testing is truncated at $S_{\text {in }}$ and will be greater than the initial inert strength at all levels of failure probability if $m<\mathrm{N}_{\mathrm{p}}-2$ (4).

For a given material and proof test environment, $S_{\text {min }}$ is determined only by the unloading rate $\left(\sigma_{u}\right)$ from the prootin stress (4):

$$
S_{\min }=\left[\dot{\sigma}_{u} B_{p}\left(N_{p}-2\right)\right]^{1 / 3}\left[3 /\left(N_{p}+1\right)\right]^{1 /\left(N_{p}-3\right)}
$$

where $\mathrm{B}_{\text {is }}$ is the crack propagation constant appropriate for the proof test environment. If $\sigma^{\prime}>0$, Equation (6) shows that proof testing always truncates the strength distribution. The higher $\dot{\sigma}_{u}$, the greater is the strength level, S min, at which truncation occurs. However, since $S_{\text {min }}$ cannot be greater than the maximum stress, $\sigma$, during the proof test, $\sigma$ is an upper bound for $S_{\text {min }}$. Substitution of $\sigma$ for $S$ min in Equation (6) gives the minimum unloading rate $\mathrm{fBr}$ whichin is approximately equal to the truncation strength. Equation (6) also shows that good proof test conditions (high $\mathrm{N}_{\mathrm{P}}$ ) result in a high $\mathrm{S}_{\min }$.

The failure probability of the proof test $\left(F_{p}\right)$ can be determined directly from the number of specimens that break during the proof test or can be predicted from (4):

$$
-\ln \left(1-F_{p}\right)=\left(S_{0}^{m}\right)^{-1}\left(D_{p} / B_{p}\right)^{m /\left(N_{p}-2\right)}
$$


where $D_{p}=\int_{0}^{t} \sigma_{p}^{N} p_{p}(t)$ dt represents the amount of strength

degradation during the proof stress cycle. For a typical proof test, the component is loaded at a constant rate, $\dot{\sigma}_{1}$, held at the maximum proof. stress, $\sigma$, for a time $t$, and then unloaded at a constant rate, $\dot{\sigma}^{\circ}$. In Regrating the $\mathrm{D}_{\mathrm{p}}^{\mathrm{P}}$ ' equation for this typical proof strèss cycle gives:

$D_{P}=\sigma_{p}{ }_{p}^{N} t_{p}+\left[\sigma_{p}{ }_{p}^{N+1} /\left(N_{p}+1\right)\right]\left(1 / \sigma_{u}+1 / \sigma_{1}\right)$

By coupling Equation (5) with Equations (2) and (3), the $t_{E}$ and $\sigma_{f}$ distribution after proof testing can be predicted for any service environment (4). Of particular interest is the minimum lifetime ( $t_{\text {min }}$ ) in service of a component after proof testing. This is oftained by substituting $S_{\text {min }}$ for $S$ in Equation (2) so that:

$$
t_{\min }=B S_{\min }{ }^{-2} \sigma_{a}^{-N}
$$

where now $B$ and $N$ are the appropriate crack parameters for the service environment.

Equations (5) - (9) swmarize failure predictions for ceramic materials after proof testing. These failure predictions are dependent on the crack propagation parameters $B$ and $N$. These parameters must be determined in a test environment that simulates the appropriate proof-test and service conditions and can be obtained from one of three type of experiments: crack velocity experiments, stress rupture experiments, and stressing rate experiments (3). From crack velocity experiments, Equation (1) is used to determine $A$ and $N$; $K_{T C}$ is determined in a separate experiment. Stress rupture data $\left(t_{f}\right.$ vs. $\left.\sigma_{f}\right)$ and the inert strength data are used to determine $B$ and 7 from Equation (2), whereas stressing rate data ( $S$ vs. $\delta$ ) and median inert strength data are used to calculate $B$ and $N$ from Equation (3). The stress rupture and stressing rate techniques are commonly referred to as-static-fatigue and dynamic fatigue, respectively.

\section{APPLICATION}

The fracture mechanics princifles described in the previous section have been experimentally verified for soda-lime glass (3) and alumina (5) in a moist environment. Specifically, these studies showed that the three experimental techniques for measuring the crack propagation parameters $B$ and $\mathrm{N}$ give equivalent results, that the time-to-failure and strength failure probability distributions can be predicted from Equations (2) and (3) coupled with Equation (4), and that strength distributions after proof 
testing can be predicted on the basis of Equation (5). The purpose of this section is to describe three applications of fracture mechanics principles in assuring against the fatigue failure of ceramic components in service.

\section{Failure Statistics}

For alumina substrates fabricated by cofired metallurgy, stress corrosion cracking can be a serious problem. The metals most cormonly cofired with alumina are either molybdenum or tungsten. Because these metals possess lower thermal expansion coefficients than alumina, their cosintering can cause the ceramic to retain residual tensile stresses of considerable magnitude. Subsequent cleaning and plating baths, necessary to render the metallurgy solderable, expose the substrate to conditions that promote stress corrosion cracking in the alumina. To statistically assess the susceptibility of polycrystalline

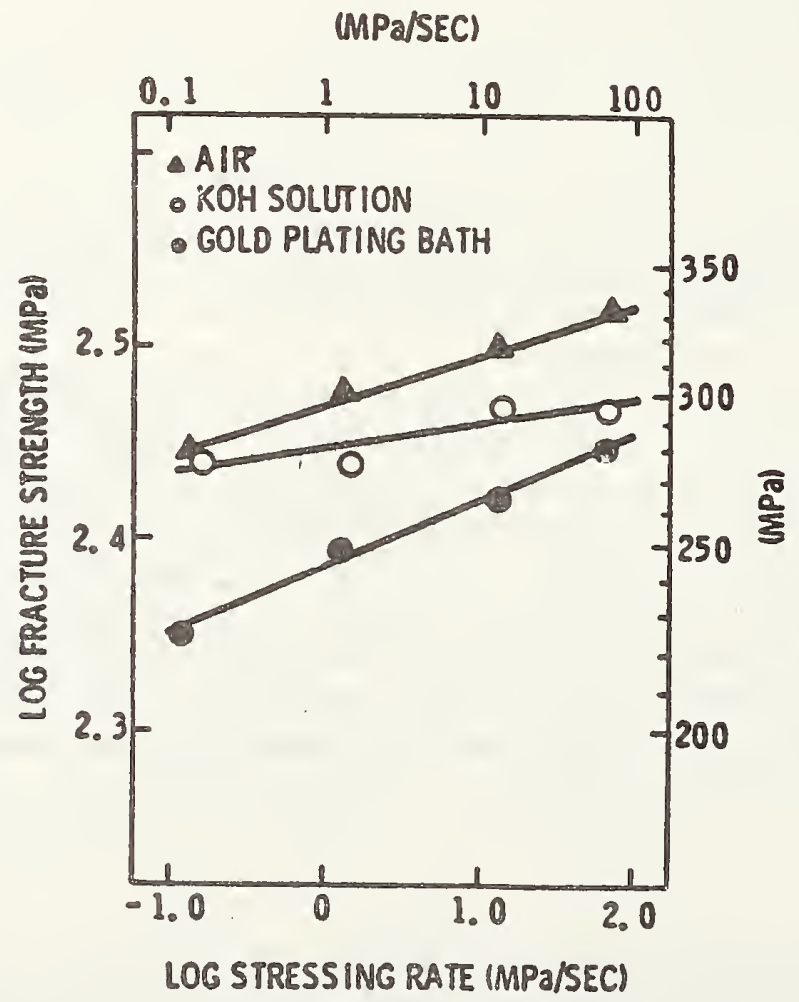

Figure 1. Dynamic fatigue data of polycrystalline alumina in a $\mathrm{KOH}$ cleaning solution at $100^{\circ} \mathrm{C}$, in a gold-plating bath at $78^{\circ} \mathrm{C}$, and in moist air at $30^{\circ} \mathrm{C}$ and $80 \% \mathrm{RH}$ (from Ref. 6). 
alumina to stress corrosion cracking under processing conditions, the stressing rate technique was used to characterize the crack propagation parameters for alumina in a $\mathrm{KOH}$ cleaning solution at $100^{\circ} \mathrm{C}$ and a gold plating solution at $78^{\circ} \mathrm{C}(6)$.

Figure 1 gives the experimental results of strength as a function of stressing rate of alumina in the $\mathrm{KOH}$ and gold solutions (6). For comparison, the fatigue strength results determined for the same alumina in a moist air environment are included (5). From this data and a knowledge of the inert strength of the samples, the crack propagation parameters $B$ and $\mathrm{N}$ were determined from Equation (3) for the various environments.

To validate the applicability of fracture mechanics principles in predicting failure probability in the processing solutions, the actual fatigue strength distributions were compared to predictions based on Equation (3) using the appropriate values for $B$ and $N$ and the inert strength distribution of the samples. Figure 2 gives these comparisons and it is evident that agreement between the theoretical predictions and the actual fatigue strength distributions
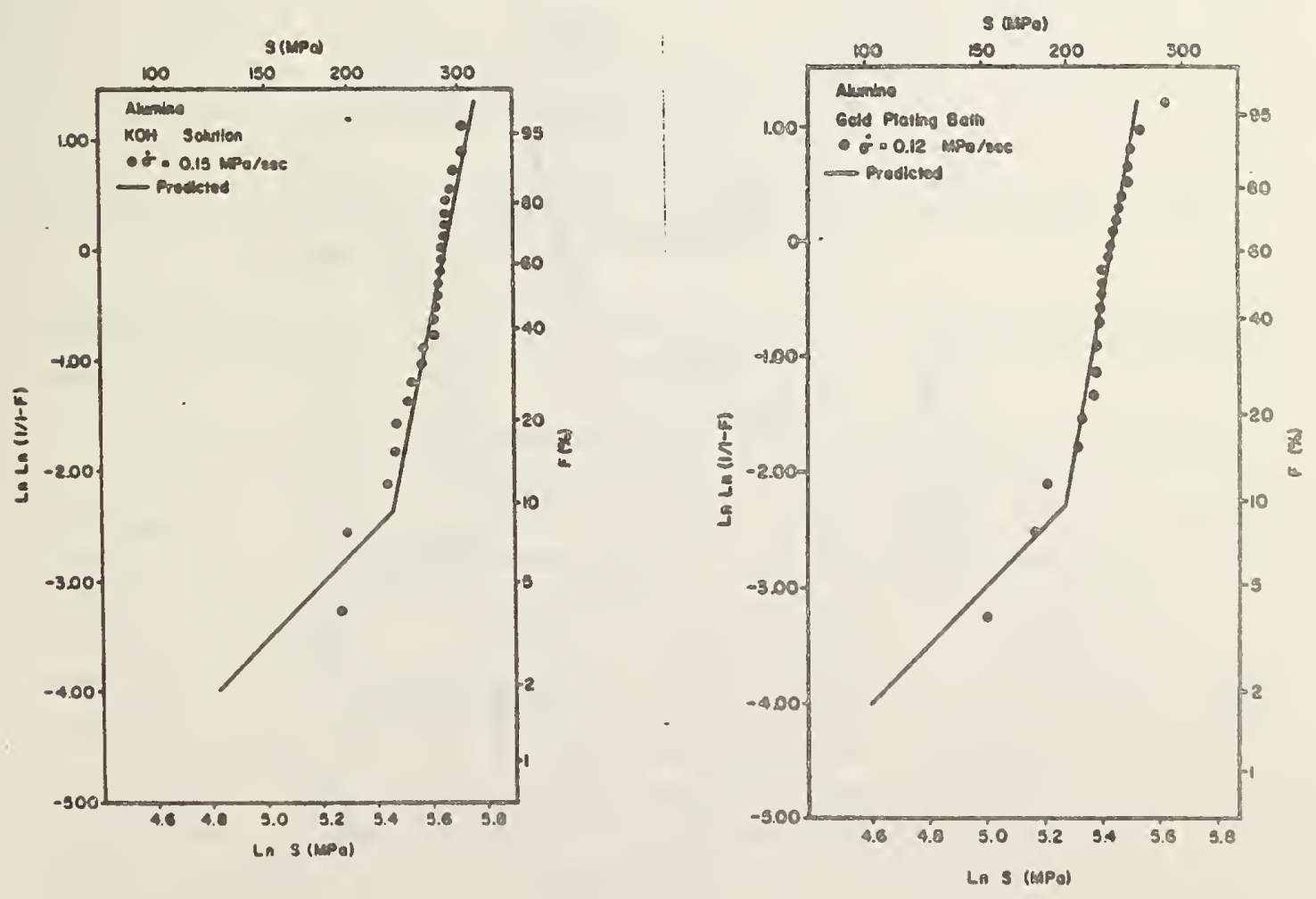

Figure 2. Comparison to theoretical predictions of the strength distributions of polycrystalline alumina in a) $\mathrm{KOH}$ cleaning solution at $100^{\circ} \mathrm{C}$ and b) gold plating bath at $78^{\circ} \mathrm{C}$ (from ref. 6). 
is good. It should also be noted that these strength distributions are bimodal since the low strength regime of the distribution was caused by gross flaws induced in the samples during grinding.

The severity of the processing conditions on the alumina substrates can be most easily assessed by means of a lifetime prediction diagram (Figure 3) based on Equation (2) and the inert strength distribution of the substrates. Although the strengths of the substrates could not be measured directly, they were estimated from the strength distribution of the samples and the Weibull size relation:

$$
s_{1}=s_{2}\left(A_{2} / A_{1}\right)^{1 / m}
$$

where $S_{1}$ and $S_{2}$ are the strengths of the substrates and samples, respectively, and $A_{1}$ and $A_{2}$ are the surface area of the substrates and samples, respectively. Figure 4 shows the estimated inert strength distribution of the substrates. It should be noted that it was assumed that the inert strength distribution of the

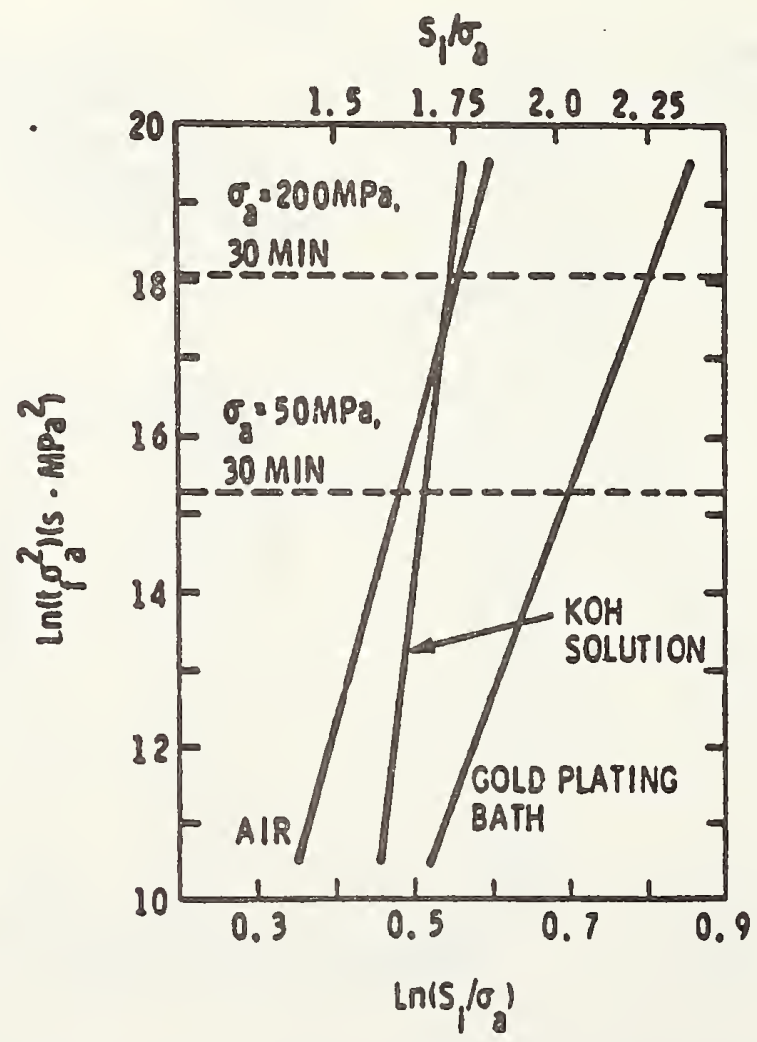

Figure 3. Lifetime prediction diagram for polycrystalline alumina in wet processing environments and moist air (from ref. $6)$. 


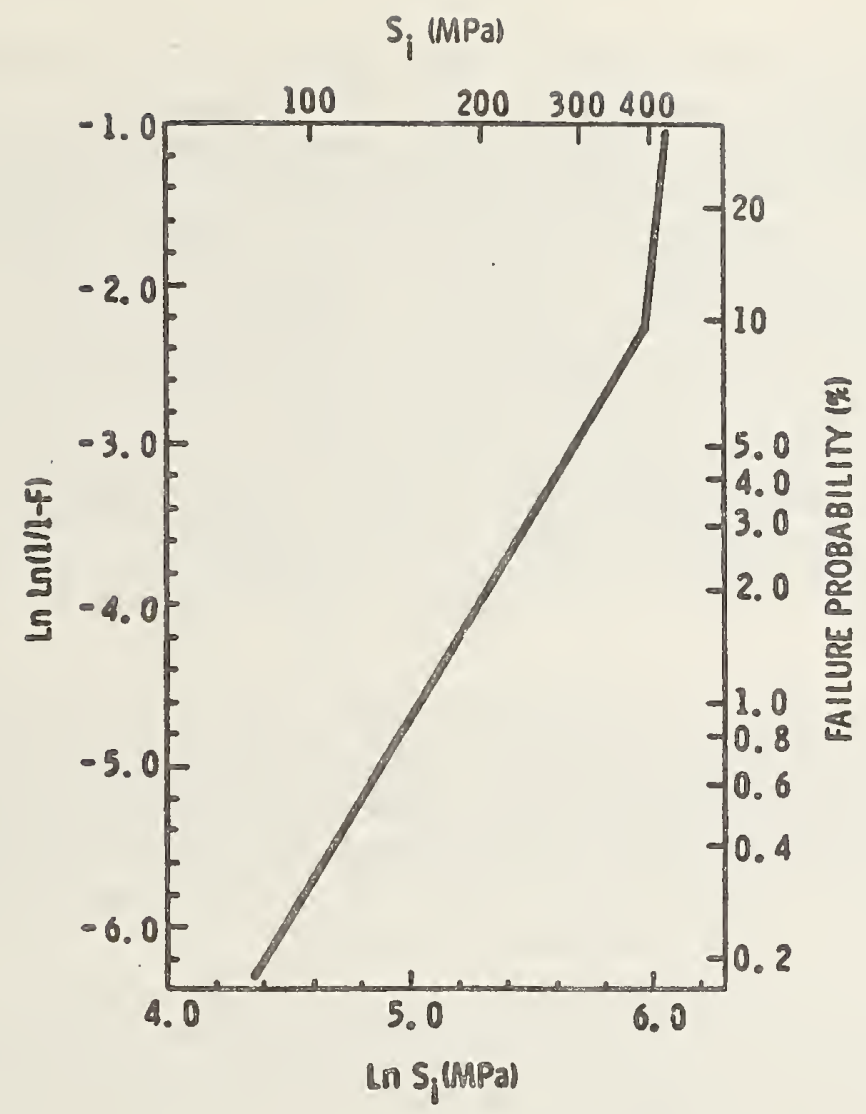

Figure 4. Estimated Weibull inert strength distribution for alumina substrates (from ref. 6).

substrates was not altered through any interaction between the metal and alumina during sintering.

The residual tensile stress in a substrate having cofired metallurgy is dependent on the thermal expansion mismatch between the metallurgy and the ceramic, the temperature difference between the set point of the system and room temperature, and the geometry of the metallurgy in the system. In molybdenum-alumina substrates residual stresses of $200 \mathrm{MPa}$ can be generated. If substrates having such stresses are subjected to the $\mathrm{KOH}$ cleaning solution or the gold-plating solution for 30 minutes, respective $\mathrm{S} / \sigma$ ratios of 1.75 and 2.27 are predicted (Figure 3 ). Since $\sigma$, is kñown, $S$ can be calculated and a failure probability determined from Figure 4. With a $200 \mathrm{MPa}$ residual stress, an $8 \%$ failure rate would be expected for the substrates in the $10 \% \mathrm{KOH}$ solution, and $40 \%$ of the substrates in the gold-plating bath would crack after 30 minutes: Also, substrates having a residual stress of this magnitude would have a failure rate of $8 \%$ in hot, humid air. clearly, failure rates of this magnitude are unacceptable. 
The failure probability of the substrates can be lowered by: (1) using a stronger alumina to make the substrates, (2) reducing the processing times, or (3) reducing the residual stress in the substrates. The obvious choice is to reduce the residual stress in the ceramic. This can be accomplished by reducing the thermal expansion mismatch between the metal and the ceramic, by altering the geometry of the system, or by a combination of both. Since the thermal expansion differential can be reduced only by altering the metal configuration and/or the ceramic, this choice alone is not particularly attractive. Similarly, if the stress is lowered only through geometric redesign, the potential geometric density of the metallurgy in the system becomes limited. Thus, a combination of both approaches is generally considered most effective in reducing stress.

Obviously, the ideal solution would be to completely eliminate any residual tensile stress in the substrates; this, however, is not always possible without drastically altering the material system. The problem then is to reduce the failure probability of the substrates to a magnitude compatible with good product reliability.

Regardless of the technique used, if the stress in the ceramic is lowered, for instance, to $50 \mathrm{MPa}$, the lifetime prediction diagram and the inert strength distribution can again be used to assess the probability of stress corrosion cracking of the substrates. If substrates having a residual stress of $50 \mathrm{MPa}$ are placed in the $\mathrm{KOH}$ cleaning solution or in the gold plating bath for 30 minutes, it can be determined from Figure 3 and 4 that the failure probabilities are 0.2 and $0: 34 \%$ respectively. While the possibility of stress corrosion cracking of substrates during processing is not completely eliminated by reducing the residual stress to $50 \mathrm{MPa}$, the resultant failure rates are now low enough so as to offer a minimal impact on product reliability.

The above examples of lifetime predictions serve to illustrate the importance of fracture mechanics theory in designing electronic substrates fabricated by cofired metallurgy, namely, that substrates of various designs can be compared for the probability of stress corrosion cracking due to the residual tensile stress in the substrates. In this way, fracture mechanics theory is useful in making more rational design decisions. These predictions can also be checked by fabricating substrates of several designs with different residual stresses, and then subjecting the substrates, for instance, to the gold-plating bath for a given period of time. By comparing the incidence of stress corrosion cracking with that predicted by fracture mechanics theory, the theory can be experimentally validated. This was done in the present research program, and the experimental results generally agreed with those theoretically predicted $(6)$. 
Proof Tẹting

Over speed proof testing is used in the grinding wheel industry to assure individual wheel safety by providing protection against excessive variability in wheel strength and fatigue failure. Empirical standards have been established for overspeeding on the basis of measurements of relative strengths and experience from wheel usage. To place overspeed proof testing on a more sound, fundamental basis, the fracture mechanics principles described in the previous section were applied to verifying the use of overspeed proof testing in assuring against the fatigue failure of vitrified grinding wheels (7). Two vitrified wheel specifications were used in this study: 17A90-I5-VX2 and 2A601-K4-V9676. For purposes of identification these two specifications will be labelled VGW1 and VGW2, respectively.

To measure the crack growth parameters appropriate for VGWI and VGW2 in a commercial coolant, stress rupture and stressing rate experiments were used (7). Figure 5 compares minimum lifetime predictions for these two vitrified grinding wheels based on the two test techniques (in this case labelled static fatigue and dynamic fatigue). This figure is based on Equation (9) where $S$ is taken to be equal to $\sigma$. Since the maximum applied stress in service for these two vitpified grinding wheels was calculated to be 1280 psi and the desired minimun lifetime in service was 6 weeks (7), it is evident from Figure 5 for a given vitrified grinding wheel composition the $\sigma / \sigma$ ratio based on the two test techniques are not significantly differrent. From the $\sigma_{\mathrm{p}} / \sigma_{\mathrm{a}}$ ratio the overspeed proof test could then be calculated.

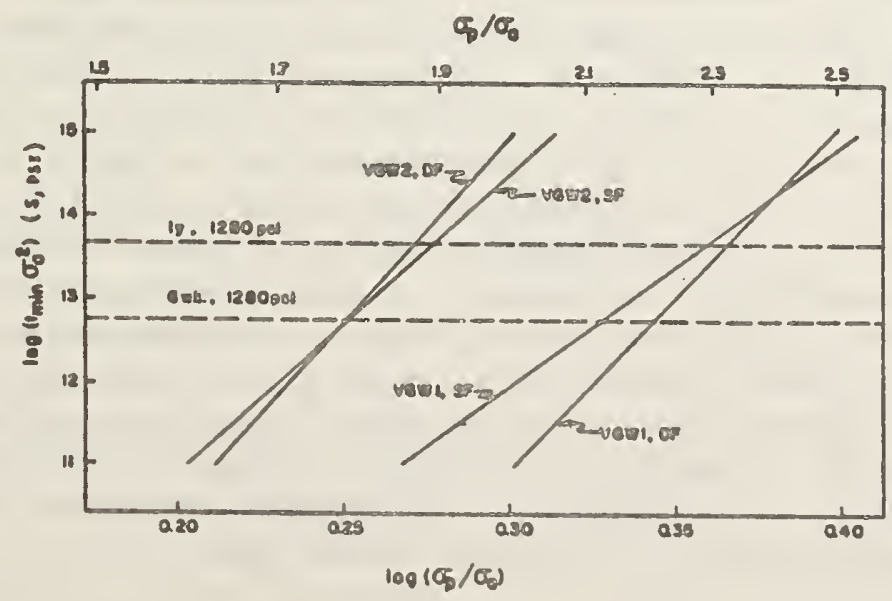

Figure 5. Minimum lifetime predictions comparing static fatigue (SF) and dynamic fatigue (DF) techniques for VGWI and VGW2 in aqueous coulant at $35^{\circ} \mathrm{C}$ (from reference 7 ). 
Table 1

Prediction of the Spin-Proof-Ratio (SPR) Necessary to Insure Against Delayed Failure in Service of Vitrified Grinding Wheel for a 6 Week Lifetime at 1280 psi. (after Reference 7)

\begin{tabular}{cccc} 
Materia1 & Test Technique & $\sigma_{\mathrm{p}}$ (psi) & SPR \\
\hline VGW1 & Static Fatigue & 2715 & 1.57 \\
VGW1 & Dynamic Fatigue & 2825 & 1.60 \\
VGW2 & Static Fatigue & 2285 & 1.45 \\
VGW2 & Dynamic Fatigue & 2280 & 1.45
\end{tabular}

Table I summarized these results where the spin-proof-ratio (SPR) is defined to be the overspeed proof divided by operating speed. These predicted SPR for the vitrified grinding wheels evaluated in this study can be compared to those actually used: 1.80 for VGW1 and 1.50 for VGW2. It is evident from these results that the SPR actually used for these wheel specifications is greater than that predicted on the basis of fracture mechanics theory. Therefore, it is believed that the overspeed proof test currently used for these vitrified grinding wheel compositions is adequate for preventing fatigue failure in service. In support of this conclusion it is significant to note that there has never been a known fatigue fallure in service for these wheel specifications.

To further demonstrate the effectiveness of proof testing, the distribution of initial wheel bursting strengths for the wheel specification VGW2 was compared to that after overspeed proof testing ( 7 ). The tested wheels had dimensions $20 \times 1 \times 5$ in. For the proof test the wheels were accelerated in air up to the proof speed of 4550 RPM and then quickly decelerated. During proof testing 3 of the 20 wheels burst. Figure 6 compares the initial wheel bursting strengths to the after-proof strengths. The wheel bursting strength was taken to be the tensile stress present at the wheel arbor when reached its burst speed. It is. quite evident that proof testing eliminated the weak samples, resulting in the after-proof strength distribution being stronger than the initial distribution. It is also important to note the good agreement between theory and experiment.

Characterization of High Temperature Fatigue Behavior

The increasing demand for materials that will perform under temperature conditions too severe for metals has led to many possible applications for ceramics. Thus, it is important to 


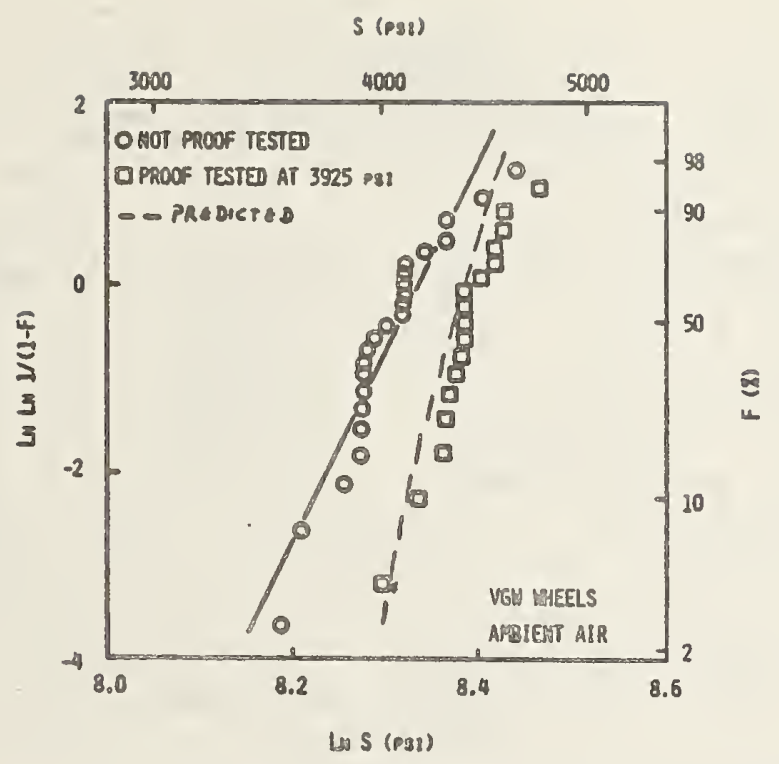

Figure 6. Comparison of wheel bursting strengths before and after proof testing for wheel specification VGW2 (from ref. 7).

characterize the strength and fatigue behavior of ceramics at elevated temperatures to establish allowable stress levels for component design. To study the high temperature strength and fatigue behavior of high purity alumina (Wesgo AI 995) the stressing rate test technique was used because of its simplicity (8).

The effect of temperature on the strength and fatigue behavior of high purity alumina is given in Figure 7 (8). The temperature dependence of both strength and fatigue behavior is small up to $500^{\circ} \mathrm{C}$. From 800 to $1100^{\circ} \mathrm{C}$ both the strength and fatigue resistance decreases markedly. A convenient way to show the effects of fatigue is to compare minimum lifetime predictions, based on Equation (9) taking $\mathrm{S}_{\text {min }}$ to be equal to $\sigma$, as a function of temperature. Figure 8 gives these predictiohs and clearly illustrates that there is little difference in the fatigue behavior of high purity alumina from 23 to $500^{\circ} \mathrm{C}$; however at higher temperatures fatigue effects become very important. For example, to assure a minimum lifetime of one year under a service stress of $100 \mathrm{MPa}$ the required proof stress ratio is 2.27 for a temperature of $23^{\circ} \mathrm{C}$ but for $1000^{\circ} \mathrm{C}$ it is 6.90 and for $1100^{\circ} \mathrm{C}$ it is 14.91 . These elevated temperature proof stress ratios would result in such large proof stresses that no sample would be able to pass the proof test. To get more reasonable proof stresses, the expected minimum life or allowable stress in service must be decreased for these elevated temperatures. For example, if the allowable stress is reduced to $30 \mathrm{MPa}$, then the proof stress to insure a minimum lifetime of 1 year at $1000^{\circ} \mathrm{C}$ is $179 \mathrm{MPa}$ and $361 \mathrm{MPa}$ at $1100^{\circ} \mathrm{C}$. 


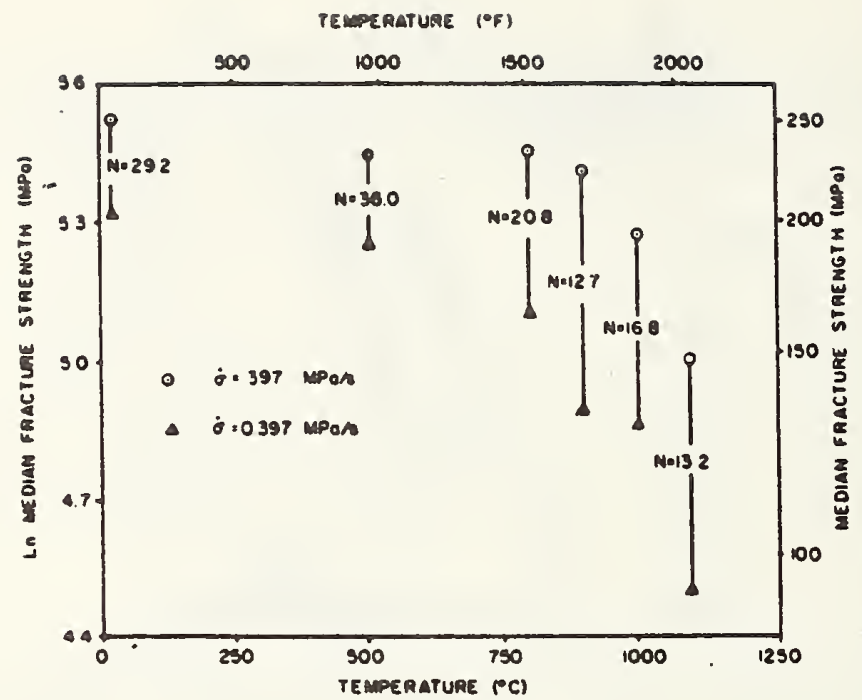

Figure 7. Median fracture strength of alumina as a function of temperature and stressing rate (from ref. 8).

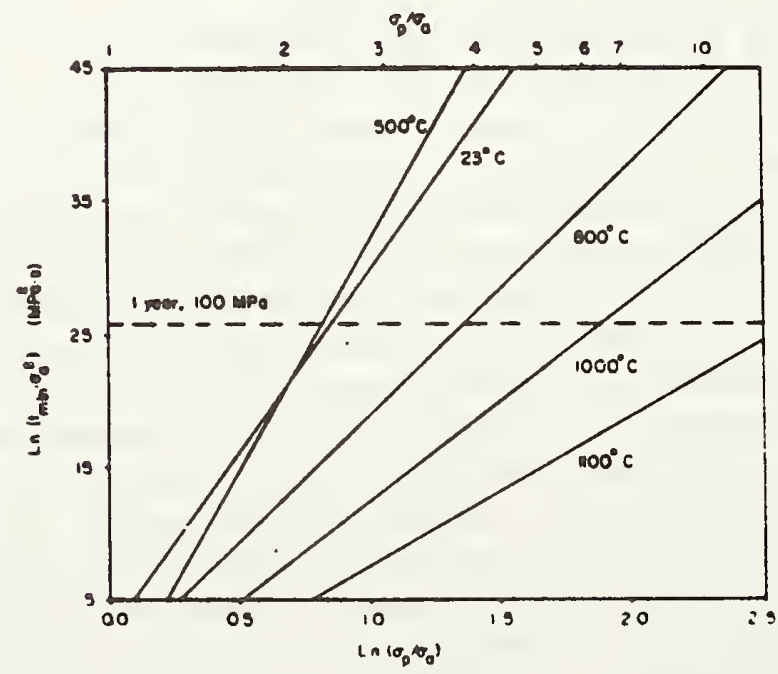

Figure 8. Minimum lifetime prediction diagram for alumina as a function of temperature (from ref. 8). 
Scanning electron micrographs showed that the fracture in this high purity alumina changed from transgranular at $23^{\circ} \mathrm{C}$ to intergranular at temperatures above $800^{\circ} \mathrm{C}(8)$. In addition, a glassy phase was found at the fracture origins of the samples tested at above $800^{\circ} \mathrm{C}$, giving evidence that the glassy phase is playing a major role in determining the strength and fatigue behavior of high purity alumina at elevated temperatures. However, proof test results ( 8 ) showed that the preexisting flaw population is not altered at elevated temperatures. Figure 9 compares the strength distribution of alumina at 23 and $1100^{\circ} \mathrm{C}$ before and after proof testing at room temperature. It is evident that this proof test eliminated the weak samples so that the after proof strength distribution at low failure probabilities are stronger than the initial distributions and that agreement between theory and experiment is good. On the other hand, Figure 10 shows that proof testing alumina at $1000^{\circ} \mathrm{C}$ is not effective in improving the strength distribution at $1000^{\circ} \mathrm{C}$; however, the good agreement between experiment and theory gives evidence that fracture mechanics theory applies. In this case weak samples are eliminated by proof testing at $1000^{\circ} \mathrm{C}$, but flaw growth during the proof test weakens the survivors to such a degree that proof testing is not effective in improving the strength distribution.

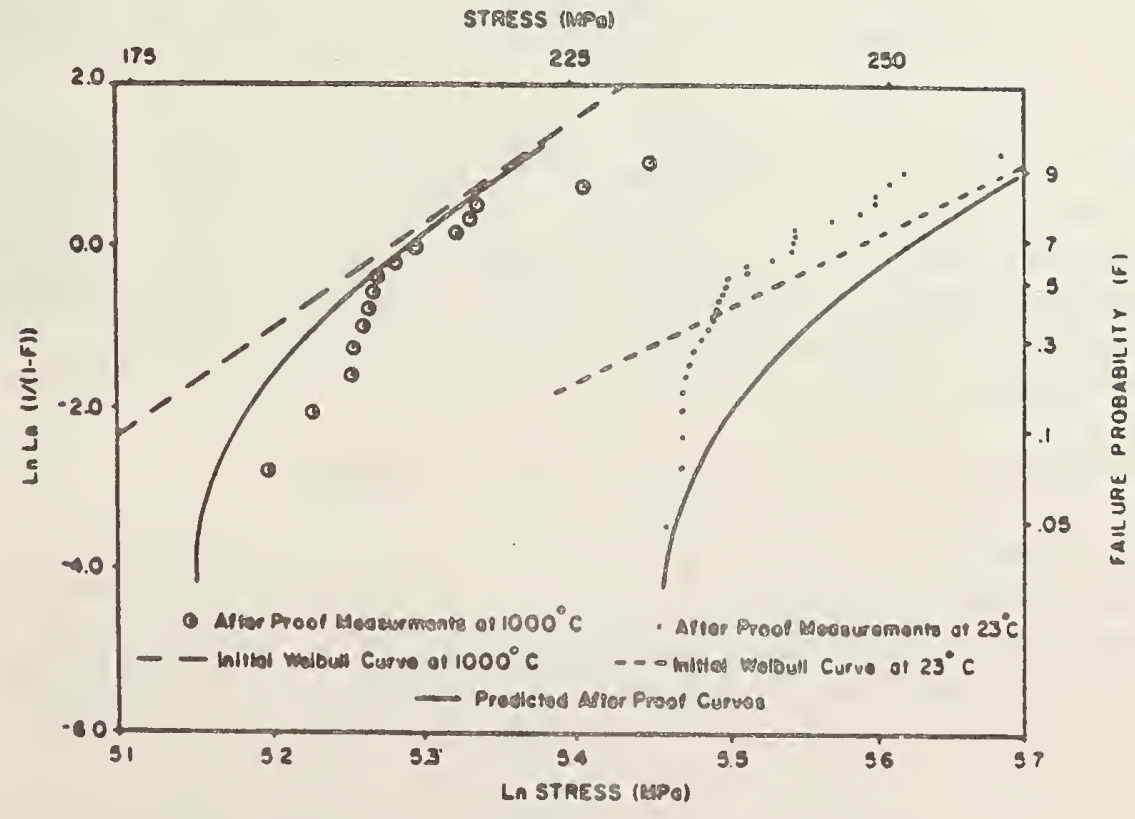

Figure 9. Effect of room temperature proof testing on the strength distribution of alumina at $23^{\circ} \mathrm{C}$ and $1000^{\circ} \mathrm{C}$ (from ref. 8). 


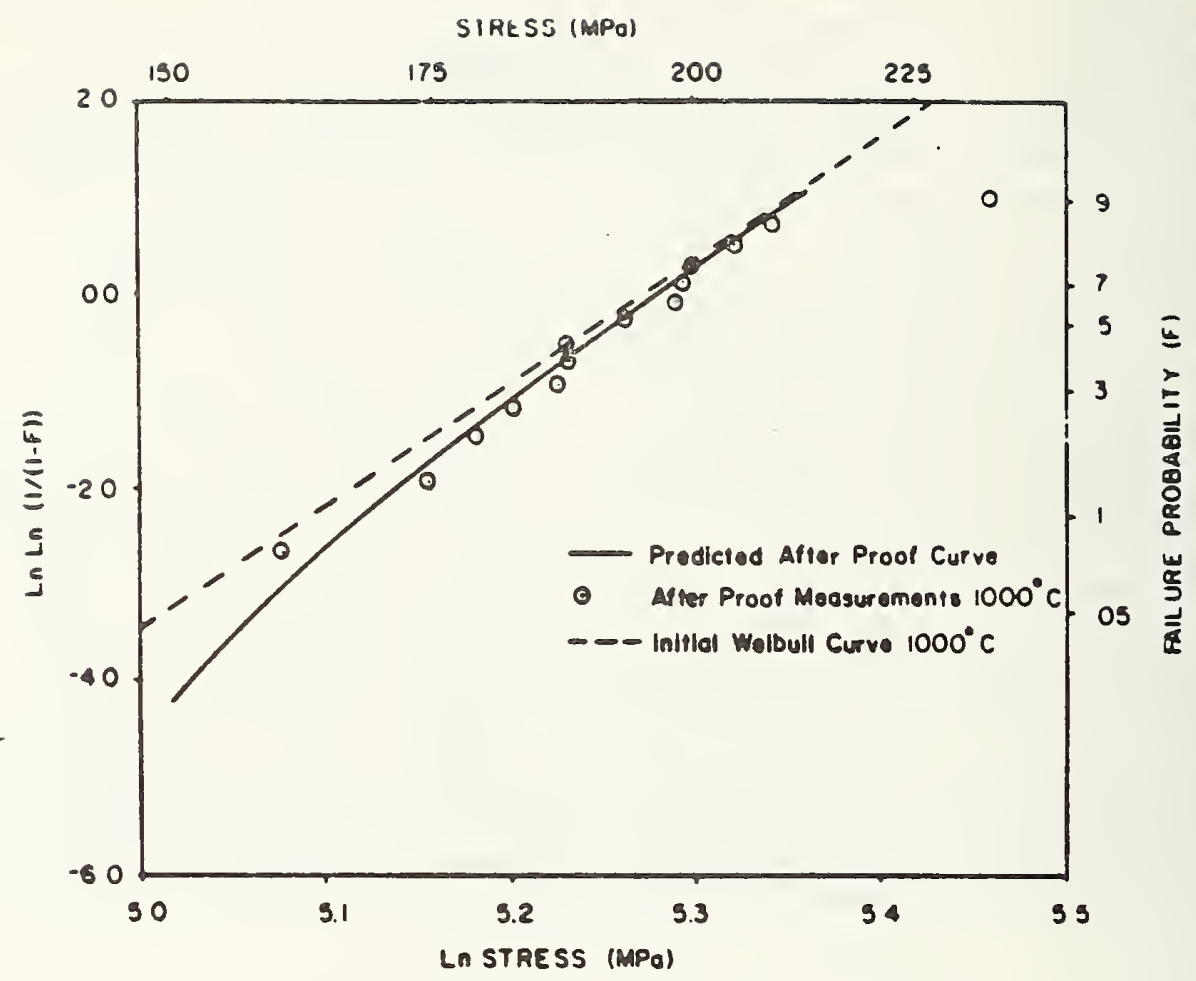

Figure 10. Effect of proof testing at $1000^{\circ} \mathrm{C}$ on the strength distribution of alumina at $1000^{\circ} \mathrm{C}$ (from ref. 8).

In summary, it is believed that at moderate temperatures the fatigue failure of alumina is caused by moisture assisted subcritical crack growth; whereas, at elevated temperatures it is caused by subcritical crack growth enhanced by the presence of a glassy phase. It is also thought that the same pre-existing flaws control the strength both at room temperature and at elevated temperatures.

\section{LIMITATIONS OF THE LIFETIME PREDICTION METHOD}

The lifetime prediction theory presented in this paper is based on the assumption that subcritical crack growth from preexisting flaws is the only mechanism of strength degradation. Using this assumption, component lifetime can be predicted once the initial flaw population, the crack growth rate and the critical crack size have been determined. The theory is deterministic because the element of chance is eliminated from the lifetime prediction once these parameters have been evaluated. The accuracy of the lifetime prediction will depend on both the accuracy with which the pertinent parameters can be evaluated $(9-11)$, and the adequacy of the crack growth equation (12). This requirement does not detract from the basic deterministic nature of the method. The prediction scheme can, however, be 
invalidated when the basic assumptions of the theory are not satisfied. Thus, fracture processes, other than subcritical crack growth, can invalidate failure predictions based on this theory. Unfortunately, other fracture processes do occur for materials currently under consideration for use in heat engines, so that alternate mechanisms of failure must be considered for any scheme of predictive failure for heat engine components. As will be shown, proper modeling of these factors permits extension of the theory to handle fracture situations that are not currently included in the method of lifetime prediction.

As with most other ceramic materials, silicon nitride and sllicon carbide fail at low temperatures from preexisting flaws. As discussed by Rice et al. $(13,14)$ and by Richerson and Yonushonis (15), these flaws are usuliy surface cracks introduced into silicon nitride and silicon carbide components by machining when the components are manufactured. For hot-pressed silicon nitride at temperatures less than $\sim 1000^{\circ} \mathrm{C}$, fracture originates from surface flaws in a completely brittle manner $(13,14)$. At higher temperatures, however, plasticity of components and effects resulting from the reactive nature of the test environment intervene to alter the mode of fracture (13). The same types of effects occur for hot-pressed silicon carbide at higher temperatures $\left(\sim 1400^{\circ} \mathrm{C}\right)$. In oxidizing environments, the effects of temperature on mechanical behavior can be attributed to: (1) enhanced plasticity at the crack tip which results in subcritical crack growth by creep fracture $(16,17)$, and (2) surface oxidation which results in the healing of surface machining cracks, and for some materials, the generation of new flaws that act as new origins for fracture $(13-15,18-20)$. Both processes have to be considered to accurately predict the lifetime of high temperature structural components. A variety of other processes (thermal shock, particle impact, chemical corrosion, component contacts, etc.) can also intervene to effect the fracture behavior of heat engine ceramics. Although a complete theory of failure would require all of these processes to be considered, such extensive considerations are clearly beyond the scope of this paper. The discussion in the remainder of this paper will be more limited in scope, dealing with pit formation, crack healing and crack growth. Materials to be considered are magnesia-doped, hot-pressed, silicon nitride and reaction bonded silicon nitride for which the processes that occur at elevated temperatures are best understood.

High temperature oxidation has been shown to be particularly effective in altering the initial flaw population in hot-pressed, silicon nitride (NC132). Investigations of the strength and oxidation behavior of this material have shown that surface induced machining flaws are reduced in severity by high temperature oxidation of the ceramic surface $(13-15,18-20)$. The 
oxidation process is complex involving mass transport of impurities from the matrix, and transport of oxygen and nitrogen through the glass oxide layer that forms on the surface of the ceramic $(17,21)$. As the oxide scale grows, the initial silicon nitride surface recedes, reducing the size of the surface cracks and thus their severity (Figure 11). If oxidation continues long enough, the surface cracks can be completely removed from the ceramic surface. In addition to crack removal by dissolution, plastic deformation at elevated temperatures also permits blunting of machining flaws and relief of surface stresses, thus enhancing the strength of the component $(22,23)$. The effectiveness of oxidation in reducing flaw severity can be illustrated by the introduction of fresh cracks into the surface of silicon nitride by indentation $(20,24)$. As illustrated in Table 2 on hotpressed silicon nitride (billet $B$ ), exposure at $1200^{\circ} \mathrm{C}$ in air increased the strength from $408 \mathrm{MPa}$ at room temperature to 488 $\mathrm{MPa}$ after 100 hours exposure, largely as a result of decreasing the severity of the flaw associated with the indentation. Because of the beneficial effect of oxidation, high temperature exposure in air is being used as a means of improving the finish of hot-pressed silicon nitride ceramic blades $(15,23)$. Similar strengthening results are observed for reaction bonded silicon nitride (NC350) $(23,24)$.

\section{EFFECT OF OXIDATION ON FLAWS IN $\mathrm{Si}_{3} \mathrm{~N}_{4}$}

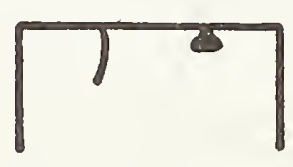

(a)

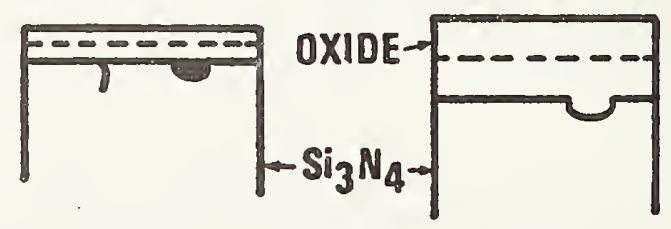

(b)

(c)

Figure 11. Effect of exposure at $1200^{\circ} \mathrm{C}$ on flaws in silicon nitride: (a) surface crack and subsurface inclusion before exposure; (b) after exposure crack size is reduced by surface dissolution and subsurface flaw reacts with environment. At the same time, crack blunting or crack healing occurs; (c) oxide growth has removed the subsurface crack and enlarged the subsurface flaw to produce a pit in the silicon nitride (from ref. 34 ). 
Table 2 .

Strength of Indented Specimens: $2 \mathrm{~kg}$ Load (34)

\begin{tabular}{|c|c|c|c|c|}
\hline Material & $\begin{array}{c}\text { Test-Temp. } \\
{ }^{\circ} \mathrm{C}\end{array}$ & $\begin{array}{c}\text { Exposure } \\
\text { Conditions } \\
\end{array}$ & $\begin{array}{c}\text { Strength } \\
\mathrm{MPa}\end{array}$ & $\begin{array}{c}\text { Fracture } \\
\text { at indentation }\end{array}$ \\
\hline $\begin{array}{l}\text { NC132 } \\
\text { Billet A }\end{array}$ & $\begin{array}{r}25 \\
25 \\
25 \\
1200 \\
1200 \\
1200\end{array}$ & $\begin{array}{r}\text { as indented } \\
16 \mathrm{hr} 1200^{\circ} \mathrm{C} \\
100 \mathrm{hr} 1200^{\circ} \mathrm{C} \\
1 / 2 \mathrm{hr} 1200^{\circ} \mathrm{C} \\
16 \mathrm{hr} 1200^{\circ} \mathrm{C} \\
100 \mathrm{hr} 1200^{\circ} \mathrm{C}\end{array}$ & $\begin{array}{l}397 \pm 12 \\
432 \pm 27 \\
461 \pm 42 \\
438 \pm 15 \\
396 \pm 42 \\
402 \pm 12\end{array}$ & $\begin{array}{l}\text { Yes } \\
\text { Yes } \\
\text { No } \\
\text { Yes } \\
\text { Yes } \\
\text { No }\end{array}$ \\
\hline $\begin{array}{l}\text { NC132 } \\
\text { Billet B }\end{array}$ & $\begin{array}{r}25 \\
25 \\
1200 \\
1200\end{array}$ & $\begin{array}{l}\text { as indented } \\
100 \mathrm{hr} 1200^{\circ} \mathrm{C} \\
1 / 2 \text { hr } 1200^{\circ} \mathrm{C} \\
100 \text { hr } 1200^{\circ} \mathrm{C}\end{array}$ & $\begin{array}{l}408 \pm 17 \\
524 \pm 47 \\
441 \pm 10 \\
488 \pm 11\end{array}$ & $\begin{array}{l}\text { Yes } \\
\text { Yes } \\
\text { Yes } \\
\text { Yes }\end{array}$ \\
\hline NC350 & $\begin{array}{r}25 \\
25 \\
25 \\
1200\end{array}$ & $\begin{array}{l}2 s \text { indented } \\
33 \mathrm{hr} 1200^{\circ} \mathrm{C} \\
100 \mathrm{hr} 1200^{\circ} \mathrm{C} \\
100 \mathrm{hr} 1200^{\circ} \mathrm{C}\end{array}$ & $\begin{array}{l}115 \pm 24 \\
181 \pm 22 \\
225 \pm 38 \\
188 \pm 64\end{array}$ & $\begin{array}{l}\text { Yes } \\
\text { Yes } \\
\text { Yes } \\
\text { Yes }\end{array}$ \\
\hline $\begin{array}{l}\mathrm{NCX}-34 \\
\mathrm{Y}_{2} \mathrm{O}_{3}\end{array}$ & $\begin{array}{r}25 \\
25 \\
1200\end{array}$ & $\begin{array}{l}\text { as Indented } \\
100 \text { hr } 1200^{\circ} \mathrm{C} \\
100 \text { hr } 1200^{\circ} \mathrm{C}\end{array}$ & $\begin{array}{l}491 \pm 16 \\
616 \pm 51 \\
744 \pm 25\end{array}$ & $\begin{array}{l}\text { Yes } \\
\text { No } \\
\text { Yes }\end{array}$ \\
\hline
\end{tabular}

If flaw removal were the only process occurring during oxidation then the lifetime prediction methods presented earlier in this paper could be used as a conservative basis for component design. In this case, the starting flaws would decrease in size as oxidation occurred, and the component would become stronger, not weaker. Research on hot-pressed silicon nitride (NC132) has shown that flaw generation during long term (>100 hr.) exposure results in a decrease in the strength of this material (15, 20, 22). The strength decrease results from pit formation at the ceramic surface due to rapid localized oxidation. Although the exact cause of localized oxidation is not fully understood it probably results from the presence of impurities in the ceramic which increase the oxidation rate as the oxide interface approaches the location of the impurity (Figure 11; 20,26). The formation of glass-like oxide mounds over the pits with holes in the center of the mounds suggests that rapid gas generation is associated with the nucleation and growth of these pits (20). 


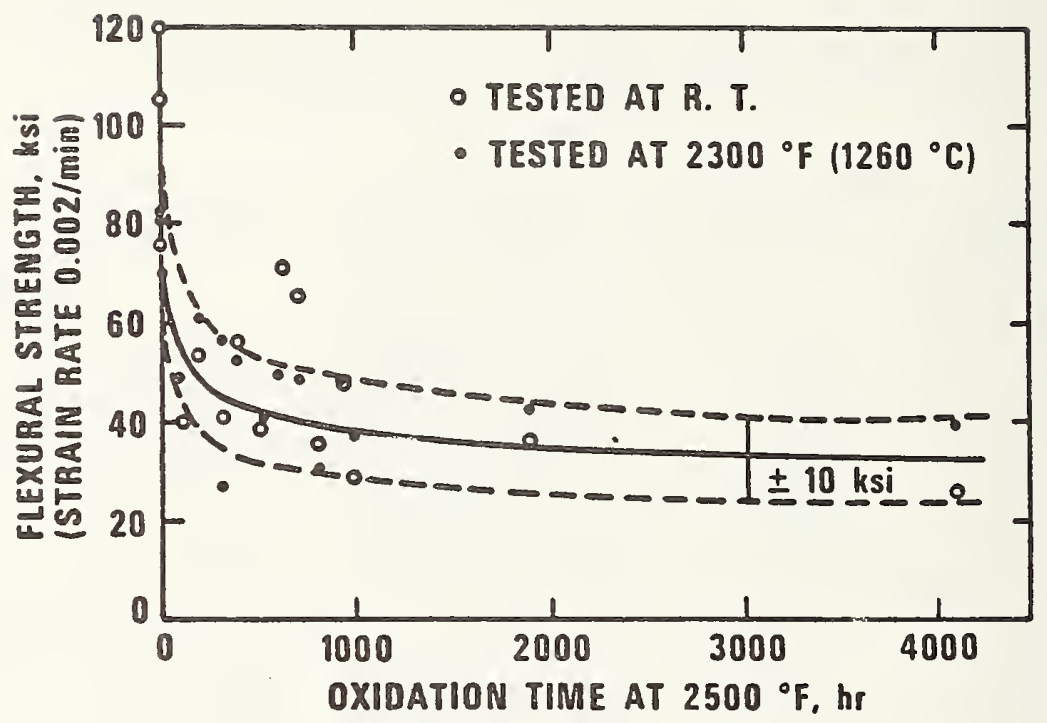

Figure 12. Effect of oxidation at $1371^{\circ} \mathrm{C}\left(2500^{\circ} \mathrm{F}\right)$ on the strength of silicon nitride (NC132). Note that at time zero the scatter in strength is considerably greater than that occurring after substantial periods of exposure (from ref. 25).

The effect of pit formation on the long term strength is illustrated in Figure 12 which shows that after 1000 hours exposure magnesia-doped, hot-pressed silicon nitride has lost approximately 50 percent of its strength (25). This strength decrease seems to occur most rapidly during the initial stages of exposure, suggesting rapid formation of pits initially, and then stabilization of the pit structure after periods of about 1000 hours. Whether or not the pit structure has reached a state of static equilibrium, or is in a state of dynamic equilibrium has not yet been determined.

In freshly machined specimens the combined effect of crack healing, and flaw generation should result in a strength enhancement followed by a strength degradation as pits form in the material $(20,24)$. This type of behavior has been confirmed by a number of investigators. Richerson and Yonushonis (15) have shown, for example, that the strength of transverse ground silicon nitride is increased by exposure to temperatures of $982^{\circ} \mathrm{C}$ or $1066^{\circ} \mathrm{C}$ for 50 hours (Table 3). At higher temperatures or for longer periods of time, a strength decrease is observed as pits are formed in the surface. Wiederhorn and Tighe $(20,24)$ showed that this type of behavior depended on the particular billet used for study, since some biliets increased in strength 
Table 3.

Room Temperature Strength of Hot-Pressed, Silicon Nitride (NC132) Transverse Ground Specimens Tested in 4-Point Bending (15)

\begin{tabular}{|c|c|c|c|}
\hline $\begin{array}{l}\text { Exposure } \\
{ }^{\circ} \mathrm{C}\left({ }^{\circ} \mathrm{F}\right) \\
\text { time }\end{array}$ & $\begin{array}{c}\text { Strength and } \\
\text { Standard Deviation } \\
\text { MPa (KSI) }\end{array}$ & $\begin{array}{l}\text { Samples } \\
\text { Tested }\end{array}$ & $\begin{array}{l}\text { Predominant Fracture } \\
\text { Region }\end{array}$ \\
\hline Control & $\begin{array}{l}450 \pm 36 \\
(63.0 \pm 5.0)\end{array}$ & 12 & Grinding Groves \\
\hline $\begin{array}{l}982(1800) \\
50 \text { hours }\end{array}$ & $\begin{array}{l}657 \pm 61 \\
(92.0 \pm 8.6)\end{array}$ & 50 & $\begin{array}{l}\text { Surface (Flaws not } \\
\text { obvious) }\end{array}$ \\
\hline $\begin{array}{l}1066 \text { ( }(1950) \\
50 \text { hours }\end{array}$ & $\begin{array}{c}636 \pm 41 \\
(89 \pm 5.7)\end{array}$ & 11 & $\begin{array}{l}\text { Surface (Flaws not } \\
\text { obvious) }\end{array}$ \\
\hline $\begin{array}{l}1129(2065) \\
140 \text { hours }\end{array}$ & $\begin{array}{l}593 \pm 36 \\
(83 \pm 5.0)\end{array}$ & 6 & Surface Pits \\
\hline $\begin{array}{l}1129 \text { (2065) } \\
240 \text { hours }\end{array}$ & $\begin{array}{l}443 \pm 58 \\
(62.0 \pm 8.1)\end{array}$ & 6 & Surface Pits \\
\hline $\begin{array}{l}1204(2200) \\
24 \text { hours }\end{array}$ & $\begin{array}{l}529 \pm 19 \\
(74.0 \pm 2.6)\end{array}$ & 12 & Surface Pits \\
\hline $\begin{array}{l}1371(2500) \\
24 \text { hours }\end{array}$ & $\begin{array}{l}457 \pm 29 \\
(64 \pm 4.1)\end{array}$ & 12 & Surface Pits \\
\hline
\end{tabular}

with exposure at $1200^{\circ} \mathrm{C}$ (For times of $100 \mathrm{hr}$ ) while others decreased for the same exposure conditions. Richerson and Yonushonis (15) have made similar observations on hot-pressed, silicon nitride. More recently, the combined effect of flaw healing and pit formation was demonstrated by Jones and Rowcliff (22), for silicon nitride exposed at temperatures of $1370^{\circ} \mathrm{C}$ for periods up to 64 hours. For both indented (knoop; $1 \mathrm{Kg}$ ) and transverse ground specimens, the strength first increased then decreased as the exposure time increased (Figure 13).

Reaction bonded silicon nitride behaves in a manner quite different from that of the hot-pressed material. Flaw healing results in a significant strength increase in this material at elevated temperatures. When the material is cooled to room temperature, however, much of this increase is lost as a result of surface cracking caused by a phase transformation of cristobalite in the oxide coat that forms on the surface at higi temperatures (27). The absence of strength degradation (at $1200^{\circ} \mathrm{C}$ ) 


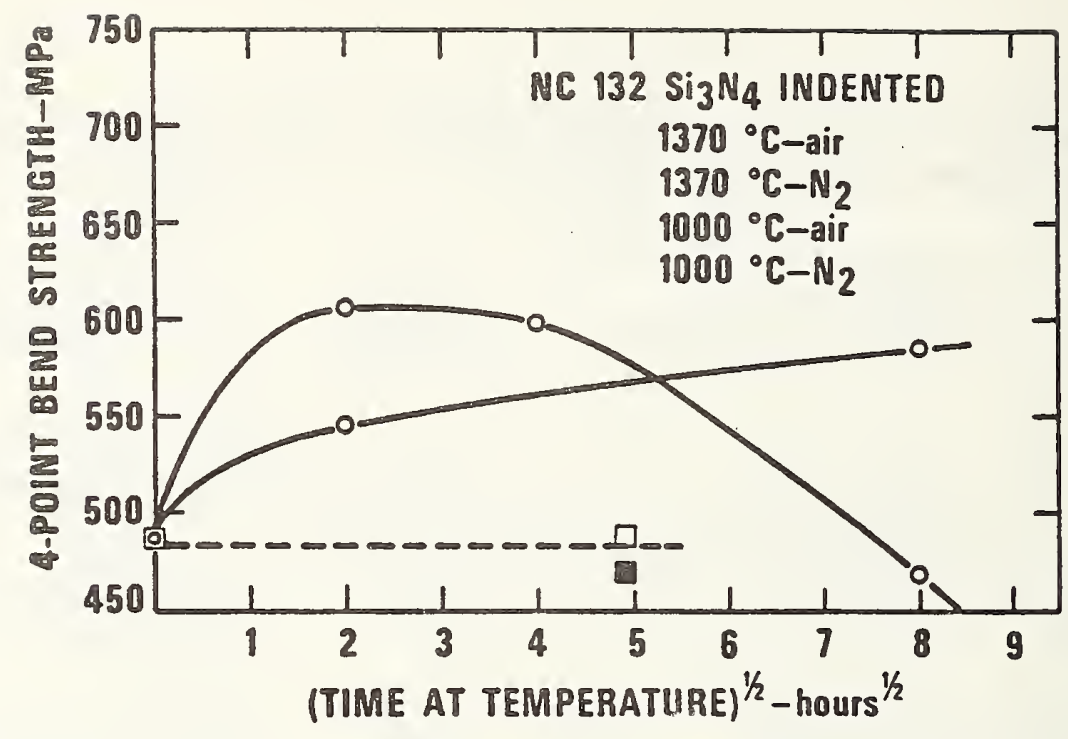

Figure 13. Effect of high temperature exposure on the strength of silicon nitride ( $\mathrm{NC132}$ ) measured at room temperature (from ref. 22).

after sustained (1000 hr.) exposures (28), suggests that pit formation and subcritical crack growth are not significant factors limiting the lifetime of this material.*

\section{LIFETIME ESTIMATE: EFFECT OF FLAW HEALING AND PIT FORMATION}

From the above discussion, we conclude that flaw healing, pit formation and subcritical crack growth must be considered simultaneously in order to establish an accurate method of lifetime prediction. The development of a failure prediction method requires each of these processes to be evaluated independently. Once they have been characterized, mathematical techniques can be used to determine the relative contribution of each of these processes to the total failure time.

Subcritical crack growth can be characterized either by strength or fracture mechanics techniques. However, when flaw healing or pit formation is occurring, the use of strength techniques for evaluating crack growth parameters may not be a good procedure, since both of these processes have an independent effect on the material's strength. The feasibility of quantifying the crack growth rate by fracture mechanics techniques has been demonstrated by Evans and Wiederhorn (30), who have shown that

*Recently, Richerson et al. (29) have observed pit formation in heavily oxidized reaction bonded silicon nitride. 
the crack velocity can be represented as a power function of the applied stress intensity factor (Equation 1). Details on the application of fracture mechanics techniques to crack growth data can be found in ref. 31 .

A second method of collecting crack velocity data was illustrated recently by Rowcliff (22), who used 3 point bend specimens to study the static fatigue of silicon nitride and silicon carbide. The specimens were all indented to form wellcharacterized cracks in the tensile surface of the specimens. The technique is based on the assumption that equation 1 is the correct form of the crack velocity equation. By rearranging Equation 2, the following equation is obtained for the failure time, $t$, of a component that is subjected to a constant applied load

$$
t=\frac{2 a_{i}}{(n-2) v_{i}}
$$

Thus, by measuring the initial crack size, $a_{i}$, and the time to failure, $t$, the initial crack velocity, $v_{i}$, can be determined. The stress intensity factor that corresponds to $v_{i}$ is obtained directly from $a_{i}\left(K_{I_{i}}=\sigma Y \sqrt{a_{i}}\right)$.

Data on flaw healing or on pit formation can be obtained from strength measurements. Data on magnesia-doped, hot-pressed silicon nitride and reaction bonded silicon nitride suggest that crack healing occurs relatively quickly and is completed before pits begin to form in the component surface. Therefore, strength changes during the early stages of component exposure can be used to characterize the crack healing process; strength changes occurring after extended exposure can be used to characterize the pit formation process. For normally machined surfaces, quantification of both of these processes requires the collection of extensive strength data so that the strength distribution can be determined accurately as a function of exposure time.

Data on hot-pressed silicon nitride suggests that both the mean strength and its standard deviation change with exposure time when flaw healing occurs $(20,24,25)$. In terms of a Weibull distribution, Equation 4, both the Weibull strength, $\mathrm{s}_{0}$, and the shape parameter, $m$, are a function of time. Data on reaction bonded silicon nitride suggests that only $S_{0}$ is a function of

*The validity of the data obtained by this technique is limited by the assumption that the crack size at failure is small relative to the specimen dimensions. As has already been noted, this same limitation applies to earlier parts of this paper. 
time (28). The effect of flaw healing on specimens that contain large initial cracks can be determined from studies on specimens that have been indented so that relatively large cracks are introduced into the specimen surface. Studies of this type have been conducted recently by Tighe and Wiederhorn $(20,24)$ and by Cubicciotti et al. (22). The investigation by Singhal et al. (25) of strength degradation after long term exposure suggests that for both crack healing and pit formation $S$ and m seem to approach fixed values after a certain amount of time, so that both distributions eventually become stable with regard to further exposure.

Once crack growth, flaw healing, and pit formation have been quantified, the combined failure probability, and the total time to failure can be estimated. To obtain these estimates it is necessary to develop a procedure to determine which mechanism controls failure at a given probability level. Flaw healing and pit formation as a combined failure mechanism will be discussed first. For simplicity it is assumed that the Weibull slope, $\mathrm{m}_{1}$, for crack healing is less than the Weibull slope, $m_{2}$, for pit formation, and that $\mathrm{m}_{1}$ and $\mathrm{m}_{2}$ do not depend on time. The Weibull strength for crack healing, $S_{1}$, and that for pit formation, $\mathrm{S}_{2}$, are assumed to follow exponential decay curves that can be fit to the following formulae:

$$
\begin{array}{ll}
\text { (flaw healing) } & \mathrm{S}_{1}=\mathrm{S}_{\mathrm{O}_{1}}+\Delta \mathrm{S}_{\mathrm{O}_{1}}(1-\exp (-\alpha t)) \\
\text { (pit formation) } & \mathrm{S}_{2}=\mathrm{S}_{\mathrm{O}_{2}}-\Delta \mathrm{S}_{\mathrm{O}_{2}}(1-\exp (-\beta t))
\end{array}
$$

where $S_{0,} S_{0_{2}}, \Delta S_{0}, \Delta S_{0}, \alpha$ and $\beta$ are determined from experimental strengthldata?" Thel'initial Weibull strengths for flaw healing and pit growth are $S$ and $S$ respectively, while $\Delta S$ and $\Delta S$ are the changes in strength for these two processes after extended ${ }^{\circ}{ }^{\circ}$ exposure times. $\alpha$ and $\beta$ determine the rate at which these changes in strength occur. If Equations 12 and 13 are substituted into Equation 4, time dependent strength distributions are obtained that describe the effect of exposure time on strength.

The type of behavior expected from Equations 12 and 13 is shown schematically in Figure 14. We see that during the initial stages of exposure, failure is determined entirely by the initial flaw population, while in the later stages of exposure, pit formation dominates the strength distribution. At any point in time, the combined failure probability, F, is given by the following relation (32):

$$
(1-F)=\left(1-F_{1}\right)\left(1-E_{2}\right)
$$

where $F_{1}$ and $F_{2}$ are the time dependent failure probabilities for flaw healing and pit formation respectively. Thus, a unique 


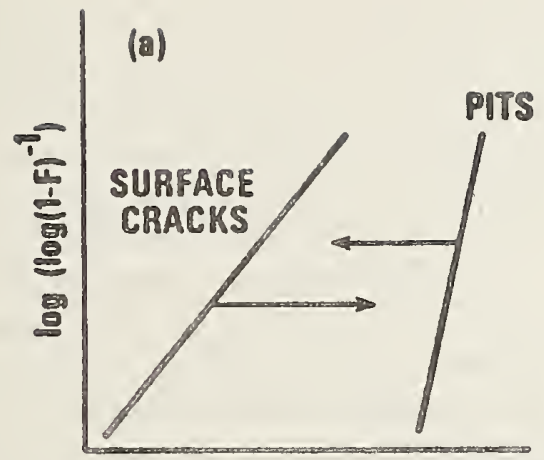

(b)

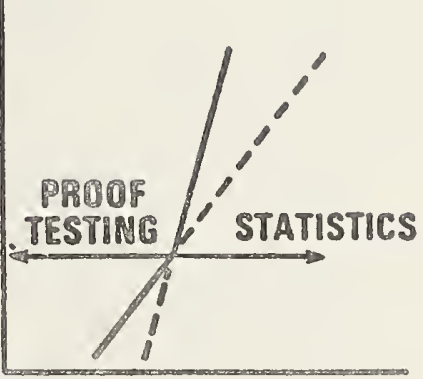

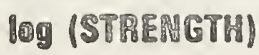

Figure 14. Schematic representation of the effect of high temperature exposure on the strength distribution: (a) initial strength distribution. Curves are assumed to move in the direction of the arrows as the exposure time is increased; (b) distribution after the flaw structure has reached a state of "equilibriur". Proof testing or nondestructive evaluation can be used to improve. reliability at stresses lower than the point of intersection of the two lines, staristics can be used to the right of the point of intersection.

equation is obtained that relates the failure strength, $S$, to the fallure probability, F.

With regard to lifetime prediction, the above discussion is sufficient to draw several important conclusions with regard to proof testing and nondestructive testing. At any time during exposure, the strength of components to the left of the point of intersection of the two curves shown in Figure 14 will be controlled by the initial flaw population. Those specimens that lie to the left of the intersection will contain the largest flaws and consequently will be the ones to be eliminated by proof testing or nondestructive inspection. Since the initial flaw population controls the strength in this regime, proof testing and nondestructive evaluation techniques can be used to truncate the population, and the theory presented earlier in this paper can be used to provide a conservative estimate of the component lifetime. The intersection of the two curves shown in Figure 14 provides an upper limit to the proof test load that can be usefully employed to truncate the initial flaw population. Above this load, component strength depends not on the flaws initially present in 
the component, but on those that are generated by exposure to elevated temperatures $(20,24)$.

After long periods of exposure, proof testing or nondestructive evaluation can be applied again over the entire range of strengths provided the flaw distribution (pits and cracks) has reached a static state. If, however, the distribution to the right of the intersection in Figure 14 represents a dynamic state of equilibrium, then new pits will be continuously generated as the old ones are removed. As a consequence, nondestructive evaluation and proof testing will not be a viable lifetime prediction cechnique. For the dynamic equilibrium situation, statistical techniques such as those described earlier in this paper would have to be used for purposes of lifetime prediction. Pits generated by the oxidation process would serve as the initial flaw distribution for the lifetime prediction.

The combined effects of subcritical crack growth and pit formation on strength can be determined by considering the rate at which each of these processes degrade the strength. As long as strength degradation due to pit formation exceeds that resulting from crack growth, subcritical crack growth will not play a major role in the strength degradation process; when the converse is true, crack growth will dominate the strength degradation process. The switch from one controlling mechanism to the other will occur when the two strength degradation rates are equal.

The rate of strength degradation due to pit formation can be determined by substituting $S_{2}$ of equation 13 for $S_{0}$ of Equation 4, and differentiating with respect to time:

$$
\mathrm{dS} / \mathrm{dt}=-\beta \Delta \mathrm{S}_{\mathrm{O}_{2}}[\exp (-\beta t)] \cdot\left[\ln (1-F)^{-1}\right]^{1 / \mathrm{m}}
$$

The rate of strength degradation due to crack growth has been derived by Fuller et al. (4) and is given by the following expressicin:

$$
d S / d t=-\left(A Y^{2} K_{I C}{ }^{n-2} / 2\right)(\sigma / S)^{n} S^{3}
$$

where $A$ and $n$ are defined by equation $1 ; \mathrm{Y}$ is a geometric constant; $\sigma$ is the applied stress and $S$ is the instantaneous strength. Equating Equations 15 and 16, and substituting Equations 4 and 13 for $S$, an equation can be obtained which gives the time, $t$, at which the mechanism of strength degradation changes from pit formation to crack growth. The total time to failure is then equal to $t_{p}$, plus the time, $t_{c}$, for the crack to grow to a critical size. $t$ can be detêmined from Equation 2, (using Equations 4 and 15 to evaluate the strength at which the degradation mechanism changes from pit formation to crack growth). 


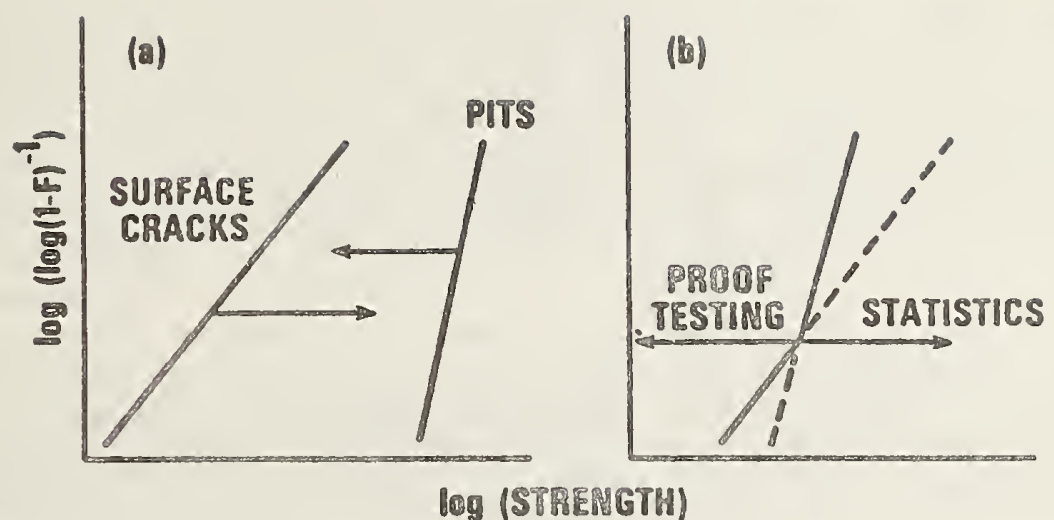

Figure 14. Schematic representation of the effect of high temperature exposure on the strength distribution: (a) initial strength distribution. Curves are assumed to move in the direction of the arrows as the exposure time is increased; (b) distribution after the flaw structure has reached a state of "equilibriurs". Proof testing or nondestructive evaluation can be used to improve. reliability at stresses lower than the point of intersection of the two lines, statistics can be used to the right of the point of intersection.

equation is obtained that relates the failure strength, $S$, to the failure probability, $F$.

With regard to lifetime prediction, the above discussion is sufficient to draw several important conclusions with regard to proof testing and nondestructive testing. At any time during exposure, the strength of components to the left of the point of intersection of the two curves shown in Figure 14 will be controlled by the initial flaw population. Those specimens that lie to the left of the intersection will contain the largest flaws and consequently will be the ones to be eliminated by proof testing or nondestructive inspection. Since the initial flaw population controls the strength in this regime, proof testing and nondestructive evaluation techniques can be used to truncate the population, and the theory presented earlier in this paper can be used to provide a conservative estimate of the component lifetime. The intersection of the two curves shown in Figure 14 provides an upper limit to the proof test load that can be usefully employed to truncate the initial flaw population. Above this load, component strength depends not on the flaws initially present in 
the component, but on those that are generated by exposure to elevated temperatures $(20,24)$.

After long periods of exposure, proof testing or nondestructive evaluation can be applied again over the entire range of strengths provided the flaw distribution (pits and cracks) has reached a static state. If, however, the distribution to the right of the intersection in Figure 14 represents a dynamic state of equilibrium, then new pits will be continuously generated as the old ones are renoved. As a consequence, nondestructive evaluation and proof testing will not be a viable lifetime prediction cechnique. For the dynamic equilibrium situation, statistical techniques such as those described earlier in this paper would have to be used for purposes of lifetime prediction. Pits generated by the oxidation process would serve as the initial flaw distribution for the lifetime prediction.

The combined effects of subcritical crack growth and pit formation on strength can be determined by considering the rate at which each of these processes degrade the strength. As long as strength degradation due to pit formation exceeds that resulting from crack growth, subcritical crack growth will not play a major role in the strength degradation process; when the converse is true, crack growth will dominate the strength degradation process. The switch from one controlling mechanism to the other will occur when the two strength degradation rates are equal.

The rate of strength degradation due to pit formation can be determined by substituting $S_{2}$ of equation 13 for $S_{0}$ of Equation 4, and differentiating with respect to time:

$$
\mathrm{dS} / \mathrm{dt}=-\beta \Delta \mathrm{S}_{\mathrm{O}_{2}}[\exp (-\beta \mathrm{t})]\left[\ln (1-\mathrm{F})^{-1}\right]^{1 / \mathrm{m}}
$$

The rate of strength degradation due to crack growth has been derived by Fuller et al. (4) and is given by the following expressicn:

$$
\mathrm{dS} / \mathrm{dt}=-\left(\mathrm{AY}^{2} \mathrm{~K}_{I C} \mathrm{n}^{\mathrm{n}-2} / 2\right)(\sigma / \mathrm{S})^{\mathrm{n}} \mathrm{S}^{3}
$$

where $\mathrm{A}$ and $\mathrm{n}$ are defined by equation $1 ; \mathrm{Y}$ is a geometric constant; $\sigma$ is the applied stress and $S$ is the instantaneous strength. Equating Equations 15 and 16, and substituting Equations 4 and 13 for $S$, an equation can be obtained which gives the time, $t$, at which the mechanism of strength degradation changes from pit formation to crack growth. The total time to failure is then equal to $t_{p}$, plus the time, $t_{c}$, for the crack to grow to a critical size. $t$ can be determined from Equation 2, (using Equations 4 and 15 to evaluate the strength at which the degradation mechanism changes from pit formation to crack growth). 
Although the mathematical scheme for obtaining the total time to failure is straightforward, the equations are not included here because of their complexity. Never-the-less, the procedure does provide a rational method of obtaining the total time to failure when pit formation plays a critical role in determining component lifetime. It is worth noting that the final equation can be expressed in terms of strength, probability and failure time. This type of representation was first suggested by Davidge et al. (33) as a method of design with ceramic materials.

\section{SUMMARY}

In this paper, a review is presented of current techniques used to evaluate the lifetime capability of structural ceramics. Three successful applications of these techniques are presented and discussed in order to demonstrate the viability of the techniques for purposes of engineering design. Finally, limitations of the techniques are discussed with regard to heat-engine applications. An extension of theory is recommended to treat crack healing and pit formation resulting from high temperature exposure.

The theory presented in this paper is based on the theory of linear-elastic, fracture mechanics. Failure of structural ceramics is assumed to be the result of subcritical crack growth from pre-existing flaws in the structural components. Lifetime predications require evaluation of the initial flaw size and of the rate at which cracks grow when subjected to applied loads. The three techniques that can be used to evaluate the initial flaw size are nondestructive evaluation, proof-testing and statistics, while the three techniques that can be used to evaluate the rate of crack growth are fracture mechanics techniques, static fatigue techniques (stress rupture) and dynamic fatigue techniques (constant loading rate to failure). The critical equations required for purposes of failure prediction are presented in the paper. Successful applications of the lifetime prediction method are illustrated for electronic-substrate ceramics, for vitreous grinding wheels and for high-purity aluminum oxide at elevated temperatures.

Potential limitations in applying the technique to heat engine ceramics, such as silicon nitride and silicon carbide, are discussed. These limitations arise because of flaw generation and flaw healing that is observed to occur in these materials at elevated temperatures. Flaw generation can be caused by a number of processes: oxidation or other environmental attack which results in surface pit formation, particle impact or component contact which results in localized stresses that nucleate cracks, and thermal shock which results in transient stresses that can result in crack formation. Flaw healing can 
be attributed to surface dissolution caused by oxidation and silicate glass formation. These processes change the initial flaw population so that failure no longer occurs from machining flaws originally present in the ceramic. In this situation the development of a model for failure prediction requires the consideration of flaw generation processes.

Extension of the theory presented in earlier sections of the paper is illustrated for the combined processes of flaw healing, pit formation and subcritical crack growth. The method independently evaluates these three processes and then determines the relative contribution of each of these processes to the total failure time. Conditions are established for proof testing of as received components. Because of the occurrence of pit formation, a maximum value for the proof test load is established, above which proof testing does not contribute to component reliability. After long term exposure, proof testing or nondestructive evaluation can be applied again provided the flaw (pit) distribution has reached a state of static equilibrium. If, however, the flaw distribution has reached a state of dynamic equilibrium, then statistical techniques must be applied for lifetime prediction. Assuming that the strength distribution of pits can be represented by a two parameter Weibull distribution, the application of statistics is discussed for the combined failure modes of pit formation and crack growth. For these conditions, equations are developed for determining the total failure time.

\section{ACKNOWLEDGEMENTS :}

One of the authors (JER) is pleased to acknowledge the support of the Office of Naval Research, Metallurgy and Ceramics Program, the other authors are pleased to acknowledge the support of the Department of Energy, Division of Fossil Fuel Utilization.

\section{REFERENCES}

1. A.G. Evans and S.M. Wiederhorn, "Proof Testing of Ceramic Materials-An Analytical Basis for Failure Prediction," Int. J. Fract., 10, 379-92 (1974).

2. S.M. Wiederhorn, "Reliability, Life Prediction, and Proof Testing of Ceramics," Pp. 635-65 in Ceramics for High Performance Applications, ed. by J. J. Burke, A.E. Gorum, and R.N, Katz, Brook Hill Pub. Co., Chestnut Hil1, MA. (1974). 
3. J.E. Ritter, Jr., "Engineering Design and Fatigue Failure of Brittle Materials," pp. 667-686 in Fracture Mechanics of Ceramics, Vo1. 4, ed. by R.C. Bradt, D.P.H. Hasselman, and F. Lange, Plenum Press, NY (1978).

4. S.M. Wiederhorn, E.R. Fuller, Jr., J.E. Ritter, Jr., and P.B. Oates, "Proof Testing of Ceramics: I. Experiment" NBSIR 79-1934; "II Theory," NBSIR 79-1944, (December 1979).

5. J.E. Ritter, Jr. and J.N. Humenik, "Static and Dynamic Fatigue of Polycrystalline Alumina," J. Mat. Sci., 14, 626632 (1979).

6. J.N. Humenik and J. E. Ritter, Jr., "Susceptibility of Alumina Substrates to stress Corrosion Cracking During Wet Processing," to be published, Bull. Am. Ceram. Soc.

7. J.E. Ritter, Jr. and S.A. Wulf, "Evaluation of Proof Testing to Assure Against Delayed Failure," BuIl. Am. Ceram. Soc. 57, 186-190 (1978).

8. R. Jakus, T. Service, and J.E. Ritter, Jr., "High Temperature Fatigue Behaviour of Polycrystalline Alumina," to be published, J. Am. Ceram. Soc.

9. S.M. Wiederhorn, E.R. Fuller, Jr., J. Mande1, and A.G. Evans, "An Error Analysis of Failure Prediction Techniques Derived from Fracture Mechanics," J. Am. Ceram. Soc. 59, 403-11 (1976).

10. D. F. Jacobs and J.E. Ritter, Jr., "Uncertainty in Minimum Lifetime Predictions," J. Am. Ceram. Soc. 59, 481-486 (1976).

11. P.N. Thorby, "Experimental Errors in Estimating Times to Failure," J. Am. Ceram. Soc. 59, 514-16, (1976).

12. S.M. Wiederhorn, "Dependence of Lifetime Predictions on the Form of the Crack Propagation Equation," PFo 893-901 in Fracture 1977, Vo1. 3, D.M.R. Taplin, Ed., University of Waterloo Press, Waterloo, Ontario, Canada (1977).

13. R.W. Rice, S.W. Freiman, and J.J. Mecholsky, Jr., "Fracture Sources in $\mathrm{Si}_{3} \mathrm{~N}_{4}$ and SiC," PP. 665 in Proceedings of the 1977 DARPA/NAVSEA Ceramic Gas Turbine Demonstration Engine, J.W. Fairbanks and R.W. Rice, Eds., Metal and Ceramics Information Center Report MCIC-78-36, Battelle Columbus Laboratories, Columbus, Ohio (1978).

14. S.W. Freiman, C. Cm. Wu, K.R. McKinney, and W.J. McDonough, PP 655-663 in ref. 13.

15. D.W. Richerson and T.M. Yonushonis, "Environmental Effects on the Strength of Silicon-Nitride Materials," pp. 247-71 in ref. 13.

16. F.F. Lange, "Evidence for Cavitation in Crack Growth," J. Am. Ceram. Soc. 62 222-3 (1979).

17. N.J. Tighe, "Structure of Slow Crack Interfaces in Silicon Nitride," J. Mater. Sci. 13, 1455-63 (1978). 
18. S.W. Freiman, A. Williams, J. J. Mecholsky and R.W. Rice, "Fracture of $\mathrm{SI}_{3} \mathrm{~N}_{4}$ and $\mathrm{SiC}$," Pp. 824-34 in Ceramic Microstructures 76, R.M. Fulrath and J.A. Pask, Eds., Westview Press, Boulder, Colo. (1977).

19. S.W. Freiman, J.J. Mecholsky, W.J. McDonough, and R.W. Rice, "Effects of Oxidation on the Room Temperature Strength of Hot-Pressed $\mathrm{Si}_{3} \mathrm{~N}_{4}-\mathrm{MgO}$ and $\mathrm{Si}_{3} \mathrm{~N}_{4}-\mathrm{ZrO}_{2}$, "pp. 1069-76 in Ceramics for High Performance Applications," J.J. Burke, E.M. Lenoe, and R.N. Katz, Brook Hill Publishing Co., Chestnut Hill, Mass. (1978).

20. S.M. Wiederhorn and N.J. Tighe, "Proof-Testing of HotPressed Silicon Nitride," J. Mat. Sci. 13, 1781-93 (1978).

21. D. Cubicciotti and K.H. Lau, "Kinetics of Oxidation of Hot Pressed Silicon Nitride Containing Magnesia," J. Am. Ceram. Soc., 61 512-7 (1978).

22. D.D. Cubicciotti, R.L. Jones, K.H. Lau, and D.J. Rowcliffe, "High Temperature Oxidation and Mechanical Properties of Silicon Nitride," Interim Scientific Report 5522-2, Nov. 15, 1978, Prepared for Air Force Office of Scientific Research/NE, SRI International.

23. T.M. Yonushonis and D.W. Richerson, "Strength of ReactionBonded Silicon Nitride," pp.219-233 in ref. 13.

24. S.M. Wiederhorn and N.J. Tighe, "Effect of Flaw Generation on Proof-Testing," pp 689-700 in ref. 13.

25. A.F. Mclean, E.A. Risher, R.J. Bratton and D.G. Miller, pp 133-134 in Brittle Materials Design, High Temperature Gas Turbine, technical report AMRC CTR 75-28 to the Army Materials and Mechanics Research Center, Watertown, Mass., October 1975.

26. J.A. Rubin, "Probable Causes of Pitting in Hot-Pressed Si $\mathrm{N}_{4}$ Ceramics," pp. 739-743 in ref. 13.

27. R. W. Davidge, A.G. Evans, A.G. Gilling and P.R. Wilgman, "Oxidation of Reaction Sintered Silicon Nitride and Effects on Strength," in Special Ceramics, 5, 329-44 (1972).

28. N.J. Tighe, to be published.

29. D.W. Richerson, private communication.

30. A.G. Evans and S.M. Wiederhorn, "Crack Propagation and Failure Prediction in Sillcon Nitride at Elevated Temperatures," J. Mat. Sci., 9 , 270-278 (1974).

31. A.G. Evans, "Fracture Mechanics Determinations," pp.17-48 in Fracture Mechanics of Ceramics, Vol. 1, R.C. Bradt, D.P.H. Hasselman and F.F. Lange, eds.. Plenum Press, New York (1974).

32. N.R. Mann, R.E. Shafer and N.D. Singpurwalla, Methods for Statistical Analysis of Reliability Data, John Wiley and Sons, New York (1974). 
33. R.W. Davidge, J.R. McLaren and G. Tappin, "Strength-ProbabilityTime (SPT) Relationships in Ceramics," J. Mat. Sci. $\underline{8}$, 1699-1705 (1973).

34. N.J. Tighe and S.M. Wiederhorn, "Fracture of Brittle Materials at High Temperatures," Air Force Materials Laboratory

Technical Report: AFML-TR-78-83, July 1978. 
NBS.114A (REV. 9.78$)$

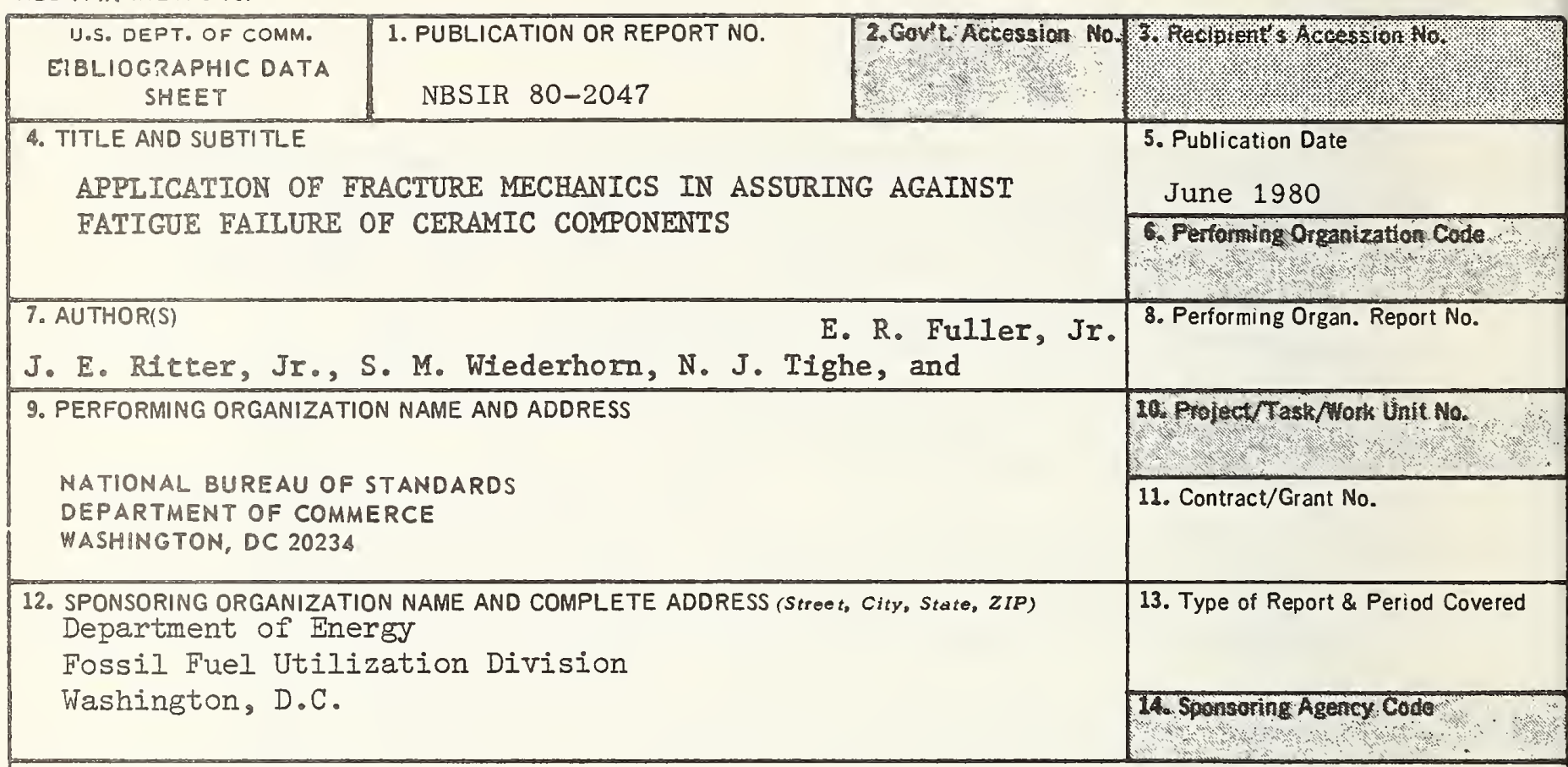

15. SUPPLEMENTARY NOTES

Document describes a computer program; SF-185, FIPS Software Summary, is attached.

16. ABSTRACT (A 200-word or less factual summary of most significant information. If document includes a significant bibliography or literature survoy, mention it hero.)

This paper will review the application of fracture mechanics theory to the prevention of delayed fallure of ceramics. Three successful applications of this theory of assuring the mechanical reliability of ceramics are discussed in order to demonstrate the viability of the theory for purposes of engineering design. Finally, a description is presented of practical limitations of the theory with regard to heat engine application. Methods of overcoming these limitations through modification of test procedures, and application of statistical theory are then presented.

17. KEY WORDS (six to twelve entries; alphabetical order; cepitalize only the first letter of the first key word unleus a proper name; separated by semicolons)

Dynamic fatigue; fracture mechanics; lifetime prediction; proof testing; stress corrosion; subcritical crack growth.

18. AVAILABILITY X. Unlimited

For Official Distribution. Do Not Release to NTIS

Order From Sup. of Doc. U.S. Government Printing Office, Wasinington, DC 20402, SD Stock No. SNOO3-C03-

Z Order From National Technical Information Service (NTIS), Springfield, VA. 22161

\begin{tabular}{|l|c|}
\hline $\begin{array}{l}\text { 19. SECURITY CLASS } \\
\text { (THIS REPORT) }\end{array}$ & $\begin{array}{c}\text { 21. NO. OF } \\
\text { PRINTED PAGES } \\
\text { UNCLASSIFIED }\end{array}$ \\
\hline $\begin{array}{l}\text { 20. SECURITY CLASS } \\
\text { (THIS PAGE) } \\
\text { UNCLASSIFIED }\end{array}$ & $\$ 6.00$ \\
\hline
\end{tabular}


NBSIR $80-2075$

IN SITU OXIDATION OF $\mathrm{Y}_{2} \mathrm{O}_{3}$-DOPED $\mathrm{Si}_{3} \mathrm{~N}_{4}$

N.J. Tighe

Fracture and Deformation Division

Nationa? Measurement Laboratory

Center for Materials Science

National Bureau of Standards

U.S. Department of Commerce

Washington, DC 20234

K. Kuroda, T.E. Mitchell, and A.H. Heuer

Case Western Reserve University

Cleveland, Ohio

Published in:

Electron Microscopy 1980

Vol. 4, High Voltage 

In Situ Oxidation of $\mathrm{Y}_{2} \mathrm{O}_{3}$-doped $\mathrm{Si}_{3} \mathrm{~N}_{4}$

N. J. Tighe, National Bureau of Standards Washington, D. C.

K. Kuroda, T. E. Mitchell and A. H. Heuer Case Western Reserve University Cleveland, Ohio

Hot-pressed $\mathrm{Si}_{3} \mathrm{~N}_{4}+8-13 \% \mathrm{Y}_{2} \mathrm{O}_{3}$ compacts, which exhibited catastrophic oxidation in air at $740^{\circ} \mathrm{C}$ but only passive oxidation at $1380^{\circ} \mathrm{C}$, were studied by HVEM using an environmental cell. The in situ experiments were started as part of a larger program to establish a model for this catastrophic oxidation process. The low temperatures required for initiation of oxidation are within the capability of the hot stage and the reaction products are sufficiently complex to require analysis by electron diffraction. This yttria-doped silicon nitride ceramic is of interest for use in ceramic turbine engine components because of its good mechanical properties at temperatures above $1200^{\circ} \mathrm{C}[1]$. However, until the cause of the low temperature catastrohpic oxidation is identified and corrected the material cannot be manufactured successfully for these components. The low temperature oxidation is similar in appearance to the so-called "pest condition" and occurs in some billets and not in others which were manufactured under the same apparent commercial, powder processing and hot pressing conditions. Lange et a . [2] found that billets they prepared in the $\mathrm{Si}_{3} \mathrm{~N}_{4}-\mathrm{Si}_{2} \mathrm{~N}_{2} \mathrm{O}-\mathrm{Y}_{2} \mathrm{Si}_{2} \mathrm{O}_{7}$ compatibility triangle of the phase equilibrium diagram, shown in Fig. 1, were oxidation resistant; and, that billets with compositions outside this triangle were unstable in oxidizing conditions.

In this paper, the material designated -A- exhibited only passive oxidation during heating in air from $600^{\circ} \mathrm{C}$ to $1400^{\circ} \mathrm{C}$; whj $1 \mathrm{e}$ the material 
designated -B- exhibited catastrophic oxidation during heating in air at $740^{\circ} \mathrm{C}$. Both billets ${ }^{*}$ were from the same manufacturer [3] but were purchased at different times. A bar of material -B- when heated in a gradient furnace from $735^{\circ} \mathrm{C}$ to $1380^{\circ} \mathrm{C}$ for 20 hours oxidized catastrophically at the low temperature end, and passively at the high temperature end. The major crystalline phases in both materials were identifled by powder $x \rightarrow$ ray diffraction as $\mathrm{BSI}_{3} \mathrm{~N}_{4}, \mathrm{Y}_{10} \mathrm{Si}_{7} \mathrm{O}_{23} \mathrm{~N}_{4}$ (H phase) and $\mathrm{WSi}_{2}$ (there were some unidentified lines). The tungsten phase (3-4\%) is a result of contamination from WC balls used in ball-milling of the silicon nitride powder, and thus is a common impurity phase in hot-pressed $\mathrm{Si}_{3} \mathrm{~N}_{4}$. The WSi 2 phase was not present in the castrophically oxidized portion of the material B, but was present in the portion oxidized at $1380^{\circ} \mathrm{C}$. Although the compositions of $A$ and $B$ were similar, there was considerable phase segregation and inhomogeneity in material $B$ as seen in the light microscope. Both materials appear to have compositions outside the compatibility triangle discussed by Lange et al. [2].

The Swann enviromental cell in the CWRU $550 \mathrm{kV}$ electron microscope was used with a platinum strip heater, in flowing oxygen. Specimens of materials $-A$ - and $-B$ - were prepared as ion-thinned discs with one flat side and one dished side. This configuration gave good contact with the grid heater; and, resulted in better heat conduction to the specimen.

The microstructure of the yttria -A- is shown in Fig. 2, and is similar to that found in other billets $[4,5]$. The large tabular grains are $\mathrm{Si}_{3} \mathrm{~N}_{4}$, the triangular shaped phases surrounding the grain corners are the $\mathrm{Y}_{2} \mathrm{O}_{3}+\mathrm{Si}_{3} \mathrm{~N}_{4}$ phases and the dark particles along the grain boundaries are the $\mathrm{WSi}_{2}$ and/or WC phases. During hot-pressing at $1750-1800^{\circ} \mathrm{C}$, 


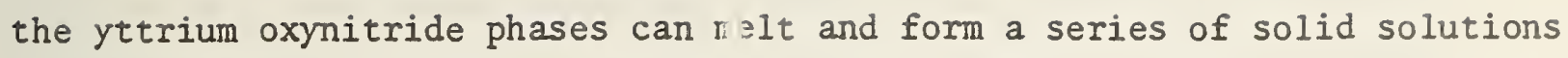
with the impurity phases and with the silica in the starting powder [5]. Both crystalline and non-crystalline phases of variable composition can fill the interstices around $\mathrm{Si}_{3} \mathrm{~N}_{4}$ grains.

Specimens were heated gradually to $750^{\circ} \mathrm{C}$ in 40 torr of $0_{2}$. Under these conditions oxide platelets were seen to nucleate on the surfaces of the $\mathrm{BSi}_{3} \mathrm{~N}_{4}$ grains, around holes and at the yttria phases as in Fig. 3. The platelets, which were randomly oriented and incoherent with the matrix, gave spotty ring patterns both at temperature and after cooling to room temperature. The platelets in Fig. 4 were identified from these ring patterns as a mixture of $\mathrm{SiO}_{2}$ and $\mathrm{Si}_{2} \mathrm{~N}_{2} \mathrm{O}$. During the oxidation considerable drift and flexure of the specimens occurred, as is evident in the figures.

After a few minutes of heating, cracks appeared along some grain boundaries; and, as oxidation proceeded a fiim was observed to grow by the merging of nucleating clusters. These clusters changed diffraction contrast as they merged. It is assumed at this time, that this process represented the gradual reaction and volatilization of the tungsten rich phase. The film thickened and the crack widened to form a sizeable hole as seen in Fig. 5. Iron rich and tungsten depleted phases around reacted thin foil edges were detected with an EDX system on a $200 \mathrm{KV}$ instrument [7].

The yttria-silicon oxynitride phases became porous during the in situ oxidation. This type of reaction can be seen at $Y$ in Fig. 5 and in Fig. 6. The morphology of the phases suggests that the initial, yttriarich regions were multiphase or possibly an amorphous-crystalline mixture. The phase in Fig. 6 was identified from its electron diffraction pattern as $\mathrm{YSiO}_{2} \mathrm{~N}$ or the $\mathrm{K}$-phase of Fig. 1 . 
The in situ specimens were bent and slightly pink when removed

from the strip heates. Later TEM examination showed that the oxidation had not occured uniformly over the entire thin area of the specimens. Some of the differences reflect temperature gradient and oxygen partial pressure differences between parts of the specimen that are exposed through holes in the grid heater and other parts of the specimen that were under the grid bars. In the region shown in Fig. 7 few oxide platelets are seen, and the boundaries between $\mathrm{Si}_{3} \mathrm{~N}_{4}$ grains have opened. The yttria phase visible on one edge of the grain was identified as $\mathrm{Y}_{4} \mathrm{Si}_{2} \mathrm{O}_{7} \mathrm{~N}_{2}$ or the $\mathrm{J}$ phase. The oxidation rate differences could reflect also the inhomogenity of the phase distribution mentioned previously.

Additional in situ experiments are needed to verify the mechanism of the loss of $W$ and the observed reaction differences. Video or cine' recording will be used to make a more complete record of the observations.

The results of the in situ experiments demonstrate that: castrophic low temperature oxidation in yttrla-silicon material -B- started at surfaces exposed to oxygen; volatilization of a $\mathrm{W}$ containing phase created voids; continuous films were produced over some grains; yttria rich phases became porous; and considerable strain was associated with the oxidation.

References

1. G. E. Gazza, J. Amer. Ceram. Soc. 56, 662 (1973).

2. F. F. Lange, S. C. Singhal and R.C. Kuznicki, Westinghouse Report 76-904 (1976)

3. The Norton Co. Material Designation NCX-34.

4. D. R. Clarke and G. Thomas, J. Amer. Ceram. Soc. 60 491-5 (1978). 
5. O. L. Krivanck, T. M. Shaw and G Thomas, J. Amer. Ceram. Soc., 62, 585-89 (1979) .

6. K. H. Jack in Nitrogen Ceramics, F. L. Riley ed. Noordhoff, 1977, p. 109-125.

7. G. Nord, USGS, Reston, Va.

This work is supported partially by DOE Office of Coal Utilization under Task Order No. A0861PS and by AFOSR grant 49620-78C-0053. The material -Bwas supplied by J. Wimmer of Garrett AiResearch, Phoenix, Az. 


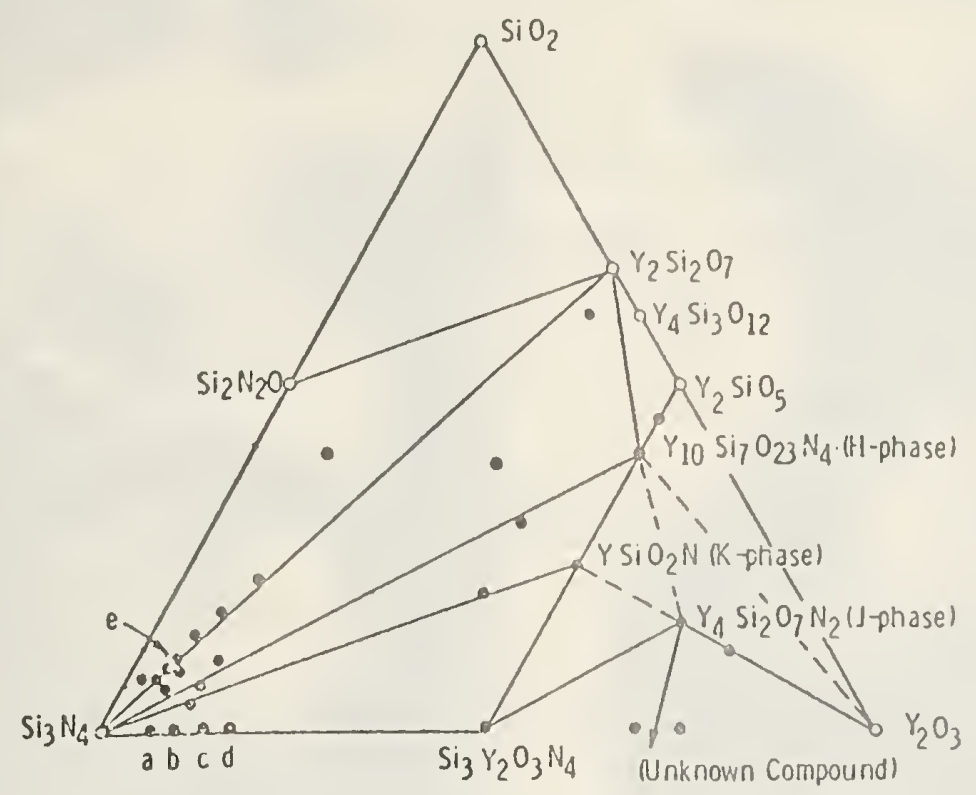

Fig. 1. Phase diagram for the yttria sialons [1].

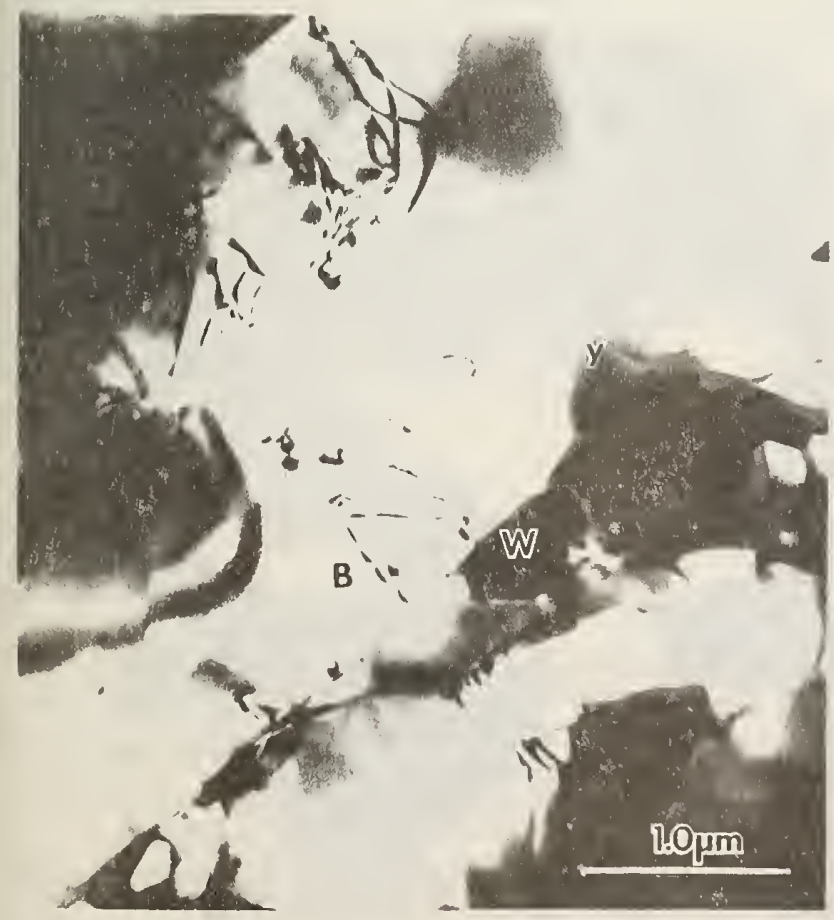

Fig. 2. Microstructure of hot-pressed $\mathrm{Si}_{3} \mathrm{~N}_{4}+8 \% \mathrm{Y}_{2} \mathrm{O}_{3}$ showing $\mathrm{BSi}_{3} \mathrm{~N}_{4}(\beta)$, grains $Y \mathrm{Si}_{10} \mathrm{O}_{2} \mathrm{~N}_{4}$ phase $(Y)$ WSi particles $(W)$.

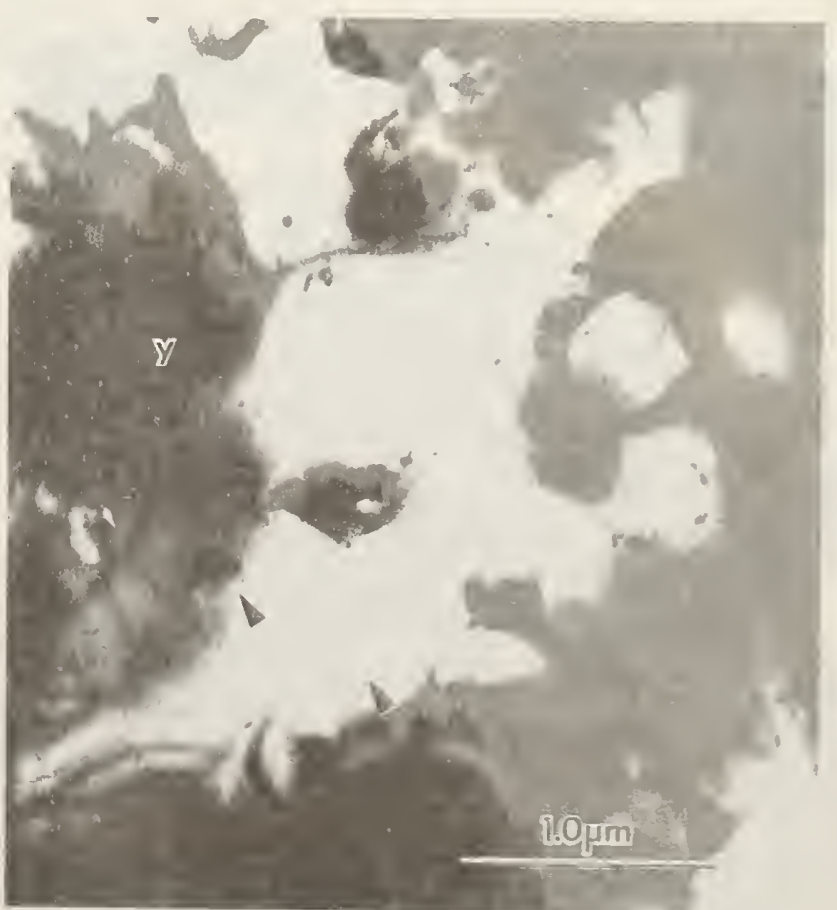

Fig. 3. Material - B - at $750^{\circ} \mathrm{C}$ in 5200 Pa after heating for $\sim 5$ min., showing oxide platelets (arrowed) and reacting yttria phase (Y). 


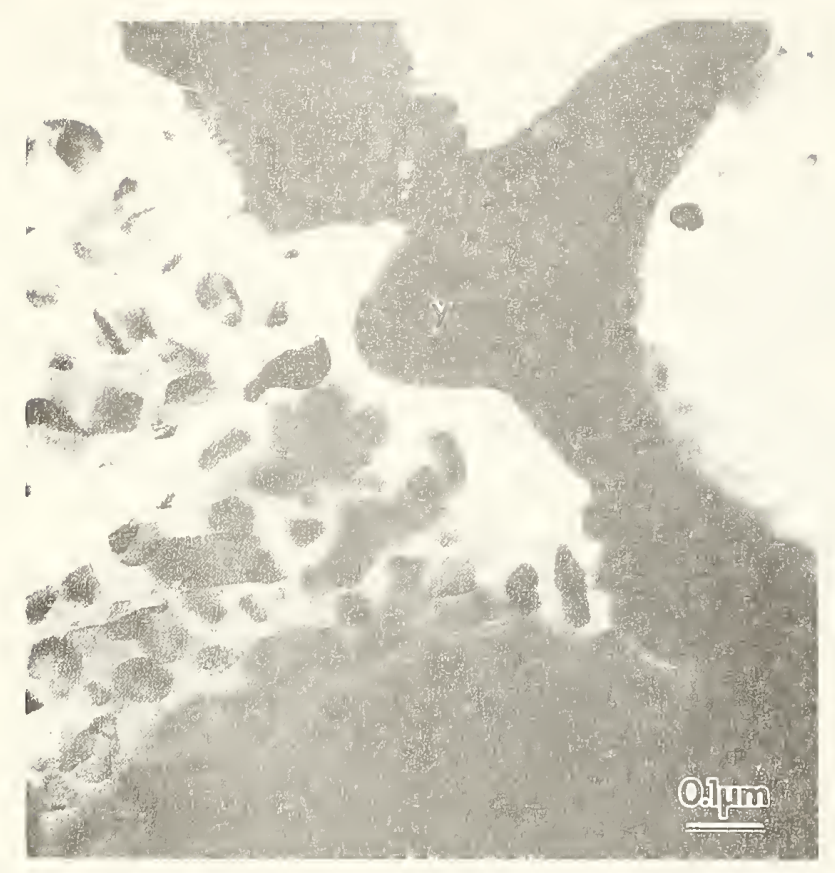

Fig. 4. $\mathrm{BSi}_{3} \mathrm{~N}_{4}$ grain with $\mathrm{SiO}_{2}$ and $\mathrm{Si}_{2} \mathrm{~N}_{2}$ platelets produced during in situ oxidation. Yttria phase at Y. (Material-B-)

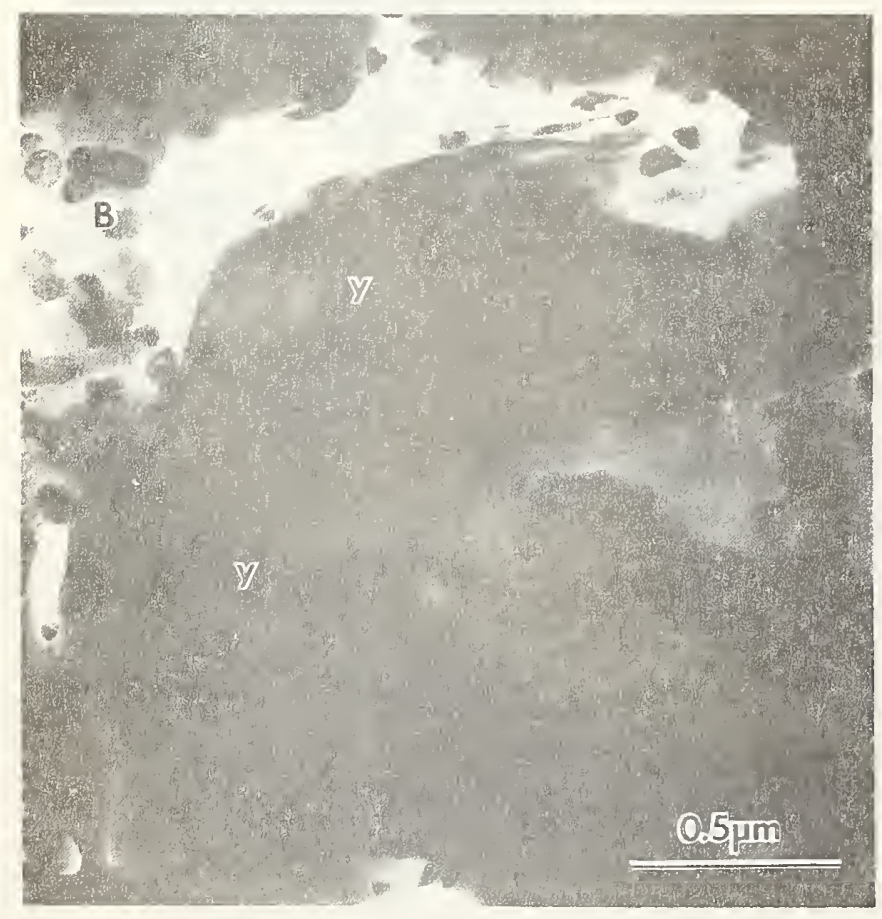

Fig. 6. Materiat-B-. After oxidation the yttria phase $(Y)$ is porous and layered, $\mathrm{BSi}_{3} \mathrm{~N}_{4}$ gains (B) have oxide platelets.

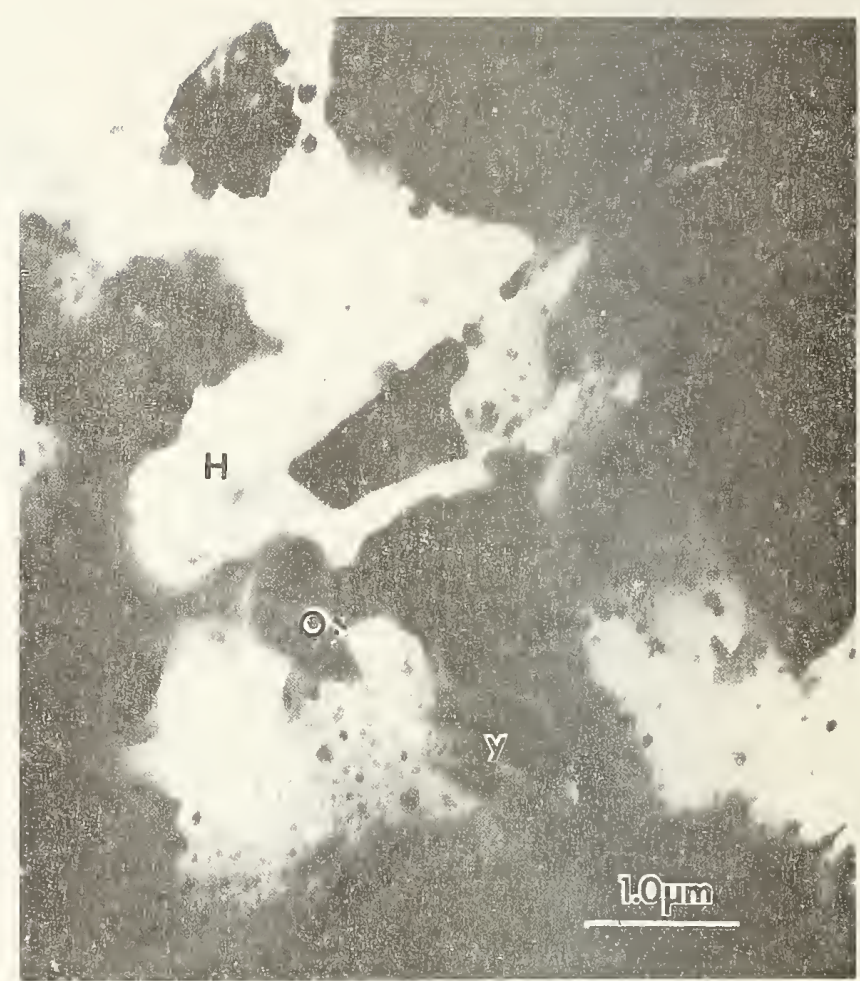

Fig. 5. Specimen at $750^{\circ} \mathrm{C}$ in $5300 \mathrm{~Pa} \mathrm{O} 2$ The hole $(\mathrm{H})$ and the $\mathrm{film}$ around it $(\mathrm{Ox})$ were produced in $230 \mathrm{~min}$ (Material-B-).

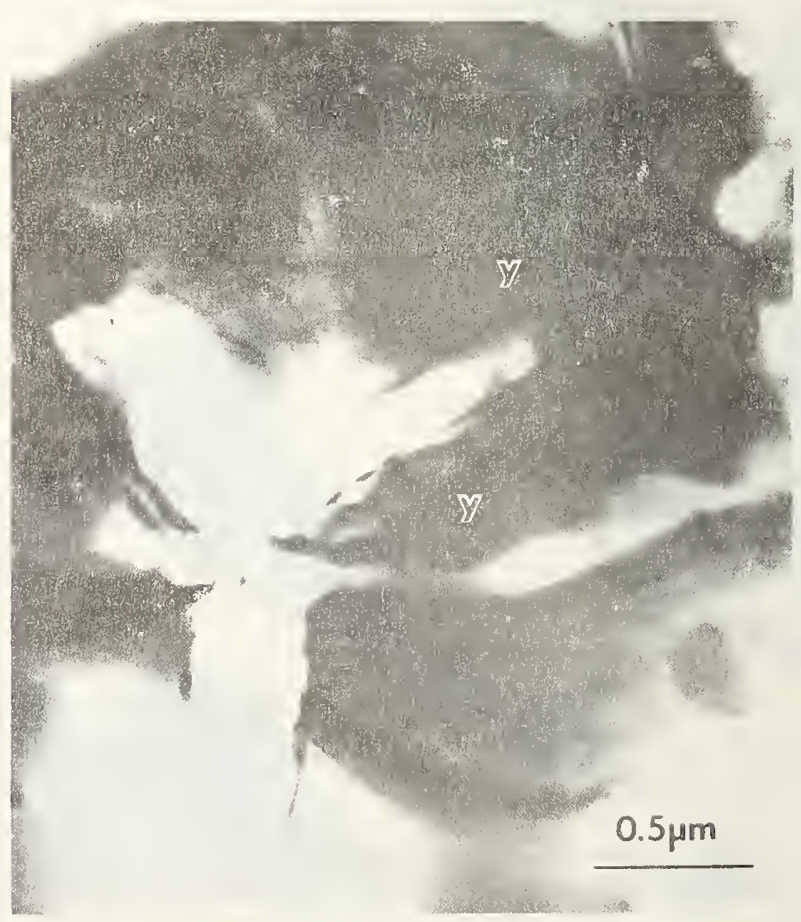

Fig. 7. Portion of in situ specimen which was under the grid, yttria phase $(Y)$ is $\mathrm{Y}_{4} \mathrm{Si}_{2} \mathrm{O}_{7} \mathrm{~N}_{2}$. 


\begin{tabular}{|c|c|}
\hline $\begin{array}{c}\text { U.S. DEPT. OF COMM. } \\
\text { HIBLIOGRAPHIC DATA } \\
\text { SHE-T }\end{array}$ & $\begin{array}{c}\text { 1. PUBLICATION OR REPORT NO. } \\
\text { NRSIR } 80-2075\end{array}$ \\
\hline
\end{tabular}

4. TITLE AND SUBTITLE

In Situ Oxidation of $\mathrm{Y}_{2} \mathrm{O}_{3}$-doped $\mathrm{Si}_{3} \mathrm{~N}_{4}$

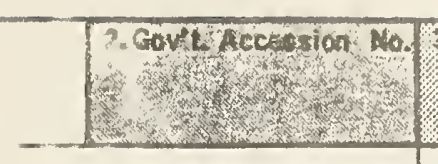

5. Publication Date

August 1980

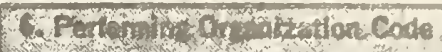

8. Performing Organ. Report No.

\section{AUTHOR(S)}

N.J. Tighe, K. Kurodo, T.E. Mitchell, A.H. Heuer

\section{PERFORMING ORGANIZATION NAME AND ADDRESS}

\author{
NATIONAL BUREAU OF STANDARDS \\ DEPARTMENT OF COMMERCE \\ WASHINGTON, DC 20234
}

12. SPONSORING ORGANIZATION NAME AND COMPLETE ADDRESS (Street, Clty, state, zIP)

Department of Energy

Office of Coal Utilization

Washington, D.C.

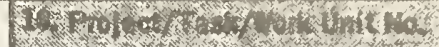

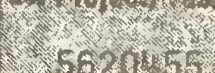

11. Contract/Grant No.

13. Type of Report \& Period Covered Interim Report April 1980

16 soneonith Areacy cada

\section{SUPPLEMENTARY NOTES}

1 Document describes a computer program; SF-185, FIPS Software Summary, is attached.

16. ABSTRACT (A 200-word or less factual summary of most olgniflcant Information. If document includes a signilicant bibliography os llterature survey, montion it here.)

Specimens of $\mathrm{Y}_{2} \mathrm{O}_{3}$-doped $\mathrm{Si}_{3} \mathrm{~N}_{4}$ were oxidized in an environmental cell in a $600 \mathrm{kV}$ electron microscope. This ceramic oxidizes passively at temperatures greater than $1000^{\circ} \mathrm{C}$ but oxidizes catastrophically at $\sim 750^{\circ} \mathrm{C}$. The in situ experiments showed that oxidation occums by nucleation and growth of $\mathrm{SiO}_{2}$ and $\mathrm{Si}_{2} \mathrm{~N}_{2} \mathrm{O}$ on the $B \mathrm{Si}_{3} \mathrm{~N}_{4}$ surfaces and by volatilization of $W$ inclusions. The paper discusses the HVEM methodology and the oxidation results.

17. KEY WORDS (six to twelve ontries; alphabotical order: capitallze only the first letter of the first key word unleas a proper namo: separated by semicolono)

Ceramic; high voltage electron microscopy; in situ; oxidation; silicon nitride; yttria-doped silicon nitride

18. AVAILABILITY X Unlimited

For Official Distribution. Do Hot Release to NTIS

Order From Sup. of Doc., U.S. Government Printing Office, Washington, DC 20402, SD Stock No. SNO03-003.

X. Order From National Technical Information Service (NTIS), Springfield, VA. 22161

\begin{tabular}{|l|c|}
\hline $\begin{array}{l}\text { 19. SECURITY CLASS } \\
\text { (THIS REPORT) }\end{array}$ & $\begin{array}{c}\text { 21. NO. OF } \\
\text { PRINTED PAGES } \\
\text { UNCLASSIFIED }\end{array}$ \\
\hline $\begin{array}{l}\text { 20. SECURITY CLASS } \\
\text { (THIS PAGE) }\end{array}$ & $\begin{array}{l}\text { 22. Price } \\
\text { UNCLASSIFIED }\end{array}$ \\
\hline
\end{tabular}



NBSIR 79-7960 (R) (DOE)

EFFECT OF STRAIN RATE ON THE

FRACTURE TOUGHNESS OF SILICON

NITRIDE AT $1400^{\circ} \mathrm{C}$

R.J. Fields, N.J. Tighe, and E.R. Fuller, Jr.

Fracture and Deformation Division

National Measurement Laboratory

Center for Materials Science

National Bureau of Standards

U.S. Department of Commerce

Washington, DC 20234

October 1979 



\section{ABSTRACT}

The critical stress intensity factor for fracture, $K_{I C}$, was measured In $\mathrm{Si}_{3} \mathrm{~N}_{4}$ at $1400^{\circ} \mathrm{C}$ as a function of strain rate. It was found that $\mathrm{K}_{\mathrm{IC}}$ increased with decreasing rates of bending of notched bars. This effect could be approximately predicted using a time dependent plastic zone correction to $\mathrm{K}_{\mathrm{IC}}$. 



\section{INTRODUCTION}

At very high temperatures, ceramics can deform extensively by time dependent deformation processes 1ike creep. This permanent deformation is stress and time dependent and is not predicted by elasticity theory. Whether or not it is appropriate to apply linear elastic fracture mechanics to creeping materials depends mainly on the extent of creep deformation relative to certain specimen dimensions. With this in mind, the strain rate dependence of the fracture toughness of silicon nitride was investigated at $1400^{\circ} \mathrm{C}$.

Work on silicon nitride, ${ }^{1}$ aluminum oxide, ${ }^{2}$ and silicon carbide ${ }^{3}$ have shown that at high temperatures and at moderate to slow strain rates, the fracture toughness is above the room temperature value by a factor of two or more. Under the same conditions, these materials are observed to creep. 3,4 It is believed that it is this creep deformation which is mainly responsible for the increased toughness. Since the stress at which creep deformation is observed is highly rate sensitive, there should be a correspondingly strong dependence of the high temperature $\mathrm{K}_{\mathrm{IC}}$ on strain rate or loading rate. Figure 1 shows the toughness of silicon nitride measured by various researchers as a function of temperature. Two groups find a strong increase in $\mathrm{K}_{\mathrm{IC}}$ with temperature, and two groups find no increase or even a slight decrease. The fracture was in all cases a fast fracture; that is, the specimen broke in two under its own elastic strain energy and the load dropped immediately to zero, faster than the loading or straining system could follow. The main difference in these results is the rate at which the tests were carried out. In impact loading studies with displacement rates greater than 100 $\mathrm{mm} / \mathrm{sec}$, no enhanced toughness was observed; whereas, increased toughness 


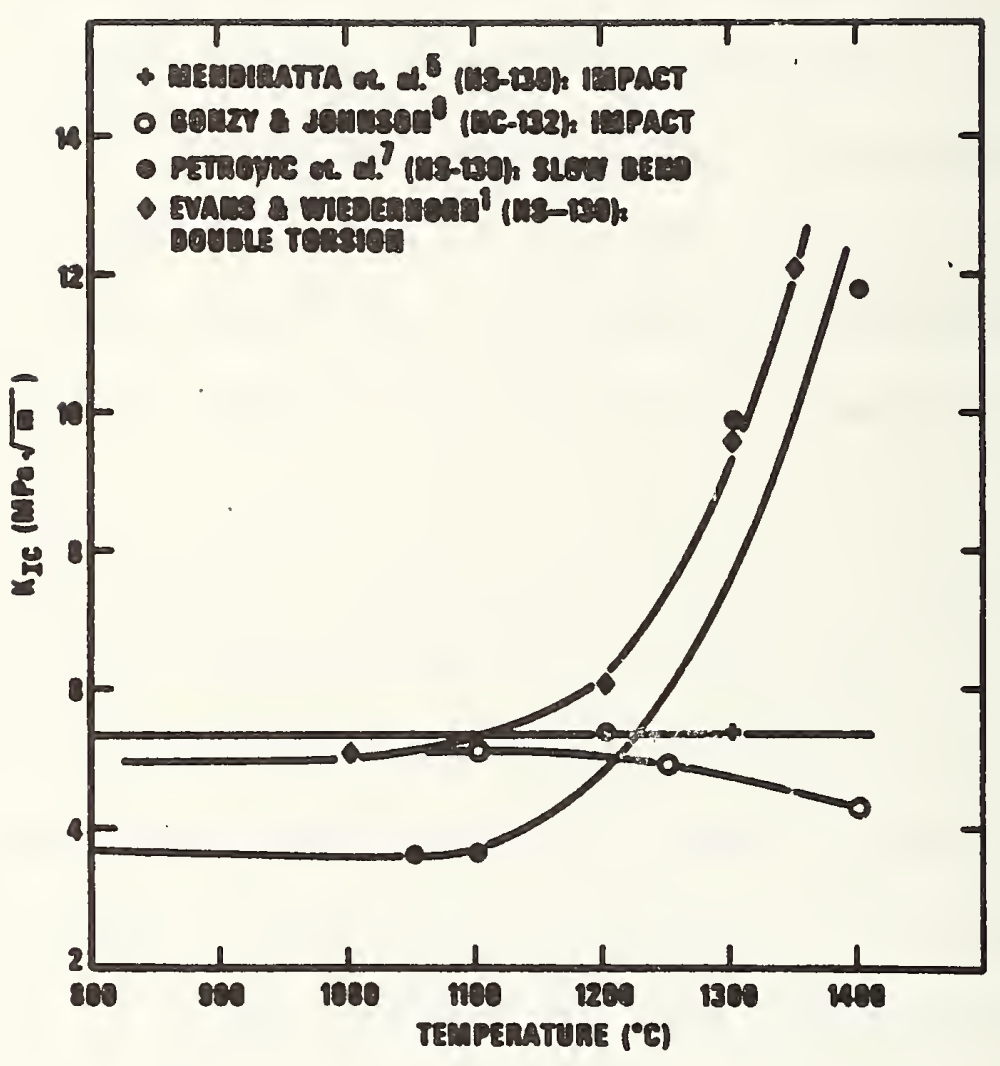

FIg. I. Effect of Temperature and Strain Kate on the rracture Toughness of Silicon Nitride as Measured by Various Researchers. 
was observed for slow bend tests or double torsion tests carried out at a displacement rate of $1 \mathrm{~mm} / \mathrm{sec}$ or less. Such a rate effect is observed in metals at much lower temperatures ${ }^{8}$ and is generally ascribed to the rate dependence of the yield stress. In such cases, a plasticity correction can be made to $\mathrm{K}_{\mathrm{IC}}$ to predict with some success the effect of rate on toughness. 9 In the present paper, the effect of strain rate on both the fracture toughness and the stress for the onset of creep is mez:-:red for silicon nitride at $1400^{\circ} \mathrm{C}$. The creep stress data is used to predict the influence of strain rate on toughness.

2. EXPERIMENTAL PROCEDURE

Bars having a rectangular cross-section were cut from a billet of NCX34, yttria doped silicon nitride. A narrow notch was introduced using a $1 / 2 \mathrm{~mm}$ thick diamond slitting wheel. Two sizes of bars were tested having the approximate dimensions listed in Table (1). The tests were performed in four point bending (See Figure 2) using a rig made of silicon carbide. The major span was $40 \mathrm{~mm}$ and the minor span was $10 \mathrm{~mm}$. All tests were performed in air in furnaces which were brought to temperature $\left(1400^{\circ} \mathrm{C}\right)$ in about 3 hours. The furnaces had feed-throughs in the top and bottom for silicon carbide push rods. One push rod was attached to a load cell and the other to the cross-head of a displacement-rate controlled testing machine. The cross-head was driven at rates from 1.25 to $0.005 \mathrm{~mm} / \mathrm{minute}$

In general, a subcritical crack initiated stably from the slit and grew a few millimeters before fast fracture occurred. This avoided ambiguities associated with the sharpness of the slit and eliminated the need to precrack or fatigue crack the specimen. For fracture tests at rapid displacement rates or at room temperature, where little or no subcritical crack growth occurs, relatively long pre-cracks were sometimes grown in by bending at $1400^{\circ} \mathrm{C}$ with a displacement rate of $0.0125 \mathrm{~mm} / \mathrm{min}$. After producing these cracks, the specimens were kept at temperature unloaded for at least one hour before cooling or testing. 
Table 1

Nominal Specimen Dimensions (mm)

\begin{tabular}{|l|c|c|}
\hline & Large Specimen & Small Specimen \\
\hline Length, $\ell$ & 52 & 52 \\
Width, W & 10 & 5 \\
Thickness, t & 5 & 4.5 \\
Slit depth, c & 3 and 5 & 1.5 \\
\hline
\end{tabular}




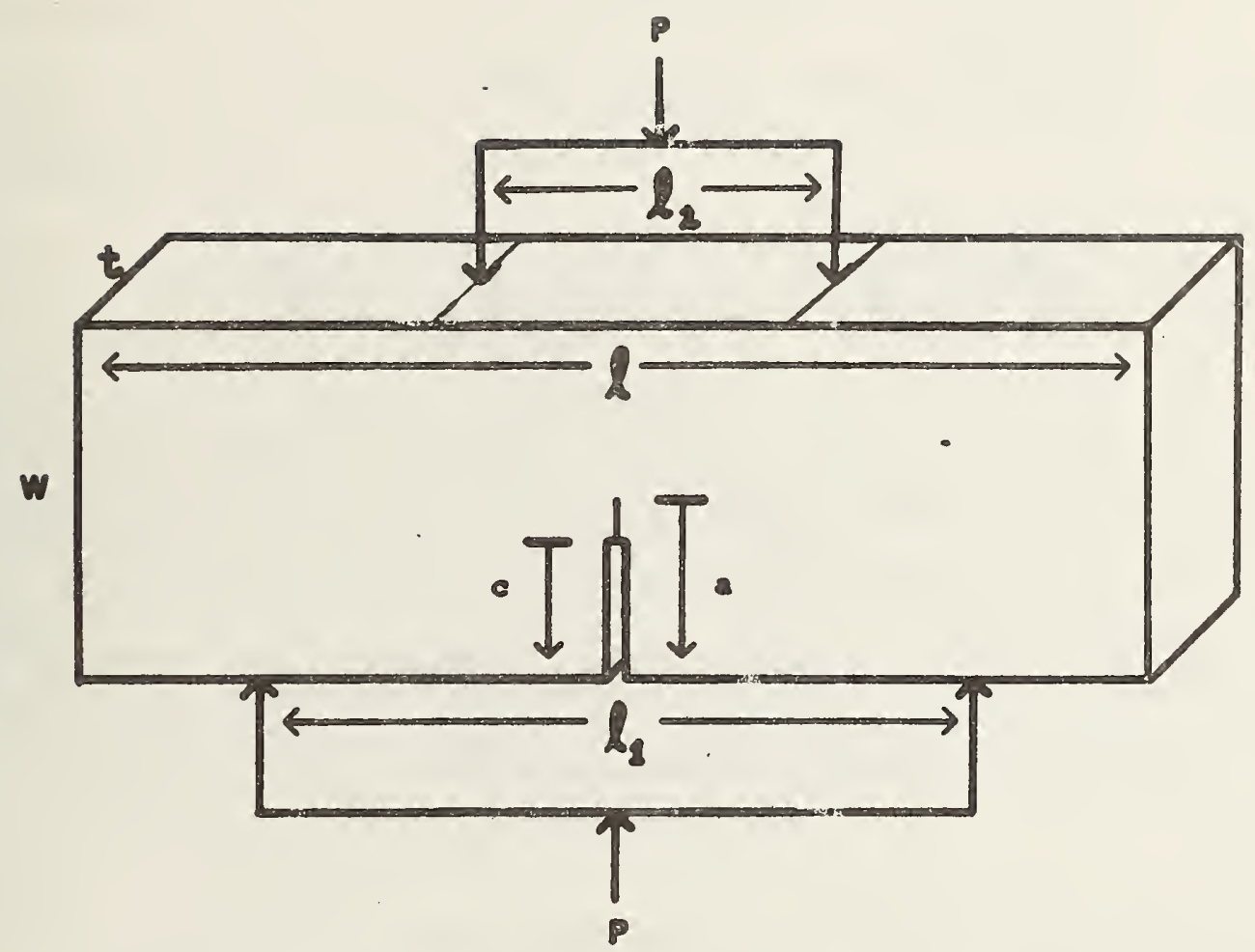

F1g. 2. Schematic of Four-Point Notched Bend Test. 
After fracture, the crack length(a) was determined as the sum of slit depth plus the extension resulting from the subcritical crack growth. This, together with the load at the onset of fast fracture $\left(P_{f}\right)$ was used to calculate $R_{I C}$ according to the formula 10

$$
K_{I C}=\frac{3 P_{f}\left(l_{1}-l_{2}\right)}{2 B W^{2}} \sqrt{\pi a} \quad F(a / W)
$$

where

$$
F(a / W)=\frac{\sqrt{2 W}}{\pi a} \tan \frac{\pi a}{2 W} \quad \frac{0.923+0.199\left(1-\sin \frac{\pi a}{2 W}\right)^{4}}{\cos (\pi a / 2 W)}
$$

and where $\ell_{1}$ and $\ell_{2}$ are the major and minor spans of the four point bending rig, $B$ is the specimen thickness, and $W$ is the specimen width. This formula was used rather than the more common polynomial 11 because it is purported to be accurate for any crack length/specimen width (a/W) ratio. The polynomial expression is only good for (a/W) less than or equal to 0.6 .

Additionally, two other types of fracture tests were performed. One test consisted of slowly growing a crack at a displacement rate of $0.0125 \mathrm{~mm} / \mathrm{min}$., waiting a time $(\Delta t)$, and then fracturing at a faster displacement rate of $1.25 \mathrm{~mm} / \mathrm{min}$. This test was performed for various $\Delta t^{\prime} s$. The other type of test consisted of growing in a crack at 0.0125 $\mathrm{mm} / \mathrm{min}$ and then cooling under load to room temperature and fracturing at $0.05 \mathrm{~mm} / \mathrm{min}$.

To describe the influence of displacement rate on the fracture behavior, the creep behavior of this particular material was needed. We made the assumption here that the creep behavior would correlate well with the stresses at which the load-deflection curves became non-linear. These proportional limit stresses were obtained for displacement rates From 0.125 to $0.0125 \mathrm{~mm} / \mathrm{min}$. Small cubes ( $5 \mathrm{~mm}$ on a side) were cut 
from some of the fracture bars. These were compressed between the silicon carbide push rods. Cross-head displacements agreed with dimensional changes measured on the specimens after the test. No attempt was made to reach steady-state creep. It is known that creep behavior of ceramics is very different in tension and compression. 4 However, the primary stage of creep is probably dominated by some viscous component like grain boundary sliding rather than a cavitational component (which dominates tertiary creep) in the material's mechanical behavior. ${ }^{12}$ This viscous deformation should not depend strongly on the sign of the loading.

To Investigate the extent of creep deformation in the fracture process, a fine array of Vicker's Indentations was made on the side of a flexural specimen (Fig. 3) which was then loaded at a displacement rate of $0.0125 \mathrm{~mm} / \mathrm{min}$. The positions of the indentations were measured before and after with a precision of $0.0075 \mathrm{~mm}$.

3. RESULTS

The $\mathrm{K}_{\mathrm{IC}}$ measured at room temperature for a specimen which was precracked at $1400^{\circ} \mathrm{C}$ was $8.3 \mathrm{MPa} \sqrt{\mathrm{m}}$. This high value is discussed in the next section. The results of measuring $\mathrm{K}_{\mathrm{IC}}$ at $1400^{\circ} \mathrm{C}$ as a function of displacement rate are shown in Fig. 4. This shows an increase in toughness from about the room temperature value to more than $18 \mathrm{MPa} \sqrt{\mathrm{m}}$ at the lowest displacement rate of $0.0125 \mathrm{~mm} / \mathrm{min}$. Evidence that this toughening is due to a time dependent process, is shown in Fig. 5. A specimen was loaded slowly until a crack started growing slowly. The specimen was unloaded rapidly and then reloaded at $1.25 \mathrm{~mm} / \mathrm{min}$. If the reloading took place immediately, the toughness value is close to that obtained by breaking the specimen at the slow rate. If the specimen was allowed to remain unloaded for several minutes before reloading, the toughness fel1. The maximum effect of delayed reloading was obtained in abcut óo minutes after which time the toughness no longer decreased. This effect 


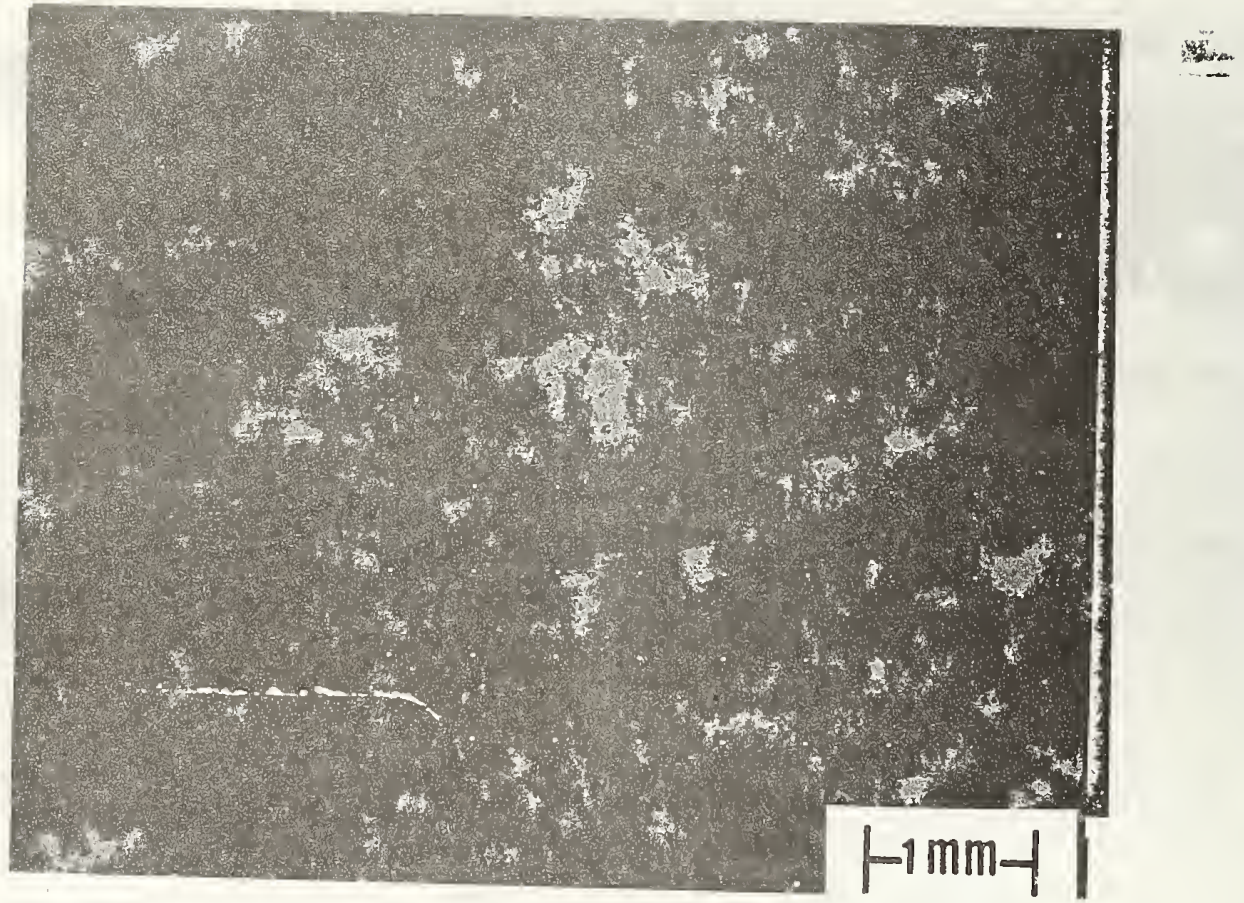

Fig. 3. Array of Vicker's Incentations on Side of Flexural Specimen. 


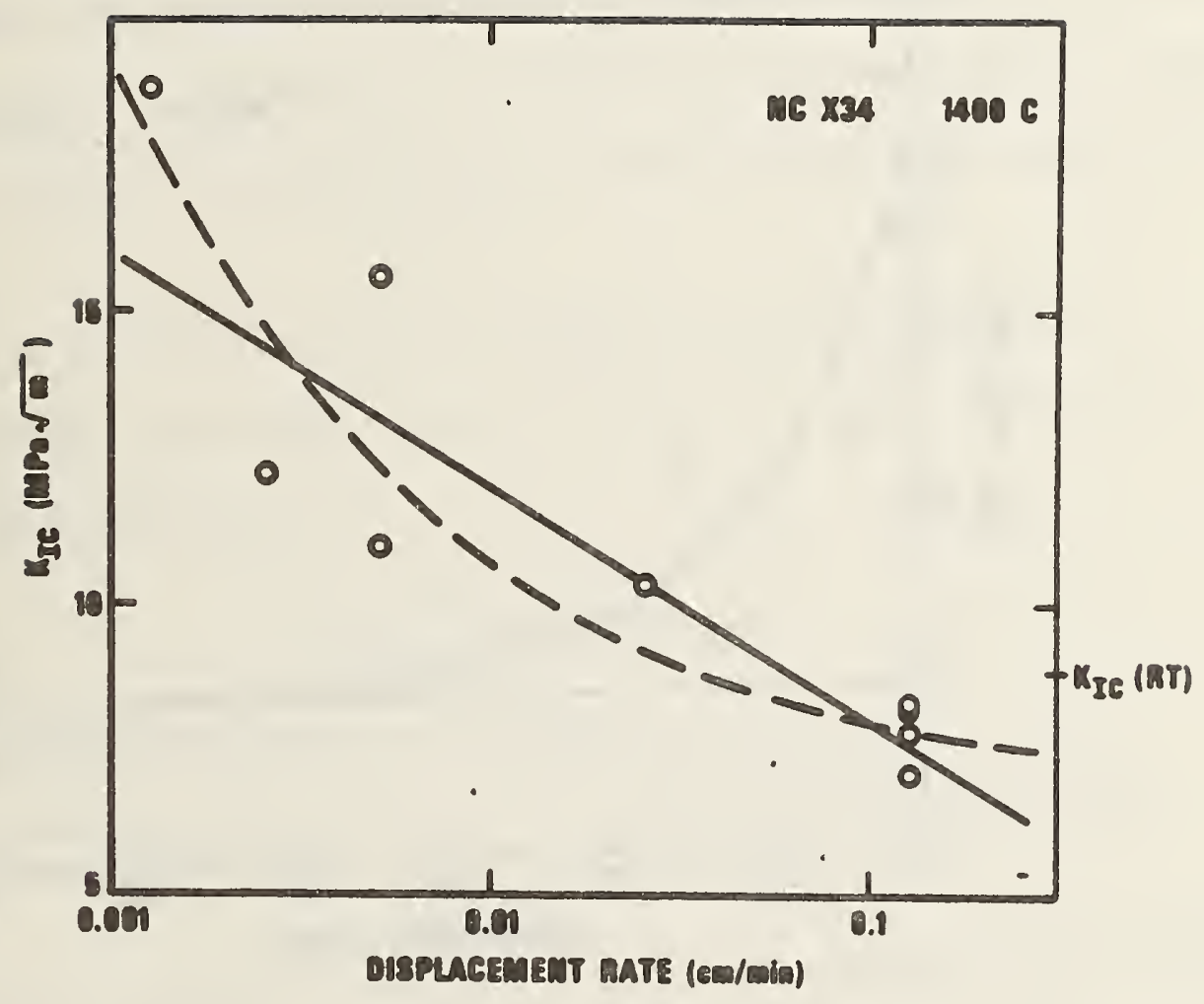

F1g. 4. Fracture Toughness of NCX34 as a Function of Cross-Head Displacement Rate at $1400^{\circ} \mathrm{C}$. 


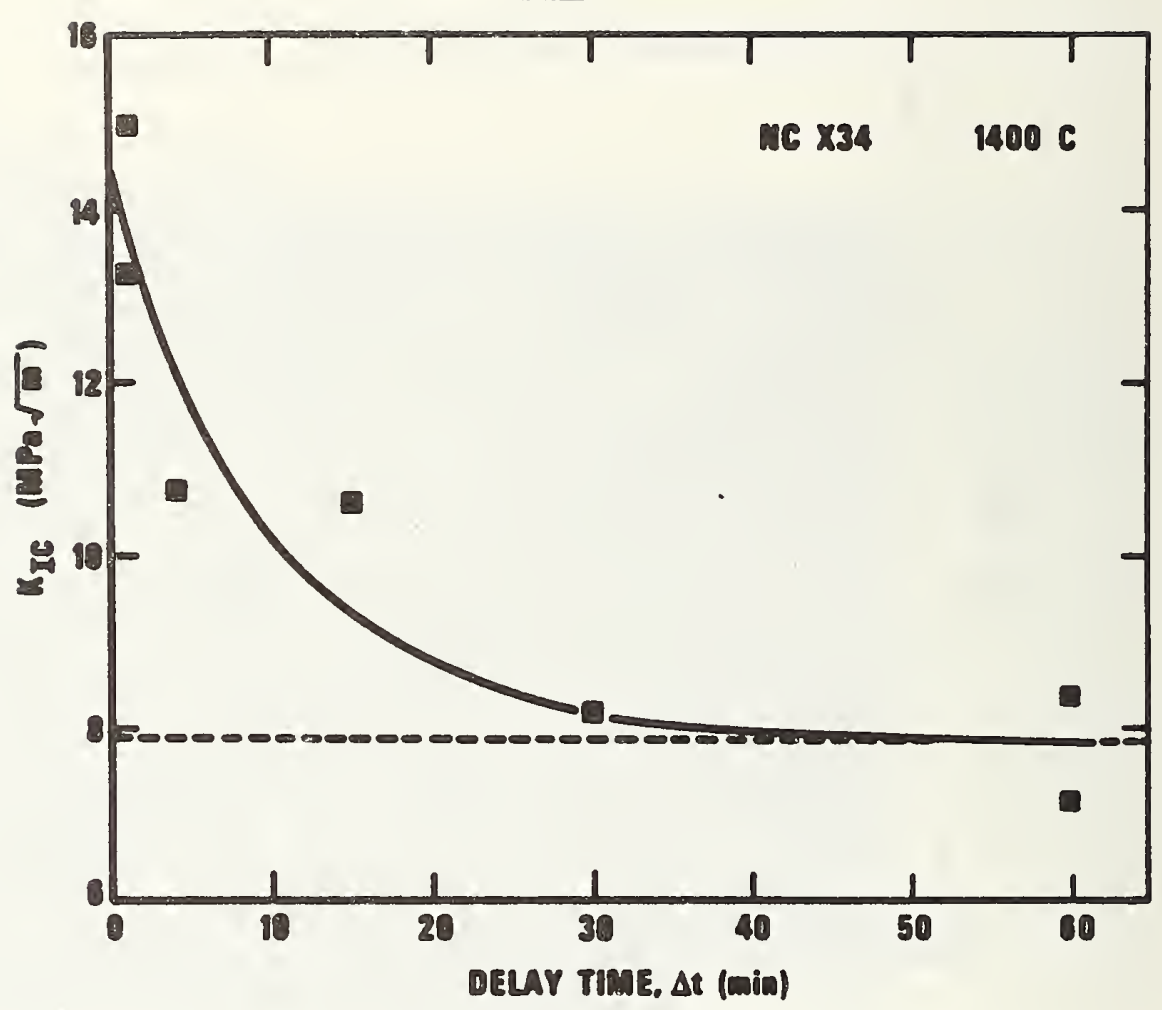

F1g. 5. Decrease in High Temperature Toughness with Time after High Temperature Pre-cracking. 
was obtalned in specimens which had been heated to $1400^{\circ} \mathrm{C}$ for several hours as well as in the as-ground specimens.

In an attempt to "freeze-in" the cause of the toughening, a specimen was loaded until a crack began to grow subcritically and then was cooled under a slightly reduced load to room temperature. This resulted in a room temperature $\mathrm{K}_{\mathrm{IC}}$ of $9.9 \mathrm{MPa} \sqrt{\mathrm{m}}$ which is a $20 \%$ increase in toughness. Tests like this on alumina have obtained similar increments in room temperature toughness. ${ }^{2}$

The results of the creep tests are shown in Fig. 6.* From this data, the relation between the strain rate and the stress at the onset of creep may be represented by

$$
\dot{\varepsilon}=\sigma_{p l} \tau^{4.24} /(2.04 \mathrm{GPa} \mathrm{sec})
$$

where the pre-exponential term and the power were determined from a least squares analysis of the data. The correlation coefficient was 0.96

The extent of permanent creep deformation was determined approximately from the flexural specimens on whose side faces an array of indentations had been made. Within the resolution of the technique $(0.075 \mathrm{~mm}$ in $10 \mathrm{~mm})$, the permanent deformation was confined to a 1 to $2 \mathrm{~mm}$ region around the crack.

4. DISCUSSION

The room temperature value for $\mathrm{K}_{\mathrm{IC}}, 8.3 \mathrm{MPa} \sqrt{\mathrm{m}}$, is higher than that usually reported for $\operatorname{NCX} 34.13$ This could be due to test technique, since four point bending usually gives higher toughnesses than double torsion tests, and slow creep cracks are probably blunter than indentation cracks. Alternatively, this particular batch of NCX34 might be especially 


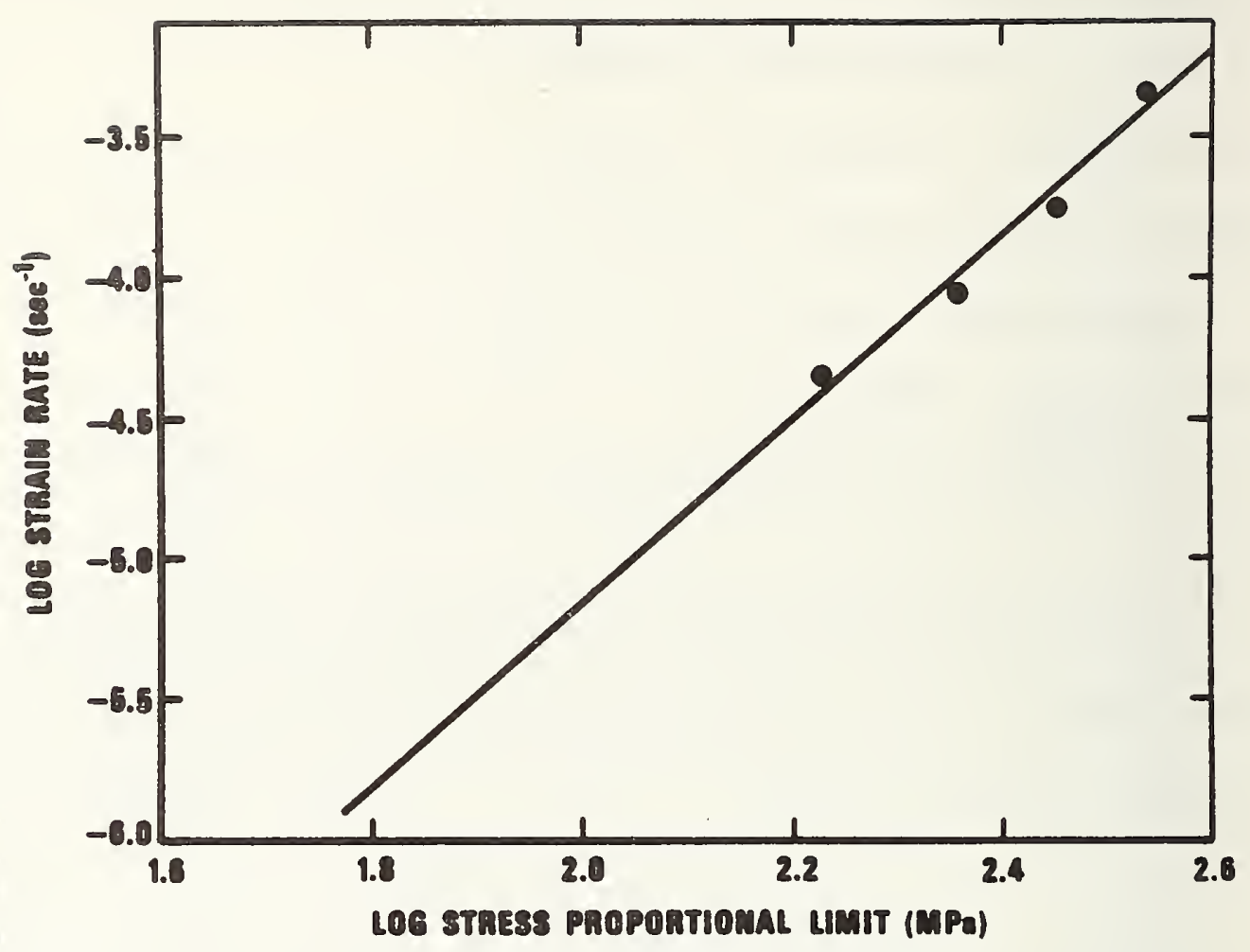

Fig. 6. Proportional Limit Yield Stress as a Function of Strain Rate in $\mathrm{NCX} 34$ at $1400^{\circ} \mathrm{C}$. 
strong as is suggested by other strength studies made on this billet. 14 In any case, regardless of the exact values repcrted here, the trends with loading rate or delay time should represent general trends in hotpressed silicon nitrides.

Fig. 4 shows that there is a strong variation in toughness with displacement rate. This raises a serious question as to the existence of a unique fracture toughness which reflects a material's microstructural resistance to fracture. If there is no unique value, then $\mathrm{K}_{\mathrm{IC}}$ must be measured for each strain rate in question. However, we feel that the time dependent plastic response of this material at $1400^{\circ} \mathrm{C}$ is responsible for lessening the intensification of the stress near the crack tip. Therefore, the $\mathrm{K}_{\mathrm{IC}}$ measured at the highest rate will most nearly approach the purely elastic case and ought to be the correct value for comparison of a material's fracture properties. The average $\mathrm{K}_{I C}$ for four specimens measured at $1.25 \mathrm{~mm} / \mathrm{min}$ (i.e. the fastest rate) and $1400^{\circ} \mathrm{C}$ is $7.9 \pm .6 \mathrm{MPa} \sqrt{\mathrm{m}}$. This value is slightly below the room temperature value in accord with the trond observed in Impact studies on NCI32. While $1.25 \mathrm{~mm} / \mathrm{min}$ is not an impact test, it is very fast for a material with good creep resistance like NCX34. It is Interesting to note that there was no appreciable difference in toughness between pre-cracked specimens and as-slit specimens.

The $\mathrm{K}_{\text {IC }}$ measured at lower rates represents some mixture of a material's fracture and deformation behavior. It is probably the more important engineering quantity to specify since it is the effective toughness that will be observed at a given, low strain rate.

Knowing both $K_{I C}$ for the purely elastic case (rapid fracture with little deformation) and the deformation behavior, allows one to predict the apparent $K_{\text {IC }}$ for the case of fracture preceded by deformation. One of the simplest 
adjustments is to recalculate $\mathrm{K}_{\mathrm{IC}}$ assuming that the crack is longer than the measured crack by an amount equal to the extent of the deformation zone. Such an assumption works well for metals. It may be particularly valid for silicon nitride in which cavitation is a major component in the tensile creep deformation. 12

The radius of the deformation zone may be derived from the stress distribution ahead of the crack tip, i.e.

$$
\sigma=K / \sqrt{2 \pi r}
$$

by inserting the appropriate stress and solving for distance ahead of the crack tip(r):

$$
r_{p l}=\frac{1}{2 \pi} \frac{K_{I C}}{\sigma_{p l}}
$$

Note that this analysis relies on the assumption that the stress field outside of the small plastic zone is described by $K$. The above distance $\left(r_{p l}\right)$ is then added to the crack length used in the highest strain rate measurement of $K_{I C}(a=5.02 \mathrm{~mm}) . K_{I C}$ is then recalculated from Eqn. 1 using the new crack length and the original load at fracture for the high rate $\mathrm{K}_{I C}(471 \mathrm{~N})$. This is the predicted $\mathrm{K}_{\text {IC }}$ corresponding to the strain rate at which o $\sigma_{p l}$ was measured.

To carry this procedure out for the present data, the strain rate was determined from the displacemest rate in a bend test. ${ }^{15}$ The relation used is: 16

$$
\dot{\varepsilon}_{\max }=\frac{6(W-a)}{\left(l_{2}-l_{1}\right)\left(l_{2}+2 l_{1}\right)} \dot{\Delta}
$$

where $\dot{\varepsilon}_{\max }$ is the strain rate in the outer fiber, $\dot{\Delta}$ is the displacement rate, $\ell_{2}$ and $\ell_{1}$ are the major and minor spans, and $(W-a)$ is the ligament width. The assumption is made here that the strain rate at the crack tip 
is equal to the outer flber strain rate in an elastic bar having a width equal to the remaining ligament width. Since most of the bar is deformed elastically, Eqn. 5 seems more appropriate than an equation which assumes a creeping or perfectly plastic material. At longer times than were studied here, however, creep deformation occurs on a scale comparable to the specimen's dimensions and other relations would have to be used. In this regime, however, the validity of measuring $\mathrm{K}_{\mathrm{IC}}$ would also be questionable.

In Table 2, the strain rates at which the tests were carried out are listed in decreasing order in the first column. In the second column, the corresponding yield stresses calculated from Eqn (5) are shown. These yield stresses are then used (Eqn. (4)) to determine the plastic zone size. Finally the corrected $\mathrm{K}_{I C}$ is calculated from the highest rate $\mathrm{K}_{\mathrm{IC}}$ by altering the effective crack length by an amount equal to the extent of the deformation. These values may be compared with the experimentally determined ones in the last column. This comparison is shown graphically in Fig. (7). The agreement between the predicted and experimental toughness is as good as the scatter between the experimental values. The predicted line tends to be below the experimentally determined points. This could be due to the measurement of the creep stress in compression rather than in tension. Creep should occur more readily at lower stresses in tension. This would tend to shift the predicted line upward and give better agreement.

The effect of the deformation or plastic zone on the toughness decreases with time after unloading as shown in Fig. (5). It takes about 1 hour at $1400^{\circ} \mathrm{C}$. to recover fully. The effect can be frozen in by cooling to room temperature under load. This is additional evidence that it is the time dependent deformation which is responsible for increasing the apparent $\mathrm{K}_{\mathrm{IC}}$ by reducing the crack tip stress field intensification. The delay time 


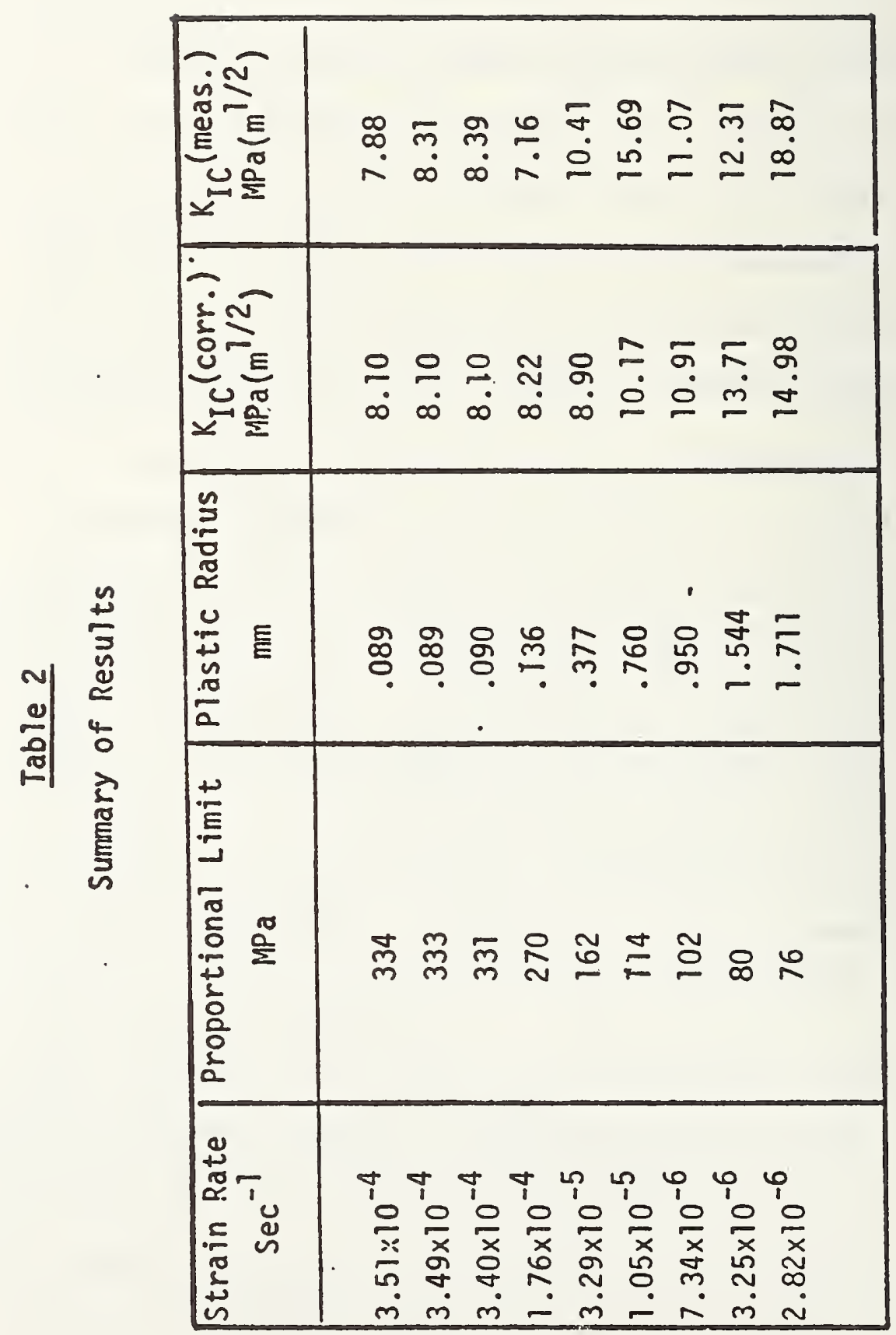




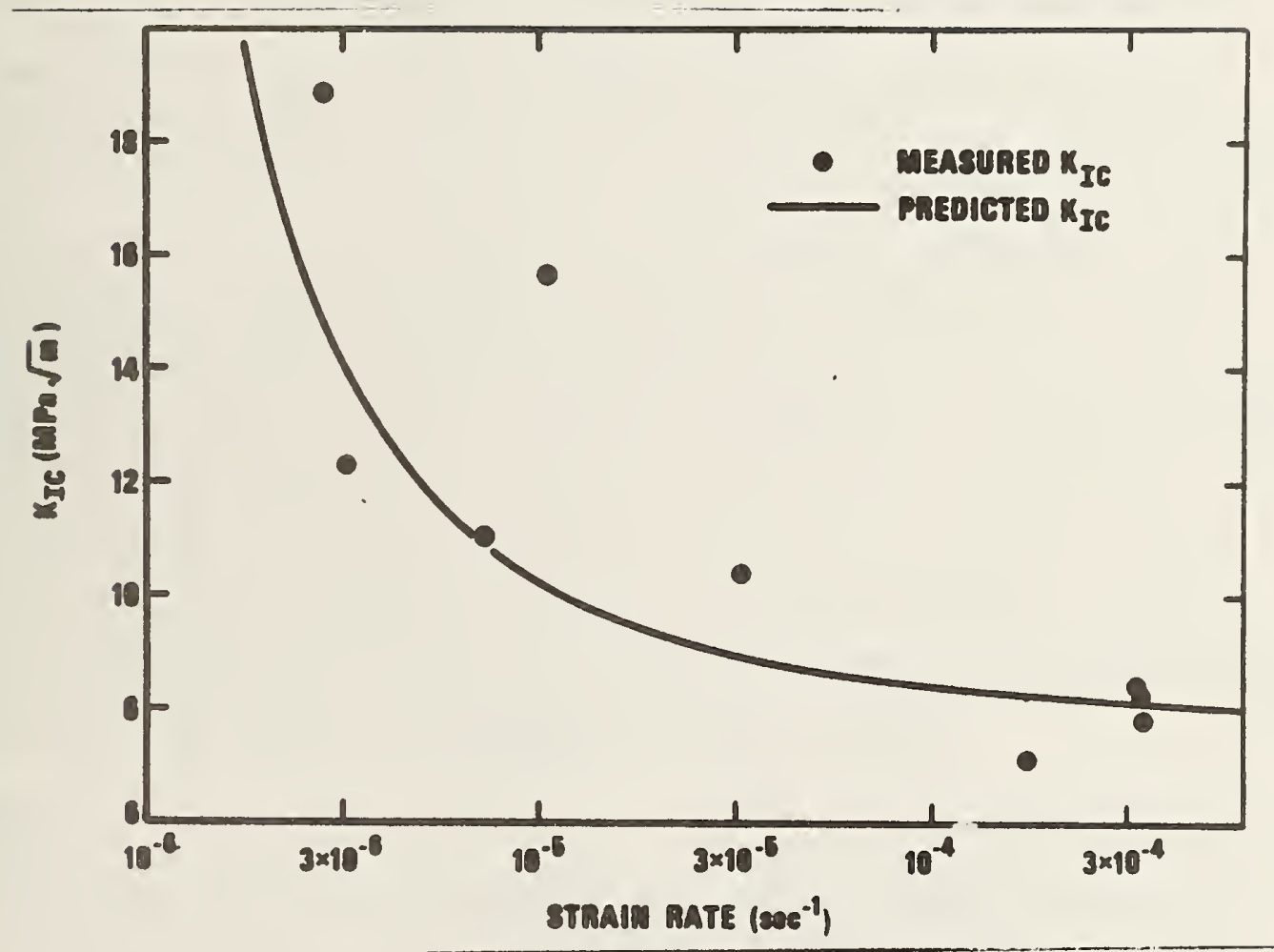

Fig. 7. Measured and Predicted $\mathrm{K}_{\mathrm{IC}}$ as a Function of Crack Tip Strain 

several hours, no appreciable change in fracture properties was noted when they were compared to the specimens that were tested at room temperature or heated and tested immediately. Also, the microstructural instability cannot simultaneously explain the delay time effect and the strain rate effect.

It is important to note that the range of strain rates over which the plastic zone correction is applicable is limited. At very high strain rates, the zone is so small that it makes a negligible correction to the $\mathrm{K}_{\mathrm{IC}}$ and the toughness there should be independent of rate. At very low strain rates, the creep deformation extends throughout the whole.specimen so that the correction would give effective crack lengths equal to or greater than the specimen width. In such a case, $\mathrm{K}_{\mathrm{I}}$ no longer descrioes the crack tip stress field and it might be better to evaluate $J_{I C}$ in order to predict the $\mathrm{K}_{\mathrm{IC}}$ that would be obtained in larger bodies.

5. CONCLUSION

At temperatures where creep becomes an important component in the deformation of silicon nitride, the apparent $\mathrm{K}_{\mathrm{IC}}$ depends on the rate at which the fracture test is carried out. This toughening is due to the relaxation of crack tip stress intensification by high temperature, time dependent plasticity rather than oxidation or microstructural effects. It has been shown here that, when the extent of this deformation is small, its effect on the toughness may be estimated by making a plastic zone correction to the crack length.

Acknowledgments: The authors thank P. L. Land of A1r Force Materials Laboratory, Wright-Patterson $A F B$ and $R$. deWit for helpful advice and useful discussions. 


\section{References}

1. A.G. Evans and S.M. Wiederhorn, J. Mater. Sci. 9 (1974) 270.

2. T.D. Ketcham and R.M. Cannon, Amer. Ceram. Soc. Bul. 58 (1979) 343.

3. M. Srinivasan and R.H. Smoak, Amer. Ceram. Soc. Bul. 58 (1979) 347.

4. D.G. Miller, C.A. Anderson, S.C. Singhal, F.F. Lange, E.S. Diaz, and R. Kossowsky, AMMRC 76-32, ARPA Order No. 1849, Project Code No 1D10, Agency Accession No. OD 4733, December 1976.

5. M.G. Mendiratta, J. Wimmer, and J. Bransky, J. Mater. Sci. 12 (1977) 212.

6. S.T. Gonczy and D.L. Johnson, "Fracture Mechanics of Ceramics, Vol. 13," edite by R. C. Bradt, D.P.H. Hasselman, and F.F. Lange (Plenum Press, New York, 1978) P. 495.

7. J.J. Petrovic and L.A. Jacobson, J. Amer. Ceram. Soc. 59 (1976) 34.

8. S.T. Rolfe and J.M. Barsom, "Fracture and Fatigue Control in Structures; Applications of Fracture Mechanics," (Prentice-Ha11, Englewood Cliffs, N.J., 1977).

9. G.R. Irwin, Appl. Mater. Res. 3 (1964) 65.

10. H. Tada, P.C. Paris, and G.R. Irwin, "The Stress Analysis of Cracks Handbook", (Del Research Corp., Hellertown, PA., 1973).

11. W.F. Brown, Jr. and J. Srawley, "Plane Strain Crack Toughness: Testing of High Strength Metallic Materials", ASTM-STP 410 (Amer. Soc. Testing and Mater., Phila; PA., 1966).

12. F.F. Lange, Met. Trans. (to be published).

13. S.W. Freiman, private communication.

14. N.J. Tighe and S.M. Wiederhorn, Air Force Mater. Lab. Tech. Rpt., AFML-TR-78-83 (1978).

15. P.L. Land, J. Mater. Sci. (to be published).

16. G.W. Hollenberg, G.R. Terwilliger, and R.S. Gordon, J. Amer. Ceram . Soc. 54 (1970) 196.

17. F.F. Lange, S.C. Singhal, and R. C. Kuznicki, J. Amer. Ceram. Soc. 60 (1977) 249. 
BS.114A IREV. 2.78 ,

\begin{tabular}{|c|c|c|c|}
\hline $\begin{array}{l}\text { U.S. DEPT. OF COMM. } \\
\text { BI8LIOGRAPHIC DATAA } \\
\text { SHEET }\end{array}$ & $\begin{array}{l}\text { 1. PUBLICATION OR REPORT NO. } \\
\text { NBSIR } 79-1960 \quad \text { (R) } \quad \text { (DOE) }\end{array}$ & 2.Gov't Accession No. & 3. Reciatent's Áccession No. \\
\hline \multicolumn{3}{|c|}{$\begin{array}{l}\text { 4. TITLE AND SUBTITLE } \\
\text { EFFECT OF STRAIN RATE ON THE FRACTURE TOUGHNESS OF } \\
\text { SILICON NITRIDE AT } 1400^{\circ} \mathrm{C}\end{array}$} & $\begin{array}{l}\text { 5. Publication Date } \\
\text { October } 1980 \\
\text { 6. Performing Organization Code }\end{array}$ \\
\hline \multicolumn{3}{|c|}{$\begin{array}{l}\text { 7. AUTHOR(S) } \\
\text { R. J. Fields, N. J. Tighe, E. R. Fuller, Jr. }\end{array}$} & 8. Performing Organ. Report No. \\
\hline \multicolumn{3}{|c|}{$\begin{array}{l}\text { NATIONAL BUREAU OF STANDARDS } \\
\text { DEPARTMENT OF COMMERCE } \\
\text { WASHINGTON, DC } 20234\end{array}$} & 10. Project/Task/Work Unit No. \\
\hline \multirow{2}{*}{\multicolumn{3}{|c|}{$\begin{array}{l}\text { 12. SPONSORING ORGANIZATION NAME AND COMPLETE ADDRESS (Street, City, State, zIP) } \\
\text { Department of Energy } \\
\text { Washington, D.C. }\end{array}$}} & $\begin{array}{l}\text { 13. Type of Report \& Period Covered } \\
\text { Inter im }\end{array}$ \\
\hline & & & 14. Sponsoring Agency Code \\
\hline
\end{tabular}

15. SUPPLEMENTARY NOTES

Document describes a computer program; SF-185, FIPS Software Summary, is attached.

16. ABSTRACT (A 200-word or less factual summary of most significant information. If document includes a significant bibliography or literature survey, mention it here.)

The critical stress intensity factor for fracture, $K_{I C}$, was measured in $\mathrm{Si}_{3} \mathrm{~N}_{4}$ at $1400^{\circ} \mathrm{C}$ as a function of strain rate. It was found that $\mathrm{K}_{\text {IC }}$ increased with decreasing rates of bending of notched bars. This effect could be approximately predicted using a time dependent plastic zone correction to $\mathrm{K}_{\mathrm{IC}}$.

17. KEY WORDS (six to twelve entries; alphabetical order; capitalize only the first letter of the first key word unless a proper name; separated by semicolons)

Crack growth; creep fracture; high temperature fracture; silicon nitride; strain rate effect; toughness.

18. AVAILABILITY Xn Unimited

For Official Distribution. Do Not Release to NTIS

Order From Sup. of Doc., U.S. Government Printing Office, Washington, DC 20402, SD Stock No. SNO03-003-

X Crder From National Technical Information Service (NTIS), Springfield, VA. 22161

\begin{tabular}{|l|c|}
\hline $\begin{array}{l}\text { 19. SECURITY CLASS } \\
\text { (THIS REPORT) }\end{array}$ & $\begin{array}{c}\text { 21. NO. OF } \\
\text { PR!NTED PAGES }\end{array}$ \\
UNCLASSIFIED & 23 \\
\hline $\begin{array}{l}\text { 20. SECURITY CLASS } \\
\text { (THIS PAGE) }\end{array}$ & 22. PrICE \\
UNCLASSIFIED & $\$ 5.00$ \\
\hline
\end{tabular}



FRACTURE STRENGTH AND THE WEIBULL DISTRIBUTION OF $\beta$-SIALON

Kazuo Kobayashi, Seiki Umebayashi, and Kazushi Kishi

Goverment Industrial Research Institute, Kyushu

Shuku-machi, Tosu-shi 841

Nancy J. Tighe and Richard J. Fields

National Bureau of Standards

Washington, DC 20234 



\title{
$\beta$-サイアロン焼結体の破買強度とワイブル分布
}

小林和夫・梅林正気・岸 和司・Nancy J. Tighe*・Richard J. Fields*

(九州工業技術試験所

* National Bureau of Standards

加圧燒結 $\beta$-サイアロン $\left(\mathrm{Si}_{6} \mathrm{Al}_{1} \mathrm{O}_{1} \mathrm{~N}_{2}\right)$ の室温, $1200^{\circ} \mathrm{C}$ 及び $1400^{\circ} \mathrm{C}$ の 4 点曲げ強度及びワイブル 分布を測定した. 加圧燒結 $\beta$-サイアロンは $\mathrm{SiO}_{2}, \mathrm{Al}$ 及び $\mathrm{Si}$ 粉末を $\mathrm{N}_{2}$ 中で焼成することにより 作成したものである. 見掛け比重は約 3.14 であった。加圧燒結試料は $\mathrm{X}$ 線回折からは結晶相として $\beta$-サイアロン単相であるが, 走查型電子顕微鏡観察からガラス質境界相が認められた.室温における 強度の最高值は $450 \mathrm{MPa}$ であり, ワイブル係数, $m$ は 8.4 であった。 $1200^{\circ} \mathrm{C}$ では, 最高強度は変 わらないが $m$ 值は 3.1 に低下した. $m$ 值の減少は表面の所々に少数出現したピットのためと考え

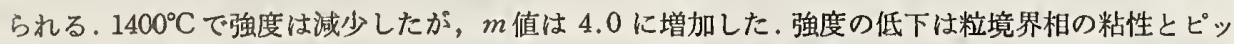
卜生成の增大による。表面全体に出現したピットと表面酸化層が表面を均質化し，ワイブル値， $m$ を $1400^{\circ} \mathrm{C}$ で增加させたものと思われる，4点曲げノッチドビームテストによる破壊じん性值， $K_{1 \mathrm{c}}$ は 約3.2 $\mathrm{MPa} \sqrt{\mathrm{m}}$ であり, 宝温から $1400^{\circ} \mathrm{C}$ までほとんど一定であった。（1981 年 1 月 6 日受付）

\section{Fracture Strength and the Weibull Distribution of $\beta$-sialon}

\author{
Kazuo KOBAYASHI, Seiki UMEBAYASHI, Kazushi KISHI \\ Nancy J. TIGHE* and Richard J. FIELDS* \\ ( Government Industrial Research Institute, Kyushu \\ Shuku-machi, Tosu-shi 841 \\ * National Bureau of Standards, Washington D.C. 20234, U.S.A.)
}

4-point bending strength and the Weibull distribution were measured for hot-pressed $\beta$ - 
sialon $\left(\mathrm{Si}_{5} \mathrm{Al}_{1} \mathrm{O}_{1} \mathrm{~N}_{7}\right)$ at room temperature, $1200^{\circ} \mathrm{C}$ and $1400^{\circ} \mathrm{C}$ in air.

The hot-pressed $\beta$-sialon was fabricated from $\mathrm{SiO}_{2}, \mathrm{Al}$ and $\mathrm{Si}$ powders in $\mathrm{N}_{2}$. The apparent specific gravity was about 3.14. The hot-pressed sample was consisted of single $\beta$-sialon as a crystalline phase by $\mathrm{X}$-ray analysis, but glassy grain boundary phase was detected by SEM observation.

The room temperature strength was about $450 \mathrm{MPa}$ as the maximum value and the Weibull parameter, $m$, was 8.4 . The $m$ value decreased to 3.1 at $1200^{\circ} \mathrm{C}$ showing almost same maximum strength at room temperature. Decrease of $m$ value was considered to be due to the formation of a few local pits which appeared on the surface. At $1400^{\circ} \mathrm{C}$ the strength decreased, while the $m$ value increased to 4.0 . This strength degradation was due to viscous grain boundary phase and increase of pit formation. Appearance of pits on all over the surface and formation of oxidized layer seemed to form relatively homogeneous surface and increased Weibull parameter, $m$, at $1400^{\circ} \mathrm{C}$. The fracture toughness, $K_{\mathrm{lc}}$, measured by 4-point notched bend test was almost constant value of about $3.2 \mathrm{MPa} \sqrt{\mathrm{m}}$ from room tem. perature to $1500^{\circ} \mathrm{C}$.

[Received January 6, 1981]

Key-words : $\beta$-sialon, High temperature strength, Weibull distribution, Fracture toughness

\section{1. 緒旁}

$\mathrm{SiO}_{2}, \mathrm{Al}$ 及び $\mathrm{Si}$ を出発原料とし，加压焼結により作 成した $\beta$-サイアロン $\left(\mathrm{Si}_{6-z} \mathrm{Al}_{z} \mathrm{O}_{z} \mathrm{~N}_{8-z}\right)$ の $z=1$ 組成 の焼結体について, 宝温, $1200^{\circ} \mathrm{C}$ 及び $1400^{\circ} \mathrm{C}$ の空気 ふル䎴気中における 4 点曲げ強度を測定し，ワイブルプ ロットを行いワイブル係数 $m$ を, 生た， ノッチドビー ム法による破壊じん性值 $K_{\mathrm{lc}}$ を求ぬた。

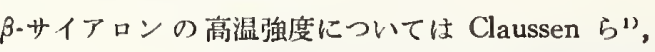
Gauckler ら², 三友ら ${ }^{8)}$ あるいは Dutta" の報告があ る. Claussen らは $\mathrm{Si}_{3} \mathrm{~N}_{4}$ と $\mathrm{Al}_{2} \mathrm{O}_{3}$ を沖発原料として, $1800^{\circ} \mathrm{C}$ で加圧焼結し得られた $\beta$-サイアロン烍結体（ $\beta$ サイアロン以外に少量のX相及び $\alpha-\mathrm{Si}_{3} \mathrm{~N}_{4}$ が存在してい る)について 3 点曲げ強度を測定し, 室温で $580 \mathrm{MN} / \mathrm{m}^{2}$, $1450^{\circ} \mathrm{C}$ で $260 \mathrm{MN} / \mathrm{m}^{2}$ の值を得ている. そして, $\mathrm{MgO}$ 添加 $\mathrm{Si}_{3} \mathrm{~N}_{4}$ 加圧焼結体よりも高温强度がすぐれており, それは $\mathrm{MgO}$ 添加により生成した $\mathrm{Mg}$ ケイ酸塩の境界 相より， $\beta$-サイアロンにおけるX相からなる境界相の方 が高温强度にすぐれているためであると指摘している。

また, Gauckler らは $z=1$ 組成に相当する加圧煋結 $\beta$-サイアロンの曲げ強度を求め, 室温で $40 \sim 50 \mathrm{~kg} / \mathrm{mm}^{2}$, $1400^{\circ} \mathrm{C}$ で約 $30 \mathrm{~kg} / \mathrm{mm}^{2}$ の值を得ている. Dutta は $\mathrm{Si}_{3} \mathrm{~N}_{4}, \mathrm{AlN}$ と $\mathrm{Al}_{2} \mathrm{O}_{8}$ を原料とし, これに少量の $\mathrm{Y}_{2} \mathrm{O}_{3}$ を添加して得た常圧焼結 $\beta$-サイアロンについて $1000^{\circ} \mathrm{C}$ で $483 \mathrm{MPa}, 1380^{\circ} \mathrm{C}$ で $228 \mathrm{MPa}$ の值を得ており高温 における強度低下は境咽相の軟化によると報告してい る. また, 三友らは同じく $\mathrm{Si}_{3} \mathrm{~N}_{4}, \mathrm{Al}_{2} \mathrm{O}_{3}$ 及び $\mathrm{AlN}$ を 出発原料とし、ボールミル中の $\mathrm{Al}_{2} \mathrm{O}_{3}$ 混入量を補正し た加圧焼結 $\beta$-サイアロン, $\mathrm{Si}_{8} \mathrm{Al}_{2} \mathrm{O}_{2} \mathrm{~N}_{6}$ ( $z=2$ 組成),の 室温強度は $44 \mathrm{~kg} / \mathrm{mm}^{2}$ であり, $1300^{\circ} \mathrm{C}$ まで強度の低下 はみられず, $1400^{\circ} \mathrm{C}$ でわずかに低下して $41 \mathrm{~kg} / \mathrm{mm}^{2}$ の 傎を示したことを報告し, $\beta$-サイアロンの高温強度の挙 動はX相の存在量によることを述べている.

本報告は， $\beta$-サイアロン加圧焙結体の高温强度の測定
とともに, 各温度における強度と破壊確率の関係を求 め, 强度のバラッキの原因となった理由について考察し たものである.

\section{2. 寒験方法}

\section{1 㖑料調 製}

出発原料及び試料作成法は既報ら”に述べた手順にし たがった. すなわち，出発原料は: ケイ石粉末（粒度 $<1 \mathrm{~mm} \phi, \mathrm{SiO}_{2}: 99.9, \mathrm{Al}_{2} \mathrm{O}_{3}: 0.018 \mathrm{wt} \%, \mathrm{Fe}_{2} \mathrm{O}_{8}: 31$ ppm, $\mathrm{Na}_{2} \mathrm{O}+\mathrm{K}_{2} \mathrm{O}: 32 \mathrm{ppm}$ ), Al 粉末 (粒度 $<200$ × ッシュ, Al : 99.75, $\mathrm{Si}:<0.07, \mathrm{Fe}: 0.16, \mathrm{Cu}: 0.05$ $\mathrm{wt} \%$ ) 及び Si 粉末（粒度 $<200$ メッシュ, Fe : 0.74, $\mathrm{Cu}: 0.01, \mathrm{Ni}: 0.03 \mathrm{wt} \%)$ である. これらの混合粉末 が空化により $\beta$-サイアロンの組成, $\mathrm{Si}_{6-z} \mathrm{Al}_{z} \mathrm{O}_{z} \mathrm{~N}_{8-z}$ の $z=1$ 組成になるように, $\mathrm{SiO}_{2}: \mathrm{Al}: \mathrm{Si}=16.6: 13.6:$ 69.8 の割合に取り, アルミナ製ポールミルで 20 時間 混合・粉砕した. この混合粉砕は $n$-ブタノールを使用 し, 湿式で行った. 混合 ・ 粉砕後の原料粉末の粒径は $15 \mu \mathrm{m}$ 以下となり, 粉砕容器からの アルミナの混入に よる $\mathrm{Al}$ の増加量は, $\mathrm{Al}$ が初期の $13.6 \mathrm{wt} \%$ から 13.8 wt\% となったので, 0.2 wt\% であった.

次いで, この混合粉末を $400 \mathrm{~kg} / \mathrm{cm}^{2}$ の压力で $65 \mathrm{~mm}$ 角の圧粉体にに成形, この成形体を $\mathrm{N}_{8}$ 気流中で $1400^{\circ} \mathrm{C}$ まで帠温し, $1400^{\circ} \mathrm{C}$ で 10 時間保持して至化処理した. 次に, この窒化焼成体の周辺部を切断して $60 \mathrm{~mm}$ 角と し, 同形状の黒鉛ダイス内に入れ, $250 \mathrm{~kg} / \mathrm{cm}^{2}$ の加圧下 で $1800^{\circ} \mathrm{C}$ まで加圧焼結した， $1800^{\circ} \mathrm{C}$ における保持時 間は 1 時間とした.

\section{2 曲げ試験}

上記の条件による加圧焼結により得られた $60 \times 60 \times 5$ $\mathrm{mm}$ の焼結体 6 ブロックを, それぞれ周辺部及び表層部 分を研削により取り除き, $55 \times 55 \times 4 \mathrm{~mm}$ の寸法とした.

この寸法の焼結体より $55 \times 4 \times 3 \mathrm{~mm}$ の試片を数個ず 
552

Yogyo-Kyokai-Shi 89 [10] 1981

つ切り出し，400 番のダイヤモンドホイールで平面研削 後, 4 点曲げ試験に供した.この場合, 1 ブロック焼結体 より切り出した試片をそれぞれ，室温， $1200^{\circ} \mathrm{C}, 1400^{\circ} \mathrm{C}$ 試験用に分けて用い，全体で各温度の測定試験片はそれ ぞれ 12 試片となった.

4 点曲げ用治具は反応焼結 $\mathrm{SiC}$ 製であり，スパン距離 は上部 $10 \mathrm{~mm}$ ，下部 $40 \mathrm{~mm}$ である. 試験片は治具に正 確にセットした後, 室温, あるいは $1200^{\circ} \mathrm{C}$ 及び $1400^{\circ} \mathrm{C}$ まで空気中で界温し，30 分間所定温度で保持した後， クロスヘッドスピード $0.254 \mathrm{~cm} / \mathrm{min}$ の条件で試片を破 断し, 曲げ強度を求めた。

\section{3 ワイブル分布及び係数 $m$ 犆の測定}

各温度における曲げ強度と測定個数 $N$ より，经プロ ット法によりワイブル分布及び係数 $m$ を求めた、計算 の手順は次のとおりである.

ワイブル分布関数における破壊礁率 $P$ は次式であら わされる。

$$
P=1-\exp \left[-K V\left(\frac{\sigma-\sigma_{\mathrm{u}}}{\sigma_{0}}\right)^{m}\right]
$$

変形して

$$
\frac{1}{1-P}=e^{K V}\left(\frac{\sigma^{-\sigma_{u}}}{\sigma_{0}}\right)^{m}
$$

同じく

$$
\ln \ln \left(\frac{1}{1-P}\right)=m \ln \left(\sigma--\sigma_{\mathrm{u}}\right)+\ln \left(\frac{K V}{\sigma_{0}{ }^{m}}\right)
$$

ここで，m:りイブル係数， $\sigma:$ 破壞強度， $\sigma_{\mathrm{u}}$ : これ以 トでは破壊が生じないと想される強度値，V：荷車卜 にある材料の体積， $K$ : 荷重の形式による定数， $\sigma_{0}:$ ワ イプルパラメーターの一つで 尺度のパラメーター（他 は $m$ : 形のパラメーター, $\sigma_{\mathrm{u}}$ : 位置のパラメーター) $\ln \ln \left(\frac{1}{1-P}\right)$ を縦座標, $\ln \left(\sigma-\sigma_{\mathrm{u}}\right)$ を横座標にとれば, （3）式は淔線となり，ワイブル係数 $m$ はそのこう配で 読みとれる. $\ln \left(\frac{K V}{\sigma_{0}{ }^{m}}\right)$ は縦軸を切る値となる、

強度を大きい做から順に並べて， $n$ 番目の蚛度がもつ 破填確率? $P_{n}$ は

$$
P_{n}=\frac{n}{N+1}
$$

で表わすことができる、従って，(3) 式は

$$
\ln \ln \left(\frac{N+1}{N+1-n}\right)=m \ln \left(\sigma-\sigma_{\mathrm{u}}\right)+\ln \left(\frac{K V}{\sigma_{0}^{m}}\right)
$$

となる。

本实験における各温度の測定数は $N=12$ であり， $\sigma u$ はゼロとお゙いた. 従って, $\ln \ln \left(\frac{N+1-n}{N+1}\right)$ と $\ln \sigma$ の 関係を罒にプロットし，最小二.乘法に上り消線を引き， そのこう配よりりイブル保数 $m$ 值を計算した。

2.4 破罗じん性值 $\boldsymbol{K}_{1}$ ：の測定

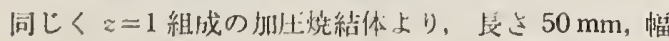

K. KOBAYASHI et al

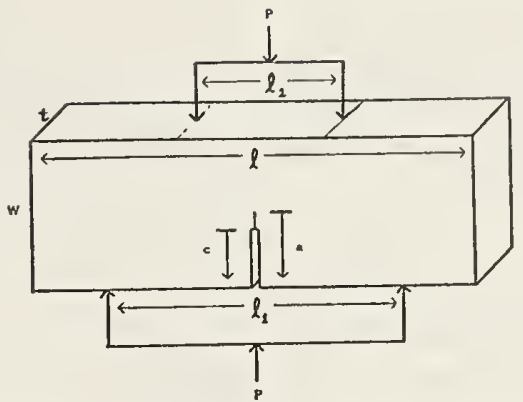

Fig. 1. Schematic of four-point notched bend test.

$4.5 \mathrm{~mm}$, 厚み $10 \mathrm{~mm}$ の試片を切り出し, 平面研削後, $0.5 \mathrm{~mm}$ 幅のダイヤモンドホイールで梁さ $1.5 \mathrm{~mm}$ のス リットを切り込んだ.この形状の試片を用い，4点曲げ ノッチドビーム法により，曲げ試験を行い，次式 り， $K_{1 \mathrm{c}}$ を求めた.

$K_{1 \mathrm{c}}=\left\{3 P\left(l_{1}-l_{2}\right) / t-w^{2}\right\} \sqrt{\pi a} F(a / w)$

$F(a / w)=\sqrt{2 w / \pi a \cdot \tan (\pi a / 2 w)}$

- $\left\{0.923+0.199[1-\sin (\pi a / 2 w)]^{4} / \cos (\pi a / 2 w)\right\}$

ここで, $P:$ 破断荷重, $l_{1}, l_{2}: 4$ 点曲げにおける長短 支点間距離, $t$ : 試片憬み, $W$ : 試片幅, $c$ : スリット切 り込み深さ， $a$ : 試片の破断面から求めたクラック長さ である. 図 1 にノッチドビーム試片のモデルを示す

\section{5 焼結体の組織及ひ破断面の観察}

烧絬体の組織及び破断面は走査型電子瀕微鏡 (SEM) により観察した，試料表面をエッチングする場合には， 硝酸とフッ酸の $70^{\circ} \mathrm{C}$ 混合溶液を用いた.

\section{3. 結果と考察}

加圧焼結により得られた $\beta$-サイアロン焼結体の見掛 け比重はいずれも 3.14 前後であり，X線回折により検 出された結晶相は $\beta$-サイアロンのみであった。 X 線回 折より求めた格子定数は， $a_{0}=7.634 \AA, c_{0}=2.930 \AA$ で あり，ほぼ $\mathrm{Si}_{6-z} \mathrm{Al}_{z} \mathrm{O}_{z} \mathrm{~N}_{8-z}$ で $z=1$ 組成になっている

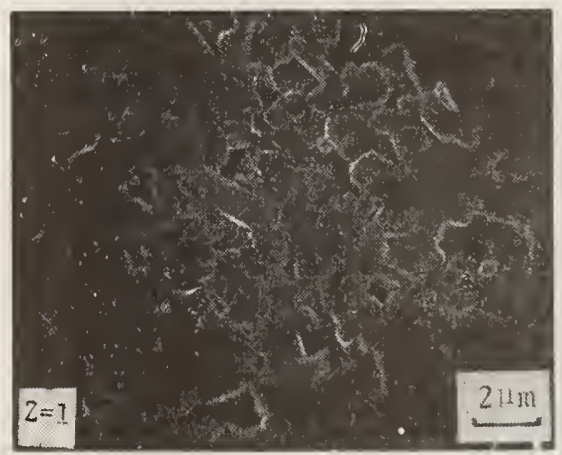

Fig. 2. Microstructure of hot-pressed $\beta$-sialon $\left(\mathrm{Si}_{6-z} \mathrm{Al}_{z} \mathrm{O}_{2} \mathrm{~N}_{\mathrm{8}-2}, z=\mathrm{J}\right.$ ) used in this experiment after polishing and ckling. 
ことが垫めら机た。

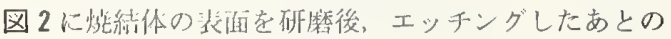
組織少真を示す。エッチング後は料隐界が解明となり，

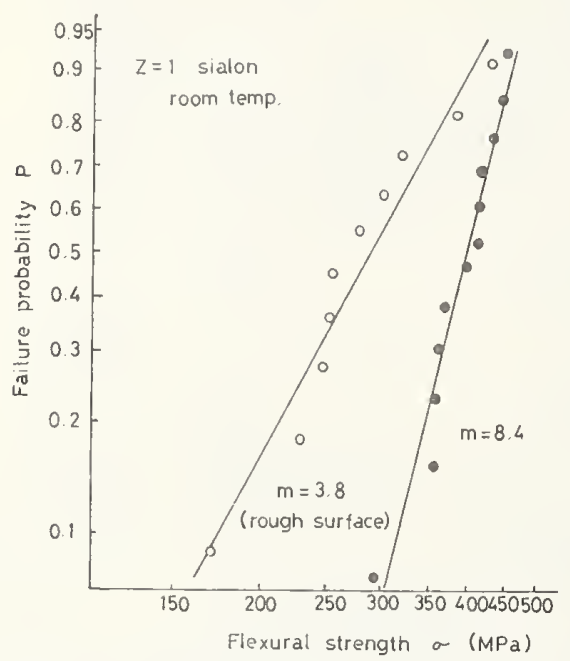

Fig. 3. Weibull distribution curves between failure probability and flexural strength for $\beta$-sialons will tough surface $(O)$ and well-polishedsurface
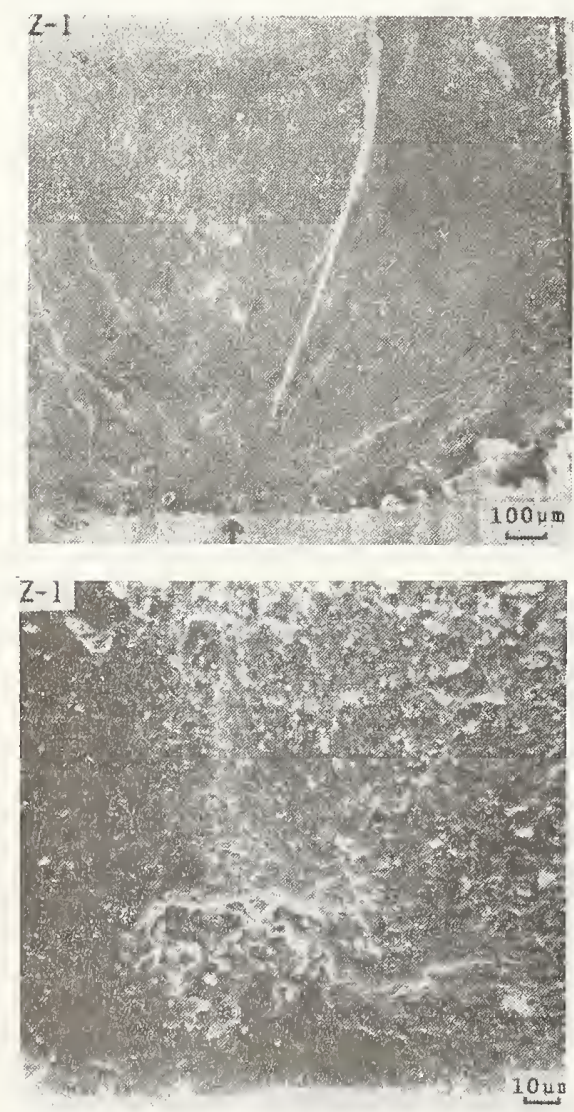

Fig. 4. Pore at lracture origin at room temperature
ところどころにエッチング前には御察できなかった気孔 が生じているところから，ガラス相の存在していること が推起される。粒子径は 1〜2 $2 \mu \mathrm{m}$ 前後である.

図 3 に熴結体 6 ブロック上り，それぞれ切り出した各

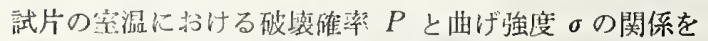
示す。こう配のゆるやかな消線は研磨不十分で試片エッ ジ部分に加工傷の多くある試片について测定したもので あり、こう配の急な植線は 400 番平面研削した試片につ いて測走したものである. いずれも最高值は $450 \mathrm{MPa}$ 前後であるが, 粗な表面で加工傷のある試片の場合は值 がバラッキ，最低值が $170 \mathrm{MPa}$ 前後まで低下し，ワイ ブル係数 $m$ は 3.8 の值であった. 一方, 400 番で研磨 した試片は $m=8.4$ の值を示した. 削者の破断面を観察 寸ると表面の加「傷よりクラックが発生している場合が 多かった。後者の場命は, 加工傷による場合もあるが, 図 4 に示すように表面近くに存在する気孔からクラック が発生している場合が多かった。このように，試片表面

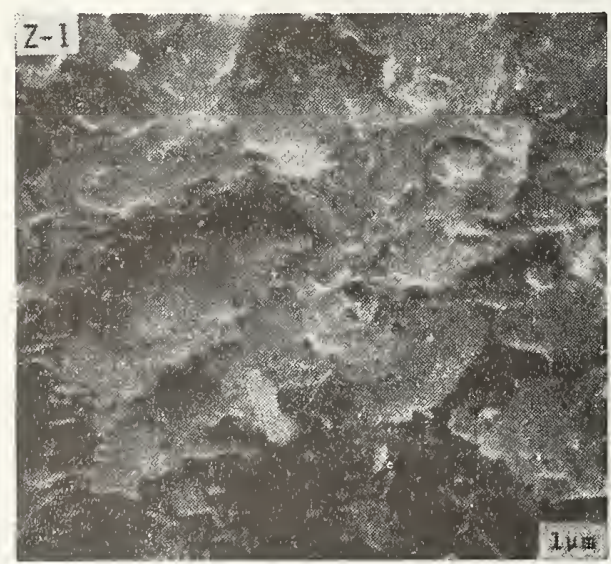

Fig. 5. Fracture surface at room temperature.

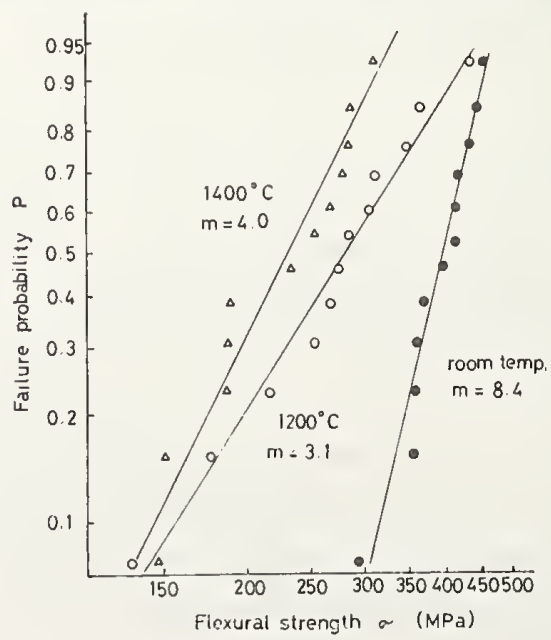

Fig. 6. Weibull distribution curves between failure probability and flexural strength for $\beta$ sialon at room temperature, $1200^{\circ} \mathrm{C}$ and $1400^{\circ} \mathrm{C}$. 
554 Yogyo-Kyokai-Shi $89[10] 1981$

の加工傷の存在によりワイブル係数 $m$ は大きく変わる ことが分る，打工伤をできるだけ少なくすること，㮱結 体内部に生成する気孔をできるだけ少なくすることが $m$ 值の增大に重妿である。空温におお省破断面は图 5 に示

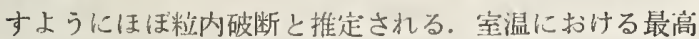
値の約 $450 \mathrm{MPa}$ の值は, Claussen ら”, Gauckler ら²), 三友ら”や Duta" か $\beta$-サイアロン焼結体について求め た佰とほぼ同しである。

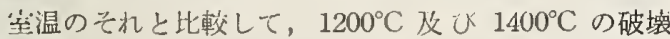
確率 $\Gamma$ 上曲け强度 $\sigma$ の関係を 图 6 に示す. $1200^{\circ} \mathrm{C}$ の 比け强度の最高做は宝温のてれとほぼ変わらないが，強 度低下を交す陚片か多くなり，ハラッキが生し， $m=3.1$ の值を示した， $1400^{\circ} \mathrm{C}$ になる強度の平均值は小さく なるが、ものハラッキは少なくなり， $m=4.0$ となった。 $1200^{\circ} \mathrm{C}$ 処理試片表面を SEM により観察すると图 7 に 示すように，表面に径 1 〜 $3 \mathrm{~m}$ 程度のピットがところ どころに生成している。 また，酸化被膜の生成も認めら れる.このピットの点在の分布状態が武片によって異な り，ワイブル係数 $m$ 值が低下したものと考えられる. 図8に $1400^{\circ} \mathrm{C}$ の試料表面を図9にその破断面を示す。 $1400^{\circ} \mathrm{C}$ 処理試片表面にはピットが全面に多数発生し, しかも均一に分兏している，また，酸化被膜の生成も著 しい，試片内部においても溶融状態がおこり，気泡が生 成しかかっている形跡が認められる。图 10 に $1400^{\circ} \mathrm{C}$

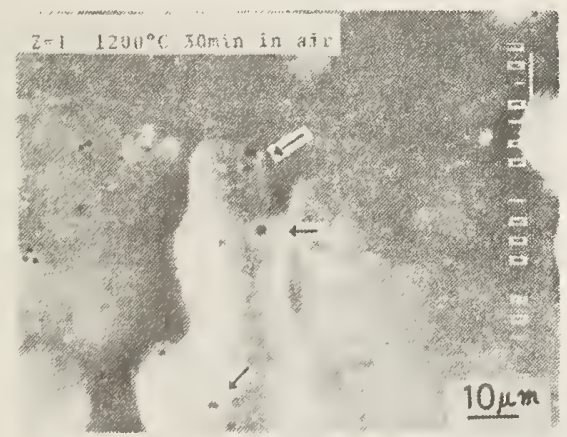

Fig. 7. A few local pits formation (arrows) appeared on the surface at $1200^{\circ} \mathrm{C}$.

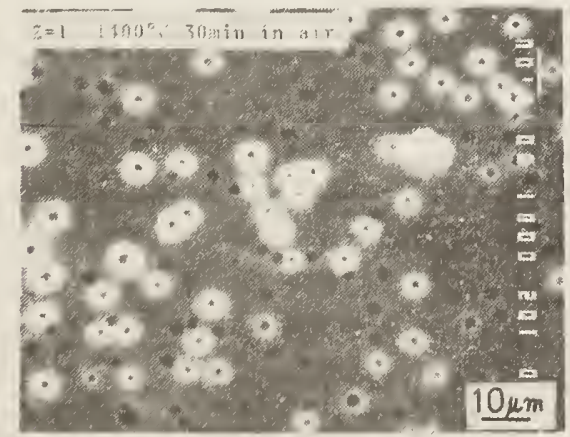

Fig. 8. Appcarance of pits formed on the surface at $1.100^{\circ} \mathrm{C}^{\circ}$
K. KOBAYASHI et al

試片破断面のエッチングき 真を示すが，写具から分るよ うに $1400^{\circ} \mathrm{C}$ の埸合は明らかに粒界破断である。このこ とから， $1400^{\circ} \mathrm{C}$ では粒哭ガラス相の軟化とピットの多 数生成を伴う酸化被膜による表面の一様化が曲げ強度を 全体に低下させ，また，強度のハラッキを少なくして $m$ 值を逆に大きくしたものと考えられる.

これら $\beta$-サイアロン恠結体の高温強度值及びワイプ ル係数值を向上させるためには，粒子境界相の高温特性 を向上させること，あるいは，粒界ガラス相の存在しな いサイアロン焼結体の製造を目指す必要がある.

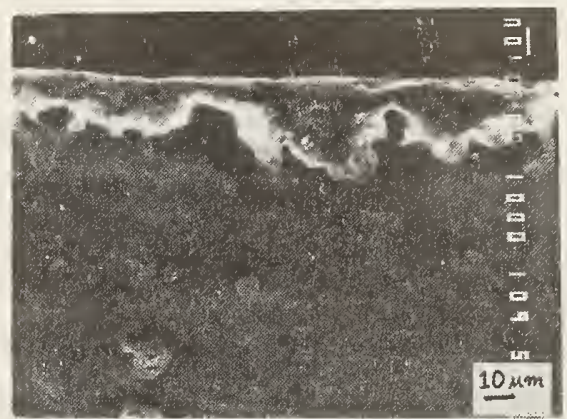

Fig. 9. Fracture surface at $1400^{\circ} \mathrm{C}$.

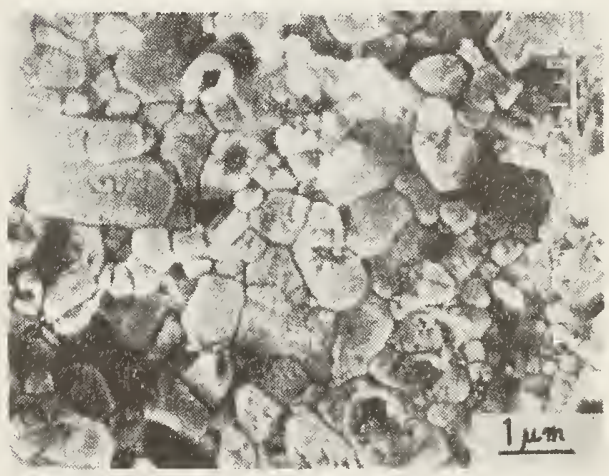

Fig. 10. The fractured surface at $1400^{\circ} \mathrm{C}$ after etching.

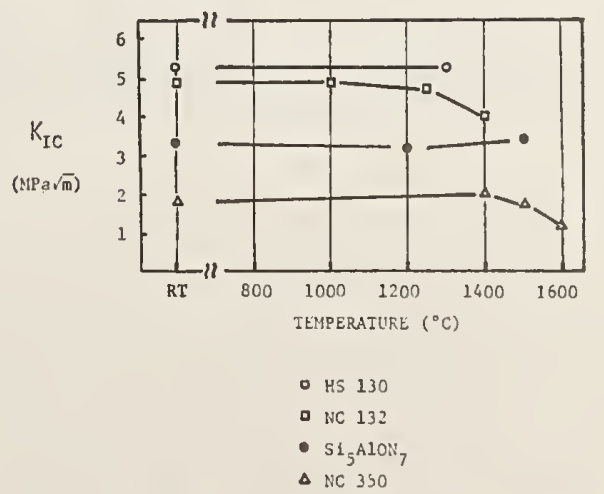

Fig. 11. Fracture toughness, $K_{1 c}$, of $\beta$-sialon $\left(\mathrm{Si}_{5} \mathrm{Al}_{1} \mathrm{O}_{1} \mathrm{~N}_{7}\right)$ and those of hot-pressed $\mathrm{Si}_{3} \mathrm{~N}_{4}$ (HS 130, NC 132) and reaction bonded $\mathrm{Si}_{3} \mathrm{~N}_{4}$ (NC 350) as a function of temperature. 
小牧健男洁か

破壊しん性值 $K_{1 \mathrm{c}}$ の室温から $1500^{\circ} \mathrm{C}$ までの值の変化 を空化ケイ素加圧燒結体 (HS 130,NC 132) 及び反応焠 結体（NC 350）のそれらと比較して図11に示す. サイ アロン焙結体は約 3.2 の值であり, HS 130 及び NC 132 より低く，NC350 より高い。 また，高温での変化が少 ないのが特徴的である. $K_{1 \mathrm{c}}$ の值については, すでに Claussen ら"が $\mathrm{Si}_{8} \mathrm{~N}_{4}$ と $\mathrm{Al}_{2} \mathrm{O}_{8}$ より作った $\beta$ ・サイアロ ン狫結体 (X相， $\alpha-\mathrm{Si}_{8} \mathrm{~N}_{4}$ を含む）が $1200^{\circ} \mathrm{C}$ まで約 $4.2,1200^{\circ} \mathrm{C}$ 以上でやや低下寸ること，これに $\mathrm{ZrO}_{2}$ を 添加して作った $\beta$-サイアロンは約 5.2 で $1500^{\circ} \mathrm{C}$ 付近 までほぼ一定の值を示したことを報告しているが，本実 臨の值はそれらより低いものであった。

\section{4. 枌括}

$\beta$-サイアロン $\left(\mathrm{Si}_{0-g} \mathrm{Al}_{z} \mathrm{O}_{g} \mathrm{~N}_{6-\Perp}\right)$ の $z=1$ 組成の 6 ブ ロックの焼結体について切り出した試片について, それ

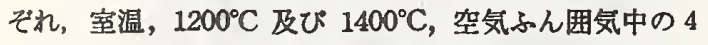
点曲げ強度を測定し，ワイブルプロットを行いワイブル 係数, $m$ 值を求めた結果,

1）室温における曲げ强度の最高値は約 $450 \mathrm{MPa}$ で あり、ワイプル係数, $m=8.4$ であった. 破壊は粓内破 断であった. ワイブル係数， $m$ 㹥試片表面の加工傷の 存在により大きく変動する
窵業協会誌 89 [10］ 1981555

2) $1200^{\circ} \mathrm{C}$ では曲げ強度の最高値は約 $450 \mathrm{MPa}$ を示 したが、ワイブル係数， $m$ は 3.1 と室温の值より低下 した.これは表面に発生したピットの分布状態が試片に よって異なり，強度に影響を及ぼしたものと考えられ る.

3） $1400^{\circ} \mathrm{C}$ では 全体に強度が低下したが，ワイブル 係数， $m$ は 4.0 と $1200^{\circ} \mathrm{C}$ に比べ増大した. 強度の低 下は粒界ガラス相の軟化により， $m$ の増加は表面に一様 に発生したピットと酸化被膜が試片表面を均質化させた ためと推定される.

4）破壊じん性值， $K_{1 \mathrm{c}}$ は約 $3.2 \mathrm{MPa} \sqrt{\mathrm{m}}$ であり， 室温から $1500^{\circ} \mathrm{C}$ までほほ一定であった。

\section{文献}

1) N. Claussen and C.P. Lahmann, Powder Metallurgy International, 7, 133 (1975).

2) L.J. Gauckler, S. Prietzel, G. Bodemer and G. Petzow "Nitrogen Ceramics" Edited by F.L. Riley 529 (1977).

3）三交 護, 長谷川安利, 板東義雄, 渡辺昭辉, 鈴木弘茂, 嘿協, 88, 298 (1980).

4) S. Dutta, Am. Ceram. Soc. Bull., 59, 623 (1980).

5）梅林正気, 小林和夫, 片岡良平, 窵協, 88, 469 (1980).

6) H. Tada, P.C. Paris and G.R. Irwin, "The Stress Analysis of Crack Hand Book" Del Reseach Corp., Hellertown, PA. (1973). 
A PROBABLISTIC FRAMEWORK FOR STRUCTURAL DESIGN

Sheldon M. Wiederhorn

National Bureau of Standards

Washington, DC 20234

To be published in:

Fracture Mechanics of Ceramics, Vol. 5 \& 6

R.C. Bradt, A.G. Evans, D.P.H. Hasselman, and F.F. Lange, eds. Plenum Publishing Corporation, 1982. 



\section{A PROBABILISTIC FRAMEWORK FOR STRUCTURAL DESIGN}

Sheldon M. Wiederhorn

National Bureau of Standards

Washington, D.C. 20234

\section{ABSTRACT}

Recent experiments on structural ceramics at elevated temperatures suggest that time dependent processes such as creep crack growth, cavitation and pit formation have an important influence on the long term reliability of these materials. Since these processes are inherently stochastic, fracture mechanics based theories of structural reliability are not as useful at elevated temperatures as they are at low temperatures. In this paper, an alternative approach to structural design at elevated temperatures is recommended. Although, the approach is probabilistic in nature and suggests the use of probability density functions to describe the time evolution of strength, concepts of fracture mechanics can be factored into the approach. The probabilistic concepts of strength presented here are used for the construction of strength degradation maps, which relates strength, failure time and failure probability on a single diagram. These maps provide a general picture of the failure behavior of a ceramic material and can be used to establish engineering loads and temperatures that are consistent with material behavior.

\section{INTRODUCTION}

Modern structural ceramics are used in a wide range of applications in which thermal, mechanical and chemical loading results in a gradual decay of the strength of these materials. At room temperature the decay in strength is due primarily to subcritical crack growth which initiates from preexisting cracks or flaws that are normally present in ceramic materials. At elevated temperatures the decay in strength is determined by high temperature physical and chemical processes that alter flaw populations and modes of 
failure of these materials. Although materials scientists are generally aware of the processes that determine long term susceptibility to strength degradation, the engineering techniques that have been used to address strength degradation have been limited either to empirically developed safety factors, or to fracturemechanics-based crack growth theories. Although both of these approaches are of value for the prediction of structural reliability, recent experience on experimental heat engines and heat exchangers suggest that alternate procedures may be needed to assure structural reliability in certain applications.

The use of safety factors in design requires extensive practical familiarity with both the design concept and the material used for the design. Safety factors are commonly used in the glass industry for the design of structural glass products (1). For this application, safety factors run from 2.5 for plate glass windows to 8 for underwater windows which support uniform water pressures. The use of safety factors is an effective way of meeting design requirements when the material and the conditions of exposure are fully understood. For new applications, however, the use of safety factors entails a trial-and-error process to select a factor that is sufficient to assure safety. In order to encompass all possible exposure conditions, a considerable amount of empirical investigation is required for each design-material combination. Although the use of safety factors is the most common method employed for the design of structural ceramics, more effective methods of design have been developed which are based on a detailed understanding of the causes of failure in ceramic materials.

Newer techniques of design that have been developed over the past 10 years are based on the science of fracture mechanics. These techniques assume that fracture in ceramic materials originates from preexisting flaws, which grow when subjected to excessive stresses $(2,3)$. Fracture mechanics theory provides a basis for predicting the effect of these flaws on the strength and on the lifetime of ceramics that are subject to mechanical stresses. These theories of lifetime prediction are deterministic in nature, in the sense that once the size of the flaws and the resistance of the material to fracture have been determined, the failure time can be predicted. These techniques have been applied successfully to electronic substrate materials (4), windows for spacecraft $(5,6)$, grinding wheels $(7)$, optical fibers $(8)$, re-entrant heat shields (9-11) and ceramics for electronic capacitors (12). The theory has also been used to improve our understanding of complex processes such as thermal shock (13) and erosion (14).

Fracture mechanics based theories of lifetime prediction work very well as long as the mechanism of failure is, in fact, due to subcritical crack growth from pre-existing flaws'. If structural failure has its roots in other causes, then the fracture mechanics 
based theory can give, an erroneous prediction of lifetime. An example of the problems that can be encountered when failure is not the result of subcritical crack growth is illustrated by attempts to predict the lifetime of magnesia-doped, hot-pressed silicon nitride. Problems with this material arise as the result of chemical reactions between the silicon nitride and oxygen at elevated temperatures (15-28). At room temperature, the strength is determined primarily by surface flaws introduced into the material during machining and finishing operations. At high temperatures $\left(>1200^{\circ} \mathrm{C}\right)$, the machining flaws are altered as a result of chemical attack and increased atomic mobility that results in plastic deformation and diffusion within the silicon nitride. Because of these effects, the strength of hot-pressed silicon nitride is observed to increase during the initial stage of high temperature exposure, due to surface stress relaxation and crack healing. After long periods of exposure to stress and temperature, new flaws are formed and strength decreases as a result of creep cavitation $(26,27)$ and localized corrosion at the silicon nitride surface. Because of these factors, the fracture mechanics based theory of lifetime prediction, which assumes subcritical crack growth to be the sole cause of failure, is clearly limited.

When estimates of lifetime are made, processes that alter the type and density of flaws must be considered. Such considerations are especially important when the initial flaw population is eliminated as a cause of failure early in a particular structural application. When this happens, flaws generated during use are the prime causes of structural failure, and the time necessary for the flaw generation may amount to a significant fraction of the total expected lifetime. Processes that cause flaw generation at elevated temperatures are cavitation due to creep, pitting due to localized corrosion and phase transformations due to chemical interactions with the environment. Processes that cause flaw elimination are generalized corrosion, stress relaxation as a result of plastic flow, and crack healing as a result of high temperature sintering. Adequate lifetime procedures require that these processes be compared to determine which one controls the strength at a particular instant in time. In addition, subcritical crack growth, which is known to occur in some ceramics at elevated temperatures, must be factored into the failure prediction scheme.

In this paper, a general approach to the prediction of component reliability is suggested. The approach is more probabilistic in nature than either the fracture mechanics approach or the safety factor approach, and has been used in a broad range of applications to assure the reliability of both electronic and structural components (29). The approach is based on the assumption that both the applied stress, and the strength of a set of components can be described by probability density functions. The 
failure rate of the set of components is then determined by the time evolution and interference of the two density functions. In this paper, the concepts of fracture mechanics are factored into this general approach to structural rellability. It is shown that the fracture mechanics based crack growth theories can be used to provide a mechanistic understanding of the time evolution of the probability density function for strength. Thus, the fracture mechanics approach and the probability approach are complimentary in their use for improving the lifetime of structural ceramics.

GENERAL BACKGROUND $(29,30)$

In order to predict the probability of failure of a structural component, both the applied stress, $\sigma$, and the component strength, $\mathrm{S}$, must be known with some degree of certainty. When the strength is less than the stress for a given component, failure occurs. The strength and stress are expressed in terms of probability functions, which give the probability that component strength or applied stress lie within prescribed limits. Thus, if the probability density function for strength is given by $f_{s}(s)$, then the probability, $\mathrm{p}\left(\mathrm{S}_{\mathrm{O}}\right)$, of having the strength lie within a small interval of strength, dS, is given by

$$
\mathrm{P}\left(\mathrm{S}_{\mathrm{o}}-\mathrm{dS} / 2 \leq \mathrm{S} \leq \mathrm{S}_{\mathrm{o}}+\mathrm{d} \mathrm{s} / 2\right)=\mathrm{F}_{\mathrm{S}}\left(\mathrm{S}_{\mathrm{o}}\right) \mathrm{dS}
$$

A similar definition of the probability density function is used for the applied stress, $f(\sigma)$. It is worth noting that the cumulative failure probability (for a strength, $S$, less than some value $S^{*}$ ) used by most materials scientists is obtained from equation 1 by integration:

$$
P\left(S<S^{*}\right)=\int_{0}^{S *} f_{S}(S) d S
$$

where $f_{S}(S)$ is usually assumed to be a two parameter Weibull probability density function:

$$
f_{S}(S)=\frac{m s^{m-1}}{s_{0}^{m}} \exp \left[-\left(S / s_{0}\right)^{m} 1\right]
$$

These concepts of probability can be integrated with concepts of fracture mechanics by defining the strength in terms of the size, a, of the most critical crack in the component, and the critical stress intensity factor, $\mathrm{K}_{\mathrm{IC}}$, of the component:

$$
\mathrm{S}=\mathrm{K}_{\mathrm{IC}} /(\mathrm{Y} \sqrt{\mathrm{a}})
$$

where $Y$ is a factor that depends on the geometry of the crack. 
By plotting the probability density functions for strength and stress on a common set of axes, figure 1, the probability of failure for a component can be estimated from the portion of the figure where the two distribution function overlap: the crosshatched area in figure 1 (29). Within this area, there is a finite probability that some of the components will experience stresses that are greater than their strength. Methods of estimating the total failure probability are given in references 29 and 30 for a variety of density functions. For purposes of the present paper, the recognition that these functions and their time evolution determine the failure probability is important.

The probabilistic approach to structural reliability concentrates on methods of evaluating and modifying probability density functions for a given structural situation. The functions are then used to establish component and system lifetime and rejection criteria for structural applications $(29,30)$. Since the main interest of the present paper is in the material, the stress will be assumed to be constant for the remainder of the discussion. Although the importance of the stress distribution for lifetime predictions is recognized, this assumption is made to simplify further discussion and to concentrate on the properties of the material. Using this assumption, the failure probability is given by the area under the probability density function curve for which the values of strength are lower than the applied stress, figure 2.

\section{RELIABILITY CLASSIFICATIONS}

Reliability classifications for structural materials can be made on the basis of the character of the strength distribution function and its evolution with time $(29,30)$. The classifications of reliability can be divided into three types: deterministic; random-fixed; random--independent. These classifications have their basis in the precision with which the strength distributions are known.

\section{Deterministic Classification of Strength}

The deterministic classification is based on the assumption that the strength of the components and the evolution of their strength with time is known precisely. Given these conditions, then the strength of any component within the strength distribution can be calculated as a function of time and the time-to-failure can be determined. With regard to design techniques developed for ceramic materials, proof-testing and non-destructive evaluation techniques fall into this category. Proof testing or non-destructive evaluation are used to truncate the probability density function so that the weak components are removed from the strength 


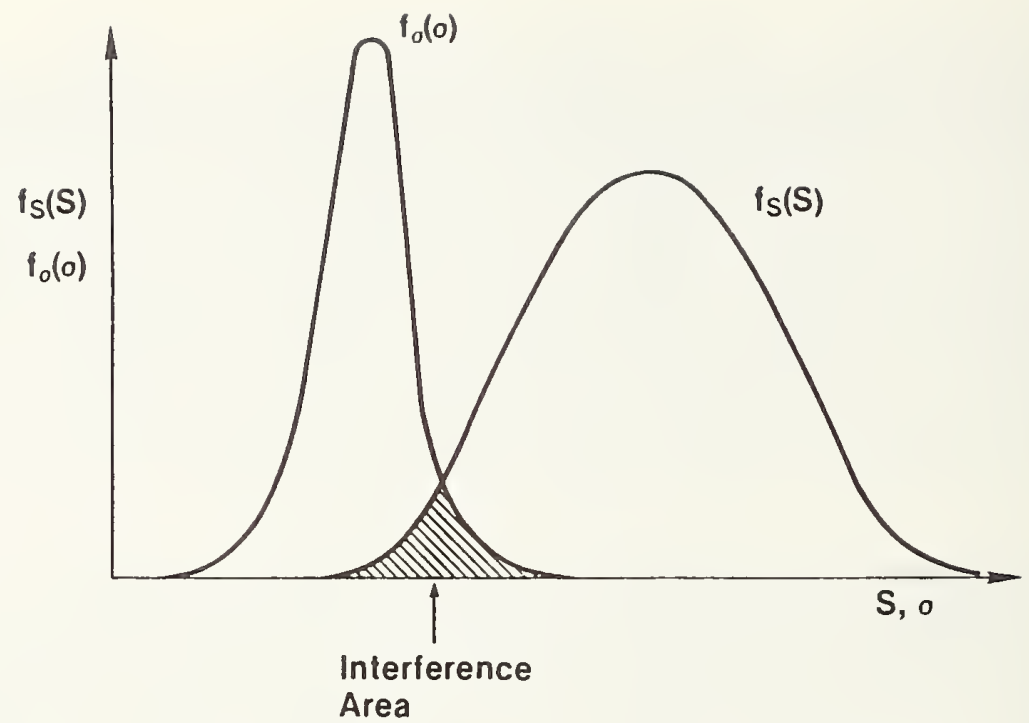

Fig. 1. Illustration of the interference theory of reliability. The interference area given by the overlap of the probability functions for stress and strength determines the failure probability (from Kapur and Lamberson 29).

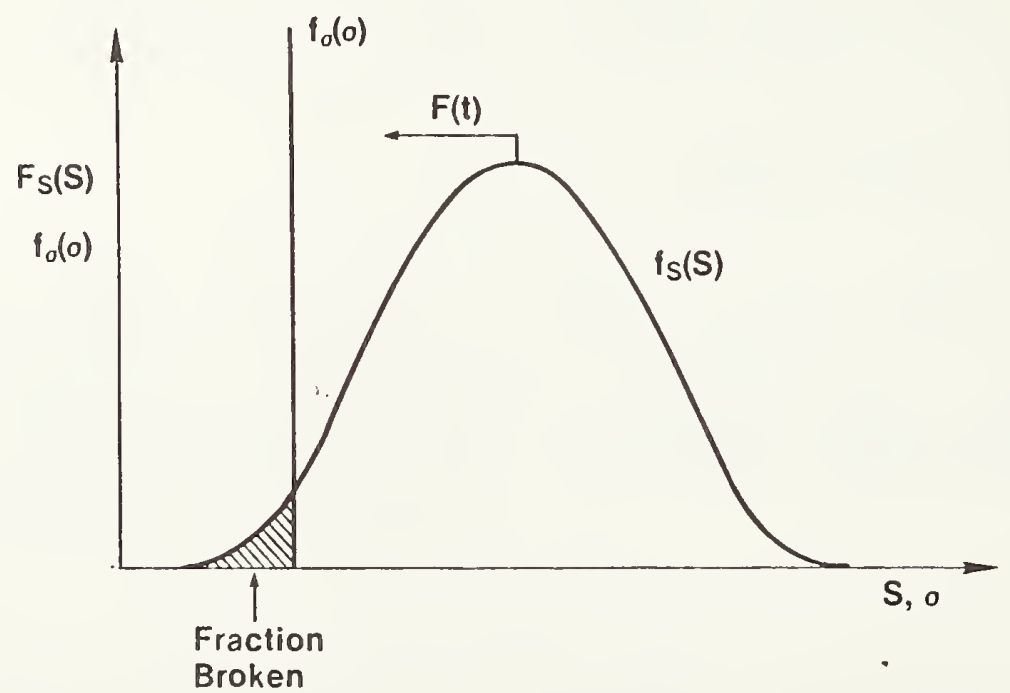

Fig. 2. Illustration of the interference theory of reliability, assuming the applied stress to be a well defined constant. The probability of failure, calculated from the shaded area under the strength curve, depends on time if the probability density function is time dependent. 
distribution, figure 3. The truncation serves to define a minimum strength for the population of components, which serves as a basis for estimating the minimum time-to-failure for the set of components.

Strength degradation is usually assumed to result from subcritical crack growth, and the minimum time to failure is calculated on this basis $(2,3)$. Fracture mechanics data suggest that the crack velocity, $v$, can be expressed as a power function of the applied stress intensity factor, $\mathrm{K}_{\mathrm{I}}$ :

$$
\mathrm{v}=\mathrm{v}_{\mathrm{o}}\left(\mathrm{K}_{\mathrm{I}} / \mathrm{K}_{\mathrm{O}}\right)^{\mathrm{n}}
$$

where $\mathrm{v}$ and $\mathrm{n}$ are empirical constants determined by a least squares ${ }^{\circ}$ it of experimental data and $\mathrm{K}_{\mathrm{o}}$ is an arbitrary constant required for dimensional stability of the equation. Using equation 5 as a mechanistic basis for strength degradation, the following equation has been derived for the minimum time to failure (3):

$$
t=B S_{P}^{(n-2)} \sigma^{-n}
$$

where $B$ and $n$ are parameters that characterize the crack growth and $S$ is the minimum strength of the truncated distribution. Severgl experimental techniques have been developed to measure $B$ and $\mathrm{n}$, and are adequately discussed in the literature $(3,11)$.

The attraction of proof testing, or non-destructive evaluation techniques for design lies in the precision with which these techniques can be used to make predictions of lifetime. If all of the parameters in equation 6 are known, then the minimum lifetime can be predicted accurately. Furthermore, the probability of failure at a time less than the minimum lifetime will be zero. In practice, errors of measurement always occur in the determination of the minimum lifetime, and the precision of the lifetime estimate is reduced by an amount that depends on the measurement error.

The measurement errors that enter into the lifetime prediction are of two types, those involved in the determination of $B$ and $n$, and those involved in the determination of $S_{p}$. Both types of error can be of sufficient magnitude to intrbduce a considerable degree of uncertainty into the estimate of the minimum time-tofailure. The errors in $B$ and $n$ are common sources of uncertainty to both the proof-test technique and the non-destructive testing technique. Therefore, regardless of which technique is used to truncate the probability density function, accurate crack growth data are required to evaluate $\mathrm{B}$ and $\mathrm{n}(11,32,33)$.

The errors involved in evaluating $S$ depend on the test technique used to evaluate $S$ (i.e. whether proof testing or nondestructive evaluation $t^{R}$ chniques are used to truncate the probability density function). In the absence of subcritical crack 


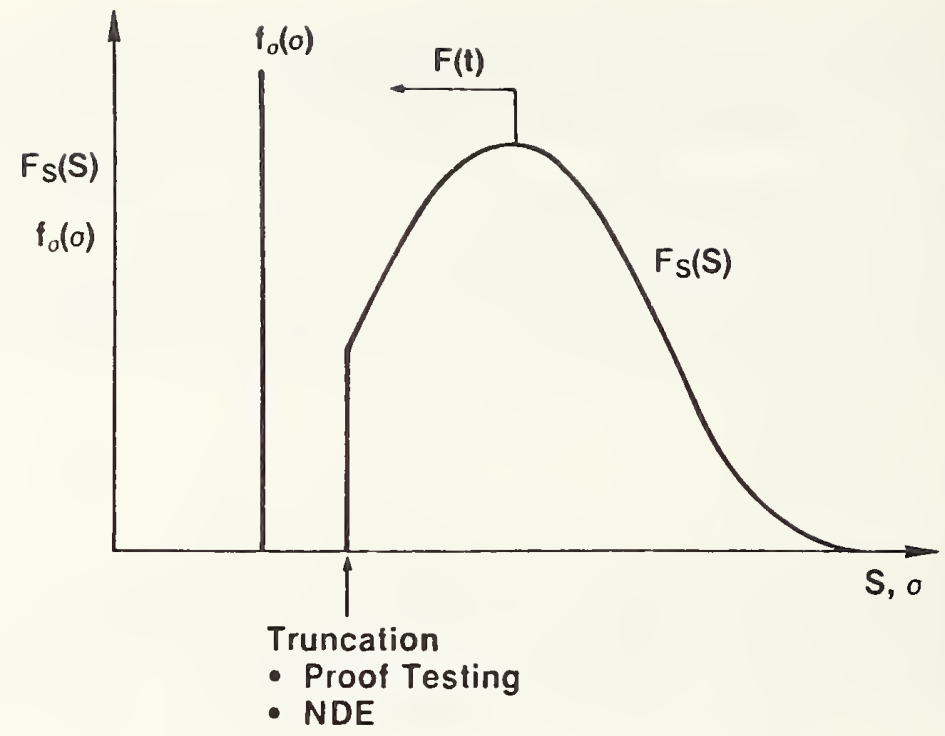

Fig. 3. Truncation of the probability density function by proof testing or non-destructive evaluation. The failure probability is zero until the truncated portion of the probability density function intersects the line of constant stress.

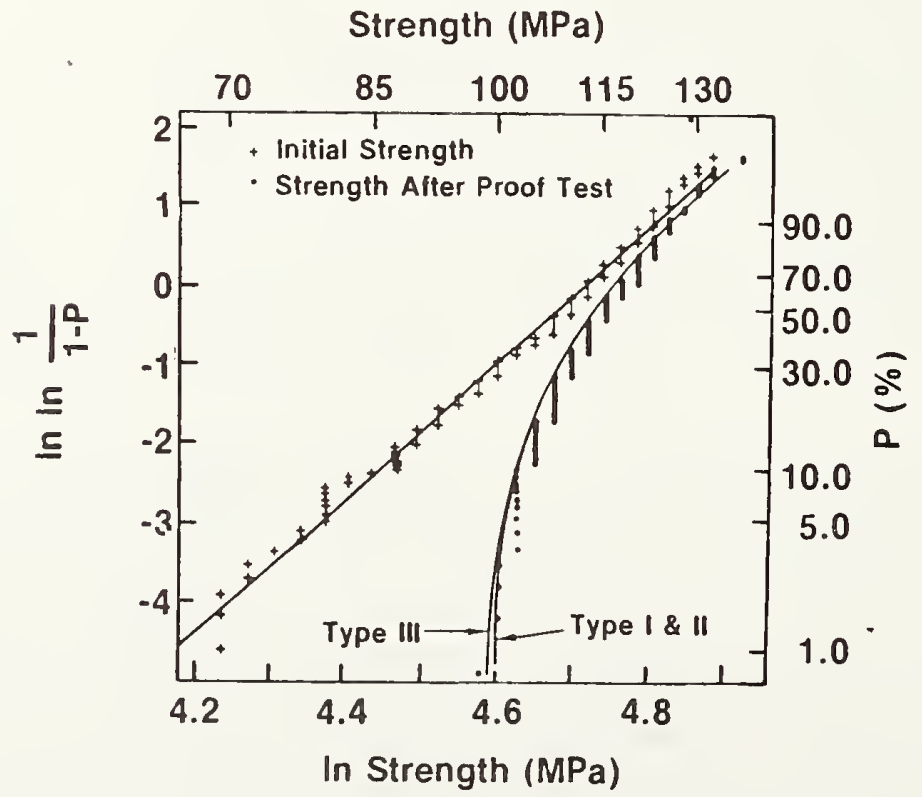

Fig. 4. Strength distributions for soda-lime-silica glass in dry nitrogen before and after proof testing; compared with theoretical curves type I, II and III (from Ritter et al. 49). 
growth, the errors involved in determining $S$ by proof-testing are determined by the error involved in establishing the proof-test load. This error can be very small as can be seen by the sharply truncated distributions that have been obtained on number of materials, figure 4. However, when subcritical crack growth occurs, the errors in $S$ are determined not by the proof-test load, but by the errors ${ }^{p}$ in $B$ and $n$, and by errors in the unloading rate, as can be seen from the following equation for $\mathrm{S}_{\mathrm{p}}$ (34):

$$
s_{p}=\left[B(n-2) \dot{\sigma}_{u}\right]^{1 / 3}[3 /(n+1)]^{1 /(n-2)}
$$

where $\dot{\sigma}_{\text {us }}$ is the rate of unloading during the proof test and $\mathrm{n}$ and $B$ relate to the crack growth parameters under the conditions of the proof test. These errors can be sizable and lead to considerable uncertainty in the predicted time-to-failure. Hence careful environmental control and accurate evaluation of $B$ and $n$ are required for reliability in proof testing.

Non-destructive techniques for evaluating the strength of materials are in a much earlier state of development than are the proof testing techniques just discussed (35). Consequently, the capability of the non-destructive techniques to truncate a strength distribution have not been thoroughly explored. With regard to establishing the truncation strength, the errors of measurement that are important are (1) those involved in measurement of the flaw size, and (2) those involved in characterization of the flaw behavior. Both types of measurement error can be sizable. The nature of these sources of error have been discussed recently in a number of references (35-37). However, there is at present insufficient data to completely evaluate the effect of these errors on the predicted time-to-failure.

of the non-destructive analysis techniques that have been developed, the surface analysis technique discussed by Khuri-Yakub et al. $(38,39)$ seems to be the most advanced. The technique is capable of detecting surface cracks that range in size from $\sim 50 \mu \mathrm{m}$ to $\sim 500 \mu \mathrm{m}$. Although systematic differences between measured and actual crack size occur when this technique is used, the precision of the technique seems to be of the same magnitude, as might be expected from proof testing in the absence of crack growth. Therefore, the surface ultrasonic technique offers promise of being an effective method of truncating the probability density function for strength. However, additional work is needed to fully assess the value of this technique for reliability analysis.

\section{Random-Fixed Classification of Strength}

The random-fixed classification of strength is based on the assumption that the time evolution of strength is well known, but that at any instant of time, the strength is known only as a 
function of probability. The position of the individual components within the strength distribution 1s, however, fixed relative to the other components within the distribution. Hence while the distribution may change with time, the relative position of the components in the strength distribution does not change with time. Despite the fact that the strengths are fixed in the distribution, the strength of a random component is determined only with regard to the probability density function, and therefore, is known only as a function of probability. Because of this property, the time to failure of a given component can be determined only as a function of probability.

In the absence of proof testing, or non-destructive evaluation, design with most ceramic materials at room temperature falls into the random-fixed classification. If subcritical crack growth occurs, then the lifetime of a component subjected to a stress, $\sigma$, is given by an equation that is similar to equation 6 :

$$
t=B S^{(n-2)} \sigma^{-n}
$$

where $S$ is now the strength of components as given by the probability density function. Quite often, the strength data for ceramic materials can be described by a two parameter Weibull analysis:

$$
\mathrm{S}=\mathrm{S}_{\mathrm{o}}\left[\ln (1-\mathrm{P})^{-1}\right]^{1 / \mathrm{m}}
$$

where $P$ is the fallure probability calculated from the probability density function. By substituting equation 9 into equation 8 we can see how failure time can be described in terms of failure probability.

As with proof-testing and non-destructive evaluation, the confidence in the lifetime prediction is sensitive to errors of measurement of the crack growth parameters $n$ and $B$. The lifetime prediction is also sensitive to errors in the determination of strength, $S$, as a function of probability. Of the two sources of uncertainty, the error in the strength relationship, $S=S(P)$, is usually the greater source of uncertainty in the lifetime prediction. This source of uncertainty is illustrated in figure 5 for strength data taken on hot-pressed silicon nitride after 64 hours of exposure at $1200^{\circ} \mathrm{C}$ in air. The central line in the figure represents a graphical estimate of the relationship between $S$ and $P$ based on a two parameter Weibull probability density function. The two curves to each side of the central line represent 90 percent confidence bands for the probability estimate, which was obtained using order statistics and a median value assignment of the probability. As a result of the uncertainty in the probability assignment, the uncertainty in strength ranges from approximately 100 to $200 \mathrm{MPa}$ depending on the probability level. These rather large uncertainties in strength are further magnified in estimating the time-to-failure 


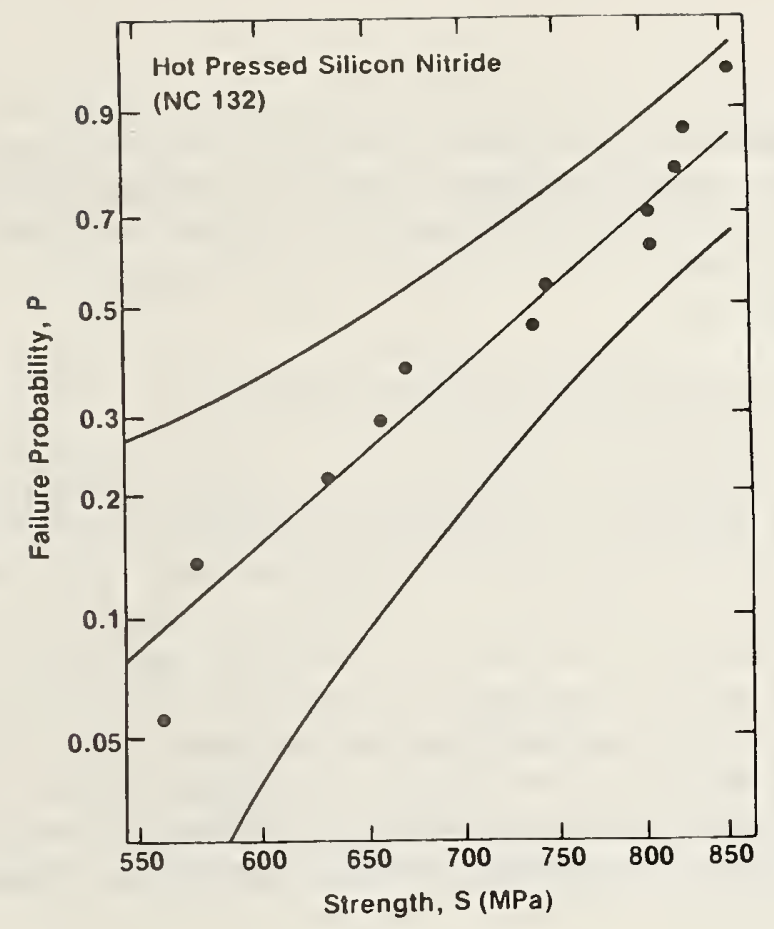

Fig. 5. Two parameter Weibull plot of strength data for hot-pressed silicon nitride (NC132). Specimens were first annealed in air at $1200^{\circ} \mathrm{C}$ for 64 hours under a stress of $250 \mathrm{MPa}$, then were broken at $1200^{\circ} \mathrm{C}$ without cooling to room temperature. The error bands represent 90 percent confidence limits on the median line.

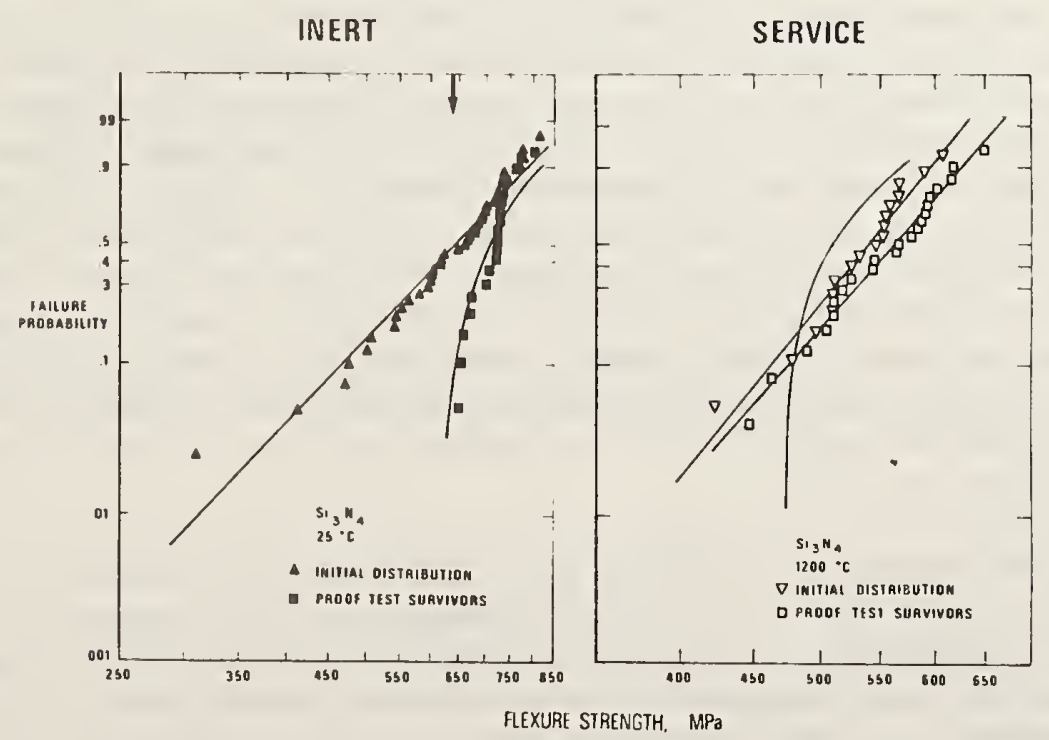

Fig. 6. Proof Testing conducted on hot-pressed silicon nitride (NC132) in air at room temperature: (a) broken at room temperature immediately after the proof test; (b) broken at $1200^{\circ} \mathrm{C}$ after being annealed for one-half hour at $1200^{\circ} \mathrm{C}$. (from Wiederhorn and Tighe 20). 
because of the exponent, $n$, in equation 8 . These sorts of uncertainties require the applied stress to be decreased substantially to retaln confidence in the lifetime prediction (11, 40). Recent publications dealing with this source of uncertainty are given in reference 33,29 and 41 .

\section{Random-Independent Classification of Strength}

The random-independent classification of strength is based on the assumption that both the strength variable and the time evolution of the strength variable are random quantities. The time evolution of strength is random in the sense that the strength of a component at any instant in time (or during any load or thermal cycle) is unrelated to the strength at any previous or subsequent time. A consequence of this definition is that the strength of a component is not fixed relative to the strength of the other components in the strength distribution. Therefore, the position of the components within the strength distribution can change with time.

An implication of random-independent behavior is that proof testing or non-destructive evaluation are no longer effective means of design, since a distribution that has been truncated at one point in time may lose its truncated character because of the reordering of components within the strength distribution. An example of this type of behavior has been reported by Wiederhorn and Tighe (20) for hot-pressed silicon nitride (NC 132). A set of specimens that had been truncated at room temperature by prooftesting was compared with a second set that was not truncated (20). Both sets were broken after an exposure of only one-half hour at $1200^{\circ} \mathrm{C}$. The distribution of strengths of the two sets of specimens were essentially identical, figure 6, indicating that the heattreatment had eliminated the truncated character of the set of specimens that had been proof-tested. In this experiment, the randomness was the result of uneven annealing of surface damage in the two sets of components. Other examples of random-independent behavior have been reported by Wiederhorn and Tighe (20), and more recently by Jakus et al. (42) for thermal cycling of hot-pressed silicon nitride (NC 132).

Random independent strength behavior must be treated by probabilistic techniques. A simple example of this type of behavior can be given for thermal cycling. During thermal cycling the flaw distribution of each component can be changed as a result of the thermal stresses and the annealing that occurs during each cycle. It will be assumed that at some point in the cycle a stress, $\sigma$, is applied to the components, and then removed. It is also assumed that at that point in the cycle, the probability function for strength is independent of the number of cycles. For this situation, the position of the components within the distribution can change 
even though the distribution function, $f_{S}(S)$, is independent of the number of cycles. The reliability, $\$$ (probability of survival) of the components after $n$ cycles is given by:

$$
\mathrm{R}_{\mathrm{n}}=\left[\int_{\sigma}^{\infty} \mathrm{f}_{\mathrm{s}}(\mathrm{S}) \mathrm{d} \mathrm{S}\right]^{\mathrm{n}}
$$

It is worth noting that as the number of cycles increases, the chance of survival decreases. Such would not be the case for a random-fixed distribution. For the same situation, the reliability of a random-fixed distribution would be given by:

$$
R_{n}=\int_{\sigma}^{\infty} f_{S}(S) d S
$$

Without a separate time dependence of $f_{s}(s)$, the number of components that break from a random-fixed distribution would not depend on the number of cycles; all the components would break during the first cycle. A more general approach to reliability estimates using the random-independent classification, requires a deeper understanding of the way in which flaws are nucleated and annealed in ceramic components as a function of time. This type of approach to failure prediction has not been applied to ceramic components.

\section{STRENGTH DEGRADATION MAPS}

In earlier sections of the paper, the importance of probability density functions for design purposes was emphasized. The time evolution of these functions was discussed as a means of predicting minimum operating lifetime, or lifetime as a function of probability. In this section a graphical method of representing the time evolution of the probability density function is presented. Although the method is basically probabilistic in nature, crack propagation and detailed flaw generation modes can be incorporated into the method to give a more accurate picture of component lifetime under load. The method centers about the construction of a strength degradation map, which relates strength, failure time and failure probability on a single diagram. These maps give a general picture of the strength behavior of ceramics, and as such, are similar to the deformation maps, and fracture maps first suggested by Ashby (43).

The discussion presented in this section will proceed by example, starting with a simple map in which the probability density function is time-invariant, and finishing with a map that includes flaw generation, flaw healing and crack propagation. This step-wise procedure is used to familiarize the reader with each aspect of these maps so that the final map can be readily understood. This procedure is especially important when concepts of static fatigue and flaw generation are introduced. 


\section{Basic Definitions}

The time evolution of strength distributions can be represented on a diagram in which the strength is plotted as the ordinate and the time is plotted as the abscissa. A schematic view of such a diagram is shown in figure 7 for the case in which neither strength degradation nor strength enhancement occurs as a function of time. To the left of the strength degradation diagram is a probability density function that represents the initial strength distribution of a set of specimens or components. The application of a stress will cause a fraction of the components to break. This fraction is given by the area under the probability density function indicated by the letter $A$; the fraction that survives is indicated by the letter $B$.

On the strength degradation diagram a component fails when its strength is less than the applied stress shown by the horizontal line in the diagram. Hence, the area on the strength degradation diagram that lies below the horizontal line labelled "applied stress" represents the fraction of components that have broken. The lines shown on the upper part of the diagram represent the failure probability of components that survived the applied stress. These failure probabilities are based on the initial distribution of strength, so that the first probability line has a value given by area $A$ under the probability density function. Thus if the fraction of components that failed on application of load is 0.1 , then the first probability line will be 0.1 and all other probabilities will be greater than this value.

From an experimental point of view, the failure probability of components that survive the applied stress can be determined by increasing the stress to break all of the components. Then, if the initial strength distribution is represented by a two parameter Weibull distribution, the components above the constant stress line will be represented by a truncated Weibull distribution having the same value of So and $\mathrm{m}$ as the original distribution, figure 8. The probabilities given in figures. 7 and 8 are determined by order statistics using the total number of components in the initial distribution as a basis for calculating the failure probability. For the case in which strength is invariant in time, figure 7 , the lines of constant probability are horizontal.

\section{Crack Growth and Crack Healing}

Crack growth from the initial flaw population will alter the appearance of the diagram shown in figure 7. The growth of cracks causes the strength of components to degrade so that the probability lines are no longer invariant in time. As the strength decreases, each of the probability lines curves downward, gradually approaching the line of constant applied stress. Intersection of 


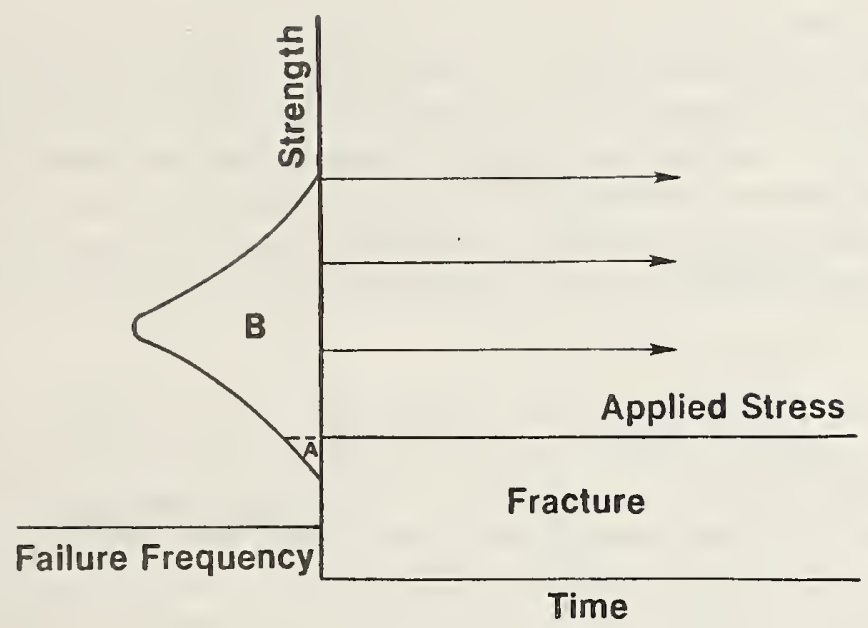

Fig. 7. Strength degradation diagram for time invariant distribution. Specimens represented by region A under the probability density function are broken by the applied stress. The strengths of the remainder of the population are invariant in time.
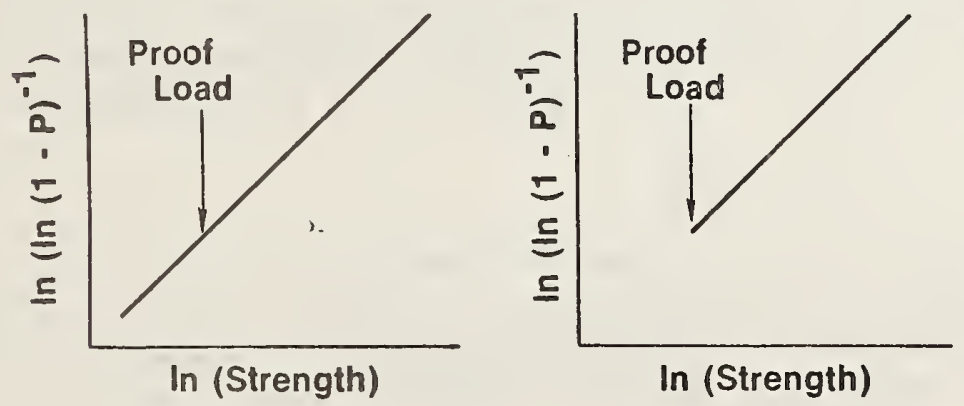

Fig. 8. Effect of proof stress on time invariant strength distribution. Probability estimate is based on the initial population size: (a) Distribution before application of the proof 1oad; (b) distribution after application of the proof load. 
the probability lines with the stress line represents an increasing fraction of components broken as a result of the applied stress. The diagram shown in figure 7 also will be altered in appearance if crack healing (or any other stress relieving process) occurs. As the time of exposure increases, the effective size of the cracks in the components decreases causing an increase in component strength. As a consequence, the probability lines move to higher values of strength.

A simple illustration of the effect of crack growth and crack healing can be given for the case in which crack healing and crack growth occur simultaneously, figure 9. Since these processes have an opposite effect on the strength, they will be competitive when they occur simultaneously, and a boundary will exist on a strength degradation map separating the two processes. This boundary is similar to the static fatigue limit in glass which separates crack growth from crack blunting when glass is subjected to a mechanical stress in a moist environment. If crack healing occurs by generalized corrosion (i.e. hot-pressed, silicon nitride), then the fatigue limit can be defined as the strength for a crack of length, $\mathrm{a}^{+}$, that is invariant with time (i.e. the rate of crack growth is just compensated by the rate of crack healing). If we assume that crack healing is solely the result of crack shortening due to corrosion of the surface, figure 10, then the fatigue limit occurs when the rate of crack growth, $v$, is just equal to the rate of surface recession, $V$, due to corrosion.* If the crack velocity in ceramic materials can be represented as a power function of the applied stress intensity factor (eq. 5), then the stress corrosion limit is obtained when $v=V$ is given by the following equation:

$$
\mathrm{V}=\mathrm{v}_{\mathrm{o}}\left(\mathrm{K}_{\text {ISCC }} / \mathrm{K}_{\mathrm{o}}\right)^{\mathrm{n}}
$$

where $\mathrm{K}_{\text {ISCC }}$ represents the stress intensity factor of the crack which has a length that is invariant in time. If the rate of generalized corrosion, $\mathrm{V}$, and the crack growth behavior have been characterized, then $\mathrm{K}_{\mathrm{ISCC}}$ can be determined from equation 12 for a given experimental condition.

From fracture mechanics considerations it can be demonstrated that:

$$
S_{f}=\sigma\left(K_{I C} / K_{I S C C}\right)
$$

\footnotetext{
* The discussion presented here is for a material such as silicon nitride which oxidizes at elevated temperatures.
} 


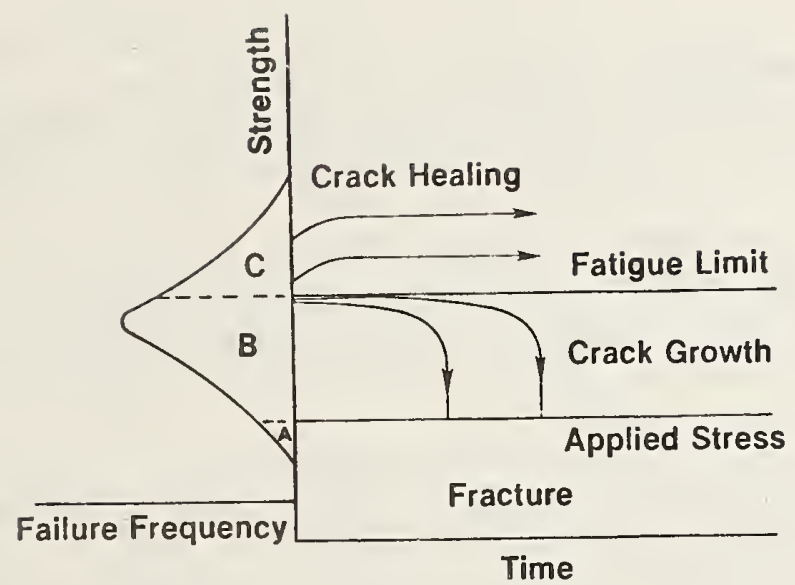

Fig. 9. Strength degradation diagram for the case in which crack healing and crack growth occur simultaneously. Specimens in area $A$ under the probability density function break upon application of stress; specimens included in area B break as a result of subcritical crack growth; specimens in area $C$ survive the load application.

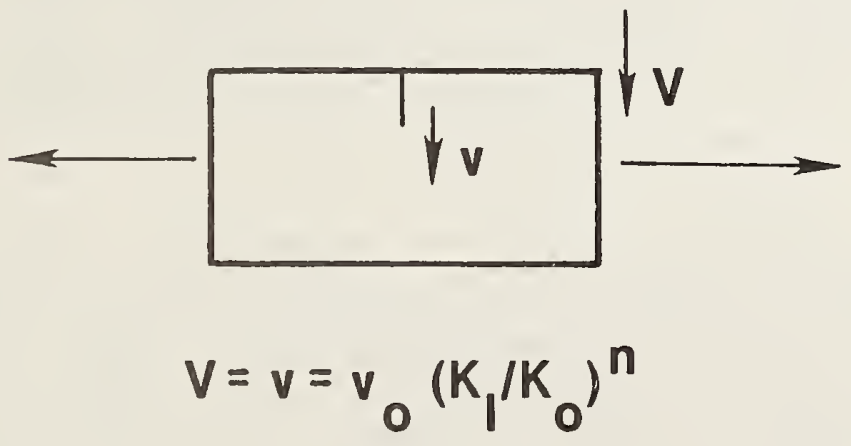

Fig. 10. A schematic model of crack growth accompanied by surface dissolution: $v$ is the crack velocity, $V$ is the velocity of surface dissolution. 
where $S_{f}$ is the strength that defines the boundary between crack growth and crack healing on figure 9. Since $\mathrm{K}_{I C}>\mathrm{K}_{I S C C}$, $\mathrm{S}_{\mathrm{f}}$ is larger than the applied stress, $\sigma$. This result ls consistent with the fracture mechanics concept of a fatigue limit. As the crack size gets smaller, the strength increases, and for a constant applied stress, the stress intensity factor decreases. Hence, crack growth does not occur for cracks smaller than the value $\mathbf{a}^{+}$, which is determined for a given applied stress when $\mathrm{K}_{\mathrm{T}}=\mathrm{K}$ Therefore, crack growth on figure 9 does not occur for $S>S_{f}{ }^{\circ}$

Crack healing and strength enhancement will occur for initial strengths that are greater than the fatigue limit, whereas crack growth and strength degradation will occur for initial strengths that are below the fatigue limit, figure 9. Again, each of the curves on figure 9 represent equal probabilities of failure; the diagram gives the time evolution of the strength distribution. The intersection of the probability lines in the crack growth region with the constant stress axis corresponds to component failure. A1l of the components with initial strengths that are less than the fatigue limit will eventually fail. These components correspond to area $B$ under the probability density function curve in this figure.

The static fatigue limit will depend on the thickness of the oxide scale that forms on the ceramic surface and on its ability to protect the surface against further oxidation. If the surface layer is not protective then the rate of surface attack, V, will be a constant, and the static fatigue limit, will be given by:

$$
\mathrm{S}_{\mathrm{f}}=\sigma\left(\mathrm{K}_{\mathrm{IC}} / \mathrm{K}_{\mathrm{o}}\right)\left(\mathrm{V} / \mathrm{v}_{\mathrm{o}}\right)^{-1 / \mathrm{n}}
$$

If the surface layer is protective then $\mathrm{V}$ will not be a constant, but will decrease with time as the thickness of the surface layer increases*. As the surface layer becomes more protective, the rate of crack healing will decrease, and the strength that is equal to the fatigue limit will increase. For a parabolic oxidation law in which the rate of oxidation is limited by transport through a protective layer:

$$
\mathrm{V}=\mathrm{v}_{\mathrm{o}}\left(t / \mathrm{t}_{\mathrm{o}}\right)^{-1 / 2}
$$

Substituting equation 15 into equation 14, the following equation for the fatigue limit is obtained:

*Changes in the oxidation rate of the surface may also occur as a result of chemical modification of the surface. Such modification has been reported for hot-pressed silicon nitride (22). In this case the effective barrier to corrosion will be the modified surface of the ceramic and not the surface oxide layer. 


$$
S_{f}=S_{f o}\left(t / t_{0}\right)^{1 / 2 n}
$$

where $\mathrm{S}_{f_{0}}=\sigma\left(\mathrm{K}_{I C} / \mathrm{K}_{0}\right)\left(\mathrm{V}_{\mathrm{o}} / \mathrm{v}_{\mathrm{o}}\right)^{-1 / \mathrm{n}}$. Since $\mathrm{n}$ ranges from $\sim 10$ to $\sim 100$ for ceramic materials at elevated temperatures, the fatigue limit gradually increases with time.

The rate of healing and the rate of strength degradation depend on the rate of crack growth relative to the free surface, provided the oxide layer has zero strength (as it will for glass or slag on a ceramic surface). The strength is determined by the Griffith equation (i.e. eqn. 4). If the crack growth rate v exceeds the rate of recession of the ceramic surface, $V$, then the crack length, a, will increase and the strength of the component will decrease. Conversely if $\mathrm{V}>\mathrm{v}$, the crack length will become shorter and the strength will increase. As flaws resulting from machining and polishing are removed, and others typical of bulk defects such as pores and inclusions take their place, the flaw structure of the surface will be modified by corrosion.

Figure 9 presents a schematic representation of the type of crack healing and strength degradation expected on ceramic materials that are subject to corrosive attack. The fatigue limit is represented as a line of constant strength (which assumes $\mathrm{V}=$ constant). In the crack healing regime the lines of constant failure probability gradually increase in strength until all of the initial flaws are removed and a new distribution of surface flaws is obtained that is typical of the bulk material. Because the high probability curves represent higher strength specimens which contain smaller cracks, components that lie at the high probability end of the initial strength distribution will reach the final surface state first. Components from the initial strength distribution that lie close to the fatigue limit will require a longer period of time to reach the final strength distribution because they contain larger cracks. Finally since the distribution of flaws that typify the final distribution may differ considerably from the initial distribution, both Weibull moduli, $\mathrm{S}$ and $\mathrm{m}$, may change in time, so that the lines of constant probability in the crack healing regime of figure 9 will not necessarily be parallel.

In the crack growth regime, the strength of components will decrease until fracture occurs. when $S=\sigma$. Crack growth will be slow for components that contain cracks that lie close to the fatigue limit. Because of the strong dependence of crack growth rate on $\mathrm{K}_{\mathrm{I}}$, equation 5 , crack growth will accelerate rapidly prior to fracture, and the strength degradation curves will have a shape similar to those shown in figure 9. Components that have strengths that lie close to the applied stress line, will suffer rapid crack growth from the initial application of load, and fracture will occur very soon after load is applied to the specimen. Finally if 
only crack healing and crack growth occur, the number of failures that occur will gradually diminish with time until nearly all of the specimens indicated by area $B$ under the probability density function have been broken. After that, no failure will occur.

The ideas presented above can be expressed quantitatively by deriving a relation for the crack velocity relative to the corroding interface. At any instant in time, the crack velocity, $v$, will be given by equation 5, diminished by the rate of motion of the specimen surface as a result of corrosion:

$$
v=v_{0}\left(K_{I} / K_{0}\right)^{n}-v
$$

This equation is independent of the functional form of the law assumed for the corrosion rate. For a real material the parameters $\mathrm{v}, \mathrm{n}$ and $\mathrm{V}$ may be time dependent. The parameters $\mathrm{v}_{0}$ and $\mathrm{n}$ can change as a result of chemical modification of the cerramic surface, as it does for sialons, (45) while $\mathrm{V}$ will depend on the type of barrier that is formed on the ceramic surface as a result of high temperature exposure.

The rate of strength degradation can be calculated directly from equations 4 and 17:

$$
\mathrm{dS} / \mathrm{dt}=-\left[\left(\mathrm{Y} / \mathrm{K}_{\mathrm{IC}}\right)^{2} \mathrm{~S}^{3} / 2\right]\left[\mathrm{v}_{\mathrm{o}}\left(\mathrm{K}_{\mathrm{I}} / \mathrm{K}_{\mathrm{o}}\right)^{\mathrm{n}}-\mathrm{V}\right]
$$

The most direct means of obtaining the strength trajectories shown on figure 9 is by numerical integration of equation 18. For a real material, the regions of crack growth and crack healing on figure 9 may be missing. For example, if subcritical crack growth does not occur, the fatigue limit line will be concurrent with the applied stress line and the region for crack growth will be missing from the strength degradation diagram.

\section{Flaw Generation}

The strength degradation diagram will become much more complicated if new flaw populations are generated during the course of exposure. As illustrated in figure 11 , new flaws can be generated in ceramic materials in a number of ways. The simplest involves the dissolution of flaws due to machining, and the simultaneous exposure of microstructural defects such as pores or

\footnotetext{
* Michalske (44) has made this same observation for the static fatigue of glass. Because of the existance of a fatigue limit in soda lime silica glass, he predicts that fractures will not occur under static loading conditions for times greater than $10^{6} \mathrm{sec}$. His prediction seems to be consistent with experimental findings.
} 


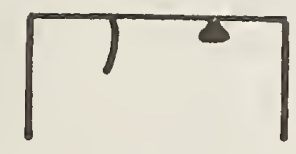

(a)

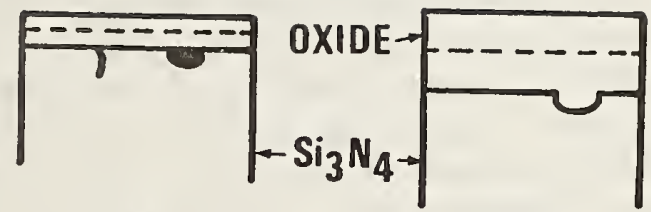

(b)

(c)

Fig. 11. Effect of oxidation on flaw generation in hot-pressed silicon nitride: (a) initial surface; (b) dissolution of machining flaw and oxidation of inclusion; (c) machining flaw eliminated, pit remaining from localized oxidation of inclusion.

(a)

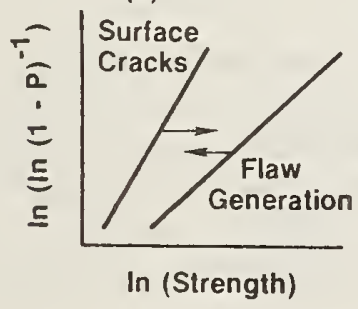

(b)

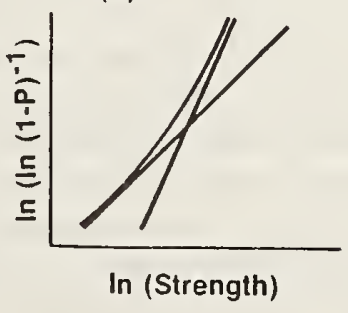

Fig. 12. Illustration of the evolution of strength distributions during exposure to elevated temperatures and high stresses: (a) Initial stresses distributions; (b) distributions after the two initial distributions have intersected. 
inclusions that are present in the bulk of the material. New flaws may also be generated as a result of localized oxidation in the surface of the ceramic caused by chemically reactive inclusions within the solfd, or by localized regions of activity in the oxide surface layer that form during exposure. Such localized oxidation has been reported to cause pits to form on the surfaces of magnesiadoped, hot-pressed silicon nitride (17-20,25). Another mechanism of flaw formation occurs if the material undergoes creep at elevated temperatures $(26,27)$. Unless creep can be accommodated by deformation of the grains of the solid, grain boundary sliding will result in the formation of small cavities in the solid, which can then act as fracture nuclei.

Because of the stochastic nature of the flaws that are generated at elevated temperatures, the strength will have a statistical distribution that differs from that due to machining flaws, which are removed as a result of oxidation. The distribution of strengths that represents the new set of flaws may have a value of $S$ and $m$ that differ substantially from the initial set of surface llaws. Furthermore, the Weibull moduli, $S$ and $m$, may be a function of time. Therefore as the strength of the components begins to be influenced by the newly generated flaws, the Weibull distributions of both kinds of flaws will overlap, and the combined distribution must be used to determine the strength as a function of probability.

A schematic representation of the combined influence of two Weibull distributions is shown in figure 12.* Initially, the damage caused by machining determines the strength, because the strength distribution determined by machining flaws has lower strengths for all levels of probability. With time the two distributions overlap, and the failure probability, $P$, at a given value of strength is given by (46):

$$
1-\mathrm{P}=\left(1-\mathrm{P}_{1}\right)\left(1-\mathrm{P}_{2}\right)
$$

\footnotetext{
*In this figure, we assume that the Weibull slope for both distributions is time invariant. The parameter $S$ is assumed to depend on time. For simplicity, the treatment given here is based on the assumption that the two distributions are coherent. For a discussion of the more complicated situation of partially coherent, or exclusive strength distributions the reader is referred to reference 46 .
} 
where $\mathrm{P}_{1}$ and $\mathrm{P}_{2}$ are the fallure probabilitles for the initial flaws and the newly generated flaws respectively. The effect of both strength distributions will be equal when $P_{1}=P_{2}$ (i.e. at the point of intersection of the two distributions). ${ }^{2}$ At lower values of $P$, the distribution with the smaller value of $m$ will control the strength, whereas at higher values of $P$, the distribution with the higher value of m will control the strength.

A boundary between two sets of flaws that control strength can be established on a strength degradation diagram by setting $\mathrm{P}_{1}$ $=\mathrm{P}_{2}$ and by solving for the point of intersection of the two lines that represent the Weibull distribution of the two sets of flaws. In terms of the Weibull moduli the value of $S$ at the point of intersection is given by:

$$
\ln \mathrm{s}=\left(\mathrm{m}_{1} \ln \mathrm{s}_{1}-\mathrm{m}_{2} \ln \mathrm{s}_{2}\right) /\left(\mathrm{m}_{1}-\mathrm{m}_{2}\right)
$$

and the corresponding probability, $P$, is given by

$$
(1-\mathrm{P})=\left(1-\mathrm{P}_{1}\right)^{2}
$$

since $\mathrm{P}_{1}=\mathrm{P}_{2}{ }^{*}$. If the Weibull moduli for both distributions are known as a function of time then equations 20 and 21 define a boundary on a strength degradation diagram, figure 13, that separates regions in which the strength is controlled by a single population of flaws. Although the above derivation was presented in terms of an initial surface flaw population, and a newly generated population, the results are applicable whenever one set of flaws replaces another. Furthermore, the same analyses applies when the strength distributions do not form a straight line on a Weibull type of plot. For this case, graphical methods must be used to determine the line of intersection on figure 13.

To complete the strength degradation diagram, the condition that defines the change from flaw generation to crack growth has to be defined. The rate of strength degradation of flaws that are generated in the ceramic can be determined from the Weibull equation that describes the strength distribution. If the Weibull moduli m and $S$ are a function of time then the strength, $S$, of a component will also be a function of time. The rate of strength degradation resulting from crack growth can be determined from fracture mechanics considerations (34), as was done in section 4.2. The dominant process (flaw generation or crack growth) will be the one that

\footnotetext{
* The subscripts in equation 20 correspond to the two probability functions shown in figure 12.
} 


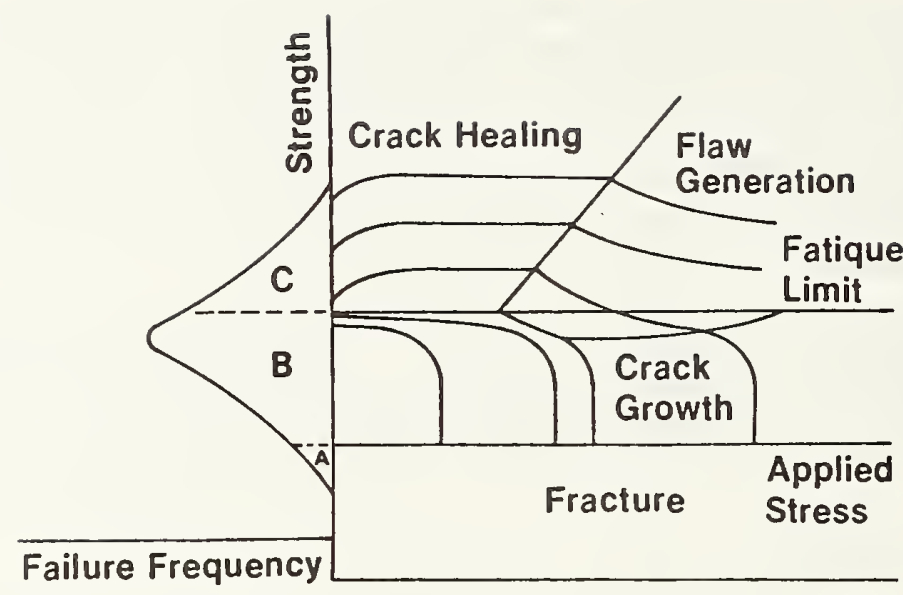

Time

Fig. 13. Strength degradation diagram indicating flaw generation during exposure. Interpretation of the regions $A, B$ and $C$ under the probability density function are given in figure 9 .

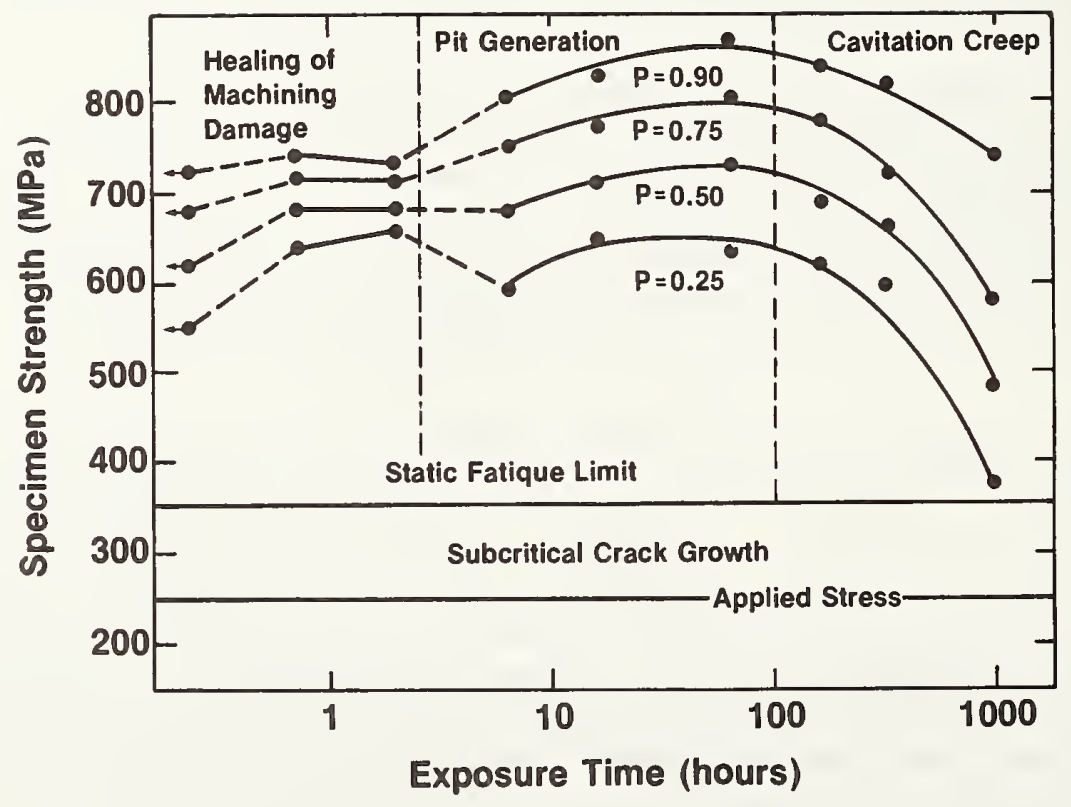

Fig. 14. Strength degradation diagram for magnesia-doped, hotpressed silicon nitride (NC-132). The diagram illustrates four regimes of strength degradation or strength enhancement. 
gives the highest rate of strength degradation, and the boundary between flaw generation and crack growth will be determined when these two processes occur at an equal rate:

$$
(\mathrm{dS} / \mathrm{dt})_{\text {flaws }}=(\mathrm{dS} / \mathrm{dt})_{\text {cracks }}
$$

This condition for the transformation from flaw generation to crack growth is similar to that used to establish the fatigue limit.

A hypothetic example of the type of boundary that occurs between the regions of crack growth and flaw generation is given in figure 13. The boundary is determined from the points of inflection of the lines of constant probability; the boundary is an envelope of these points. The boundary that separates flaw generation from crack growth will depend on the rate of strength degradation within the region of flaw generation, and in general, will not be contiguous with the fatigue limit established from considerations of surface corrosion.

\section{Empirical Methods of Establishing Boundaries}

In principle, the boundaries on the strength degradation diagram can be determined from a detailed theoretical and experimental analysis of the mechanisms of flaw generation within each region of the diagram. The boundaries of each region are determined from the boundary conditions given by equations 13, 19 and 22. This is the same sort of procedure followed by Ashby in the construction of fracture and deformation maps (43). Unfortunately, the detailed mechanistic understanding needed for construction of these boundaries is not available in the ceramics literature at the present time. Although work has been carried out on the theory of cavitation during creep (47), our state of understanding is not yet sufficient for the construction of strength degradation diagrams from theoretical considerations. Furthermore, the theories that have been developed have not been completely verified experimentally. Consequently, an alternative method is needed to determine the structure of strength degradation diagrams.

Strength degradation diagrams can be evaluated directly from strength measurements and microstructural analysis of ceramic specimens that have been exposed to a temperature and load for specified times. By breaking sets of specimens after fixed times of exposure, the strength distribution can be obtained as a function of time. The failure probability is determined directly from the strength distribution. By using the result of a series of strength tests made as a function of time, the failure probability lines can be plotted on the strength degradation diagram. If the strength data is obtained in sufficient detail, then the 
spacing and slopes of the probability lines will tend to change at the boundaries between the different regions of the strength degradation diagram. The boundary of each region may be selected by the use of equations 19 and 22. The mechanism of failure within each region of flaw generation is determined by microstructural analysis of the specimens. A fracture surface analysis, for example, can be used to determine the source of failure, eg. pits, pores, inclusions, whereas a microstructural analysis can be used to determine the extent of cavitation within the solid. Although tedious in its application, this method of establishing the strength degradation diagram is unequivocal with regard to identifying the regions on the diagram. Furthermore, the data can be used to obtain a basic understanding of the mechanism of failure of ceramic materials at elevated temperatures.

An example of the type of analysis just described is given in figure 14 for magnesia-doped, hot-pressed silicon nitride (48). Four-point, bend specimens of this material at a maximum fiber stress of $250 \mathrm{MPa}$ were exposed to air at a temperature of $1200^{\circ} \mathrm{C}$. The figure clearly illustrates that there are several regions to the strength behavior. For periods of time less than 0.5 hours exposure under load, stress relaxation as a consequence of high temperature dislocation mobility results in a strength increase. Between 0.5 hours and 2 hours of exposure only slight changes in strength occur suggesting that residual stress relaxation in the vicinity of the initial machining flaws has been completed. Between 2 and 4 hours of exposure, pit generation in the ceramic surface results in a radical change in the distribution of strength for the test specimens. As indicated by the apparent discontinuity in the probability curves, pit formation occurs quite rapidly and in a random way between 2 and 4 hours of exposure, so that there is no relation between the initial set of flaws caused by machining, and the pits resulting from localized oxidation. Between 4 and 16 hours of exposure, the pits become less severe as sources of failure and a plateau is reached in the probability curve suggesting that new pits are not generated after this time. At approximately 1 week exposure time, creep of the specimens under the applied load increases, and creep-fracture takes over as the dominant mode of failure. Thus, for magnesia-doped, hot-pressed silicon nitride, there are at least 4 regions of strength control: (1) subcritical crack growth; (2) machining flaws; (3) pits; and (4) cavitation cracks. An advantage of a diagram such as that shown in figure 14 over other methods of representing strength data is that it gives perspective to the strength behavior of the silicon nitride. As in the case of the deformation maps first proposed by Ashby, (43) the diagram delineates those regimes of stress that should be avoided by the designer, and the time frame over which specific strength behavior is to be expected. 


\section{ACKNOWLEDGEMENT}

The author is pleased to acknowledge the support of the Department of Energy, Division of Fossil Fuel Utilization.

\section{REFERENCES}

1. "Glass Product Recommendations: Structural," P.P.G. Technical Service Report, No. 101.

2. S. M. Wiederhorn, "Reliability, Life Prediction, and Proof Testing of Ceramics," pp. 635-55 in Ceramics for High Performance Applications, ed. by J. J. Burke, A. G. Gorum, and R. N. Katz, Brook Hill Pub. Co., Chestnut Hill, MA. (1974).

3. J. E. Ritter, Jr., "Engineering Design and Fatigue Failure of Brittle Materials," pp 667-686 in Fracture Mechanics of Ceramics, Vol. 4, ed. by R. C. Bradt, D. P. H. Hasselman and F. Lange, Plenum Press, N.Y. (1978).

4. J. N. Humenik and J. E. Ritter, Jr., "Susceptibility of Alurina Substrates to Stress Corrosion Cracking During Wet Processing," Bull. Am. Ceram. Soc. 59, 1205 (1981).

5. S. M. Wiederhorn, A. G. Evans, and D. E. Roberts, "A Fracture Mechanics Study of the Skylab Windows," pp. 829-41 in Fracture Mechanics of Ceramics, Vol. 2 ed. by R. C. Bradt, D. P. H. Hasselman and F. Lange, Plenum Press, New York (1974).

6. S. M. Wiederhorn, A. G. Evans, E. R. Fuller, and H. Johnson, "Application of Fracture Mechanics to Space-Shuttle Windows," J. Am. Ceram. Soc. 57 319-23 (1974).

7. J. E. Ritter, Jr., and S. A. Wulf, "Evaluation of Proof Testing to Assure Against Delayed Failure," Bull. Am. Ceram. Soc. 57, 186-190 (1978).

8. J. E. Ritter, Jr., J. M. Sullivan, Jr., and K. Jakus, "Application of Fracture Mechanics Theory to Fatigue Failure of Optical Glass Fibers," J. Appl. Phys., 49, 4779-82 (1978).

9. D. G. Greene, J. E. Ritter, Jr. and F. F. Lange, "Evaluation of Proof Testing as a Means of Assuring Mission Success for the Space Shuttle Thermal Protection System," Material and Process Application-Land, Sea, Air, Space, Vol. 26, Science of Advanced Materials and Process Engineering Series, pp 257-269, (1981).

10. D. G. Greene, J. E. Ritter, Jr. and F. F. Lange, "Fracture Behavior of Low Density Fibrous Ceramic, J. Am. Ceram. Soc., to be published.

11. J. E. Ritter, Jr., "Assessment of the Reliability of Ceramics," this volume.

12. S. W. Freiman, B. J. Hockey and S. M. Wiederhorn, "Allowable Residual Stress for Ceramic Chip Capacitors," Presented at the 83 Annual Meeting of the American Ceramic Society, Washington, D.C., May 3-6, 1981. 
13. R. Badaliance, D. A. Krohn and D. P. H. Hasselman, J. Am. Ceram. Soc., 57, 432-36 (1974).

14. A. W. Ruff and S. M. Wiederhorn, "Erosion by Solid Particle Impact," pp 69-126 in Treatise on Materials Science and Technology, Vol. 16: Wear, C. M. Preece, ed. Academic Press, New York (1979).

15. R. W. Rice, S. W. Freiman, and J. J. Mecholsky, Jr., "Fracture Sources in $\mathrm{Si}_{3} \mathrm{~N}_{4}$ and SiC," pp 665 in Proceedings of the 1977 DARPA/NAVUSEA Ceramic Gas Turbine Demonstration Engine, J. W. Fairbanks and R. W. Rice, Eds., Metal and Ceramics Information Center Report MCIC-78-36, Battelle Columbus Laboratories, Columbus, Ohio (1978).

16. S. W. Freiman, C. Cm. Wu, K. R. McKinney, and W. J. McDonough, "Effect of Oxidation on the Room Temperature Strength of $\mathrm{Si}_{3} \mathrm{~N}_{4}$ Hot Pressed with $\mathrm{MgO}$ or $\mathrm{ZrO}^{\prime \prime}, \mathrm{pp}$ 655-663 in ref. 15.

17. D. W. Richerson and T. M. Yonushonis, "Environmental Effects on the Strength of Silicon-Nitride Materials," pp. 247-71 in ref. 15.

18. S. W. Freiman, A. Williams, J. J. Mecholsky and R. W. Rice, "Fracture of $\mathrm{Si}_{3} \mathrm{~N}_{4}$ and SiC", pp 824-34 in Ceramic Microstructures 3,46, R. M. Fulrath and J.A. Pask, Eds., Westview Press, Boulder, Colo. (1977).

19. S. W. Freiman, J. J. Mecholsky, W. J. McDonough, and R. W. Rice, "Effects of Oxidation on the Room Temperature Strength of Hot-Pressed $\mathrm{Si}_{3} \mathrm{~N}_{4}-\mathrm{MgO}$ and $\mathrm{Si}_{3} \mathrm{~N}_{4}-\mathrm{ZrO}{ }_{2}$," pp 1069-76 in Ceramics for High Performance Applications-II J. J. Burke, E. M. Lenoe, and R. N. Katz, Brook Hill Publishing Co., Chestnut Hill, MA. (1978).

20. S. M. Wiederhorn and N. J. Tighe, "Proof-Testing of Hot-Pressed Silicon Nitride", J. Mat. Sci. 13, 1781-93 (1978).

21. D. Cubicciotti and K. H. Lau, "Kinetics of Oxidation of Hot-Pressed Silicon Nitride Containing Magnesia," J. Am. Ceram. Soc., 61 512-7 (1978).

22. D. D. Cubicciotti, R. L. Jones, K. H. Lau, and D. J. Rowcliffe, "High Temperature Oxidation and Mechanical Properties of Silicon Nitride," Interim Scientific Report 5522-2, Nov. 15, 1978, Prepared for Air Force Office of Scientific Research/NE, SRI International.

23. T. M. Yonushonis and D. W. Richerson, "Strength of ReactionBonded Silicon Nitride," pp 219-233 in ref. 15.

24. A. F. McLean, E. A. Risher, R. J. Bratton and D. G. Miller, pp 133-134 in Brittle Materials Design, High Temperature Gas Turbine, Technical Report AMMRC CTR 75-28 to the Army Materials and Mechanics Research Center, Watertown, MA., October 1975.

25. J. A. Rubin, "Probable Causes of Pitting in Hot-Pressed $\mathrm{Si}_{3} \mathrm{~N}_{4}$ Ceramics," pp 739-743 in ref. 15.

26. F. F. Lange, "Evidence for Cavitation in Crack Growth", J. Am. Ceram. Soc. 62, 222-3 (1979). 
27. N. J. Tighe, "Structure of Slow Crack Interfaces in Silicon Nitride," J. Mater. Sci. 13, 1455-63 (1978).

28. F. F. Lange, "Silicon Nitride polyphase systems: fabrication, microstructure, and properties," International Metals Reviews, 1980, No. 1 .

29. K. C. Kapur and L. R. Lamberson, "Reliability in Engineering Design," John Wiley and Sons, New York (1977).

30. N. R. Mann, R. E. Shafer and N. D. Singpurwalla, "Methods for Statistical Analysis of Reliability Data," John Wiley and Sons, New York (1974).

31. R. Schatz, M. Shooman and L. Shaw, "Application of Time Dependent Stress-Strength Models of Non-Electrical and Electrical Systems," Proceedings Reliability and Maintainability Symposium, January 1974, pp 540-47.

32. J. E. Ritter, Jr., N. Bandyopadhyay, and K. Jakus, "Statistical Reproducibility of the Crack Propagation Parameter $\mathrm{N}$ in Dynamic Fatigue Tests," J. Am. Ceram. Soc., 62, 542-543 (1979).

33. J. E. Ritter, Jr., N. Bandyopadhyay and K. Jakus, "Statistical Reproducibility of the Dynamic and Static Fatigue Experiments", Bull. Am. Ceram. Soc., to be published.

34. E. R. Fuller, Jr., S. M. Wiederhorn, J. E. Ritter, Jr., and P. B. Oates, "Proof-Testing of Ceramics: Part 2 Theory", J. Mat. Sci. 15, 2282-2295 (1980).

35. A. G. Evans, "Nondestructive Failure Prediction in Ceramics," PP 19-1 to 19-20 in Ceramics for Turbine Engine Applications, Advisory Group for Aerospace Research and Development (AGARD) Conference Proceedings No. 276, North Atlantic Treaty Organization, 7 Rue Ancelle 92200, Neuilly Sur Seine, France (1979).

36. J. M. Richardson and A. G. Evans, "Accept/Reject Decisions and Failure Prediction for Structural Ceramics: Application to Failure from Voids," J. Nondestructive Evaluation, 1, 37-52 (1980).

37. A. G. Evans, M. E. Meyer, K. W. Fertig, B. I. Davis, and H. R. Baumgartner, "Probabilistic Models for Defect Initiated Fracture in Ceramics," J. Nondestructive Evaluation, 1 , 111-122 (1980).

38. B. T. Khuri-Yakub, A. G. Evans, and G. S. Kino, "Acoustic Surface Wave Measurements of Surface Cracks in Ceramics," J. Am. Ceram. Soc. 63, 65-71 (1980).

39. J. J. W. Tien, B. T. Khuri-Yakub, G. S. Kino, D. B. Marshall and A. G. Evans, "Surface Acoustic Wave Meașurements of Surface Cracks in Ceramics," J. Appl. Physics, to be published.

40. S. M. Wiederhorn, E. R. Fuller, Jr., J. Mandel, and A. G. Evans, "An Error Analysis of Failure Prediction Techniques Derived from Fracture Mechanics," J. Am. Ceramic Soc. 59 403-11 (1976). 
41. N. R. Mann, K. W. Fertig and E. M. Scheuer, "Confidence and Tolerance Bounds and a New Goodness-of-Fit Test for TwoParameter Weibull or Extreme-Value Distribution (With Tables for Censored Sample of Size 3 (1125) )'; Aerospace Research Laboratories, Wright-Patterson Air Force Base, Ohio, ARL-71-0077, Contract No. F33(615)-70-C-1216, May 1971.

42. K. Jakus, J. P. Fahey, and J. E. Ritter, Jr., "Improving the Reliability of Hot-Pressed $\mathrm{Si}_{3} \mathrm{~N}_{4}$ Components," This volume.

43. M. F. Ashby, Acta. Met. 20, $887-97^{4}$ (1972).

44. T. A. Michalske, "The Stress Corrosion Limit: Its Measurement and Implications," This volume.

45. B. S. B. Karunaratne and M. H. Lewis, "High Temperature Fracture and Diffusional Deformation Mechanisms in Si-Al0-N Ceramics," J. Mat. Sci. 15 449-462 (1980).

46. C. A. Johnson, "Fracture Statistics in Design and Application," General Electric Report No. 79CRD212 December 1979, also see "Fracture Statistics of Multiple Flaw Distributions," this volume.

47. A. G. Evans and A. Rana, "High Temperature Failure Mechanisms in Ceramics," Acta Met. 28 129-141 (1980).

48. N. J. Tighe and S. M. Wiederhorn, "Effects of Oxidation on the Reliability of $\mathrm{Si}_{3} \mathrm{~N}_{4}$ ", This volume.

49. J. E. Ritter, Jr., P. B. ${ }^{3}$ oates, E. R. Fuller, Jr. and S. M. Wiederhorn, Proof Testing of Ceramics: Part I Experimental", J. Mat. Sci. 15 2275-81 (1980). 
EFFECTS OF EXPOSURE ON THE RELIABILITY OF SILICON NITRIDE

\author{
Nancy J. Tighe and Sheldon M. Wiederhorn \\ National Bureau of Standards \\ Washington, DC 20234
}

ABSTRACT

Oxidation at $1200{ }^{\circ} \mathrm{C}$ affects the strength and reliability of hot-pressed, magnesia-doped silicon nitride by modifying the flaw population. Static load data, and microstructural examination are used to identify the new flaw populations and to describe the failure mechanisms. The analysis is displayed graphically by means of a strength degradation map which delineates specific regions for the failures due to pit formation, crack growth, cavitation, and creep rupture.

\title{
INTRODUCTION
}

In order to use silicon nitride effectively as a structural material in high temperature applications, it is essential to have a means of assuring its reliability under stress. It is well known that oxidation in air at $1200{ }^{\circ} \mathrm{C}[1,2]$ affects the strength and reliability of the material by modifying the flaw population through thermally activated processes and chemical reactions [3, 4]. At room temperature, the strength of hot-pressed silicon nitride is determined primarily by surface flaws introduced during machining and finishing operations. At high temperatures, these machining flaws are modified by generalized corrosion of the surface due to oxidation and by strain relaxation as a result of annealing. New flaws are generated by processes of localized corrosion which cause pitting and cavitation, near the surface, and by creep which causes cavitation and crack growth. The strength of hot-pressed silicon nitride is observed to increase during the initial stage of high temperature exposure as a result of flaw 

healing and strain relaxation. However, after long periods of exposure the strength decreases as a result of the new flaws.

Techniques of lifetime prediction proposed during the past ten years are based on the assumption that fracture in ceramic materials originates from pre-existing flaws $[4,5,6]$. Strength is defined in terms of flaw size using the Griffith equation:

$$
s=K / y \sqrt{a}
$$

where $S$ is the strength, $K$ is the stress intensity factor and $a$ is the flaw size. The flaw size is defined usually in terms of an equivalent penny-shaped crack. The use of fracture mechanics theory provides a basis for predicting the effect of such flaws on the strength and on the lifetime of ceramics that are subjected to mechanical stress. The failure time can be predicted once the size of the flaw and the resistance of the material to fracture have been determined.

Proof testing and non-destructive evaluation techniques have been used to predict the reliability of components in structural applications. With these techniques,-components with flaws larger than the minimum size required for a desired engineering stress level are removed from the population. The remaining components are expected to have the predicted lifetime.

\section{Proof Test Evaluation}

Extensive experiments were carried out to determine the validity of proof-testing as a means of assuring reliability of hot-pressed silicon nitride at $120{ }^{\circ} \mathrm{C}[3,8]$. A proof test should truncate a strength distribution by breaking all specimens below a desired stress level. Surviving specimens should not break below this stress level. For our proof test experiments, an inicial strength distribution was obtained for as-machined test bars. From this initial distribution a stress was selected that would break $~ 50$ percent of the specimens on application of the load. This stress was applied to a second set of machined test bars and the survivors of this proof test were then broken. The survivors of a third set of specimens subjected to a proof stress were broken after different times of exposure at $1200^{\circ} \mathrm{C}$. It was found that the proof test truncated the strength distribution of the survivors effectively only when the survivors were broken at room temperature without a $1200{ }^{\circ} \mathrm{C}$ exposure. The data for one billet of hot-pressed silicon nitride are plotted in Fig. 1. The calculated distribution for survivors is drawn as a curved line in each plot. In this figure the strength is represented as ordered distributions plotted on Weibull diagrams [9] whereby the cumulative failure probability, $P$, is plotted as a function of the 

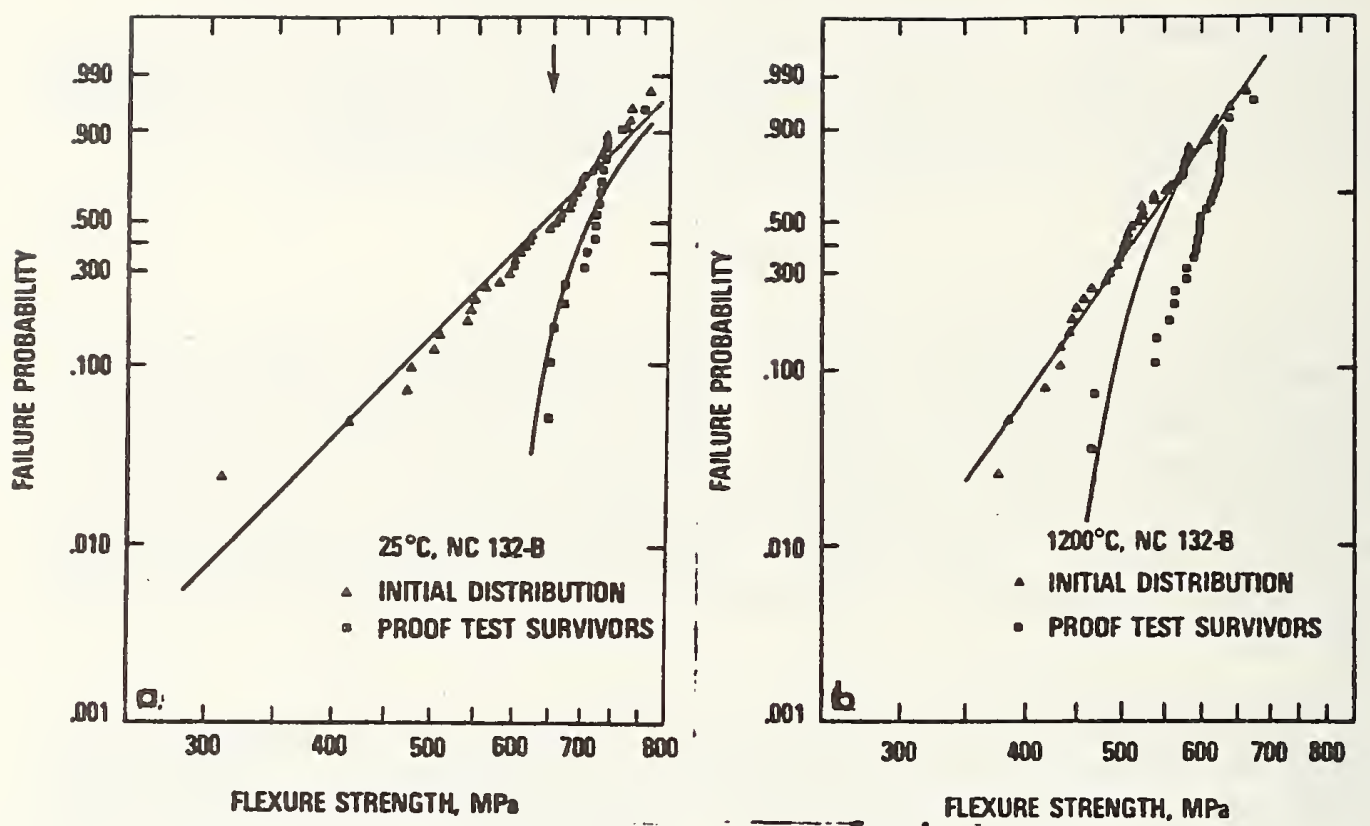

Fig. 1. Effect of proof-testing and high temperature exposure on the strength distribution of hot-pressed silicon nitride. Solid curve gives theoretical strength distribution after proof testing, arrow indicates proof stress. (a) distribution for as-machined specimens and proof test survivors; (b) distributions for asmachined and proof test survivors after $\frac{1}{2}$-hour of exposure at $1200{ }^{\circ} \mathrm{C}$. Ref. [3].

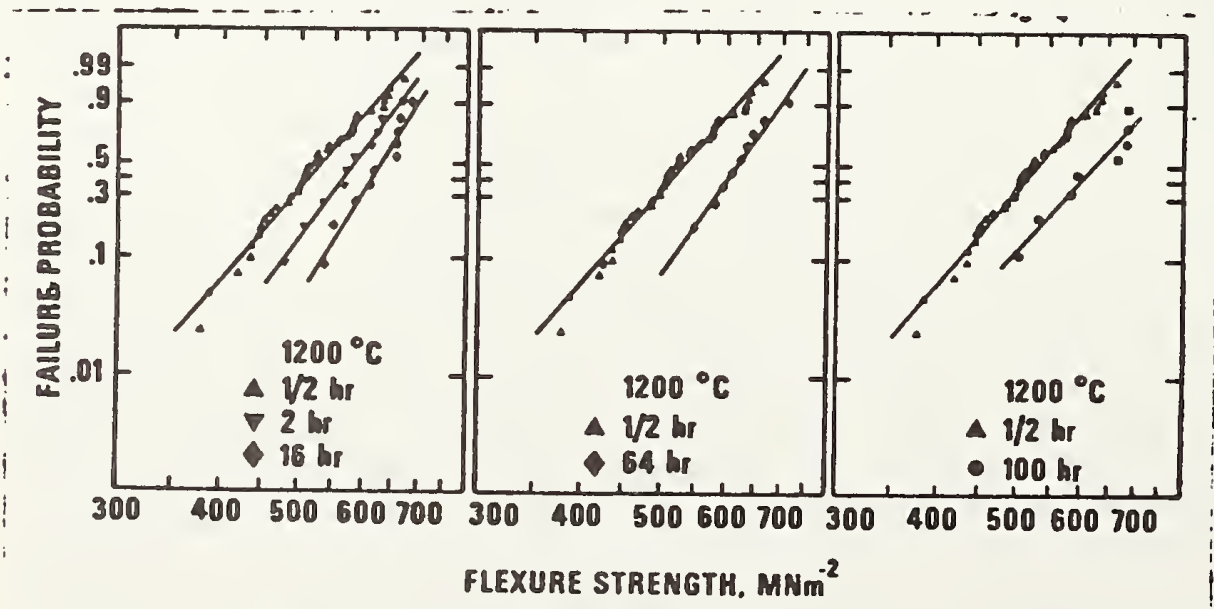

Fig. 2. Effect of heating in air at $1200{ }^{\circ} \mathrm{C}$ on the strengths of hot-pressed, magnesia-doped silicon nitride, (billet $B$ ) as measured by breaking specimens at temperature after given time periods [3]. 
strength, S. When a straight line is obtained for the distribution the slope, $m$, and the intercept, $S_{0}$, can be determined from a linear regression analysis of the experimental data as fitted to the equation:

$$
\ln \ln (1-P)^{-1}=m \ln \left(S / S_{0}\right) \text {. }
$$

Results such as those in Fig. I demonstrate conclusively that the flaw population which defined the initial as-machined strength distribution had changed between the time of application of the proof load and the application of the final stress after heating at $1200{ }^{\circ} \mathrm{C}$ for even 30 minutes. Because the flaw population was changed, lifetime predictions based on an "inert" or initial strength would have been in error. Therefore, the proof test as described represents an unreliable assurance test for silicon nitride for $1200{ }^{\circ} \mathrm{C}$ service exposures. It is clear also that a nondestructive evaluation based on an initial flaw population would have similar consequences for lifetime assurance.

\section{Flaw Population in Silicon Nitride}

The flaws identified in silicon nitride test bars can be categorized into an initial population in the as-machined specimens; and, a modified population in the specimens exposed at $1200{ }^{\circ} \mathrm{C}$. The initial population consists of cracks and strained grains resulting from the machining process, as well as inclusions and porosity resulting from the billet fabrication process. The modified flaw population depends on the exposure conditions. The inert flaw population can be modified during $1200{ }^{\circ} \mathrm{C}$ exposure by: (1) annealing of the strained surface, (2) oxidation at the surface and near-surface, (3) diffusion of impurity elements and oxygen in the binder phase, the grain boundary phase and the inclusions, and (4) thermal stresses produced by thermal expansion anisotropy in the oxide scale and in the internal oxide and nonoxide inclusions.

Examples of the changes in strength observed for silicon nitride after $1200^{\circ} \mathrm{C}$ exposure during the course of our proof testing program are shown in Fig. 2. It is apparent from these diagrams that the strength distributions for billet $B$ shifted toward higher strengths, but that after 64 hours the distributions stayed constant or dropped marginally. Examination of the surface showed extensive pitting and the traces of machining damage were gone. Thus a new flaw population had been generated.

In order to predict the reliability of silicon nitride, it is necessary to obtain experimental data showing the strength changes that occur during oxidation as a function of both time and stress. The Weibull type representation of strength is not adapted easily 
to the prediction of strength as a function of time because as shown in Fig. 2 a series of diagrams is needed to represent the strength at given time intervals; and, there is no clear functional relationship between the separate diagrams except that both $\mathrm{S}_{0}$ and $m$ changed with time.

Clearly, the development of a diagram that represents the time evolution of a Weibull type distribution would be of value for the design of ceramic structural components. The strength degradation map discussed in another paper in this volume [10] is such a diagram. This map relates the strength, the failure time, and the failure probability to the mechanism of failure. This type of representation is similar in principle to the deformation maps suggested by Ashby [11]. The development of our maps was based on the observations of the changing flaw population identified in silicon nitride. Strength data obtained from static load experiments at $1200{ }^{\circ} \mathrm{C}$ for different times and applied stresses were used to develop the map, and are presented in this paper. The validity of the strength degradation map is demonstrated by identifying specific mechanisms of failure in regions on the diagram.

\section{EXPERIMENTAL PROCEDURE}

\section{Materials and Procedures}

Static load data were obtained from one billet of hot-pressed magnesia-doped silicon nitride designated NC 132 billet C. Specimens were machined from the billet by diamond sawing and were ground to final size using a 180 grit diamond wheel. Specimens were ground along their length and the edges were retained. Each specimen was given a number according to its location in the billet from which it was taken. The numbers were randomized before testing to avoid systematic errors resulting from nonhomogeneous billets or systematic variations in the cutting procedure. Three hundred and fifty specimens $(3 \times 4 \times 50 \mathrm{~mm})$ were cut from the hot-pressed billet which was manufactured from powder lot HN8 having the following analysis: $93.3 \% \mathrm{Si}_{3} \mathrm{~N}_{4} ; 0.14 \% \mathrm{Al}_{2} \mathrm{O}_{3}$; $0.04 \% \mathrm{Ca} ; 0.36 \% \mathrm{Fe} ; 1.34 \% 0 ; 3.4 \% \mathrm{~W}$. Billet $\mathrm{B}$ (shown in Fig. 2) was from the same powder lot.

Al] bars were tested in four-point bending in air at a temperature of $1200{ }^{\circ} \mathrm{C}$. Bend fixtures were made of silicon carbide and had upper and lower spans of $10 \mathrm{~mm}$ and $40 \mathrm{~mm}$, respectively. Selection of test temperature was based on our previous studies [3] which indicated that the onset plasticity and crack growth occurred near $1200{ }^{\circ} \mathrm{C}$ in hot-pressed materials. Hence it was our opinion that $1200{ }^{\circ} \mathrm{C}$ was still a reasonable maximum service temperature for these materials. Static fatigue tests were carried 
out according to the following scheme: $\sim 2 \mathrm{~kg}$ was applied to hold the specimens in place; the furnace temperature was raised at the rate of $\sim 20^{\circ}$ per minute until the final temperature, $1200^{\circ} \mathrm{C}$, was attained; then, the specimens were equilibrated at $1200{ }^{\circ} \mathrm{C}$ for $\frac{1}{2}-$ hour. After equilibration, specimens were loaded to the desired stress then soaked at temperature for times that ranged from $\frac{3}{2}-$ hour to 1000 hours. A record was kept of the time of fracture of all specimens that broke during the soak period. After soaking at temperature for the requisite period of time, specimens were fractured (without cooling to room temperature), using a relatively rapid stressing rate. Strengths were measured also at room temperature to serve as a basis of comparison for the high temperature results. Specimens were marked according to their position in the furnace so that the pieces could be reconstructed after fracture.

\section{Test Facility}

Because of the large number of specimens tested and the long periods of time required for testing, standard universal testing machines were inadequate for the present study. Therefore, it was necessary to design a test facility in which a large number of specimens could be tested simuitaneousiy, and which was relatively inexpensive. The test facility developed for this study is shown in Fig. 3. The system used pneumatic bellows to apply the load to the specimens and an electronic load cell to measure the load. The bellows employed a rolling diaphram which was almost friction free; the force required to move the bellows at zero pressure was $\sim 3 \mathrm{~N}$. The bellows and the load cell were attached to a heavy steel load frame and the load was applied to the four-point bend fixture via silicon carbide rods. The furnace used MoSi, elements and was capable of achieving $1600{ }^{\circ} \mathrm{C}$. By monitoring the ${ }^{2}$ load as a function of time, we determined that the load on each specimen could be held constant to $\sim 1$ percent of the maximum load. At the end of the test period specimens were broken by increasing the air pressure to the bellows.

Because of the compact nature of the load train, three specimens could be tested in each furnace. During the development of the test facility, we were concerned that the shock of one specimen breaking during the soaking period would trigger other breakage within a furnace. However, among the dozens of specimens that broke during the soak period we never observed this type of breakage. Apparently, the pneumatic bellows were able to absorb the shock of fracture without transmitting it to the unbroken specimens. Thus, the problem of multiple breakage that could occur when a constant direct weight is employed to stress specimens did not occur when pneumatic loading was employed. 

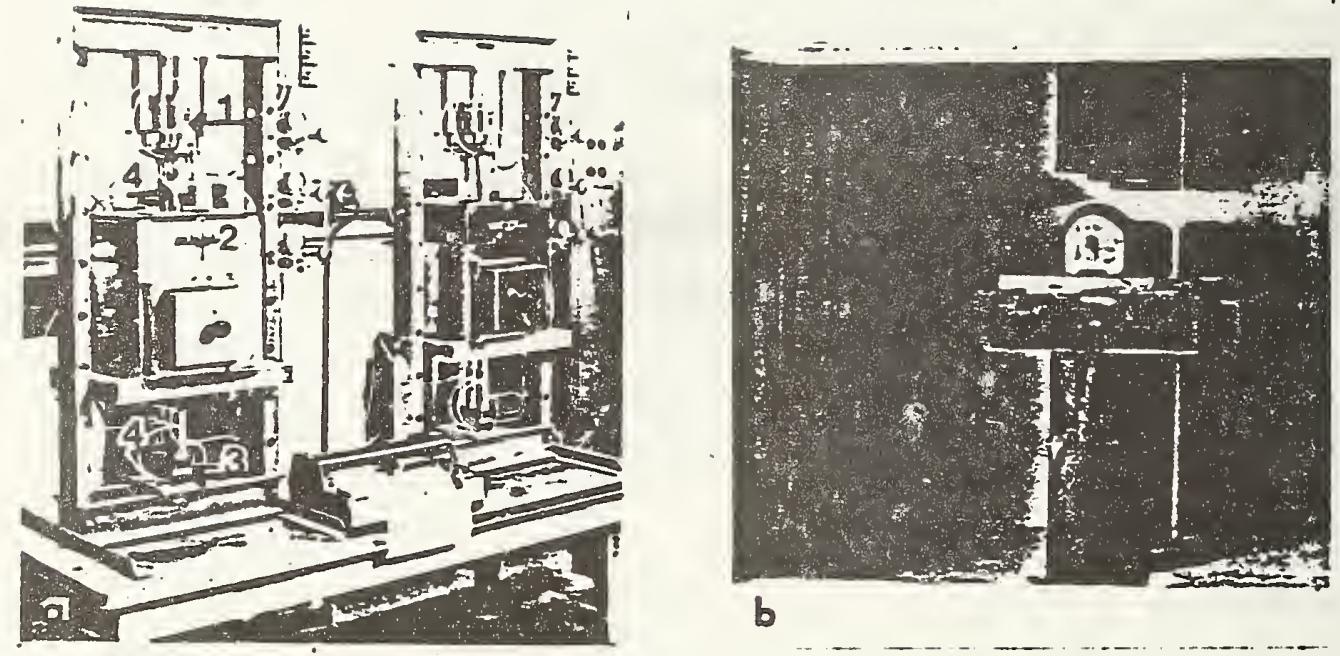

Fig. 3. Facility for carrying out high temperature static fatigue tests showing positions of (1) pneumatic cylinders, (2) furnace, (3) load cellis, and (4) water cooled rod holders. Micrograph b shows the interior of the furnace with the specimens in place.
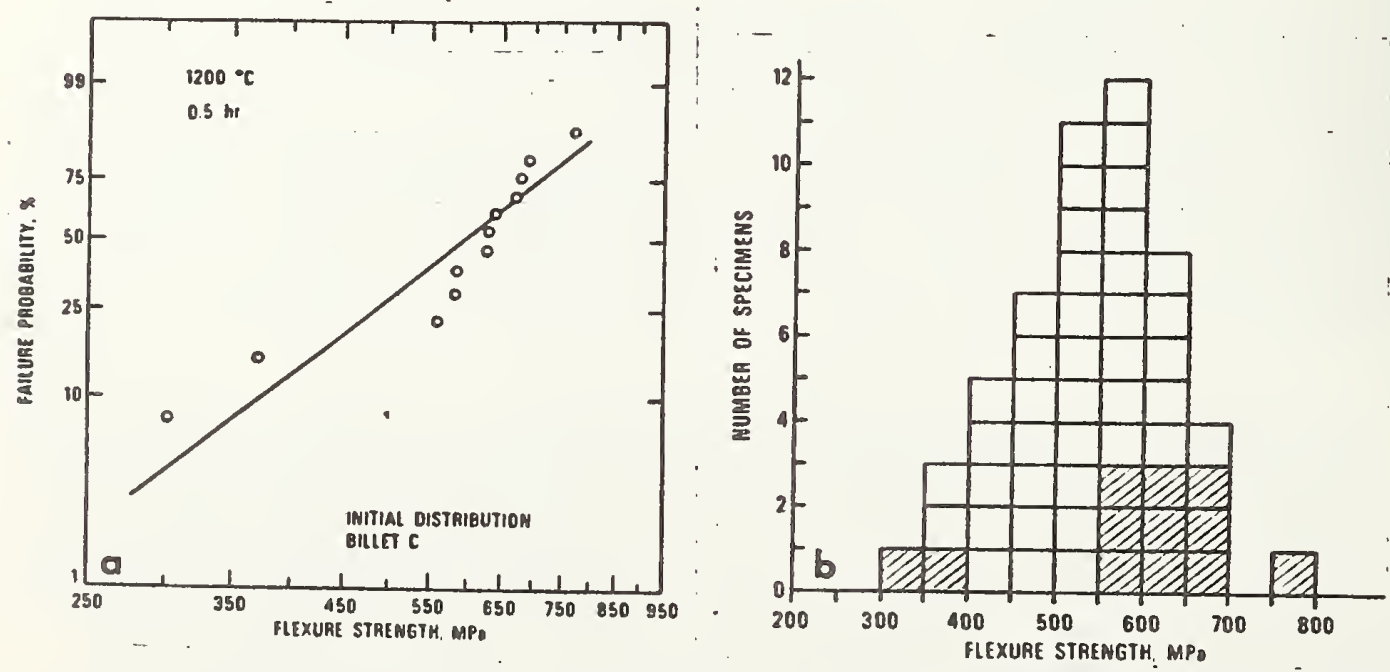

Fig. 4. Strength distribution for the as-machined silicon nitride specimens (a) Weibull plot for billet $C$, (b) histogram including specimens from billet $B$ and billet $C$ (shaded). 
We measured the deflection on some of the specimens initially by attaching a dial-gauge to the silicon carbide push rod, and measuring the displacement rate of the rod relative to the test frame. Direct tests of creep on the SiC push rods indicated that the rods did not creep at $1200{ }^{\circ} \mathrm{C}$. At a later time, linear variable differential transformers (LVDT) were mounted in each load train and the specimen deflection was measured continuously over the 1000 hour test periods. The creep measurements obtained from the dial gauges and from the LVDTs were consistent with the deflections measured on unbroken specimens that were removed from the test facility after specified soak periods.

\section{RESULTS}

\section{Static Load Data}

The stress levels for the static load tests were chosen by considering the strength distribution obtained after heating onehalf hour at $1200^{\circ} \mathrm{C}$; and, then selecting a range of stresses with a low probability of failure on loading. The initial strength distribution is shown in the Weibull plot of Fig. 4a. The twelve strength values for billet. " $C$ " were compared with the strength distribution obtained under the same conditions for billet "B." This combined distribution for the two billets is shown in Fig. 4b. Since the 12 strengths fell within the histogram of the 40 strengths for billet "B", it was considered unnecessary to break additional specimens for the selection of applied stress.

The results of the static load tests are summarized in Fig. 5. In order to establish a reasonable applied stress, stresses of $400,350,250$, and $200 \mathrm{MPa}$ were applied to sets of six specimens each for an initial test period of one week at $1200{ }^{\circ} \mathrm{C}$. In this figure, specimens that failed under load are indicated by the downward pointing arrows; and, the number of specimens tested at each stress is indicated in brackets on the figure. Most of the specimens that survived the required test period were broken at temperature in order to obtain the survivor distribution. In a few cases the furnace was cooled to room temperature with the surviving specimens under load either intencionally or because of a power failure.

The stress $250 \mathrm{MPa}$ was chosen for more extensive testing because at least one specimen broke within one week of soaking and therefore some failures were expected over the six week period. No failures occurred in one week with an applied stress of $200 \mathrm{MPa}$ and too many failures occurred with stresses of 350 and $400 \mathrm{MPa}$. Further, the load $250 \mathrm{MPa}$ would approximate the actual stress for structural parts. The strength distributions obtained from breaking the specimens that survived the $250 \mathrm{MPa}$ stress for specific 
time intervals are plotted in Fig. 6. The Weibull parameters and the mean strengths obtained for these sets of specimens are listed in Table I. Both presentations of the data indicate that there are changes in mean strength and in the scatter of the strength distribution in the different time periods.

It is instructive to compare the strength distributions obtained after $\frac{1}{2}$-hour without load and after 1000 hours with a stress of $250 \mathrm{MPa}$. These two distributions as shown in Fig. 7 are clearly very similar although the flaw populations have different origins. The flaw population in the 1000 hour distribution was generated during the exposure, while the flaw population for the $\frac{3}{2}$-hour distribution represents the initial distribution resulting primarily from machining damage. The straight line drawn in for the 1000 hour distribution represents the average behavior of the data. However, it is worth noting that there are two inflections in the distributions. Such inflections generally indicate that there is a mixture of flaw populations in the distribution [12]. The bulk of the strength distribution after 1000 hours lies at lower values of strength than the distribution obtained after $\frac{1}{2}-$ hour.

Table 1

Data Obtained From Static Load Tests on Hot-pressed Silicon Nitride

\begin{tabular}{lrccc}
\hline Static Stress & $\begin{array}{c}\text { Time } \\
\text { Hr. }\end{array}$ & $\begin{array}{c}\text { Strength } \\
\text { S, MPa }\end{array}$ & $\begin{array}{c}\text { Weibull Parameters } \\
\text { So, MPa }\end{array}$ & $\begin{array}{c}\text { m } \\
250 \mathrm{MPa}\end{array}$ \\
& $1 / 2$ & $678 \pm 55$ & 700 & 14.4 \\
& 2 & $681 \pm 38$ & 699 & 19.6 \\
& 4 & $682 \pm 81$ & 722 & 7.8 \\
& 16 & $709 \pm 73$ & 743 & 9.4 \\
& 64 & $742 \pm 103$ & 760 & 6.5 \\
& 168 & $691 \pm 108$ & 738 & 6.4 \\
& 330 & $683 \pm 91$ & 719 & 8.4 \\
& 1000 & $553 \pm 150$ & 578 & 3.6 \\
& $1 / 2$ & $581 \pm 126$ & 646 & 4.1 \\
& & & & \\
\hline
\end{tabular}




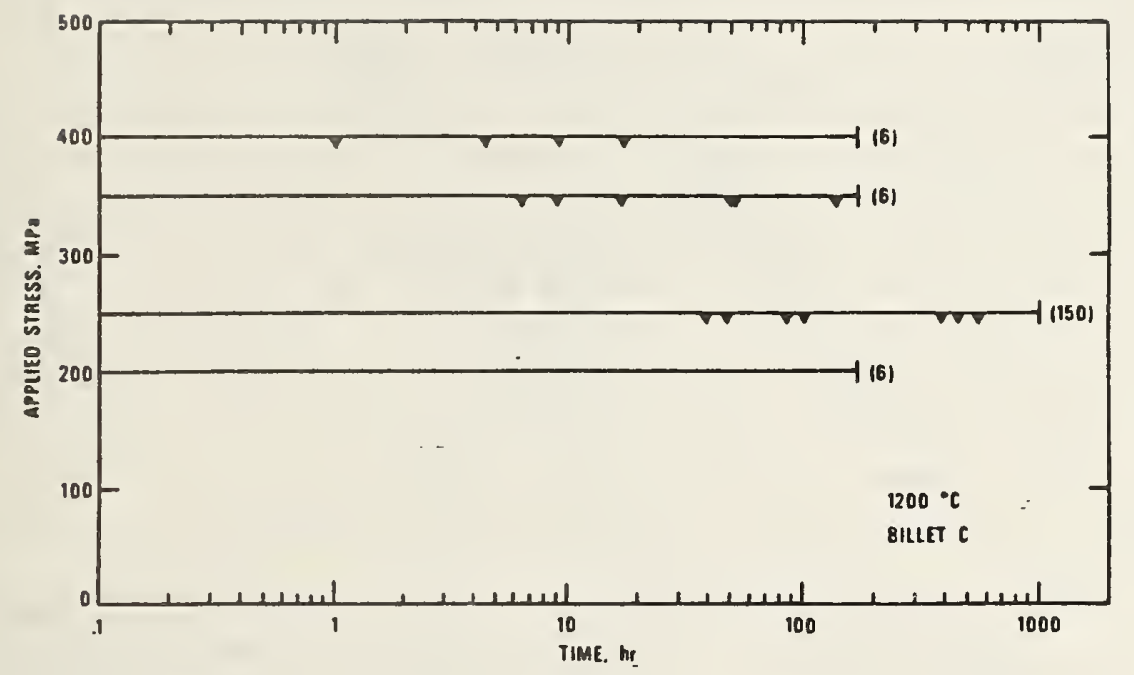

Fig. 5. Plot of applied stress vs time for hot-pressed silicon nitride billet $C$, failure times are indicated by arrows. Numbers in brackets indicate total number of specimens tested at that stress level.

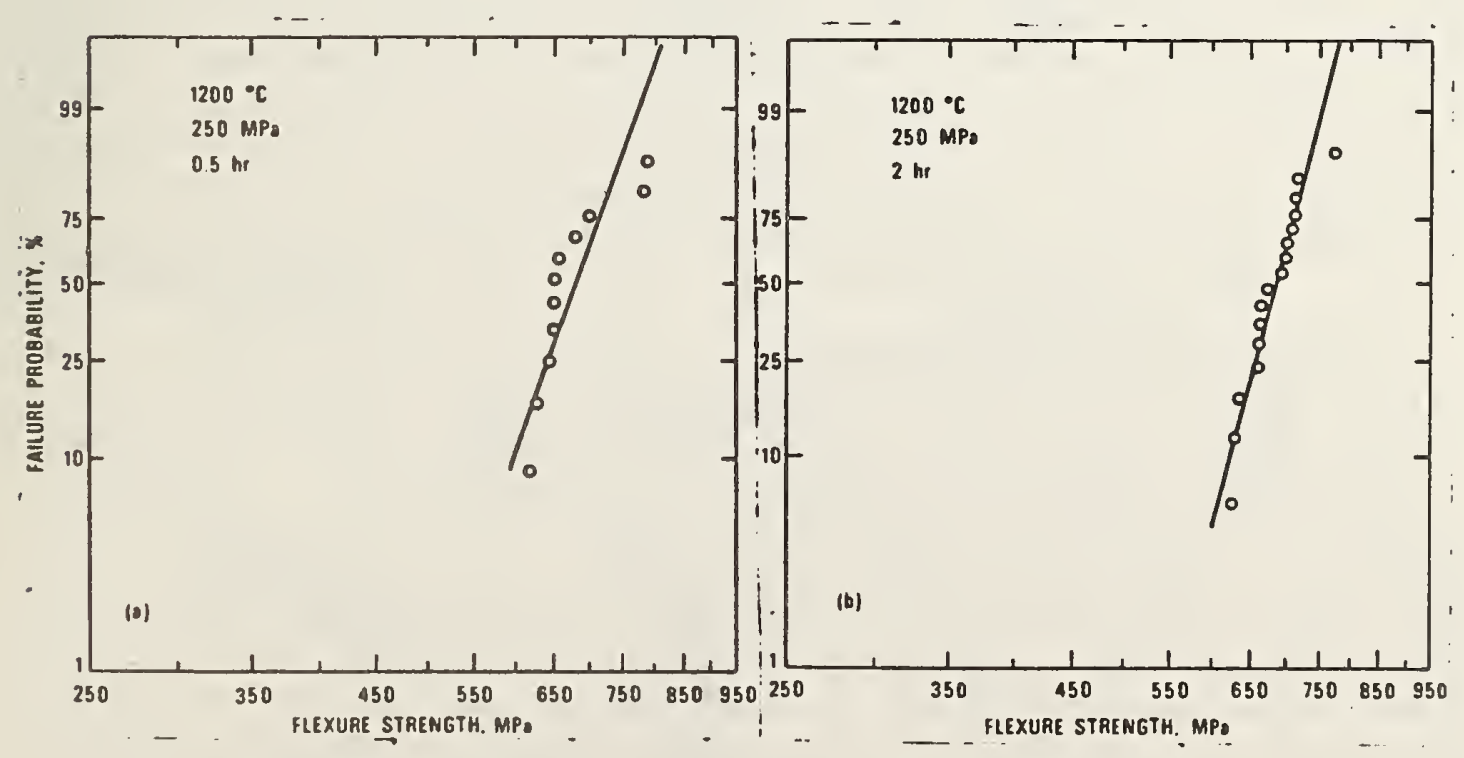

Fig. 6. Weibull plots for strength distributions obtained for hot-pressed specimens from billet $C$, after holding a static load of $250 \mathrm{MPa}$ for (a) $1 / 2$ hour, (b) 2 hours, (c) 4 hours, (d) 16 hours, (e) 64 hours, (f) 168 hours, (g) 330 hours, and (h) 1000 hours. Specimens were broken at temperature without removing the static load. 

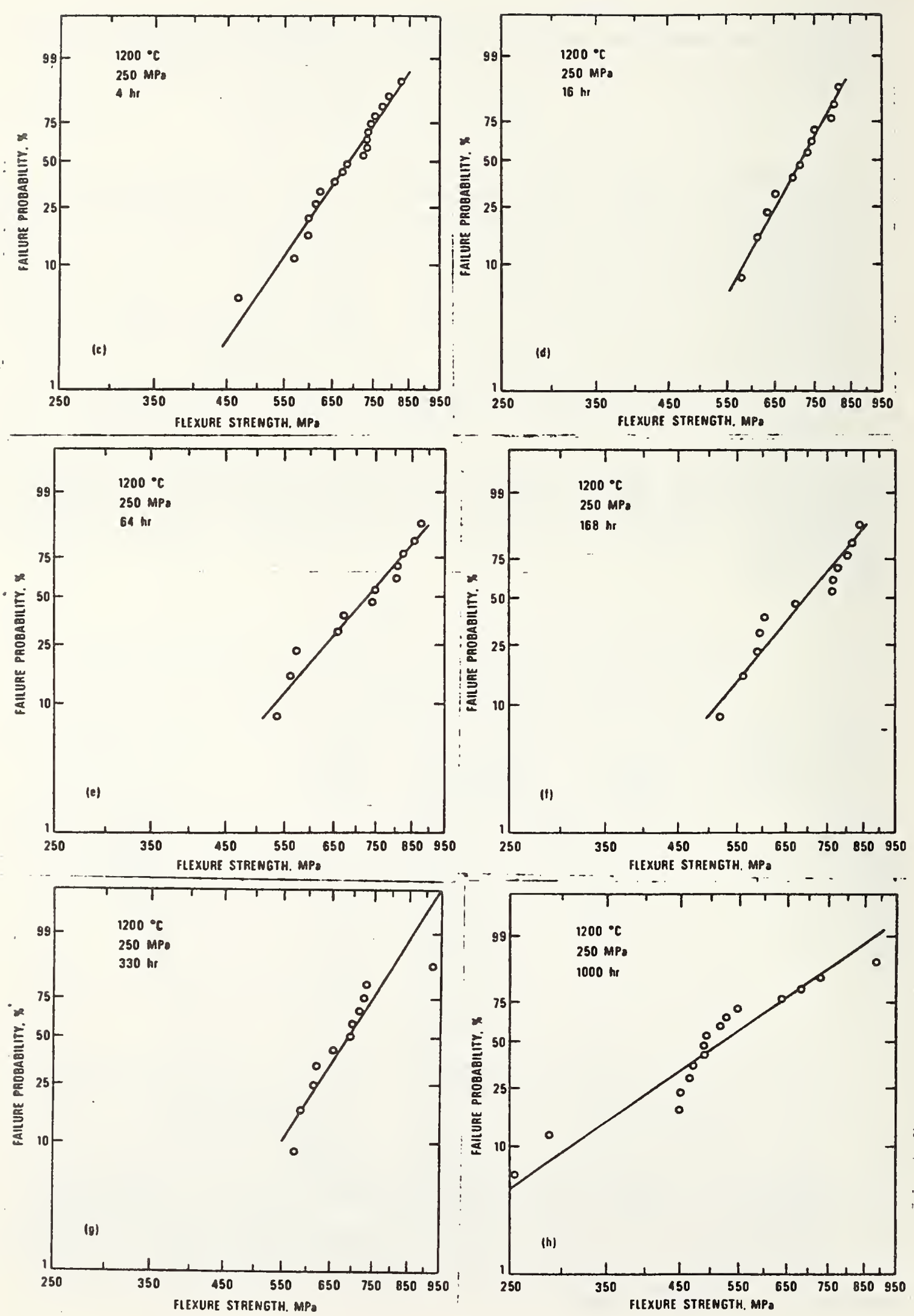
The specimens that were held under load of $250 \mathrm{MPa}$ at $1200{ }^{\circ} \mathrm{C}$ for more than a few days were noticably bent. The deflections were measured from unbroken specimens and from the deflection curves to obtain a measure of the total outer fiber strain. The creep behavior during a 1000 hour period is indicated in Fig. 8. This figure shows the curve obtained from the continuous recording of the LVDT for one specimen. Data points were plotted for one hour intervals for the first 24 hours and for 24 hour intervals for the next 41 days. It is apparent that three regimes of creep are present in the figure. Measurements of the steady state deflections in periods II and III give an average creep rate of $6.9 \times 10^{-8} / \mathrm{s}$ and $2.3 \times 10^{-6} / \mathrm{s}$ respectively. The data in region I could not be represented by a straight line because of its curvature.

\section{Microstructure and Flaw Modification}

Fracture surfaces and oxide scale surfaces were examined microscopically after the static fatigue tests in order to identify fracture origins. Unfortunately, many of the fracture origins were lost when the broken specimen impacted the silicon carbide fixture after fracture. Fragmentation of the fracture interfaces occurred and cracks parallel to the fracture interface extended across the tension surfaces for a distance of a few tenths of a $\mathrm{mm}$ from the interface. The fragmentation was noted especially in the high strength specimens. Specimens that could be reconstructed did have identifiable fracture origin tracings which indicated that fracture initiated at corners or along the tension surface. Similar fracture origins traceable to machining cracks or to oxidation pits were identified in the earlier proof test programs in which specimens were oxidized for up to 100 hours at $1200{ }^{\circ} \mathrm{C}[3]$.

Examination of the oxide scale on the specimen surfaces by light microscopy and by $X$-ray powder diffraction showed results similar to those we had observed during earlier proof test experiments [3]. A continuous film formed on specimens heated for $\frac{1}{2}-$ hour; and after 2 to 4 hours, distinct globules were distributed over the oxide scale. After 16 hours the appearance of needles indicated the presence of enstatite in the oxide scale and oxide mounds were clearly visible in the scale. These features are shown in Fig. 9. The oxide scale on the 1000 hour specimens had a grey color which resulted from oxide pillars that extended 10 to $20 \mu \mathrm{m}$ above the surface of the more compact sintered scale. When the oxide scale was removed by etching in a solution of $\mathrm{HF}+\mathrm{H}_{2} \mathrm{SO}_{4}$, pits 50 to $100 \mu \mathrm{m}$ in diameter were found distributed over the silicon nitride surface. The etched silicon nitride surfaces as shown in Fig. 9c,d, exhibit an overall roughness from the oxidation reaction which mirrors the microstructure of the oxide 


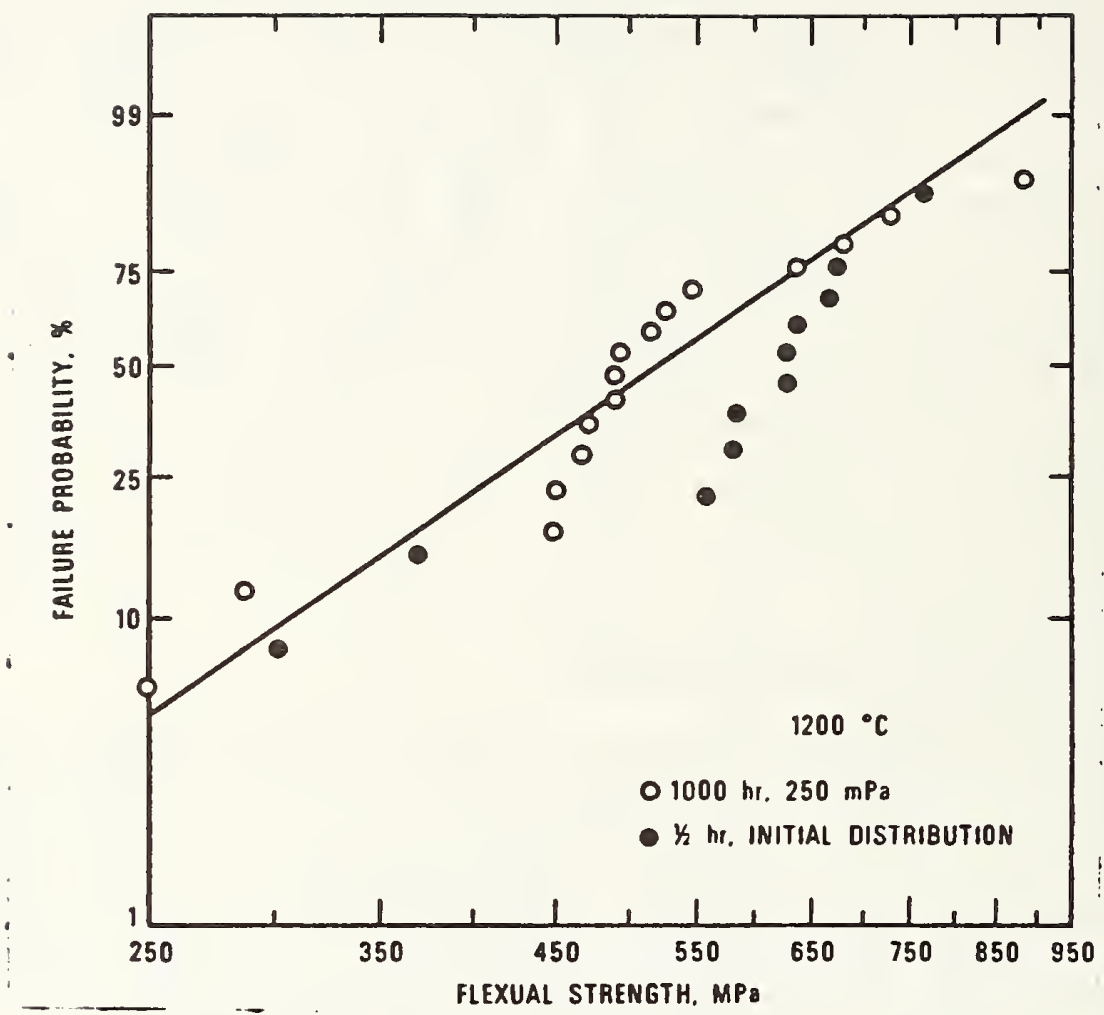

Fig. 7. Weibull plot comparing the strength distribution obtained after $\frac{1}{2}$-hour exposure without static load and after 1000 hours with a static load of $250 \mathrm{MPa}$.

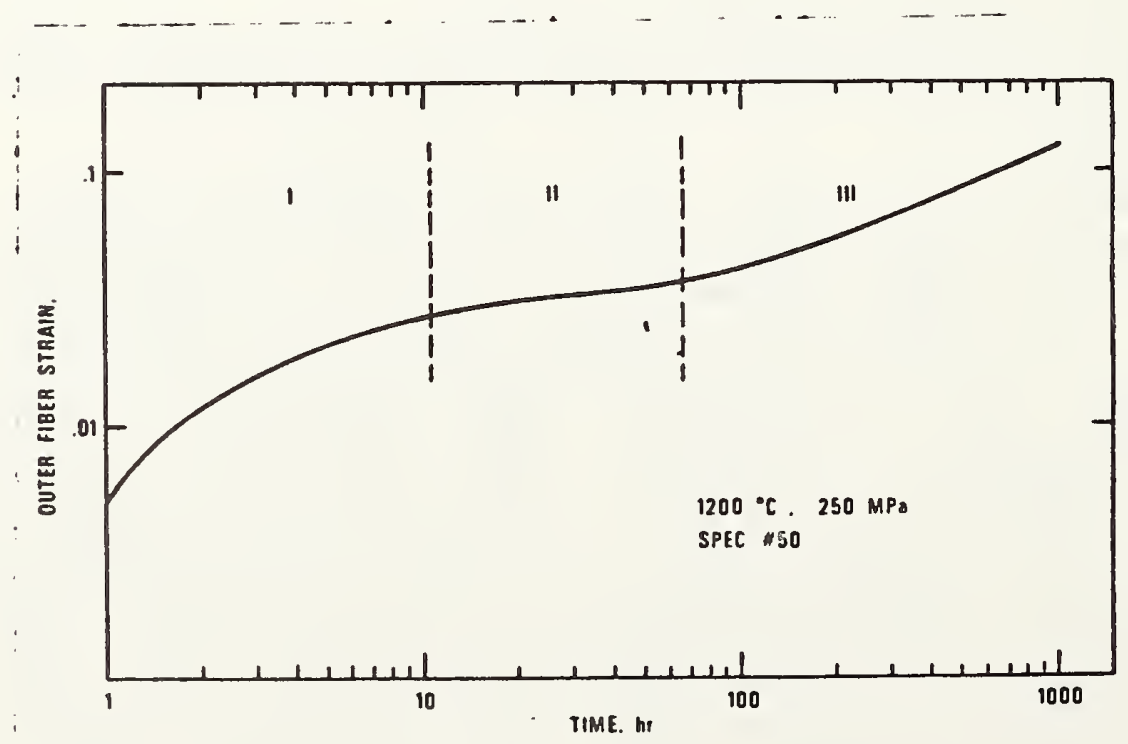

Fig. 8. Plot of the outer fiber strain obtained for one specimen and showing three regions of deflection rate change. 
scale. The microstructure of an oxide scale from a specimen from a static load test is shown in Fig. 10. The two transmission electron micrographs show upper and lower surfaces of a tapered section of the oxide scale that are separated by several microns. Figure 10 a shows a portion of the amorphous layer adjacent to the matrix and Fig. $10 b$ shows the sintered pyroxene/tridymite phases. From stereo micrographs the oxide scale in Fig. 10a appears to be composed of globules with extensive porosity throughout the phase. The amorphous diffraction pattern taken from this phase has not been identified.

Specimens that were broken after soaking for times greater than 100 hours, where it is apparent from the deflection measurements that creep was occurring, were examined by transmission electron microscopy in order to identify microstructural changes associated with deformation and failure. For this examination, sections were cut from the tension and compression surfaces and also from the transverse cross-section. The sections were mechanically and ion thinned to reveal different portions of these specimens.

Figure 11 illustrates the extent of bending and the microstructural changes associated with creep at $1200{ }^{\circ} \mathrm{C}$ at a stress of $250 \mathrm{MPa}$. The unbroken bar was cooled under load after 900 hours of exposure. The letters $b$ and $c$ correspond to the compression and tension surfaces respectively. The electron micrographs were taken from the compression and tension sides of a similar specimen that was broken after 1000 hours $(S=636 \mathrm{MPa})$. The compression side $b$ shows some cavitation at triple junctions (arrowed). The microstructure is otherwise compact with dislocation arrays, precipitates and some amorphous grain boundary phase. The microstructure of the tension side $c$ shows extensive cavitation at triple junctions and along grain boundaries, dislocation arrays within the grains; unusually large grains indicative of grain growth; and, oxide filling some of the cavitation space. The region shown in the micrograph was contained within an area $100 \mu \mathrm{m}$ in diameter that was very porous compared with its surroundings. This iype of porous region would constitute a creep generated flaw. Figure 11 thus illustrates the the extensive cavitation associated with creep in region III of the curve in Fig. 7 . It is apparent that some grain growth and grain boundary sliding occurred during the creep as expected.

\section{Strength Degradation Map}

The static load data is presented in the form of a strength degradation map in Fig. 12. Basically, the deformation map provides a means of displaying the time evolution of the strength of the silicon nitride. On this diagram the strength is plotted as 

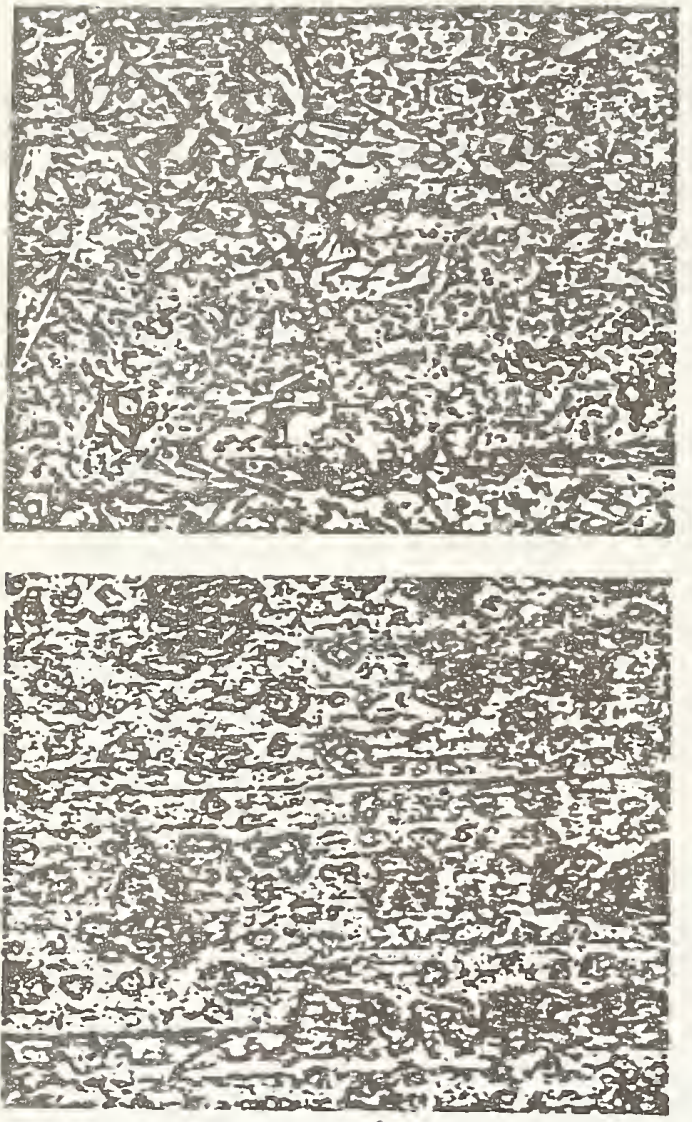
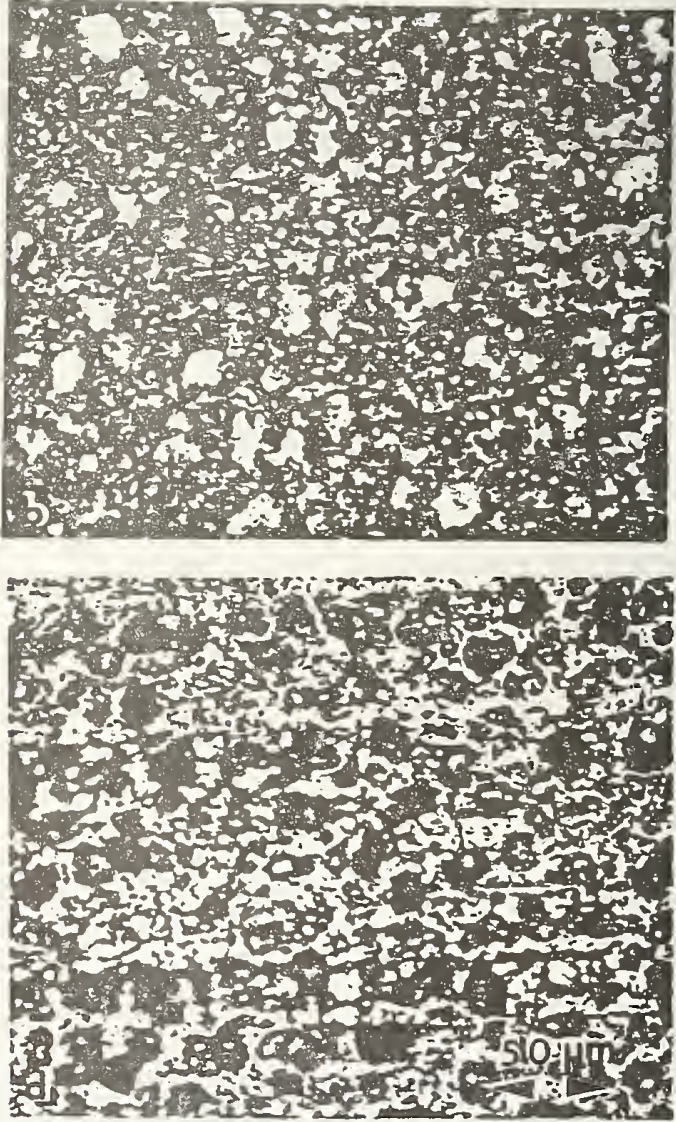

Fig. 9. Light micrographs of specimens heated $(a, c) 16$ hours and. $(b, d) 1000$ hours. Surface oxide in $a, b$ and etched surface in $c, d$.
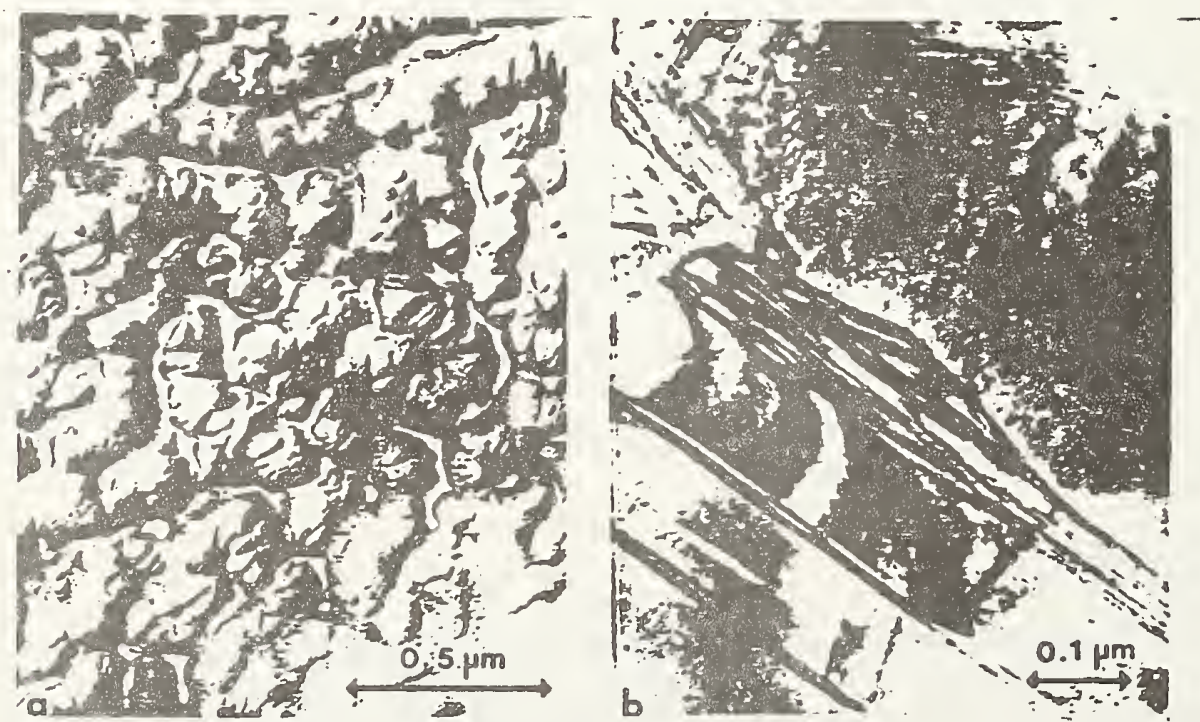

Fig. 10. Transmission electron micrographs of oxide on specimen heated 1000 hours showing (a) amorphous phase near matrix and (b) sintered silicate phase. 
the ordinate and the time of exposure to a static load is plotted as the abscissa. Lines of constant probability are plotted to indicate changes in strength as a function of time at a given probability level. The applied stress and the static fatigue limit are plotted as horizontal lines. On this diagram, a specimen fails when its strength is less than the applied stress of $250 \mathrm{MPa}$. The intersection of the constant probability curves with the applied stress line indicates the fraction of the components that are expected to break at the time given by the intersection. The static fatigue limit indicates the strength limit for sub-critical crack growth. The boundaries drawn on the upper part of the diagram indicate the dominant processes such as flaw healing, pit generation, and creep that affect the strength.

The strength degradation map in Fig. 12 was prepared by constructing lines of constant failure probability obtained directly from Weibull curves such as those shown in Fig. 6. Since each of these curves presents the failure probability as a function of strength at a particular instant in time, a series of these curves can be used to plot the relation between strength and time for a given failure probability level. Thus, the map represents the strength behavior of the hot-pressed silicon nitride specimens from billet $\mathrm{C}$ at a temperature of $1200{ }^{\circ} \mathrm{C}$ and an applied stress of $250 \mathrm{MPa}$. In cases where specimens broke during the test period the specimen was included in the populations of the Weibull distribution for the map.

Changes in the slopes and spacing of the constant failure probability lines indicate the changes in the strength distribution and determine the boundaries between the different regions. The different regions of strength behavior indicated on the map in Fig. 12 were identified and verified by microscopic examination of the specimens. At low failure probability the dominant mechanism is crack growth. The other boundaries separate regions we have identified as representing crack healing, pit formation, and cavitation creep.

\section{DISCUSSION}

The various regions of behavior indicated on the strength degradation map of Fig. 12 were determined and verified by microscopic examination of the test specimens from the present series of tests and from the earlier series of proof tests on the same material [3]. Microscopic studies of fracture origins [3,8,12-14] have shown that fracture during the initial period of exposure results from cracks introduced into specimens by machining and surface finishing. This damage consists of cracks and residual stresses due to grinding; and, the increase in strength must result, therefore, from the annealing of this surface damage. 


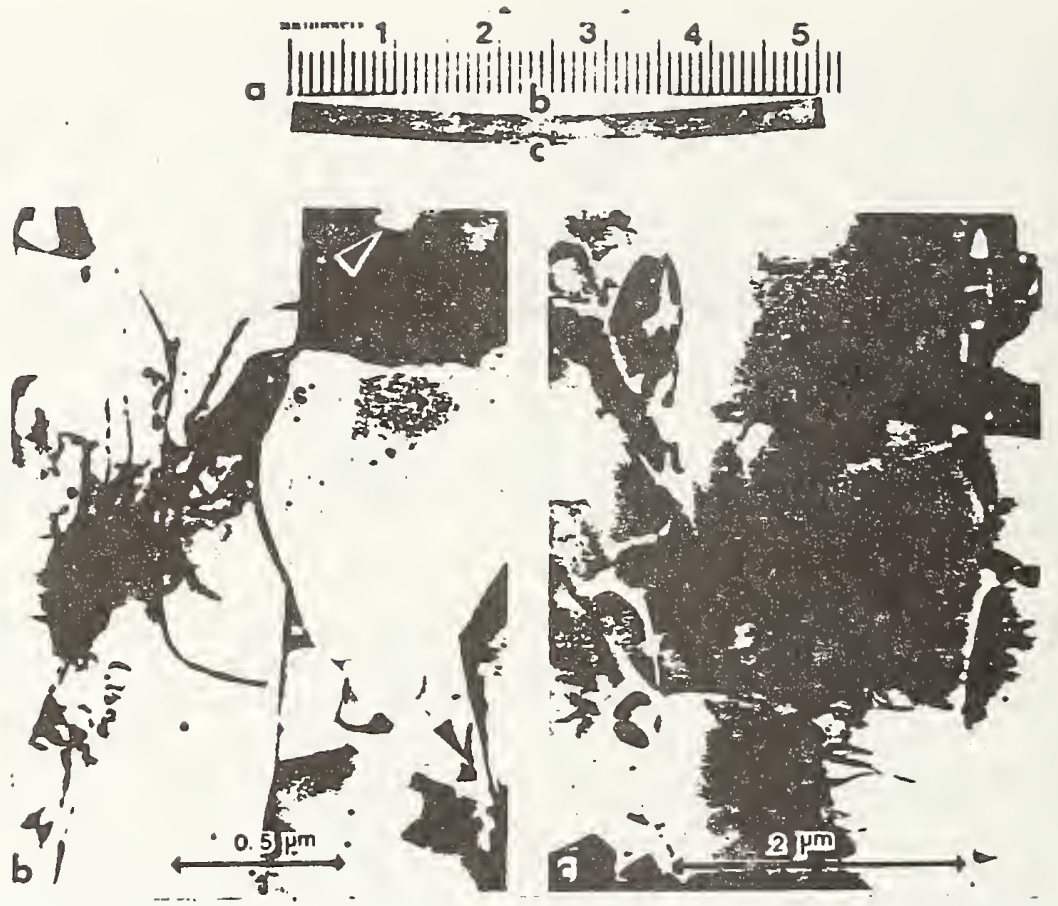

Fig. 11. (a) Light micrograph of a specimen bent during a 900 hour exposure at $1200^{\circ} \mathrm{C}$, applied stress $250 \mathrm{MPa}$; (b) cavitation and grain deformation near compression side of specimen broken after 1000 hour exposure at $1200{ }^{\circ} \mathrm{C}$, applied stress of $250 \mathrm{MPa}$; and (c) extensive cavitation near tension side.

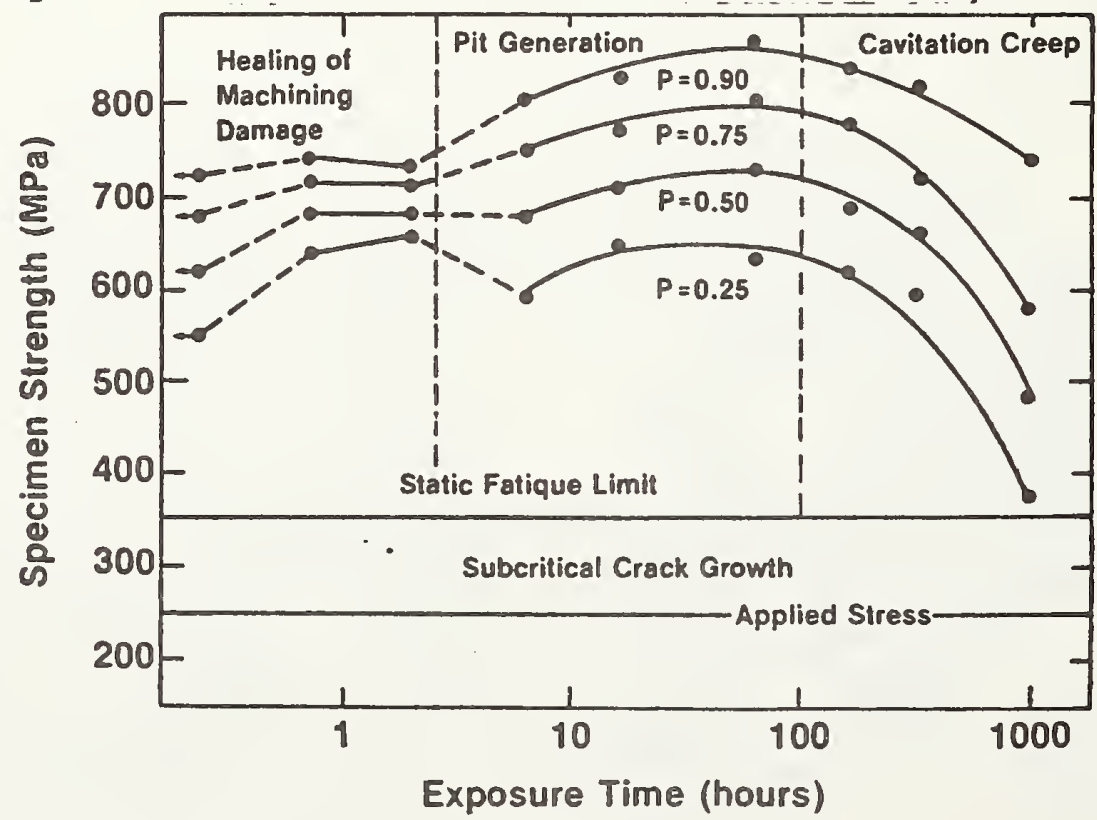

Fig. 12. Deformation map constructed from strength distribution data obtained for billet $C$ specimens that survived static load test at $1200^{\circ} \mathrm{C}$, with a load of $250 \mathrm{MPa}$. 
The sudden change in the spacing of the probability curves between 2 and 4 hours of exposure under load suggests a change in the type of flaw that causes fracture. Examination of oxidized surfaces indicate that globules of glass form a pattern after 4 hours of exposure suggesting the possibility of localized corrosion and the beginnings of pit formation at the specimen surface. This suggestion is supported by the surface analysis studies in which the glass was removed by etching and pits were found beneath the globules (Fig. 9). Earlier studies showed that these pits are sources of failure. Hence, the second region of strength control was labelled pit generation. The fact that the strengths of the bars increase after this initial formation of pits suggests that new pits are not generated continually during exposure and that some annealing of the pits occurs with continued exposure.

After an exposure time of $\sim 100$ hours, a general decrease in strength is observed for all of the probability curves. This decrease in strength is associated with our observations (Fig. 8) that the creep rate of our specimens increases after approximately 100 hours of exposure. Microscopic examination of the specimens shown in Fig. 11 indicate extensive formation of cavities at triple junctions and along grain boundaries in the regime III creep of Fig. 8. Thus, the region of decreasing strength on the strength deformation map is labeled cavitation creep. In addition to the three mechanisms of strength control just discussed, a region labeled sub-critical crack growth is indicated on Fig. 13 and a fatigue limit of $350 \mathrm{MPa}$ is assigned as an upper bound. The data shown in Fig. 7 indicate that some specimens in the sample of 150 specimens tested at $250 \mathrm{MPa}$ should have had strengths that were as low as $350 \mathrm{MPa}$. Based on the crack growth data reported by Wiederhorn and Tighe [2], the calculated failure time for $350 \mathrm{MPa}$ should have been 10 seconds. Therefore, some failures should have occurred on loading or shortly after loading the specimens if crack growth occurred. However, no failures were observed during the first $\sim 40$ hours of the test. Thus, the data suggest that at low levels of applied load subcritical crack growth is not an important failure mechanism and that the static fatigue limit is less than $350 \mathrm{MPa}$.

From the electron microscopy results it appears that creep in the 1000 hour test period resulted from grain boundary sliding associated with a viscous grain boundary phase and from cavitation at triple junctions and along grain boundaries. In addition, the grains deformed along their boundaries and grain growth and rearrangement took place. The large (> $100 \mu \mathrm{m}$ ) porous regions such as that described for Fig. 11 are potential flaw sites and the cracks that develop in these regions can grow large enough to cause failure under the constant stress. As evidenced from the $x$-ray analyses of particles on grain boundaries and of the oxide scale 
considerable diffusional changes took place in the 1000 hour specimens. The results of a more complete analysis, of the deformation microstructures will be published separately.

The static fatigue data presented in this paper demonstrate the complex behavior that can be encountered when structural ceramics are subjected to the combined effect of environmental attack and mechanical stress. For the hot-pressed silicon nitride billet studied in this paper, at least three regions of strength behavior were observed. The strength degradation map provides a convenient way of condensing this behavior onto a single diagram which displays the time dependence of strength in mechanistic terms. However, it should be recognized that relatively large sets of data are needed to define a map for each condition of engineering interest. Further a series of maps are needed to fulty define mechanical behavior as a function of applied stress and temperature. In principle, the work required to obtain such a set of maps can be reduced considerably by the development of theoretical models that describe the strength behavior in the various regions noted in Fig. 12. Such models would permit the materials engineer to concentrate on determining the constants of the model and the boundary conditions predicted for the strength degradation map. Although a start has been made in this direction [15], modeling of mechanical behavior at elevated temperatures still needs further development for application to structural design.

SUMMARY

Under constant stress conditions, during heating at $1200{ }^{\circ} \mathrm{C}$, the strength of hot-pressed silicon nitride showed three timedependent regions of behavior: (1) crack healing, leading to strength enhancement; (2) pit formation, a corrosion reaction which changes the flaw population to a more uniform size distribution; and (3) creep, whereby extensive cavitation, grain deformation, and diffusional grain boundary sliding result in plastic deformation and fracture from extensive flawed regions. These regions were identified from microscopic observations and from the plots of constant failure probability vs time on a strength degradation map. This is a new form of data presentation for silicon nitride that displays the time dependence of strength according to the failure mechanisms.

\section{ACKNOWLEDGMENT}

This study was supported by the Department of Energy, Office of Coal Utilization, under contract EA-77A01-6010. The authors would like to thank G. G. Garrett, M. Maurer, C. L. McDaniel, W. Willard, and J. M. Thomas for their assistance in taking data and modifying equipment. 


\section{REFERENCES}

[1] R. W. Davidge, A. G. Evans, D. Gilling, and P. R. Wilyman, Oxidation of reaction sintered silicon nitride and effects on strength, Special Ceramics 5: 329 (1972).

[2] R. Kossowsky, creep and fatigue of $\mathrm{Si}_{3} \mathrm{~N}_{4}$ as related to microstructures in Ceramics for High Performance Applications II. J. J. Burke, A. E. Gorum, and R. N. Katz, eds., Brook Hill, Mass. 1974.

[3] S. M. Wiederhorn and N. J. Tighe, Proof-testing of hot-pressed silicon nitride, J. Mat. Sci. 13: 1781 (1978).

[4] N. J. Tighe, The structure of slow-crack interfaces in silicon nitride, J. Mat. Sci. 13: 1455 (1978).

[5] A. G. Evans and S. M. Wiederhorn, Crack propagation and failure prediction in silicon nitride at elevated temperatures, J. Mat. Sci. 9: 270 (1974).

[6] E. R. Fuller, S. M. Wiederhorn, J. E. Ritter, and P. B. Oates, Proof testing of ceramics, Part 2. Theory, J. Mat. Sci. 15: 2282 (1980).

[7] J. E. Ritter, S. M. Wiederhorn, N. J. Tighe, and E. R. Fuller, Applications of fracture mechanics in assuring against fatigue failure of ceramic components, in Ceramics for High Performance Applications II. Reliability, E. M. Lenoe, R. N. Katz, and J. J. Burke, eds., Plenum Press, New York, 1981.

[8] N. J. Tighe and S. M. Wiederhorn, Fracture of brittle materials at high temperature, Technical Report AFML. TR-78-33, 1977.

[9] W. Weibul1, A statistical distribution function of wide applicability, J. Appl. Mech., 18: 293 (1951).

[10] S. M. Wiederhorn, A probabilistic framework for structural design, this volume.

[11] M. F. Ashby, A first report on deformation mechanism maps, Acta Meta11., 20: 887 (1972).

[12] C. A. Johnson, Fracture statistics in design and application, Report No. 79CRP212, G.E. Technical Information Series (1979). 
[13] J. J. Mecholsky and S. W. Freiman, Determination of fracture mechanics parameters through fractographic analysis of ceramics in ASTM, Special Technical Publication 678, 1980.

[14] R. W. Rice, S. W. Freiman, J. J. Mecholsky, R. Ruh, and Y. Harada, Fractography of $\mathrm{Si}_{3} \mathrm{~N}_{4}$ and $\mathrm{SiC}$, in Ceramics for High Performance Applications II. J. J. Burke, A. E. Gorum, and R. N. Katz, eds., Brook Hi11, Mass. 1974.

[15] A. G. Evans and W. Blumenthal, High temperature failure in ceramics, this volume. 
EFFECTS OF OXIDATION ON THE SURFACE AND NEAR-SURFACE STRUCTURE OF SILICON NITRIDE

Nancy J. Tighe

National Bureau of Standards

Washington, DC 20234

To be published in:

Journal of Materials Science 

EFFECTS OF OXIDATION ON THE SURFACE AND NEAR-SURFACE STRUCTURE OF SILICON NITRIDE

\author{
Nancy J. Tighe \\ National Bureau of Standards \\ Washington, D.C. 20234
}

\title{
INTRODUCTION
}

Silicon nitride is being evaluated for special components in diesel and turbine engines because their use offers the possibility of higher engine operating temperatures with greater efficiency and less pollution. The components will be exposed to temperatures above $1000{ }^{\circ} \mathrm{C}$ in engine fuel atmospheres which are slightly oxidizing. Therefore, it is necessary to consider the effects of an oxidizing atmosphere on component strength and durability. In the course of an extensive program concerned with proof testing to access reliability of structural ceramics, we have shown that the strength changes that occur during heating in an oxidizing atmosphere result because the flaw population (by which strength is defined) changes during the exposure to the testing conditions $[1,2]$.

The flaw population in as-ground silicon nitride specimens includes cracks produced during surface grinding; and, internal particles and pores produced during powder processing and hot-pressing. This flaw population can change during exposure by: (a) flaw healing whereby the size and effectiveness of initial flaws are reduced; and, (b) flaw generation whereby new flaws such as surface pits, grain boundary cracks and internal oxide inclusions are produced. The new flaws have more unpredictable effects on the strength distribution because they are produced in a time and stress dependent manner and thus are changing continuously.

Additionally, billets produced with the same nominal composition showed measurable differences in strength distribution after high temperature exposures. For example, the Weibull plots of strength distribution in Fig. 1 show that specimens from billets $A$ and $B$ have similar strength distributions after $1 / 2$ 
hr. at $1200{ }^{\circ} \mathrm{C}$. After heating for $100 \mathrm{hr}$. billet $\mathrm{A}$ specimens are weaker and billet $B$ specimens are stronger than they were after the $1 / 2 \mathrm{hr}$. tests. In these test specimens, the initial ground surface was covered in $1 / 2 \mathrm{hr}$. at $1200{ }^{\circ} \mathrm{C}$ by amorphous and crystalline silica. After $100 \mathrm{hrs}$, the oxide scale was $20 \mathrm{\mu m}$ thick and was composed of $\mathrm{Si}_{2} \mathrm{~N}_{2} \mathrm{O}, \mathrm{SiO}_{2}, \mathrm{MgSiO}_{3}$ and amorphous phases.

In order to understand the strength and microstructural changes that are produced during oxidation, it is necessary to examine the oxide scale, the oxide/silicon nitride interface and the silicon nitride below the oxide/matrix interface. In the present study, these three interfacial layers were removed and analyzed using transmission electron microscopy, light microscopy and $x$-ray energy analysis and diffraction. Oxide scales were produced on hotpressed silicon nitride samples by heating in air at $1000^{\circ} \mathrm{C}, 1200{ }^{\circ} \mathrm{C}$, and $1400{ }^{\circ} \mathrm{C}$ for $1 / 2$ to $1000 \mathrm{hr}$. The phases in the oxide scale were found to occur in layers that were ordered according to the phase diagrams for the oxide mixtures $[3,4,5]$. Crystalline and amorphous phases were present in all specimens examined. The oxynitride and amorphous phases are present in as-pressed billets at triple junctions and along grain boundaries [6-8]. The elements in the amorphous phases have been identified using electron energy loss analysis (EELS) and energy dispersive $x$-ray analysis (EDAX) [9] however (EELS) instrument was not available for the present study. In this paper, the phases found in the oxide scales are characterized and the relationships between the oxide scale, the oxide/matrix interface and the mechanical properties are discussed.

\section{EXPERIMENTAL PROCEDURE}

Specimens examined during this study were made from billets of hot-pressed magnesia-doped $\mathrm{Si}_{3} \mathrm{~N}_{4}$ designated $\mathrm{HS} 130$ and NC132. Specimens thin enough for examination in a $200 \mathrm{kV}$ electron microscope were made from oxidized specimens by sectioning them parallel to the oxide/silicon nitride interface, grinding the section to include the desired portion of the oxide layer, polishing the thin section to show the oxide phases, and then ion-thinning until the desired area was electron transparent.

The oxidation treatments were carried out on thin foil specimens as well as on bulk samples. Small specimens were held vertically in a silicon nitride 
boat and larger bars or plates were supported at the ends on silicon nitride or silicon carbide plattens. Thus, there was no direct contact with an oxide ceramic or a metal foil which would cause an undesirable chemical reaction. Specimens were weighed and measured before and after oxidation in order to record the oxide scale growth. Specimens were oxidized by heating in air at $1000{ }^{\circ} \mathrm{C}, 1200{ }^{\circ} \mathrm{C}$, and $1400{ }^{\circ} \mathrm{C}$ for times of $1 / 2$ to $1000 \mathrm{hr}$, i.e. using times appropriate to the mechanical test conditions. The oxide scale on some specimens was dissolved in $\mathrm{HF}+\mathrm{H}_{2} \mathrm{SO}_{4}$ in order to establish the depth of oxide penetration into the matrix.

RESULTS AND DISCUSSION

STRUCTURE OF THE OXIDE SCALE

Examination of the surface and cross sections of oxidized specimens showed that the oxide scale formed in layers that varied in composition and in crystal structure depending on the temperature and time of exposure. The different phases could be distinguished readily by light microscopy, but not so readily by scanning electron microscopy. Plates $1 \mathrm{~mm}$ thick which were oxidized at $1400{ }^{\circ} \mathrm{C}$ sagged as a result of the exposure indicating that creep and plastic deformation had taken place. Edge cracks in bent specimens were filled with oxide and could be seen easily in the polished sections. The oxide scale on specimens that were heated cyclically at $1400{ }^{\circ} \mathrm{C}$ showed globules of silicate which was considered evidence for melting (Fig. 2). Such melting is attributed to the gradual change in composition of the oxide surface which enhanced the oxidation rate compared with continuously heated samples.

Silicon Oxynitride-Si ${ }_{2} \mathrm{~N}_{20}[10,11]$. When polished sections are examined in the light microscope, the oxynitride can be distinguished from the silicon nitride matrix by its darker grey color which results from the difference in reflectivity $(r)$, and index of refraction $(n): \mathrm{Si}_{3} \mathrm{~N}_{4} r=12.2, n=2.1 ; \mathrm{Si}_{2} \mathrm{~N}_{2} \mathrm{O} r=8.5, n=1.82$ [12]. In the light micrograph of Fig. 2d, spherical oxide nodules are visible below the matrix/oxide interface. The smallest nodules are oxynitride, and in the center of the larger nodules the silicate phase is visible; thus, indicating 

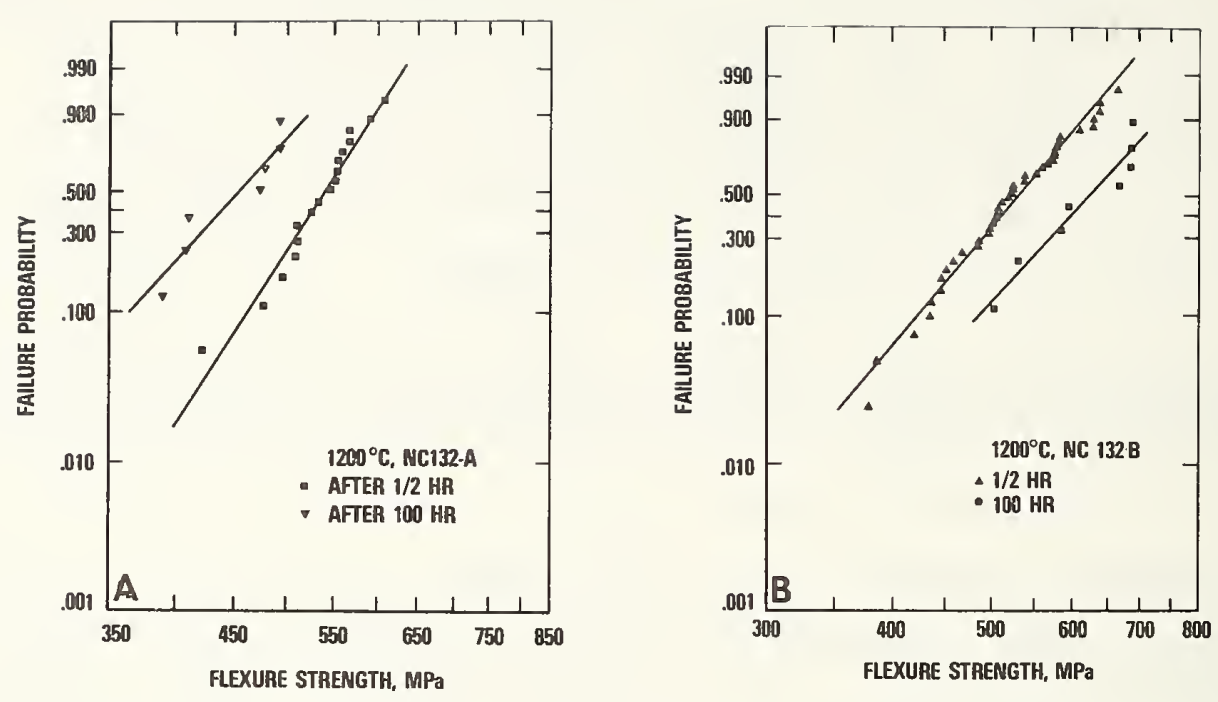

Fig. 1. Plots showing strength distribution obtained at $1200{ }^{\circ} \mathrm{C}$ for $\mathrm{Si}_{3} \mathrm{~N}_{4}$ after heating $1 / 2 \mathrm{hr}$. and $100 \mathrm{hr}$. at $1200^{\circ} \mathrm{C}$ [2].
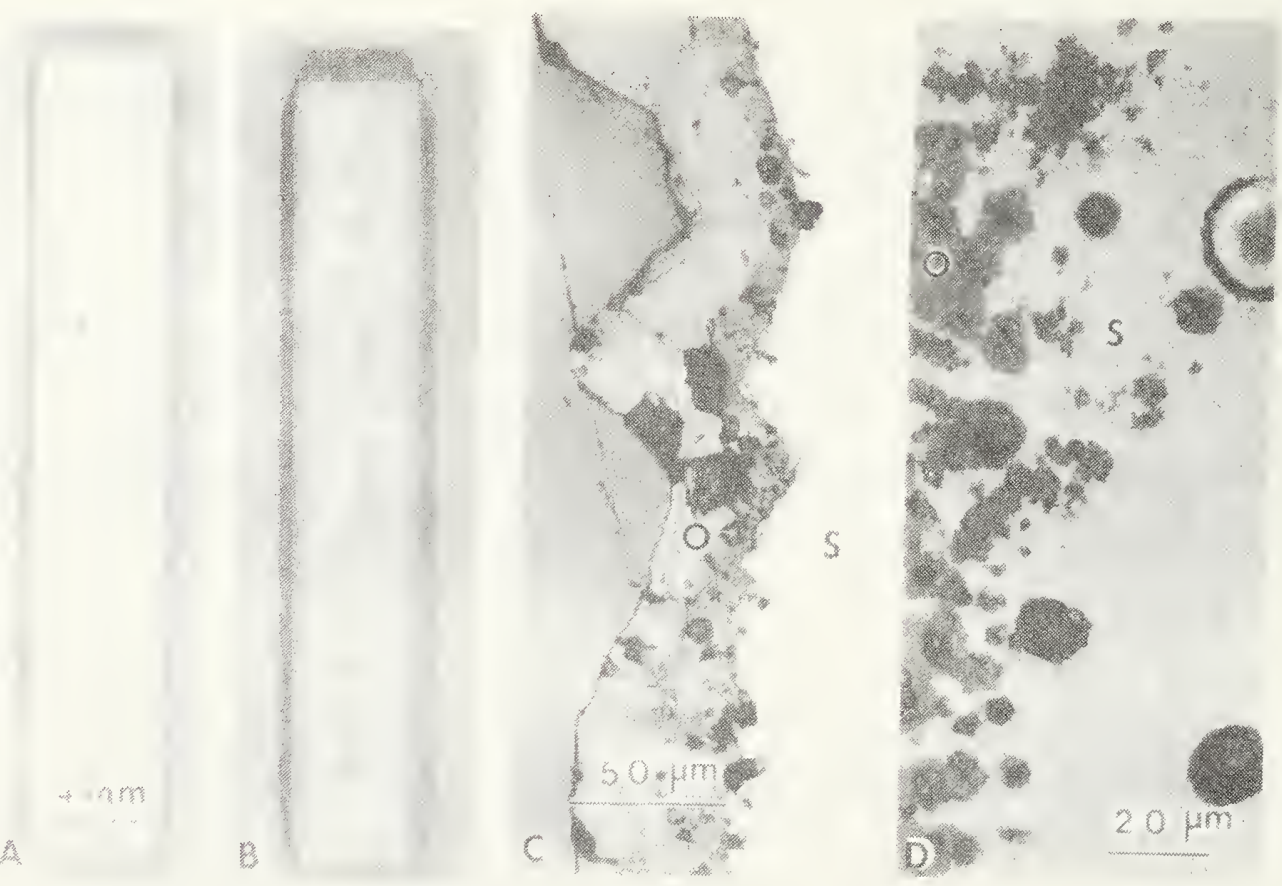

Fig. 2. Hot-pressed silicon nitride samples which were oxidized at $1400{ }^{\circ} \mathrm{C}$ (A) specimen heated continuously for $100 \mathrm{hr}$., (B) specimen heated and cooled to room temperature several times during $96 \mathrm{hr}$., (C) polished section of cyclically heated specimen note thickness variations in oxide scale -0 - and in $\mathrm{Si}_{3} \mathrm{~N}_{4}-\mathrm{S}-$. (D) nodules of $\mathrm{Si}_{2} \mathrm{~N}_{2} \mathrm{O}$ below the primary oxide-matrix interface in spec. $\mathrm{B}$. 
a more complete oxidation reaction. The position of the nodules below the reaction interface is strong evidence for significant diffusion of oxygen into the matrix at $1400{ }^{\circ} \mathrm{C}$.

The electron micrographs in Fig. $3 a, b$ show the structure of the oxynitride phase in a thin foil specimen prepared from a section similar to $m-m$ in Fig. 2c. The lower magnification picture of Fig. 3a shows two oxynitride grains with a region of silicon nitride grains between them. In Fig. 36 the faults, pores and inclusions within one of the oxynitride grains are imaged. It is apparent that the initial silicon nitride grains were consumed by the growing oxynitride.

Cristobalite- $\mathrm{BSiO}_{2}$. Beta-cristobalite was found along the silicon nitride interfaces in specimens oxidized at $1000{ }^{\circ} \mathrm{C}$ and throughout the oxide scale in specimens oxidized at $1400^{\circ} \mathrm{C}$. The cristobalite was found in quenched samples as well as in samples that were oxidized at $1000{ }^{\circ} \mathrm{C}$ and $1200{ }^{\circ} \mathrm{C}$ in a special high temperature $x$-ray furnace. The phase coexists with an amorphous phase which appears to be silica from its diffraction pattern.

Figure 4 shows $\beta$-cristobalite which was produced in a thin foil by heating for one hour at $1000{ }^{\circ} \mathrm{C}$. The oxide grains, which were contained within the amorphous layer, were identified by their diffraction patterns. This figure demonstrates the major difficulty associated with examining $\mathrm{SiO}_{2}$ in an electron microscope, namely the vitrification that occurs rather quickly [13]. As shown in Fig. 4, the $\beta$-cristobalite transformed to a disordered $\alpha$-cristobalite which then transformed to amorphous silica without changing shape. A similar decomposition occurred in all of the samples regardless of the oxidation conditions. The diffraction pattern of the transformed amorphous silica was used as a standard pattern for silica glass.

Magnesium Silicate-MgSiO ${ }_{3}$. The magnesium silicate phase, enstatite, was found in sections of specimens that were oxidized at $1200{ }^{\circ} \mathrm{C}$ and $1400{ }^{\circ} \mathrm{C}$. The enstatite was found to coexist with $\beta$-cristobalite forming a well-sintered layer. Figure 5 shows an example of the layer morphology. In this figure the $\beta$-cristobalite has vitrified as expected, while the enstatite remained unchanged during long time irradiation. The enstatite grains were usually faulted and had a microstructure similar to the natural mineral [14]. 

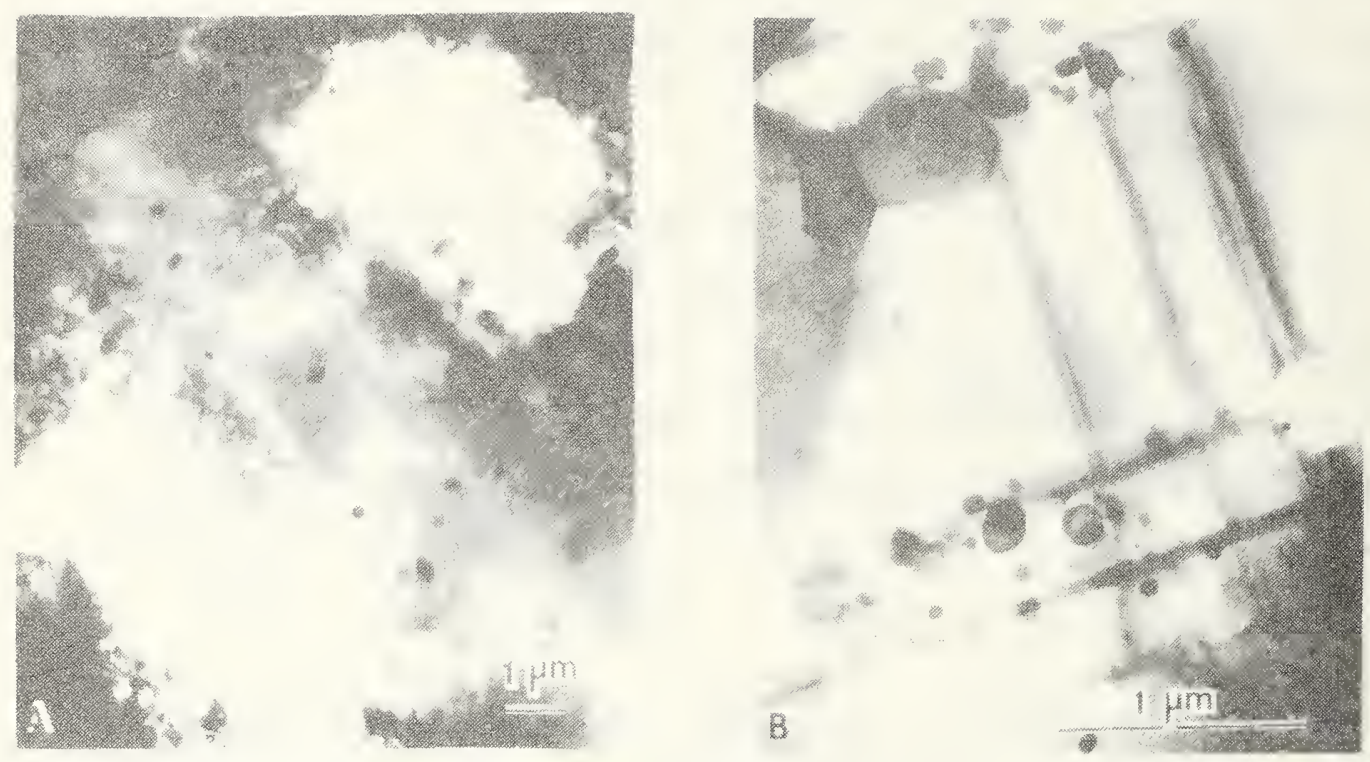

Fig. 3. Electron micrograph of sections from specimen heated $264 \mathrm{hr}$. at $1000{ }^{\circ} \mathrm{C}$ showing (A) $2 \mathrm{Si}_{2} \mathrm{~N}_{2} \mathrm{O}$ grains within the $\mathrm{Si}_{3} \mathrm{~N}_{4}$ matrix, (B) enlargement of oxynitride grain showing faults, pores and precipitates.

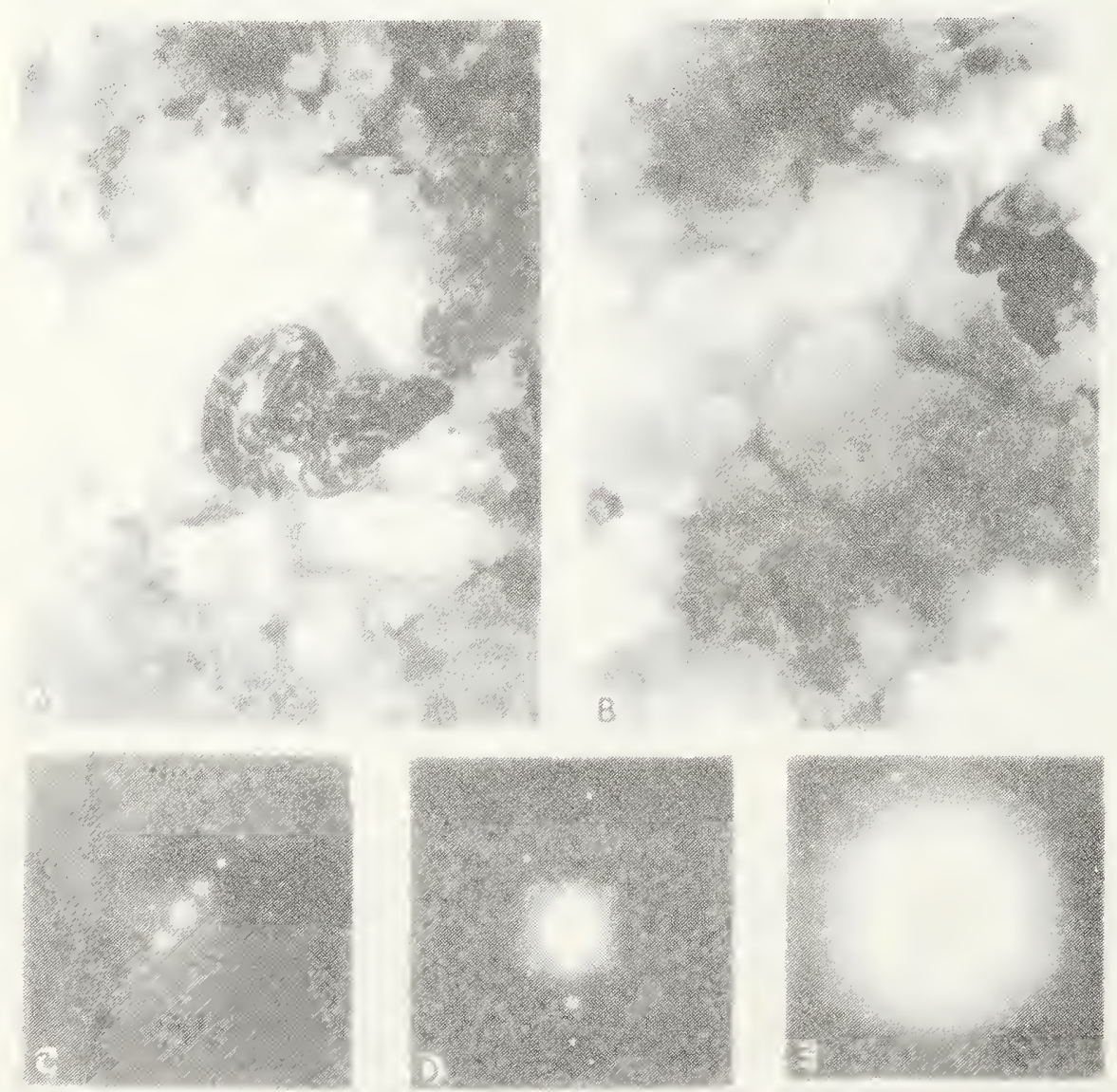

Fig. 4. Thinned $\mathrm{Si}_{3} \mathrm{~N}_{4}$ foil after heating $1 \mathrm{hr}$. at $1000{ }^{\circ} \mathrm{C}$, thin area oxidized completely to cristobaitite and glass; (A) $\mathrm{SiO}_{2}$ grains, (B) vitrified $\mathrm{SiO}_{2},(C, D, E)$ diffraction patterns of the transformation $\mathrm{BSiO}_{2} \rightarrow \alpha \mathrm{SiO}_{2} \rightarrow$ amorphous $\mathrm{SiO}_{2}$. 
Both cristobalite and enstatite can be produced by devitrification of magnesium silicate glass at $1400{ }^{\circ} \mathrm{C}$ [5]. At $1400{ }^{\circ} \mathrm{C}$ the stable crystalline phase is protoenstatite while clinoenstatite forms on cooling below $1000{ }^{\circ} \mathrm{C}$. Enstatite belongs to the mineral class of pyroxenes which vary in structure according to the impurities in theil. The element analysis shows that the magnesium silicate layer contains $\mathrm{Fe}, \mathrm{Ca}, \mathrm{Al}$ and other impurities commonly found in hot-pressed silicon nitride. The presence of these impurities in the scale in quantities sufficient to form varients of the pyroxenes is evidence for diffusion from the matrix to the oxide scale. In sampling specimens from the mechanical test specimens, it was noted that the occurrence of enstatite coincided with the rapid degradation of strength and the rapid dissolution of the ground surface $[1,2]$.

STRUCTURE OF THE DIFFUSION REACTION ZONE

The changes in strength of silicon nitride as a result of oxidation must be considered with respect to changes produced in the matrix near the oxide scale interface. Because of the overwhelming evidence for diffusion from the matrix to the outer oxide interface in this paper and in others $[3,4,6]$, this region is termed the diffusion reaction zone. The microstructure of this zone was examined using thin sections of specimens oxidized at $1200{ }^{\circ} \mathrm{C}$ for $>200 \mathrm{hr}$. and at $1400{ }^{\circ} \mathrm{C}$ for $\mathrm{I}$ and $24 \mathrm{hr}$.

Oxidation in the diffusion reaction zone appeared to initiate at grain boundaries as evidenced by either porosity or by thickening of a grain boundary phase. Figure 6 shows a pore between grains in a sample oxidized at $1400{ }^{\circ} \mathrm{C}$. An example of thickening of the oxide phase between grain boundaries is shown in Fig. 7 where the breadth of the phase is indicated by the moire fringe pattern. At this temperature, the evidence for creep and plastic deformation in the bulk specimens was shown by the extensive dislocation interactions in the diffusion reaction zone. There is a significant increase in the occurrence of grain boundary dislocations, sub-boundaries, and dislocation interactions with inciusions as in Figs. 6 and 7b. Rapid growth of oxide at the grain boundaries can produce considerable deformation; and, this extended phase can fracture on cooling to produce extensive grdin boundary cracking and a new flaw population. 


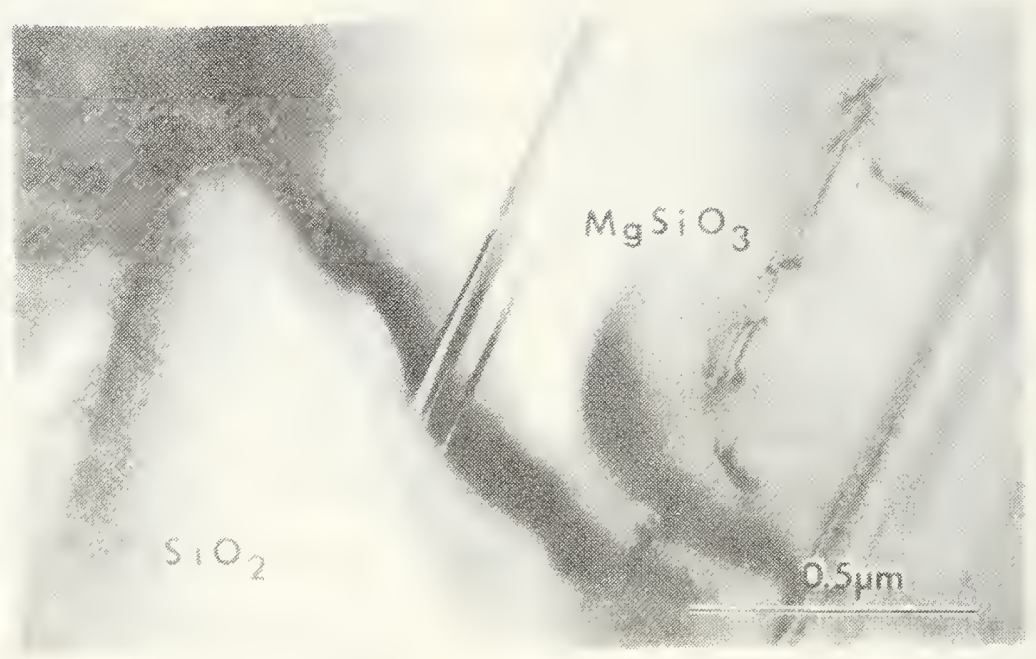

Fig. 5. Oxide scale from bulk specimen heated at $1400{ }^{\circ} \mathrm{C}$ showing grains of $\mathrm{SiO}_{2}$ and $\mathrm{MgSiO}_{3}$, note the $\mathrm{SiO}_{2}$ grain has vitrified.

Fig. 6. Silicon nitride grains in specimen heated $24 \mathrm{hr}$. at $1400^{\circ} \mathrm{C}$, large pore is seen along grain boundary (arrowed). 
Evidence for nucleation and growth of $\mathrm{Si}_{2} \mathrm{~N}_{2} \mathrm{O}$ within the silicon nitride grains is shown in Fig. 8. This foil was made from a specimen that was oxidized for $24 \mathrm{hr}$. at $1000{ }^{\circ} \mathrm{C}$ and had an oxide scale composed of amorphous silica and $\beta$-cristobalite. The presence of such plates in the matrix grains could reduce fracture toughness by providing easy intragranular fracture paths along the fault planes.

Oxidation at the well-known inclusions from the WC grinding media can lead to the formation of an oxide filled pit in the matrix and a mound or depression in the oxide scale. Such pits were shown to be active fracture sites in specimens broken at $1200{ }^{\circ} \mathrm{C}$; and the oxide scale at the pit was found to have a high Fe content [1]. The grinding particle inclusions seen in foils made from as-received specimens, as shown in Fig. 9, are usually polyhedral and range in size from a few nanometers to a few micrometers. Energy dispersive analysis shows $\mathrm{Fe}, \mathrm{Cr}, \mathrm{Co}, \mathrm{Al}$, and $\mathrm{W}$ from the $\mathrm{WC}$ particles and the metal alloy binder. In oxidized specimens these inclusions may be polyhedral or spherical and examples are shown in Fig. 10. The inclusion in Fig. 10a is surrounded by an amorphous film and is presumed to show an early oxidation reaction which when complete would produce an oxide-filled pit. The spherical particles in Fig. 10b show a high $\mathrm{Fe}$ and $\mathrm{Cr}$ but not $W$ content. The different morphology and composition indicate possible melting during the exposure at $1400{ }^{\circ} \mathrm{C}$. The oxide pits affect the strength in a time dependant mechanism because they require an incubation time to be produced. The distribution of the grinding particle inclusions varies somewhat from billet to billet hence, the growth of the oxide pits will vary to change the flaw population.

SIGNIFICANCE OF THE INTERFACIAL ANALYSIS

The results presented here represent the starting point for further analysis of the relationship between microstructure and high temperature mechanical properties of silicon nitride. Because this ceramic oxdizes its high temperature behavior as a structural material must be defined in terms of its oxidation behavior. 


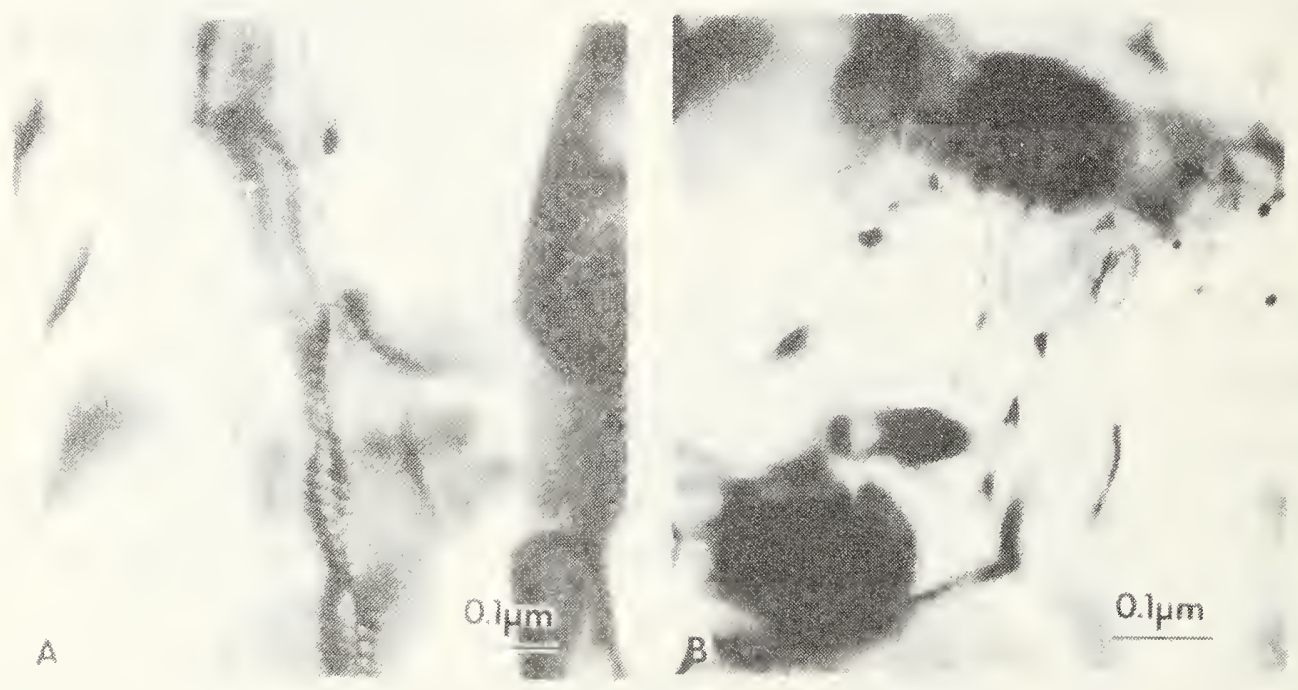

Fig. 7. Section from bar heated cyclically for $96 \mathrm{hr}$. at $1400^{\circ} \mathrm{C}$ showing: (A) Silicon nitride grains in the diffusion reaction zone, moiré fringes along the boundary show position of the growing oxide film. (B) Dislocation interactions with inclusions near area in (A).

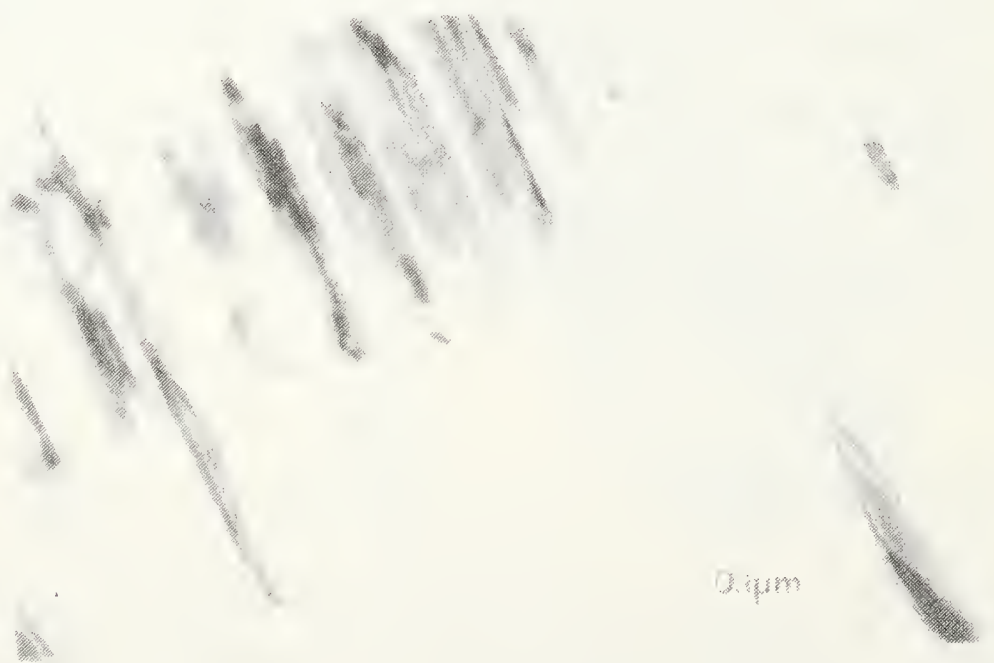

Fig. 8. Grain of $\mathrm{Si}_{3} \mathrm{~N}_{4}$ containing plates of $\mathrm{Si}_{2} \mathrm{~N}_{2} \mathrm{O}$ in the diffusion reaction zone of a specimen oxidized $24 \mathrm{hr}$. at $1000^{\circ} \mathrm{C}$. 

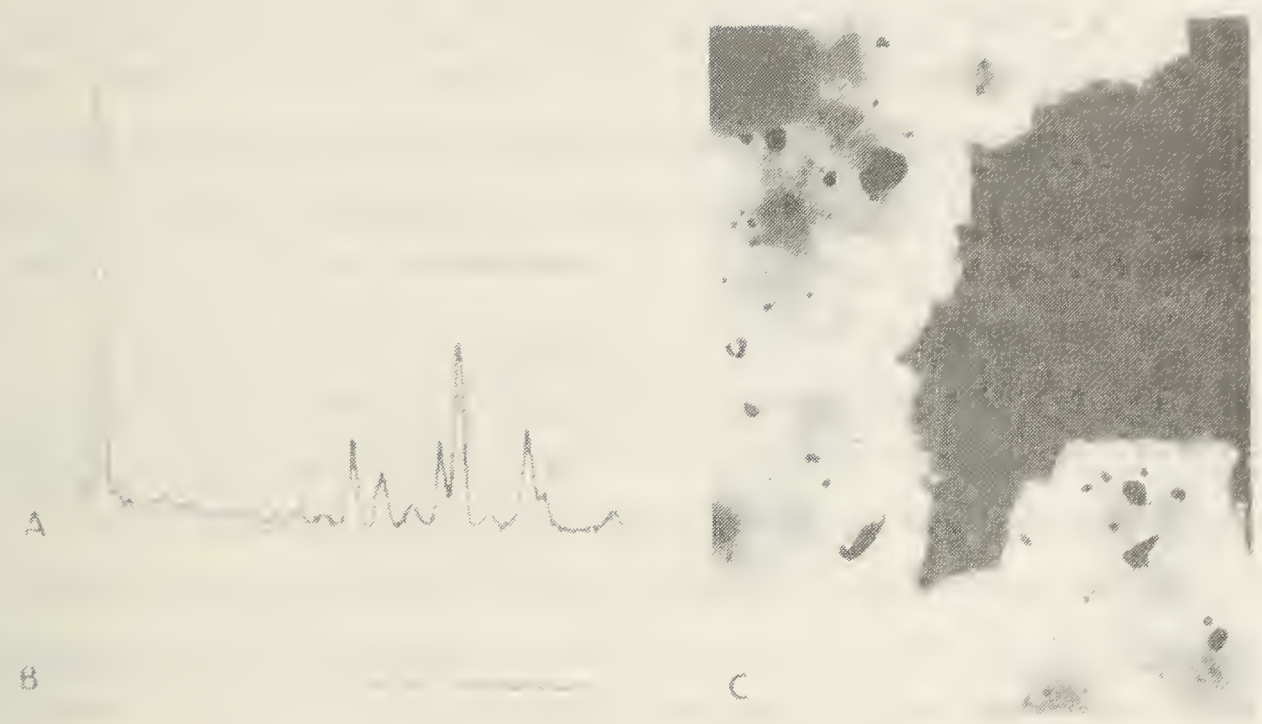

Fig. 9. Inclusions in hot-pressed $\mathrm{Mg}$-doped $\mathrm{Si}_{3} \mathrm{~N}_{4}$ (C) dark field micrograph showing distribution and size, energy dispersive analysis of particles (A) and matrix (B).
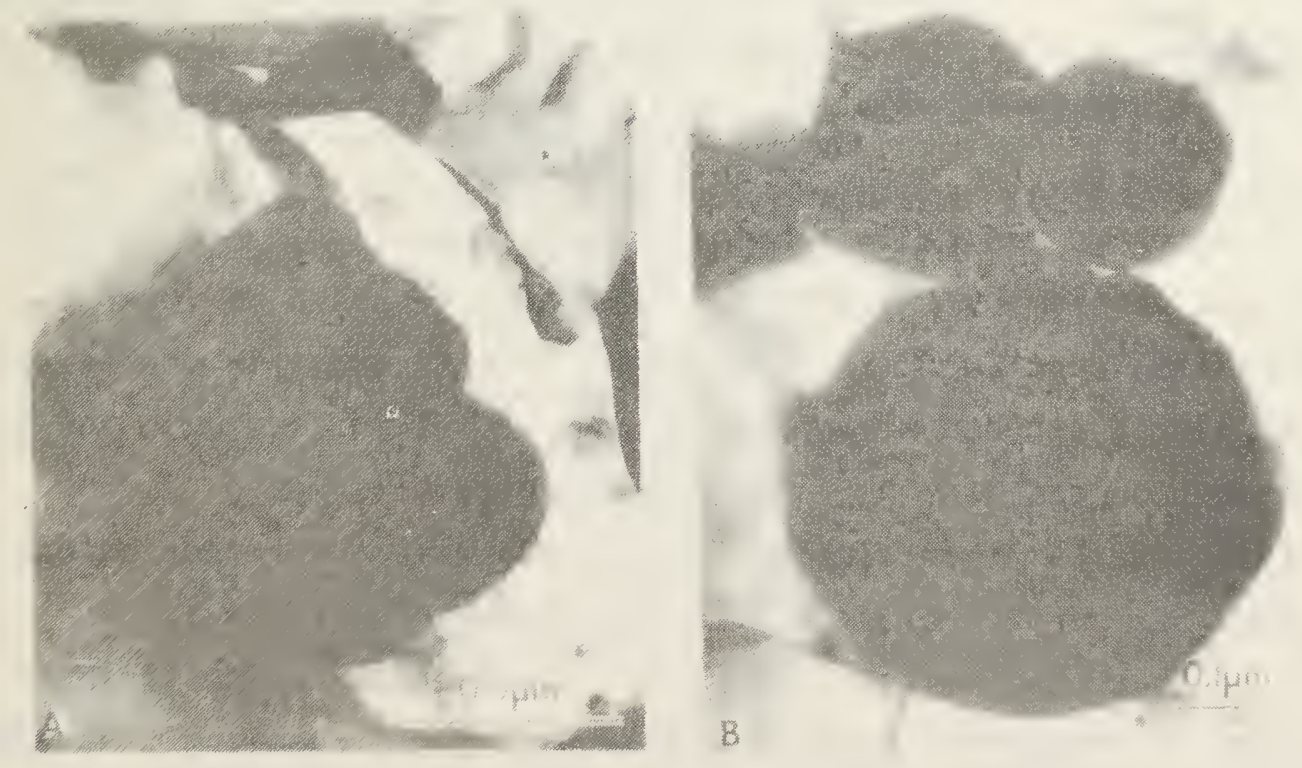

Fig. 10. Inclusions in $\mathrm{Si}_{3} \mathrm{~N}_{4}$ specimen heated at $1400{ }^{\circ} \mathrm{C}$ (A) in $1 \mathrm{hr}$. inclusion is surrounded by porous and amorphous phase, indicating that oxidation has started. (B) After $96 \mathrm{hr}$. of cyclic heating, inclusions are spherical and show no W. 
The effect of flaws, such as machining cracks which intersect the surface, on the strength can be changed by oxidation which blunts them or shortens them. When the matrix is consumed by the growing oxide as shown in Fig. 2 then the crack size is reduced and the strength is increased. The time frame for such crack healing is related to the transformation of oxide scale from oxynitride and silica to the silica and silicate. A sharp crack can be blunted when the interfacial matrix grains oxidize. A blunt crack requires a higher stress intensity factor for propogation which leads to a higher strength. Thus either of these two effects can cause a strengthening. We have shown here that in the billets studied oxidation can change the strength by reducing the effectiveness of old flaws and by generating new flaws. The specific causes of billet to billet variation in strength and oxidation behavior have not been determined. The oxide scales are similar in composition but have grown at considerably different rates apparently as a result of minor impurity differences.

The interaction of the different oxide phases with each other and with the silicon nitride matrix is time and temperature dependent. As long as only silicon oxynitride and crystalline and amorphous silica cover the exposed surfaces, the oxidation rate is slow and the oxide scale is protective. Diffusion of oxygen through the oxide scale is then rate controlling. When sufficient diffusion of $\mathrm{Mg}$ and $\mathrm{Ca}$ impurities from the matrix has occurred to permit growth of the pyroxene phase then the oxidation reaction can change rapidly. The diffusion reaction zone illustrated in this paper is more complex than the original matrix structure; and, more examples taken from oxidized and deformed samples must be examined to fully characterize this zone. Recent experiments with sialons (silicon-alumina-oxynitride) have shown that oxidation at $1400{ }^{\circ} \mathrm{C}$ for $1000 \mathrm{hr}$. can be beneficial to the strength as a result of diffusional changes in the microstructure [15]. Specimens of magnesia-doped hot-pressed silicon nitride which have undergone such long annealing treatments during static fatigue tests show some strengthening but these specimens have not been characterized completely to identify the sources of the strengthening. 
CONCLUSIONS

1) The oxide scale on magnesia-doped hot-pressed $\mathrm{Si}_{3} \mathrm{~N}_{4}$ forms in layers composed of amorphous and crystalline $\mathrm{SiO}_{2}, \mathrm{Si}_{2} \mathrm{~N}_{2} \mathrm{O}$, and $\mathrm{MgSiO}_{3}\left(\mathrm{MgO} \cdot \mathrm{SiO}_{2}\right)$.

2) A diffusion reaction zone in the $\mathrm{Si}_{3} \mathrm{~N}_{4}$ matrix is produced during oxidation; and, structure changes in this zone affect strength.

3) Flaw healing and flaw generation occur as a consequence of the growth of oxide phases at and below the $\mathrm{Si}_{3} \mathrm{~N}_{4}$ ground surfaces during heating at temperatures $\geqslant 1000{ }^{\circ} \mathrm{C}$.

\section{REFERENCES}

1. S. M. Wiederhorn and N. J. Tighe, Proof-Testing of Hot-Pressed Silicon Nitride, J. Mat. Sci. 13:1781 (1978).

2. S. M. Wiederhorn and N. J. Tighe, Effect of Flaw Generation on Proof Testing, MCIC Report, March 1978 p. 689.

3. N. J. Tighe, Microstructure of Oxidized Silicon Nitride, Proc. EMSA p. 470-71 (1974) Claitor Pub1. Baton Rouge.

4. S. C. Singhal, Thermodynamics and Kinetics of Oxidation of Hot-Pressed Silicon Nitride, J. Mat. Sci. 11:500 (1976).

5. L. Atlas, The Polymorphism of $\mathrm{MgSiO}_{3}$ and Solid-State Equilibria in the System $\mathrm{MgSiO}_{3}-\mathrm{CaMgSi}_{2} \mathrm{O}_{6}$, J. Geol. 60:125 (1952).

6. D. R. Clarke and G. Thomas, Grain Boundary Phases in Hot-Pressed MgO Fluxed Silicon Nitride, J. Amer. Ceram. Soc. 60:491 (1977).

7. A. H. Heuer, V. Lou, L. Ogbugji, and T. E. Mitchell, Lattice Resolution Studies of Engineering Ceramics: $\mathrm{SiC}$ and $\mathrm{Si}_{3} \mathrm{~N}_{4}$, J. Micros. Spect. Electron 2: 475 (1977).

8. 0. L. Krivanek, T. M. Shaw, and G. Thomas, Imaging of Intergranular Phases by HREM, J. Appl Phys. 50:4223 (1979).

9. 0. L. Krivanek, Electron Energy Loss Spectrometer, Proc. EMSA (1980) Claitor Publ. Baton Rouge.

10. I. Idrestedt and C. Brosset, Structure of $\mathrm{Si}_{2} \mathrm{~N}_{2} \mathrm{O}$, Acta Chem. Scand. 18: 1879 (1964). 
11. C. A. Anderson, K. Keil, and B. Mason, Silicon Oxynitride: A Meteoritic Minera], Sci. 146:256 (1964).

12. D. Taylor, Reflected Light Microscopy of Silicon Nitride and Oxynitride.

13. N. J. Tighe and J. M. Christie, Deformation Structures in Quartz Rocks, Proc. EMSA p. 60-61 (1969) Claitor Pub7. Baton Rouge.

14. P. E. Champness and G. W. Lorimer, Precipitation in an Orthopyroxene, J. Mat. Sci. 8:467 (1973).

15. M. H. Lewis and P. Barnard, Oxidation Mechanisms in Si-Al-O-N Ceramics, J. Mat. Sci. 15:443 (1980).

\section{Acknow edgments}

This work was supported in part by the Office of Coal Utilization, Div. of Heat Engines and Heat Recovery, Department of Energy Contract EA77-A01-6010 Task A086. Figure 9 was taken with the STEM instrument at M.I.T. by A. Garrett Reed. 
1. PUBLICATION OR REPORT NO.

NBSIR $81-2445$
2. Performing Organ. Report Nod 3. Publication Date

December 1981

BIBLIOGRAPHIC DATA

SHEET (See instructions)

4. TITLE AND SUBTITLE

Application of Proof Testing to Brittle Materials at High Temperatures

5. $\operatorname{AUTHOR}(S)$

Nancy J. Tighe and Sheldon M. Wiederhorn

6. PERFORMING ORGANIZATION (If joint or other than NBS, see instructions)

7. Contract/Grant No.

NATIONAL BUREAU OF STANDARDS

DEPARTMENT OF COMMERCE

WASHINGTON, D.C. 20234

8. Type of Report \& Period Covered

9. SPONSORING ORGANIZATION NAME AND COMPLETE ADDRESS (Street, City, State, ZIP)

Department of Energy

Washington, DC 20545

10. SUPPLEMENTARY NOTES

Document describes a computer program; SF-185, FIPS Software Summary, is attached.

11. ABSTRACT (A 200-word or less factual summary of most significant information. If document includes a significant bibliography or literature survey, mention it here)

The report contains the publications prepared during the contract period. The publications concern the theories of proof testing for assuring reliability and present experimental results obtained on silicon nitride tested at $1200^{\circ} \mathrm{C}$. The important conclusion from the research is that the flow population which caúses failure changes during exposure and produces new population. A approach which includes dynamic flow population was developed and is included in the report. The experimental data is presented in the form of a map which displays strength vs. time under load.

12. KEY WORDS (Six to twelve entries; alphabetical order; capitalize only proper names; and separate key words by semicolons)

Deformation maps; High Zemperatures; Proof testing; Reliability; Silicon nitride; Structural ceramics

13. AVAILABILITY

XX Unlimited

$\square$ For Official Distribution. Do Not Release to NTIS

$\square$ Order From Superintendent of Documents, U.S. Government Printing Office, Washington, D.C. 20402.

XXX Order From National Technical Information Service (NTIS), Springfield, VA. $2216 I$
14. NO. OF

PRINTED PAGES

201

15. Price

$\$ 18.00$ 


